\section{CIHM}

Microfiche Series

\section{ICMH \\ Collection de microfiches (monographies)}

Canadian Institute for Historical Microreproductions / Institut canadien de microreproductions historiques
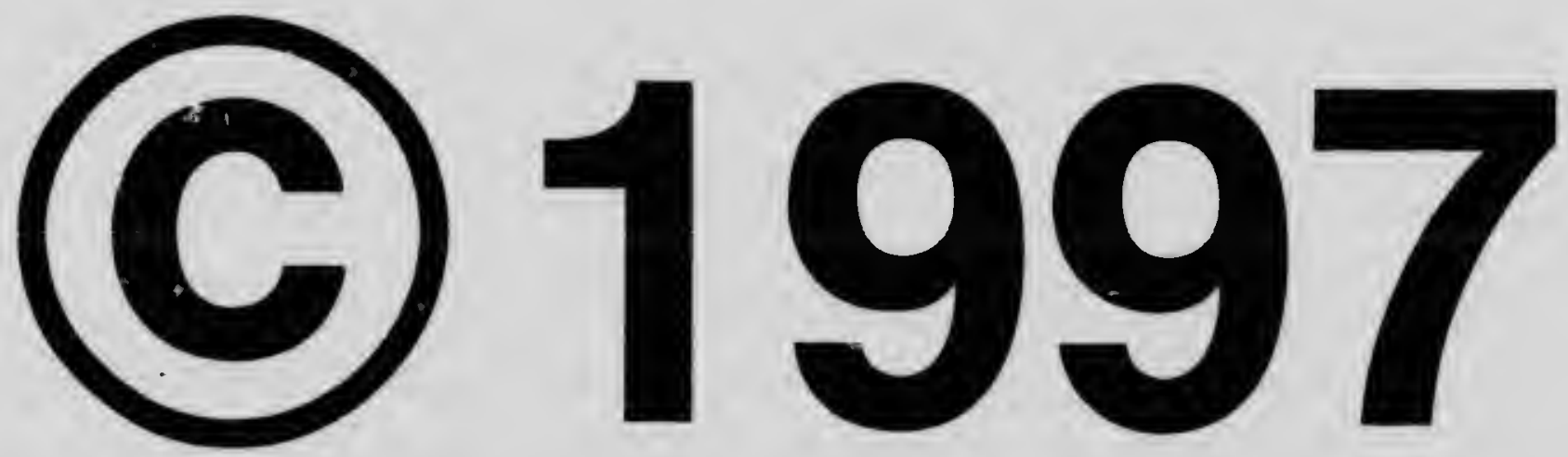


\section{Technical and Bibliographic Notes / Notes techniques et bibliographiques}

The Instltute has attempted to obtaln the best original copy available for filming. Features of this copy which may be bibliographically unlque, which may alter any of the images in the reproduction, or which may slgniflcantly change the usual method of filming are checked below.

\section{Coloured covers I}

Couverture de couleur

\section{Covers damaged /}

Couverture endommagée

Covers restored and/or laminated /

Couverture restaurée et/ou pelliculée

Cover title missing / Le titre de couverture manque

Coloured maps / Cartes géographiques en couleur

Coloured ink (i.e. other than blue or black) /

Encre de couleur (i.e. autre que bleue ou noire)

Coloured plates and/or illustrations /

Planches et/ou illustrations en couleur

Bound with other material /

Relié avec d'autres documents

Only edition available /

Seule édition disponible

Tight binding may cause shadows or distortion along interior margin / La reliure serrée peut causer de l'ombre ou de la distorsion le long de la marge intérieure.

Blank leaves added during restorations may appear within the text. Whenever possible, these have been omitted from filming / II se peut que certaines pages blanches ajcutées lors d'une restauration apparaissent dans le texte, mais, lorsque cela était possible, ces pages n'ont pas été filmées.

Additional comments /

Commentaires supplémentaires:
L'Institut a microfilmé le meilleur exemplaire qu'il lui a été possible de se procurer. Les détails de cet exemplaire qul sont peut-être uniques du point de vue bibliographlque, qui peuvent modifier une image reproduite, ou qui peuvent exiger une modification dans la méthode normale de filmage sont Indiqués cl-dessous.

\section{Coloured pages / Pages de couleur}

Pages damaged / Pages endommagées

Pages restored and/or lamiriated /

Pages restaurées et/ou pelliculées

Pages discoloured, stained or foxed /

Pages décolorées, tachetées ou piquées

Pages detached / Pages détachées

\section{Showthrough / Transparence}

Quality of print varies /

Qualité inégale de l'impression

Includes supplementary material /

Comprend du matériel supplémentaire

Pages wholly or partially obscured by errata slips, tissues, etc., have been refilmed to ensure the best possible image / Les pages totalement ou partiellement obscurcies par un feuillet d'errata, une pelure, etc., ont été filmées à nouveau de façon à obtenir la meilleure image possible.

Opposing pages with varying colouration or discolourations are filmed twice to ensure the best possible image / Les pages s'opposant ayant des colorations variables ou des décolorations sont filmées deux fois afin d'obtenir la meilleure image possible.

Thls Item is filmed at the reductlon ratio checked below I

Ce document est fllmb au taux de rétuction Indique cl-dessous.

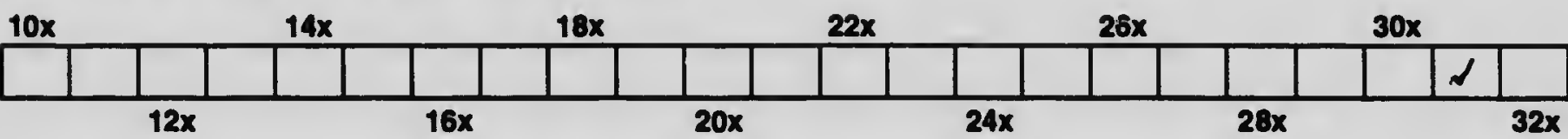


The copy filmed here hes been reproduced thenks to the generosity of:

National Library of Canada

The imegee eppearing hore are the best quallty possible considering the condition and logibillty of the orlginal copy and in keoplng with the fllming contract specifleations.

Original coples in printed papar covere ore fllmed beginning with the front cover end ending on the last page with o printed or lllustroted Impression, of the beck cover when opproprioto. All other original copies ere filmed beginning on the first poge with - printed or llluatroted Impreesion. ond ending on the lest pege with o printed or lllustroted impression.

The lest recordod frome on eech microfiche shall contain the symbol $\rightarrow$ Imeening "CON. TINUED"I, or the symbol $\nabla$ (mooning "END"). whichever opplies.

Mops. plates, cherts. otc., may be filmod ot different reduction rotios. Those too lorge to be entirely included in one exposure ore fllmed beginning in the upper lote hand corner, left to right and sop to bortom. es meny fremes es required. The following diegrems lllustrate the mothod:
L'exemplaire filmd fut reproduit grdee of to goncrosits da:

\section{Bibliotheque nationalo du Canada}

Les images sulventes ont bet raproduites avec la plus grend soln. compte tonu do le condition ot de la norrote do l'oxomplaire tllmb. ot on conformizb ovec loe conditions du controt de flimoge.

Les exempleires orlolneux dont is couveriurs en popler eat imprimbe sont fllmbs on commencent par is promier piat at en torminont soit per lo dernidre pege qul comporte une empreinte d'impression ou dillustrotion. soit por le second piot, selon is ces. Tous lee sutres oxamploires orlginoux sont fllmise on commoncent por lo promidre pege qul comporte une empreinte d'Impression ou d'iliustration ot on sarminont por lo dernibre page qui comporte une talle empreinte.

Un des symboles suivents apparoitre sup lo dernibre imege de chaque mieroficha. solon le cos: io avmboio $\longrightarrow$ slgnifio "A SUIVAE". Io ermboio $\nabla$ slonifio "FIN".

Los cortos. planches. Ebblooux, otc.. pouvent òtre filmba d des taux do rlduction diffórents. Lorsque lo document est trop grend pour utre reproduit on un soul ellehb. II eat fllmb portir do l'engle supdrlour goucho. do goucho d droire. ot de haut on bas. en pronant lo nombre d'imeges nteeseaire. Les diegremmes suivents illuotrent is mothode.
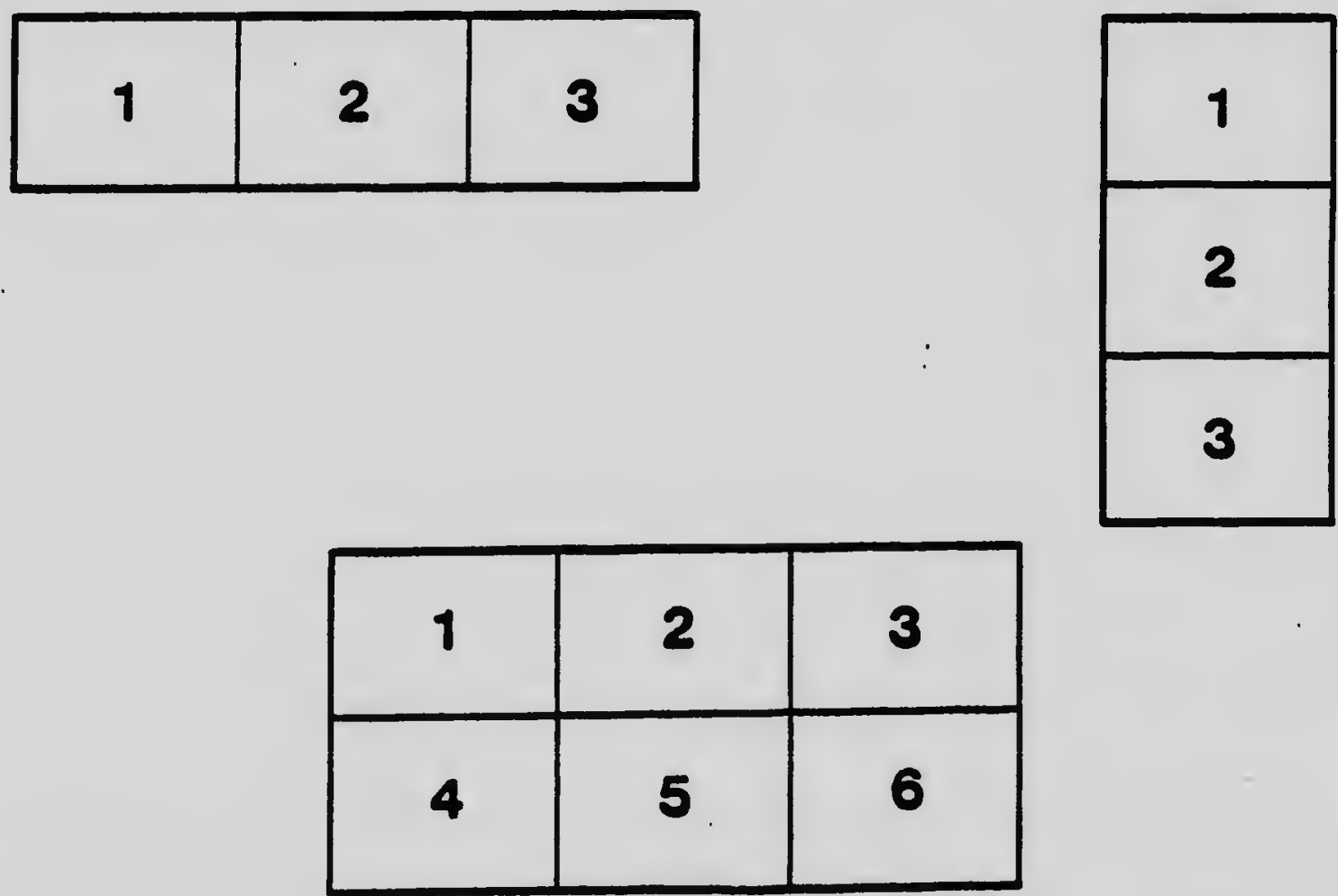


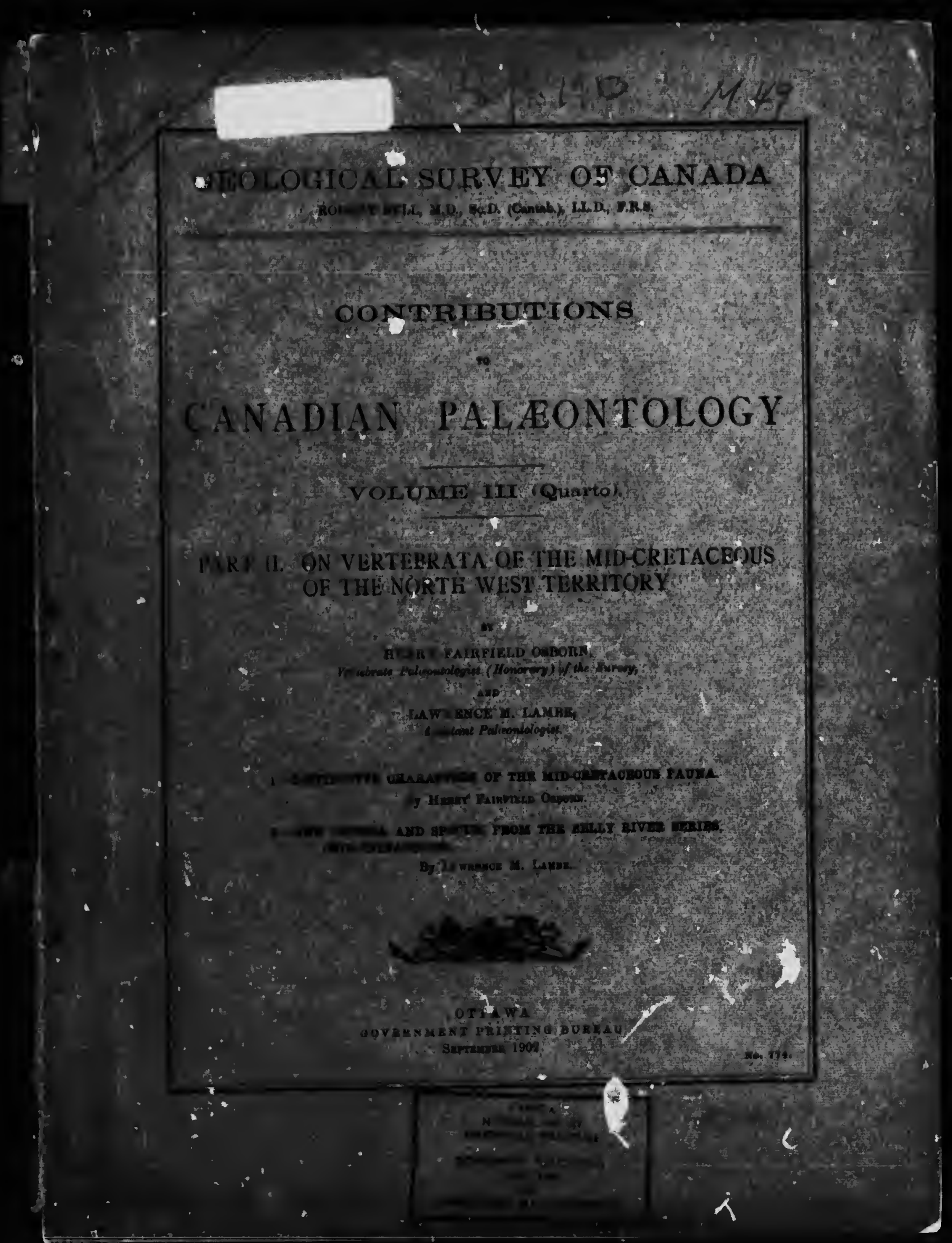




\section{GEOLOGICAL, SURVEY UF CANADA

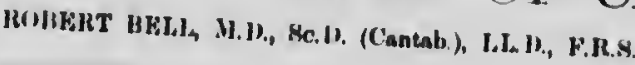

\section{CONTIRIUTIONS}

ro

\section{CANADIAN

VOLUME III (Qunrto). OF 'TILE NORTH WEST' TERKITORY

nY

IIENRY FAIRFIELD OSBORN,

Vertolvate I'alirontologist (Ilonorary) of the Surrey, AND

IAWHENCE M. IAMHF, $U /$ Annistane Palironeologint.

1.-DISTINCTIVE CHARACTERS OF THE MID-CRETACBOUS FAUNA. By Henky FAlkmeld OghoRs. EW GENERA AND SPECIES FROM THS BELLY RIVER BERIES
(MID-CRETACEOOS).

BY JaWhENCE M. LAMHE.

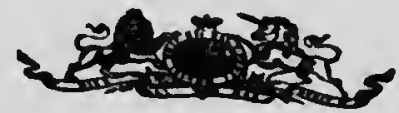

OTTAWA

GOVELNMENT PRIXTING HUKEAU

SEPTEMeER 1902 


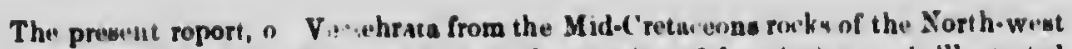
Trrritory of Cenada, forms the mecond part of " series of descriptive and illustrated quarto inemoirs" begun in 18 !1.

The firat part, hy the late Irofenen F. I). Cope, is ou "The species from thes Olignene or Lower Mio'ell. beds of the Cypresu Hillo".

The pablication of a contemplatid second part on the Vertebruts of the Iaramie formation of the North-west Territory, also by nrofessor Cope, was prevented by his death in 1897.

The Snrvoy is decoply indehted to Profossor Henry Fuirfield Oaborn, Curator of the Department if Vertebrate Paluontology of the Ameriran Museum of Natnral History, New York, for having kindly consented, at the request of the late Dr. George M. Jaweon, to snpervise the working np of the vertehrate fossils in its possesuion. This asistance has been given quito gratnitously by l'rofeser Osboru, who, besides having twice visited Uttaka in this counetion, has also dovoted some tims to the consideration of the more general geological and paleontological relations of some of these fossils, as set forh in his introdnction.

In the preparation of tho prosent report Mr. Lambe has had the advico and supervision of Protuesor Ouborn.

LOBELT BELL.

\section{Geological Surviy Departuent,}

OTrawa, 30th July, $190 \mathrm{~g}$. 



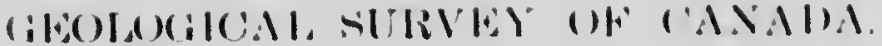

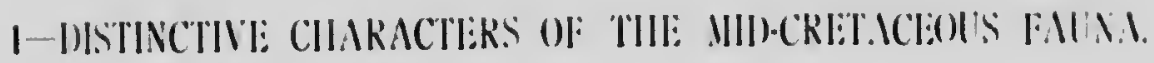

BY

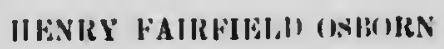




\title{
GEOLOGICAL, SURVEY OF (UNADA
}

\section{1. -JISTINCTIVE CHARACTERS OF THL MII.('RITACEOÜS LAINA.}

\author{
BY HeNhY FatRftet, (MamiRN
}

The detromination by the Canadiun Survey of a Mid-Cretaceus and fresh-water fauns, including tishes, batrachians, reptiles und mimmals, is a forwarl step of great importance in vortehrate palirontology.

The Survey had estahlished leyond question, greologically, that the linlly Rirer sorios is Mid-Cretareons, that it underlies the Montana or Ft. l'ierre-lox llills group, und overlies the Ft. Benton and Dukotil groups; * and at the ontset of the pulanontologinal in restigations for this report, the question arose, what staces of vertelorite "volution are repremented by the Bully River fauna?

It som appoured to the writer in the study of the fine collection ande by Mr. laumbe that the Belly liver vertebrites of the North-west Territory were of devilielly different and apparently of older type than those from the Laramie beds of converse so. Wyoming, deseribed by Marsh, and were rather to be compared witl those deseribed lyy lsidy, Cope and Marsh, from Montana, chiefly from tlee. Inditlı River leds, a region hy no means distant geographically.

Thus the correlation between the Belly River and Judith River sories, proposed by the late Direntor, Dr. (7. M. Dawson, in 1K75, at first erlanie appeared to be coufirmed faunistically. But this correlation is not supportod ly the genlogisal reords, which all place the Judith River beds proper above the Fox IIills and Fort Pierre.

To present the "videner for and against the Mid-Critareous age of some of the Montana fossils already known, to show the newd of cleser examination of the geology and 'loser comparison of types, and to outline the greneral charueteristies of this fuuna, are the 'hinf olje'ts of this introduction. Non seologin sine palirontoloria; in other worls, no fannal work wiil endure which is not hised on stratigraphical work.

\section{1. (íolochicat, Relations.}

Among geologists of the United states there has nerer been any question as to the Laramie or Uppor (Yretaceous age of the typiesl Judith River heds. In 147\%. Cope

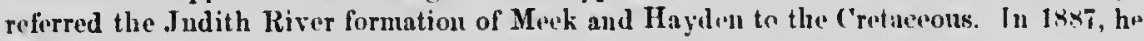

\footnotetext{
- The history of this work is presented ly Mr. Lanke in the sorond pat of this monuir.
} 
questioned Dr. Hawson's assignment of greater age: to the Belly River series, holding that the vertebrates Wert: similar to those of tho Laramie. C. A. White* takes a similar view: "What given this (Belly IRiver) formation especial interest is the intimate relation fits funna and flora to thos of the Iaramie, although these two non-marine formations ure, in the district within whil.h both are known to oceur, separated hy a great thickness of strata which are unmistakahly of marine origin." Whitman Cross ** places the udith liver heds even higher: "Withont reviewing in detail the literature of these it is desired to point ont the fart that the Iudith River strata may perhnps represent the Arahapahov or some other post-Laramit formation and not the true Laramie of Colorado and Wyoming."

Other observations, however, point to the presence of older fresh-water heds in Montina, which may have leen more or less confused by colleetors with the Jndith River heds. White, remarks, (op. cit. p. 17t): "Certain ohserved conditions of strata exposed along the Nissonri river in northern Montana apparently indicate its li.e. Belly River formation] presenee there. It also seems not improhuhle that some of the strata in the npper part of the ralley of the Musselshell river, in Montana, which hare been referred to the isaramie, really belonged to the Belly River formation. If atrata of this formation renlly exist there they prohnbly were oriurinally continuous with those of the Belly River ralley." More recently liurl Douglas *** has obsirved Mid-Cretareous dinnsaurs helow the. Ft. Pierre heds, in Swert-grass county, Missouri.

In the records as they stand, therefore, there is evidence, first, of fresh-water dinosinulowing lods in Montana older than tho Laramio; and this suggests the possilsility, not to say probubility, of confusion in the collections; that is sume of the vertchrates alroaly distrihed from Montana may be of Belly River age.

Neither in the writings of Cope nor Marsh is the fout reeognized that some of the Wontaus rertebrates are of different and perhaps more nueient character. Even in their latest contributions **** to the subje.t, Montina and Wyoming verlubrates are disenssed as of the same age, and as if the question were one of priority of nomenclatnre rather than the more important one of priority of strueture and time. Marsh (op. (it., p. 145) places the "Ceratops Beds of Laramie Series" abore the For Hills group, as the snmmit of the ('retanmus. 11. de.fines (op. cit., p. 207) these beds as follows :-

(p. 207). "The definite horizon in which these strange reptiles occur has been called by the writers the Ceratops beds, frou the type genus Ceratops, and its position is shown in the section on page 145.... This geolugical horizon is a listinct one in the upper Cretaceous, and is indieated for more than 800 milcs along the eastern fiank of the lincky Mountains. It is marked at nearly every outcrop hy remains of these reptiles, ant lience the strata containing them have been called the Ceratops berls. They are fresh-water or lurackish deposits which form a part of the so-called Istramie, but wre below the uplermost beds referred to that group. In some places, at least, they rest upon marine beds, which contain invertelsrate fossils tharacteristic of the Fox Hills deposits The most inportant lowalities in the Ccratops beds are in Wyoming, especially in Cunverse County.... The fossils associated with the Ceratopaide are mainly linosanrs, representing one or two order and several families. Plesiosaurs, crocodiles, and turtles, of Cretaceous types, und many smaller reptiks, have loft their remains in the

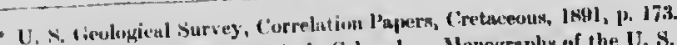

, Cientegieal survey, Vol. XXVI1, p. 239.

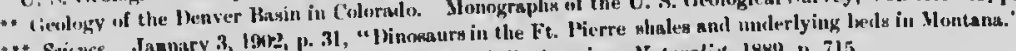

, Auprican Naturalist, 18k9, p. 715 .

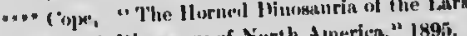

Harkh, " Hinusanes of North Ainerica," 1895 
that

inilar ation ations kness 8 the these repremie of

Monliver xposed River in the ferred mation y River below

nosturity, not alroidy ce of the in their dist'uts. re rather o. 14i) stuminit ed by the on on page d for nore ry outcrop atops beds. below the ds, which lities in the d with the Plesionaurs, ains in the

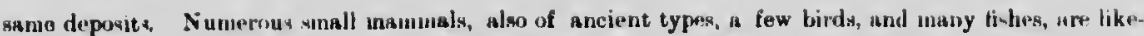
wise entombed in this formation. Invertoluste fosvils and plats are not unemmon in tlie sane lorizon

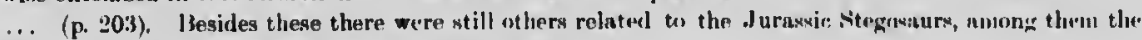
Fodozanridir, "1uadruperlal forms heavy dernıal arusor."

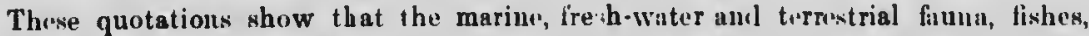
plesiosaurs, as well as stegosaurs wer. all included by Marsh in the Larumin finum of the

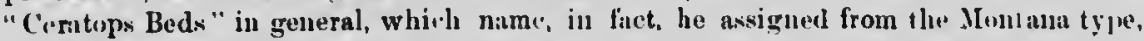

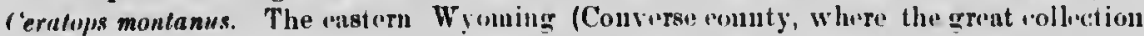
"f Tricerafops skulls was made by IIateher), the wostorn Wymuine (Bitter C'rek) Laranio

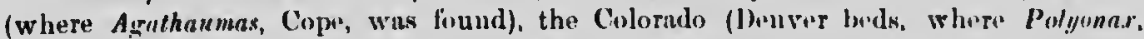
Cope and Cerntops alticorwis wer. fomll), and the Montana (Jullith livirs and supposed Fort Union), arv all treated by this author as of th" sam" age, namely, Cpper ('retaveus.

The confusion has binu rendured rrwater in the early references of some of the Ilontana fossils to the For Union beds. A year after Copr's orivinul description of his "Fort Union" collurtion he transferred them to the Julith River, in his piluer on the "Geology of the Judith River beds." The Ft. Union beds hare berll considerwl lat. ('retareous or on the border land betwen Cretaceous and Tertiary. In 18it-i, (i. M. Mawson published ceveral papers expressing tle opinion that they are Eot'ellu. L. F. Ward refirred the Fit. Union beds to the Upper Laramie, from its flora; on the sum, gronud Newberry placel it above the Laramie in the Tertiary. Quite recenlly Mr. Earl Donglas has nade the very fortunate disiovery in these beds of basil Linen' mammals of Puerco (Thanctien Montien) are. The reference of Montana dimosants to Fort Lnion beds is, therefore, an (rror.

It remains to 'se detrrmined, therefore, whether all th' fossils rin'orded from Montana are artually from Judith River beds, or whether a portion at lenst of the beds deseribed and collected in as "Judith River" are not older thun the Laramie.

\section{Pinulisional Correlatiox}

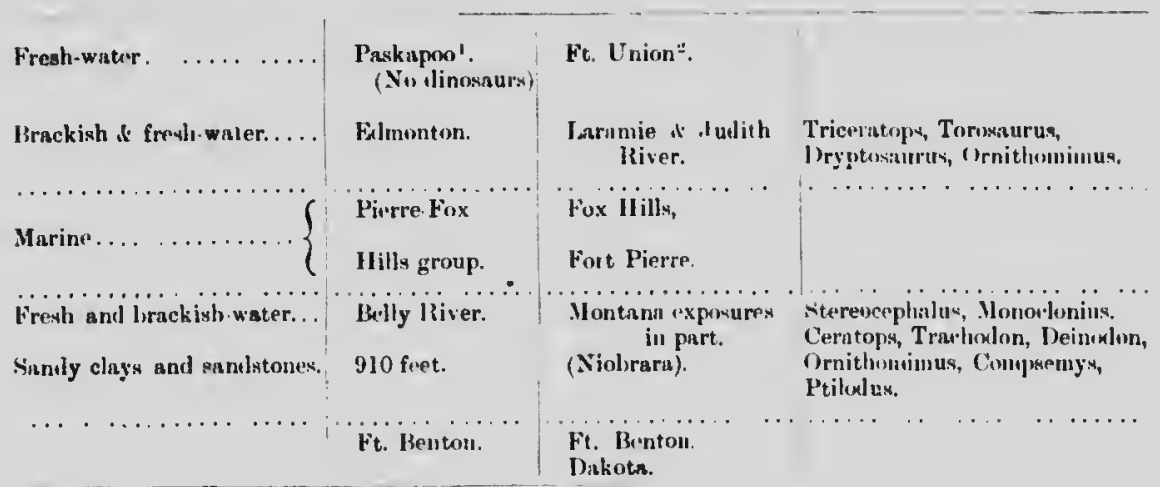

'. Regarded ly Tyrrell a* the Ineginning of the Tertiary.

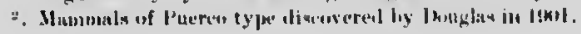




\section{Famnat. Characters.}

The Bully River or Mid-('rotacenus fauna is distingnished from that $n$ f tiw Upper Jurani. (Como lieds, Purberekien) by the entire nbsence of Samropoda and hy the presente of Ceratopsia in great variety. It is affiliated with that of the Jnrassic, and so fur as we kuow keparatel from that of the Laramis by the presence of highly specialized Ntegosauria or plated dimosanrs, by numerous turtles of the Jurassic family Pleurosternide. and ly utunerous large l'lesiosaurs.

Nummarixing the table and with allowance for the prcvisional character of many of the doternninations and of our incomplete faunal list, it appears that the (i) Belly River. (ii) Julith River and other beds erroneonsly referrel to "liort Union" of Montanu, (iii) Larmmin of II yomine and ('clorado are reluted as follows:

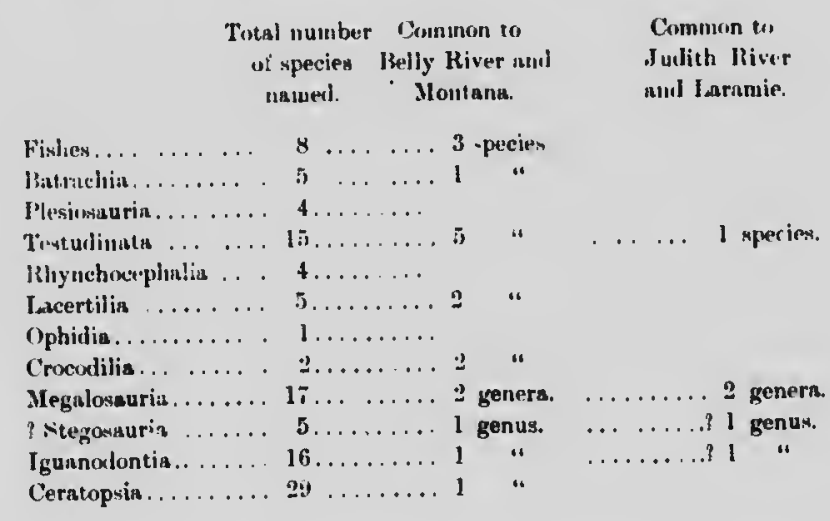

It should be plearly stated that our knowledge is so inaccurate as to rob this comparixon of inuch pirmanent ralue.

There is thus riry little in common between the Belly River fauna and the Laramie linuna of Wyoming and Coloralo so far as derseribed, exiept the dinosaur Ornithomimus and the rory persistent helonian Buëan. Most of the dinosaurs will probably be found to he separated generically.

On the other hand, so far as known, the Montana fauna has much in conmon with th" lielly River, esperialy among the Testudinata, Iguanodọntia and Ceratopsia.

In the following tablis, which has been compiled with the aid of Mr. Lambe and Dr. (1. P. Hay, the greological and geographical references are those given by the authors. Luidv's carly refirences to the "lignite of Nebraska" are to territory now included in Dakota and Montaua. In the second column are animals specified as in "Julith River beds"; in the thirl thos" entered us "Fort Union" or Laramie of Montana, largely Judith River no

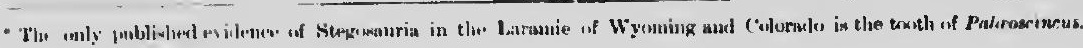


doubt. In tice fonrth column, the Morean River region of Dakotu. In the filth, Wyoming, Courerse co. and Bitter Creek. In the sirth, the Colorado Laramie. In the serenth, the Edmonton beds of Alberta, which correspond with the true Linamie.

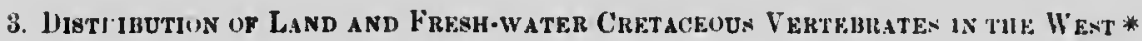
Omilling Laramie Mamruals

8 coinpa-

Laramic

thomimus be found

non with

ambe and authors. in Dakota beds"; in River no

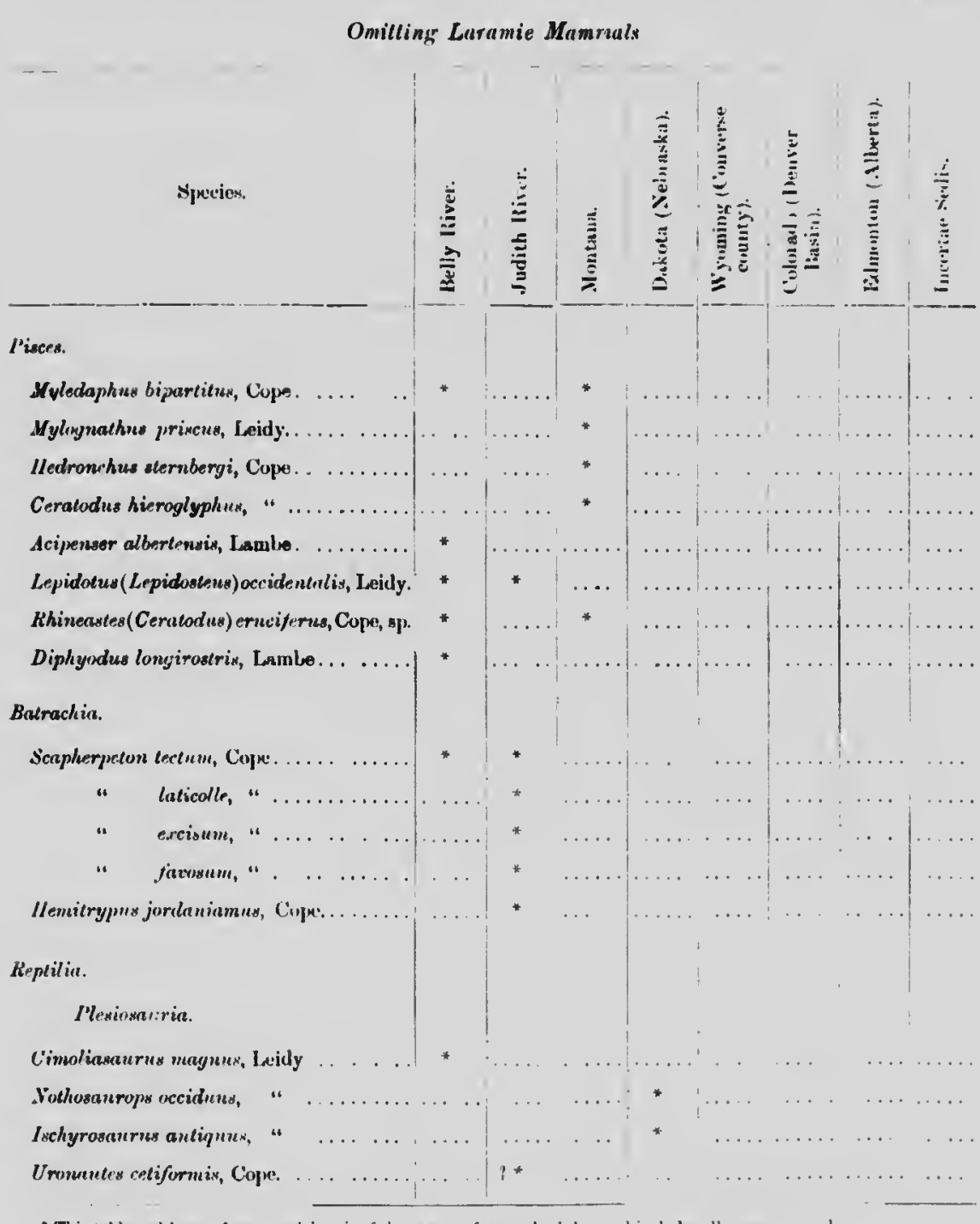

sjuvies. 


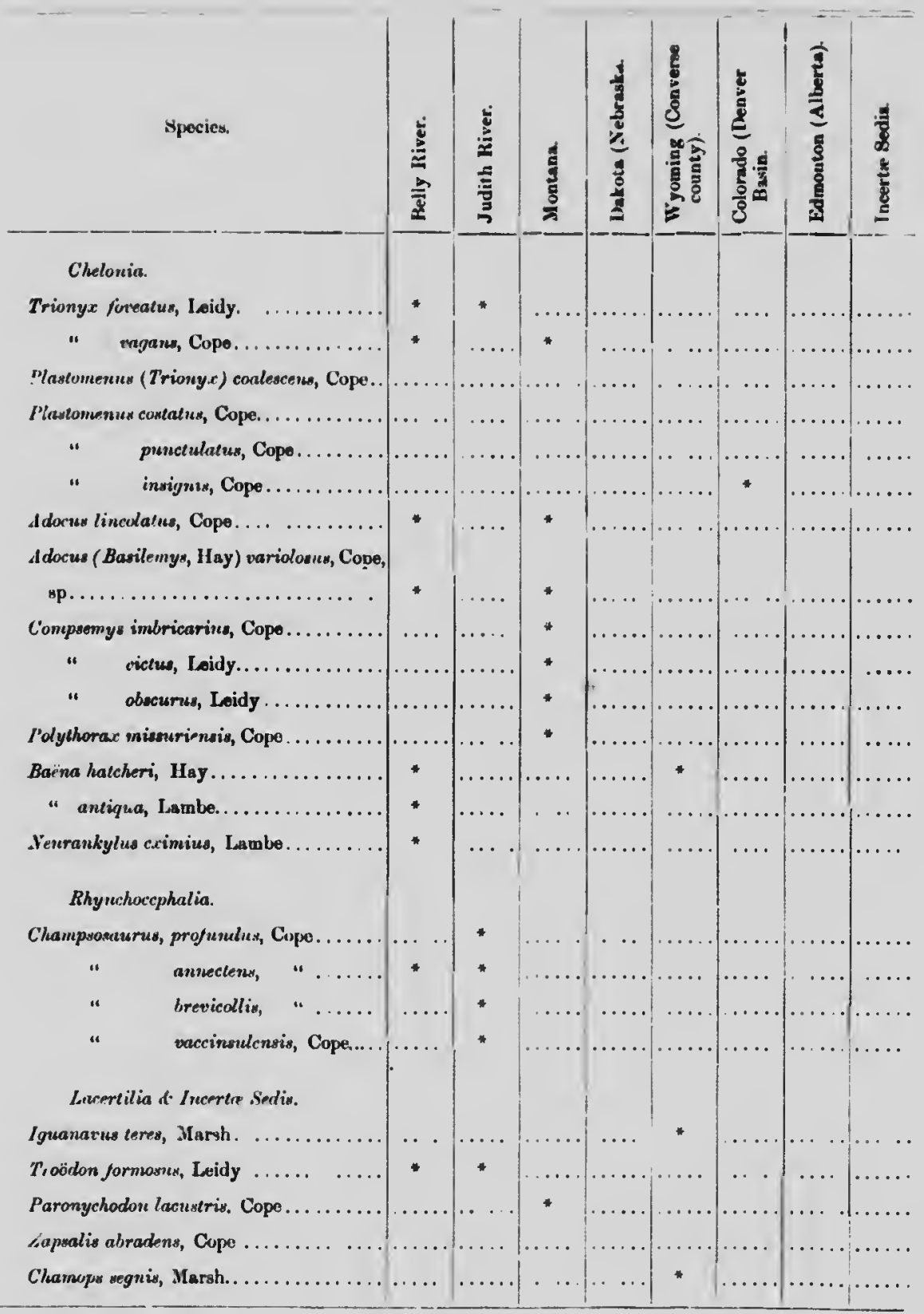




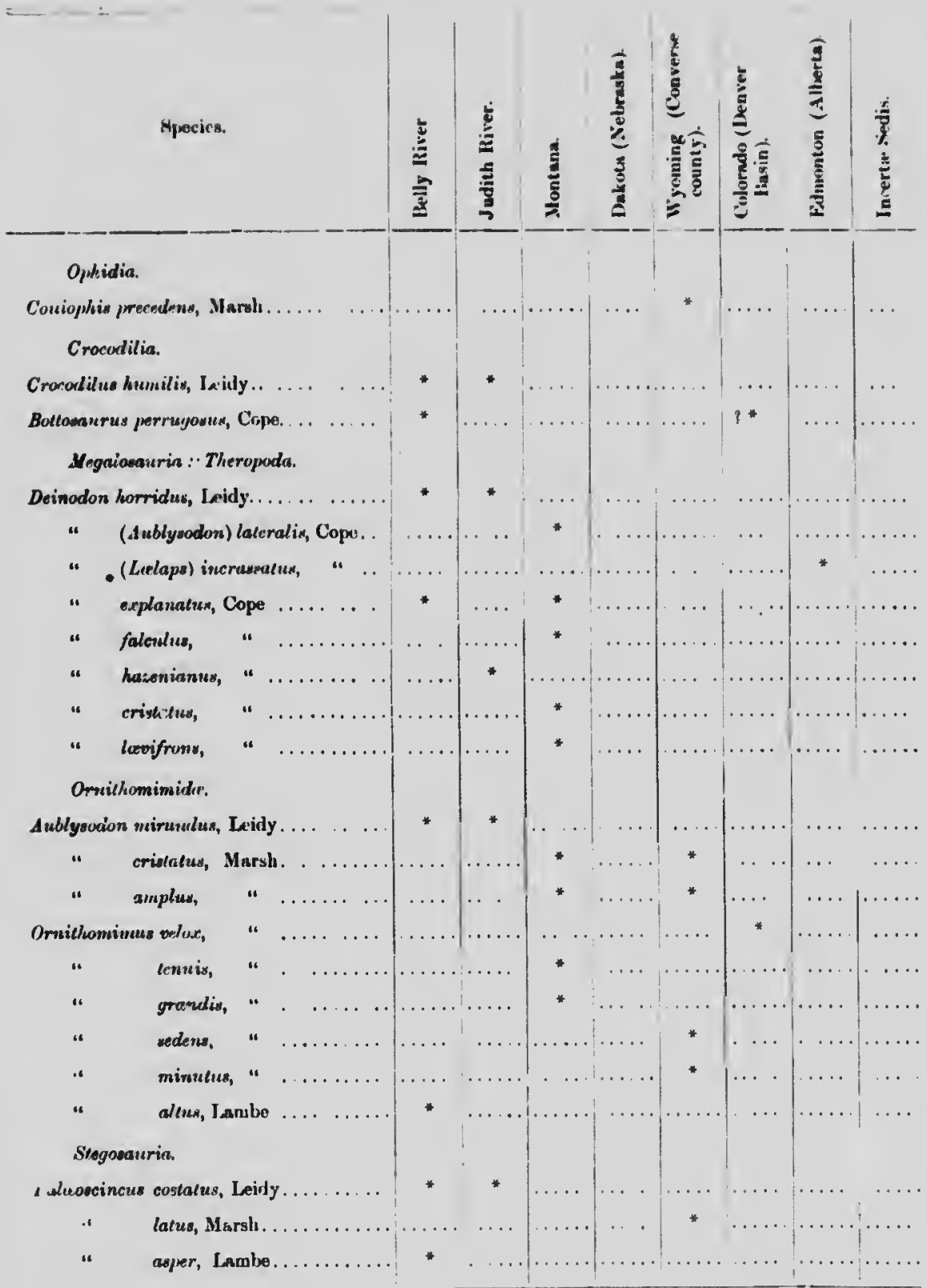




\begin{tabular}{|c|c|c|c|c|c|c|c|c|}
\hline \multicolumn{2}{|c|}{ Nipriea. } & 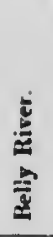 & 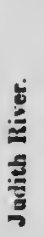 & $\frac{d}{d}$ & 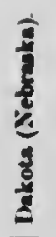 & 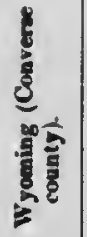 & 递 & $\frac{1}{\frac{1}{3}}$ \\
\hline \multicolumn{9}{|c|}{ Steyomanria-Con. } \\
\hline \multicolumn{9}{|c|}{ Sudomuru errtilin, Marsls. } \\
\hline \multicolumn{9}{|c|}{ Sterecocephalue tutun, Iamive } \\
\hline \multicolumn{9}{|l|}{ Cerutopsia. } \\
\hline \multicolumn{9}{|c|}{ Agathaumaw sylrestre, Cope..... .... } \\
\hline \multicolumn{9}{|c|}{ I'olponax mortharius, “ ........... } \\
\hline \multicolumn{9}{|l|}{ Dyngninus encaustius } \\
\hline \multicolumn{9}{|c|}{ " haydsinianus ". } \\
\hline \multicolumn{9}{|c|}{ " bicarivalius, " } \\
\hline \multicolumn{9}{|c|}{ “ peiganus, } \\
\hline \multicolumn{9}{|c|}{ Monoclonines crassus, } \\
\hline \multicolumn{9}{|c|}{.. recurvicornis, “" } \\
\hline \multicolumn{9}{|c|}{ " suhenoceris", " } \\
\hline \multicolumn{9}{|l|}{ " fissures, } \\
\hline \multicolumn{9}{|c|}{ “ dacsoni, Iambo } \\
\hline \multicolumn{9}{|c|}{. canadennis “. } \\
\hline " belli, & “ & " & & & & & & \\
\hline & & \\
\hline " allicornis & “. . & & & & & & * & \\
\hline \multicolumn{9}{|c|}{ 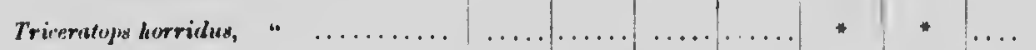 } \\
\hline \multicolumn{9}{|c|}{ " serral"s, .. } \\
\hline \multicolumn{9}{|l|}{ " prorsus, } \\
\hline \multicolumn{9}{|c|}{ " sudcalies, .. } \\
\hline " elatus, & “ & \\
\hline \multicolumn{9}{|c|}{ " calicornis, Marsh } \\
\hline \multicolumn{9}{|l|}{ " guleus, } \\
\hline " oltusus, & $"$ & $\cdots$ & & $\ldots$ & & * & & \\
\hline Sterrlualoplute flaberll & & & & & & * & & \\
\hline Turosauries laties, & " & & & & & * & & \\
\hline
\end{tabular}




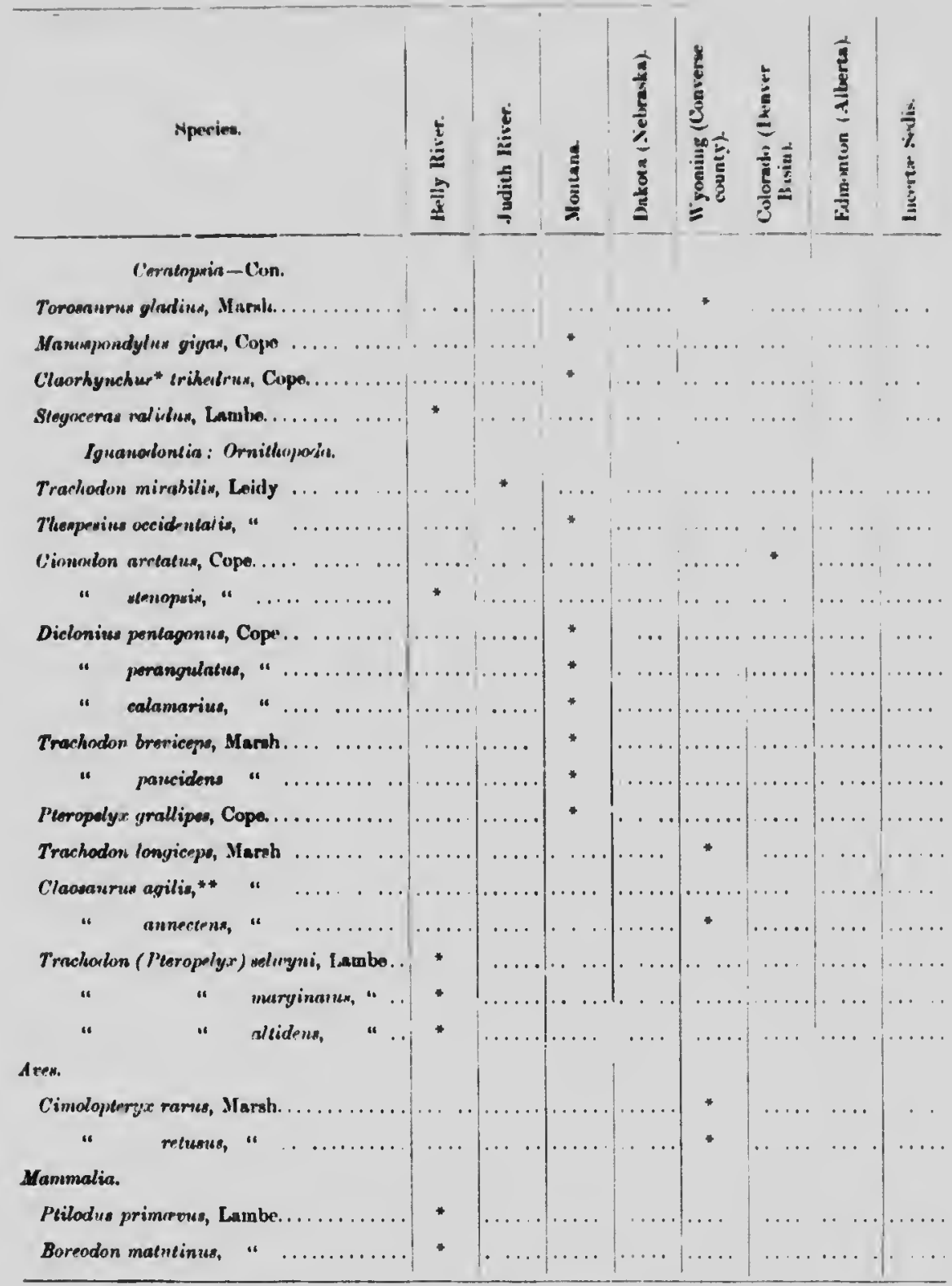

"This nay be an igruanualont.

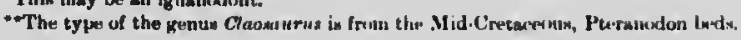




\section{risIIRN.}

Th. fishor includio truly unarin. an woll as loakixh und frowh-wator typew, and a all of Montana and Allwria rofiromiles.

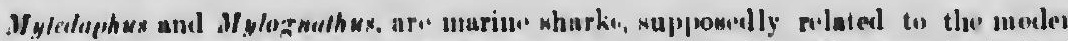

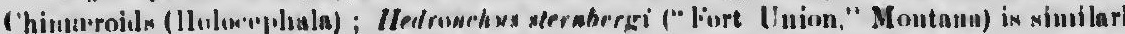

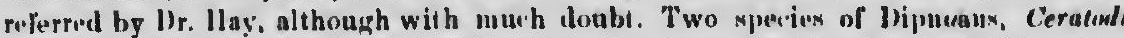
hirrogluphus and $C$. (Rhinenstex) eruciferns uro ulso from th. Montanu and llelly live

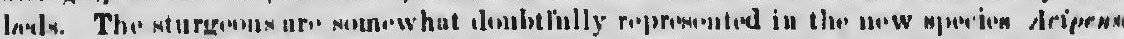

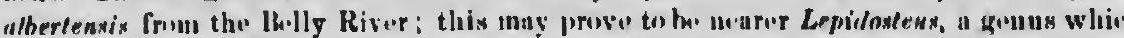

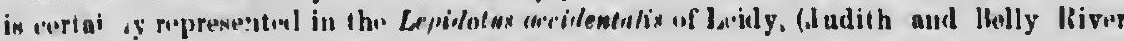

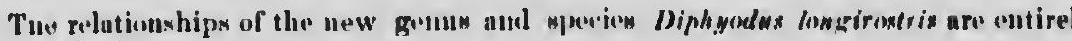
problinatioul.

\section{HATHACIIA}

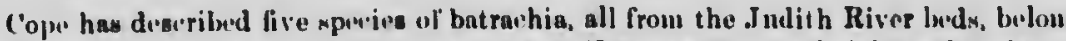
ing to the two Urodiolo grueru sirnpherpelon and Hemitrypus, ol doulstul family relatio

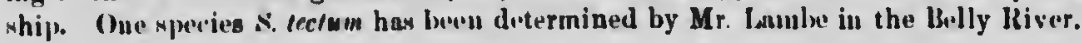

No Intra.hiats are reourdal from the Wyoning laramie.

\section{REPTILIA.}

Plibsjosatras. Numerous rertibrar of a largo plesiosane from the Belly liver a provisionally roferred to the New Jersey species Cimoliasaurus magnms, Laidy. Fro Morman river, Nouth Dukotu, Luidy has dencribed twu Plesiosaurs, Nuthosnurops occidw and Ischyrosaurus "ntipuus; whother these bed a we of llelly River uge or more recint not known. Uronawtrx celiformix, Cope is unother plesiosaur from the Judith River.

Cumbonis. Turtlen of the snb-order Trionychin are abundant. Ouc species, Trion:

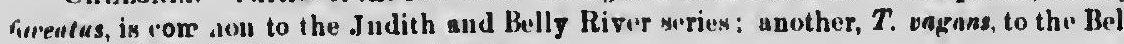
liiv'r und suy, oned" "lit. Union" beds.

Threp other spmies, Plusfumenus confatus, $P$. ronlesrens and $P$. pun'tulatus have be named h, Copc. the first two from the Laramic of the "bad lands" south of Wo Mountain, Assiniboia, th" third irom thr supposed "Ft. Union" (Judith lRiver) of Mo1 ana. Dr. llay obserres .hat it is uot muliknly that $\boldsymbol{P}$. rvalescens is a synouym of Trinn ruguns; P. costatus anci $P$. punctulutus ure nlso nore likely to loelong to Trionyx. Plt tomenus is distinctivoly an locene genus.

The order CRy ptodirs is inprosenled ly lare swanp tart lis rolated to the $D$-rmatem diller, but belouring to the family Alocille; these are Adocus lineolalus, Cope, A. (Basilem or "royal turtle". Huy) mriolosw, nnd A. (Basilemys) imbricarius; the royal turtle is ro large and waboritely silptured. It is importast to note that the two species lit nanid are found both in the lielly River and in Montuna (?" Ft. Union "), teatifying the Mid-('retarens age of the latter. The prescnece of numerous specien of the Juras:

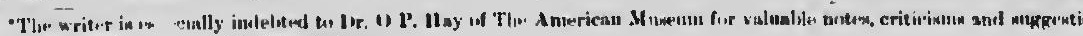

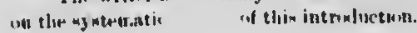


*w, and aro

the inoulers is minilarly - Cerulimlus hally River Ariprnuer 'uum whioh lly livir). arc "utirely

dw, bilonge ly relationliver.

- liver are idy. From ps occiduns ore recint is River.

ien, Trinnyx to the Belly

s have becll th of Wood r) of Montof Trimnyx inyx. P/as-

D-rmulemy1. Basilemys urtle is very previes lirst testifying to the Jurassic

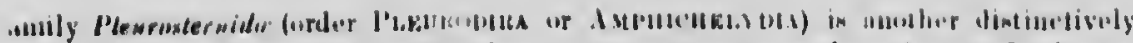

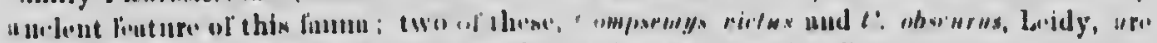

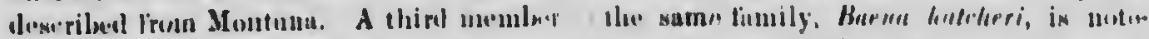

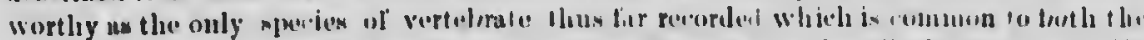

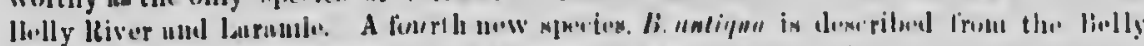

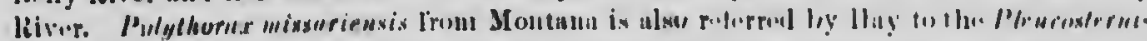

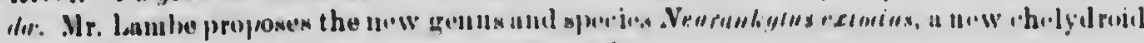
turtlo, diutinguimlud liy u supermunorary analal.

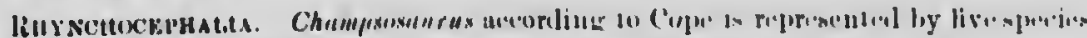

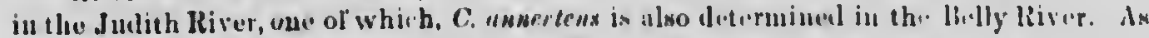

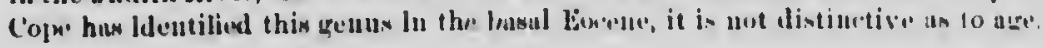

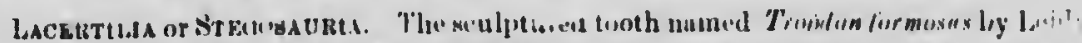

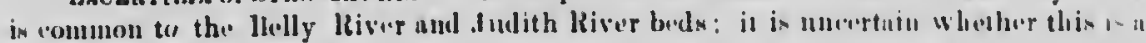

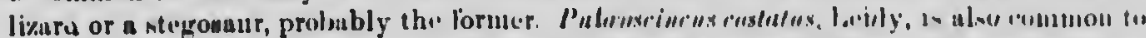

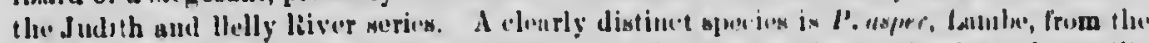

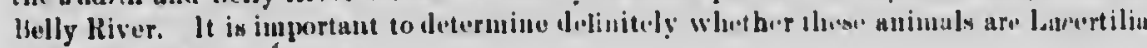
or Stegosauria.

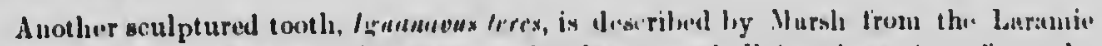

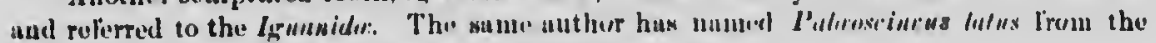

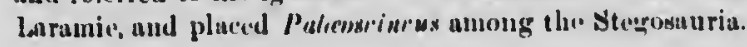

Crocontus. The sperien Crmoulelus leumiles of the Indith liver is provinionally

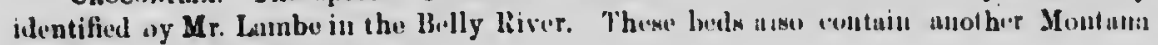
"ronerlile, Butensunrus perrugusus, Copn'.

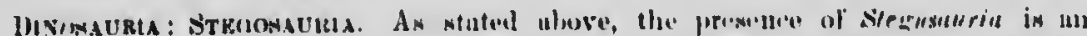

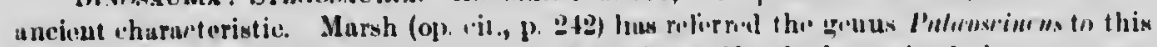

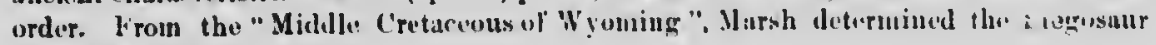
Ninlosnurus (op. 1.it., J'. 2agi).

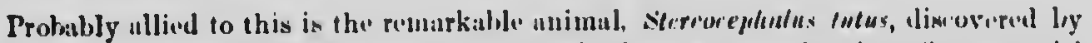

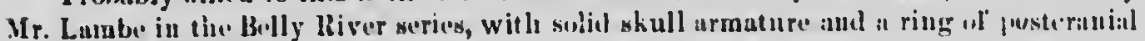
pointed ossicless.

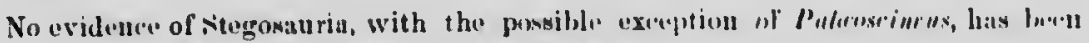
recorled from the Wyoming Laramic, l'puner Cretaceous.

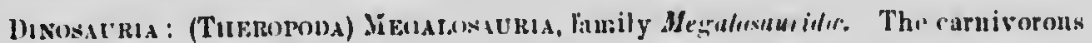

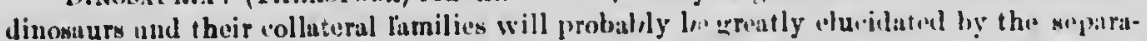

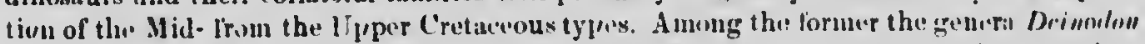

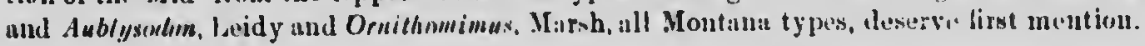

After Marsh had substituted the name Dryptosunrus lor the pronecupied name La'laps (whioh Cope hal employid lor an Upper C'retaceous of New Jursey ('arnivore) it was generally supposed that all large Crotaceous carnivores should ln rolerred to II arsh's gents. If, howeser, the largo. I ulith literer type, which has its commterpart in the linl!y River, is Mid-l'rofuccous, it is in all probability aruerically tistiunt and Leidy's namu 
Is

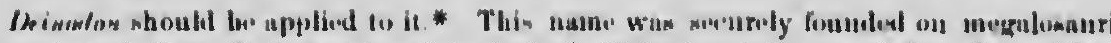

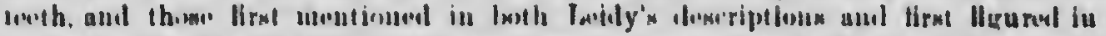

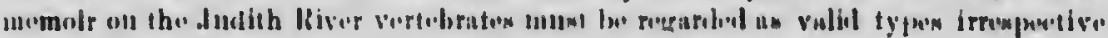

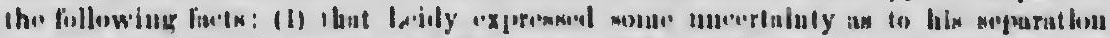

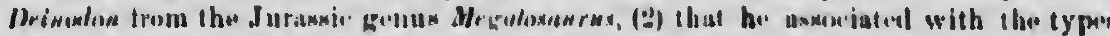

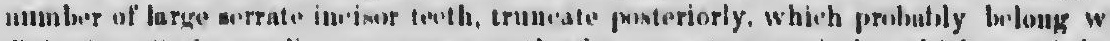

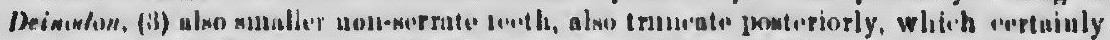

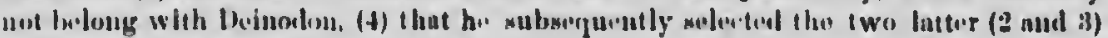
the typen ol Awhyoulin.

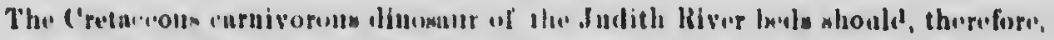

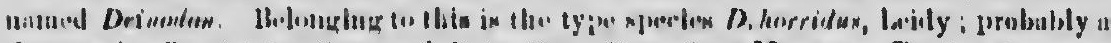

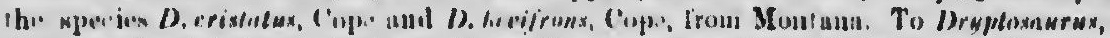

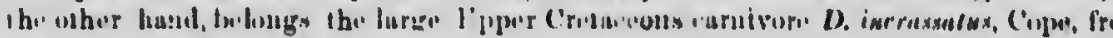
th. listmomtoll meriug of Allortit.

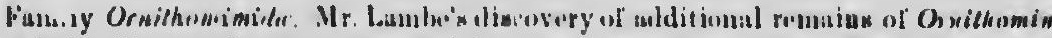

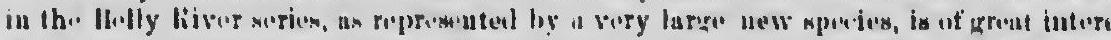

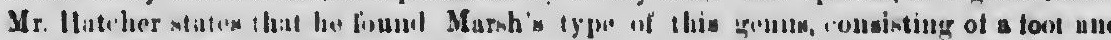

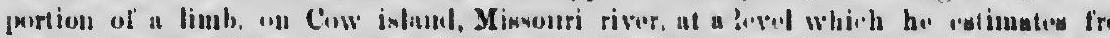

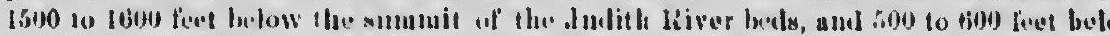

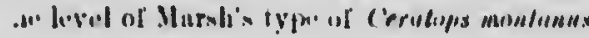

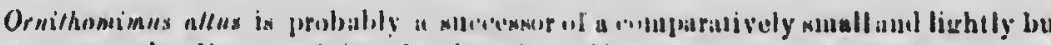
dinosanr ricrully disiovered by the Anerious Museun partios in the Como bids

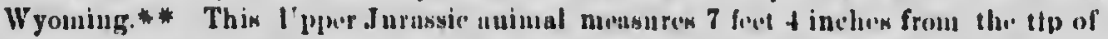
promaxillarios to the tip of its tail. Listimated by the compurative size of its me" apon? the Mid-C'retucerous (). allus was:

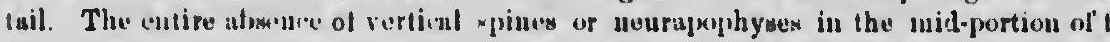

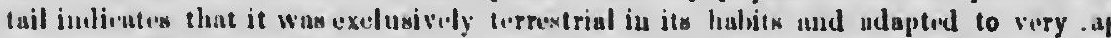

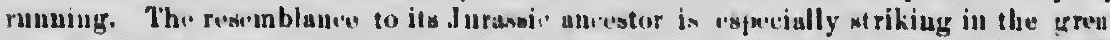

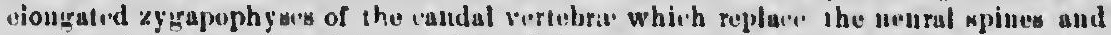
111. lateral comprension of the lorminal phalungen of'the in:unus. Ornithomimus is in

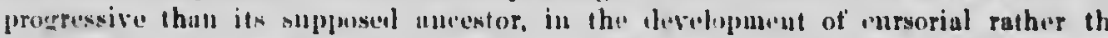

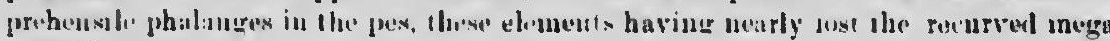
situroid strueture.

The tenth of thin genus :tre nut klluwn: but comparison with its Inrussic protoly

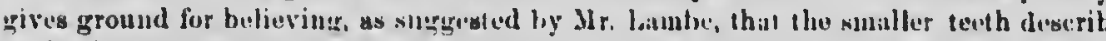

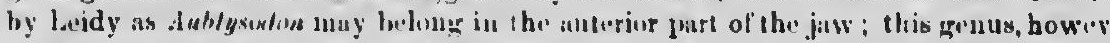

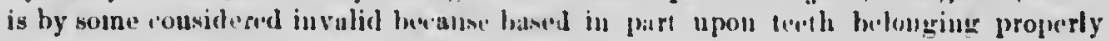
Deinodon.

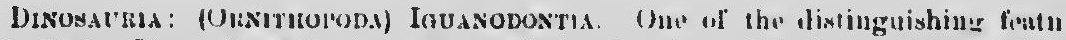
of the llelly River launa is the griat number and variety of th. Inumbonom. Or

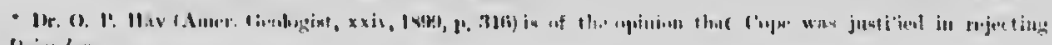

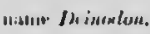

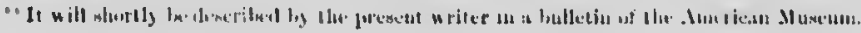




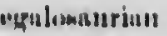
yureyl in his "uxpret/ve of "puratlom of tlie typom inlong witis c'rtuinly do (2 nud 3) a.

huraforc, Ix" orobully $n$ lxu ulowanrwe, (t)I C'incu, frum

\section{J nithomilmas} rout interwat. a loot and a iulati's froun 0) linet below

lightly built omo birls of h. tlp of it. met apon? tals and slindirr ortion of tli" o viry . splal tlio xreatly iues and in mus is mor" rather than rowl inegalo.

in: prototyp" th ilesiribur us, how'ever, propuerly to

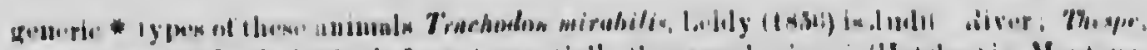

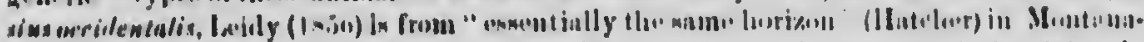

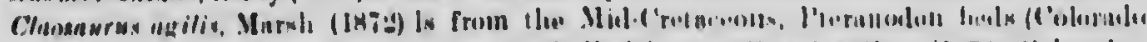

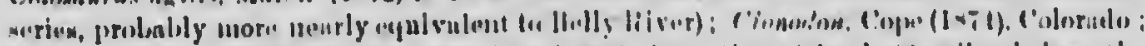

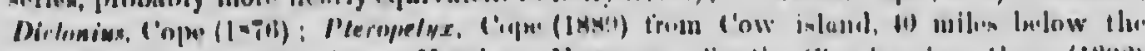

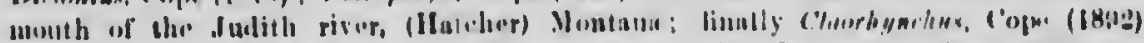

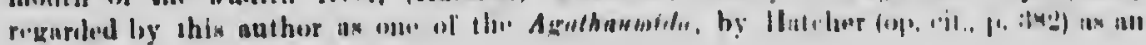
igututuodnit.

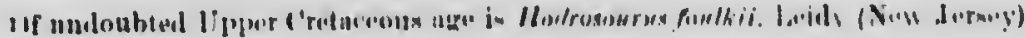

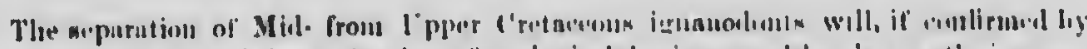

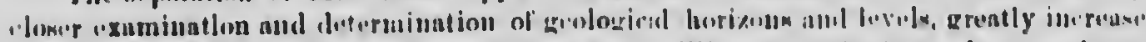

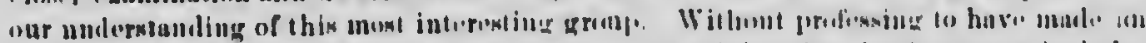

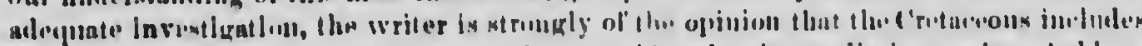

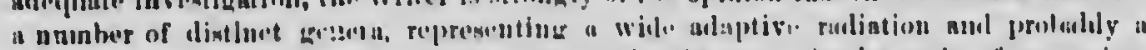

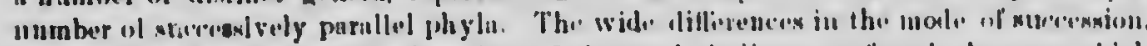

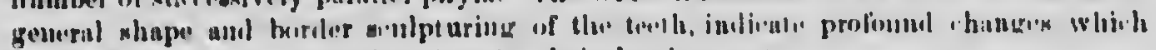
required an enormons perind of time liar their derelopmonent.

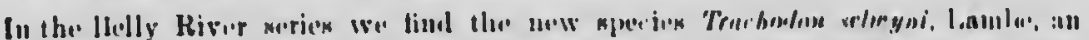

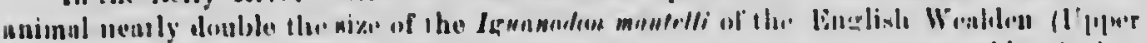

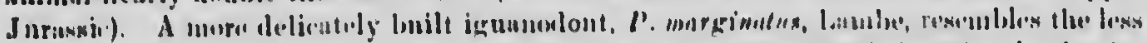

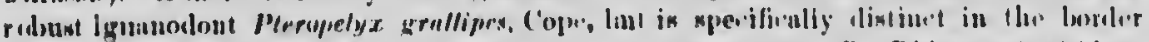

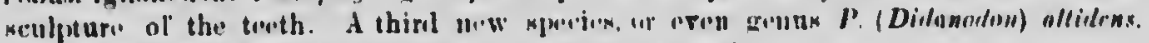
Lamler, distinguinhed lig axieptionally high unrow tontli.

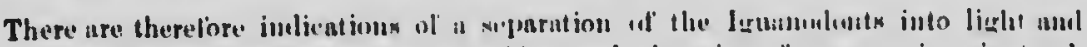

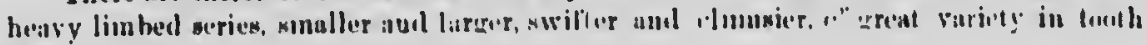
wtruiture.

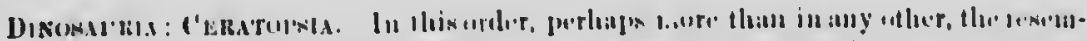

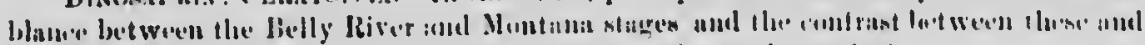

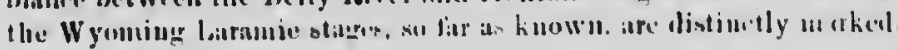

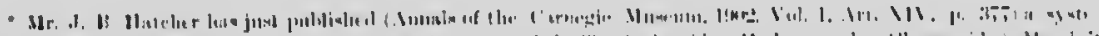

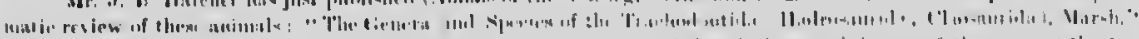

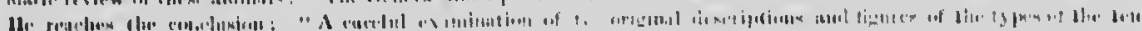

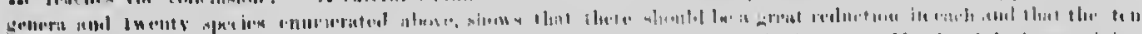

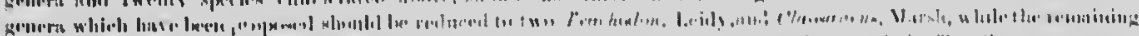

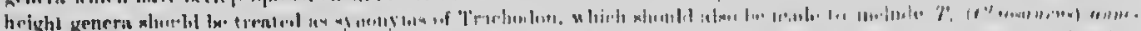

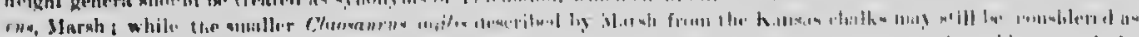

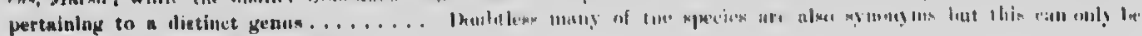

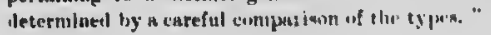


The tyme anderatare distributed treographicully as follows :-

\begin{tabular}{|c|c|c|c|}
\hline Mostaxs. & 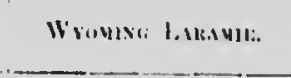 & 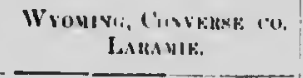 & Cin.orsino. \\
\hline Monertonius, Copser. & Agrtllikumins, Cink. & Tricurneops, Marsh. & Polyonax, Cippe. \\
\hline$\| y<z:(n) 4, \quad$ " & (Cretneous No. 6 or 7 .) & Trinsituris, " & \\
\hline Cirotepr, Mash. & & 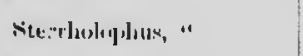 & \\
\hline 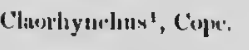 & & & \\
\hline Manowpmulylu*, " " & & & \\
\hline
\end{tabular}

In creneral the contrint in the Ceratepia is as follows; future discovery may alt these previaling 'haracturs :-

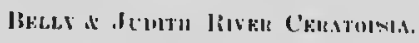

Of muiller size.

Nasal loorus very labge.

Sinall frontul or supriurloitnl lorus.

Widely open suprateinporal fossal.

Tretl single (? Momorlomius) and double fnnged.

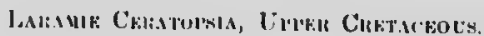

(If litliner size.

Nisal lotus rulatively smaller ('T'ricurahos) or es restigial.

(ireatly developenl froutal horn.

Supratemporal forsa" open (Torosaturus) or nea closenl (Tricerntups).

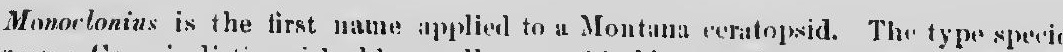

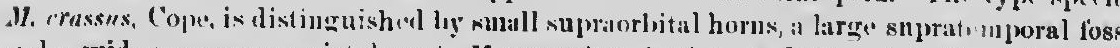

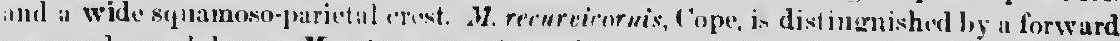

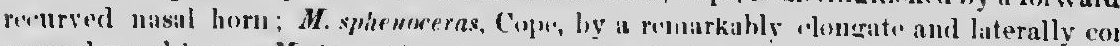

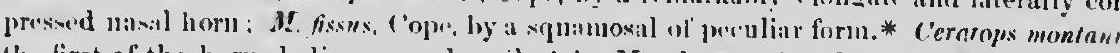
1h." first of the hormed diunsaurs described hy Marsh, wis found on the Missonri rir

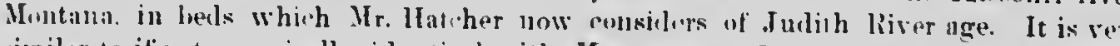

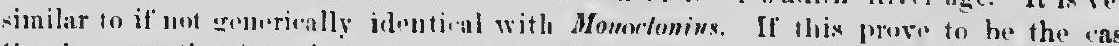

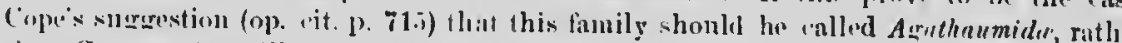
than Cerulopside will desers" consideration. The apparently new species $\boldsymbol{M}$. Inwsol M. ronalensis, and Al. belli. distosered by Mr. Lambe in the lielly liver series, adol the variations in the Ifomorloniws tyju. of skull in the Mid-Crotacrous.

It will lwe observed that five of these spenties are known to possess larew nastl and am

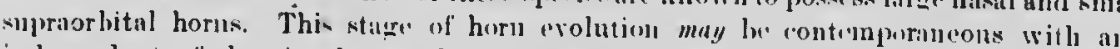
inclependent of that in the sonthera laramie dinesanrs in which the nasal horne a

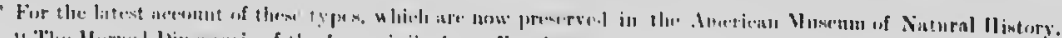

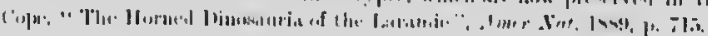


iuvariobly smaller than the linutal horns, but "oupled with the suatler vizu and open temporal fossic, it would appear to be more primitive.

The mew genus Slesoceras, proposed in this mingoir, may reprenent a type with amall nasil horus, a in soine of the Laranie Ceratopsids, such as Sterrholophus.

It is not at all inprobable that the horned dinosinus will prove to be diphylutie, one lino with persistent open lossiv leading from Monurlonins to Torosianes, the other lealing to Triveralops with elosed losmie.

\section{MAMMA GIA.}

(1) the two Mamonals distorered in the lielly liver, Plitodus mimeres, juldeing hy the andition of the grooses npon its premolars ated tulnereles npon its anolar teeth, is undoubtedly more primitive than the Laranie plagianlacids.

\section{Gexerat Coxcuugion.}

The conclusion is that the lielly liver lama is moro nu. ient in chararter beth as to the older types of animals whith it contains and as to the stages of evolution anome auinals which are also represinted in the Laranie. The gevlogical interval represinted by the Ft. Pierre-Fox llills marine beds was alenupanied by the extin.tion of "ertain Inraskic types and progressive evolution of the prersistent lypes. linally the tossil vertebrates hitherto desicribed from Montan: [ probably are, in part at least, of Mid-('rulan... ous or belly River age.

\section{A merican Mlshum of Natrrat. Hintoly,} July 2i, 1:40? 


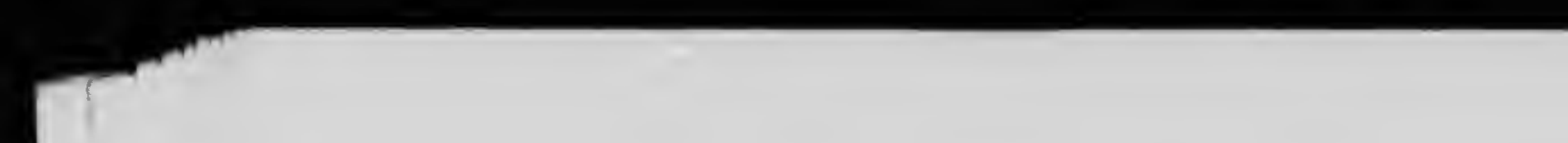


GHOLOGICAL SITRVEY OF CANADA.

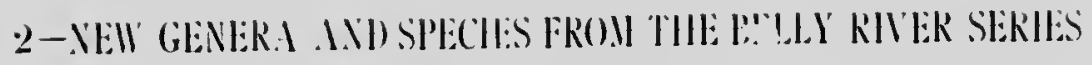
(III)-CKI:TICE()L'S).

II.

I. I WRENCE M. LAMLE.

23 


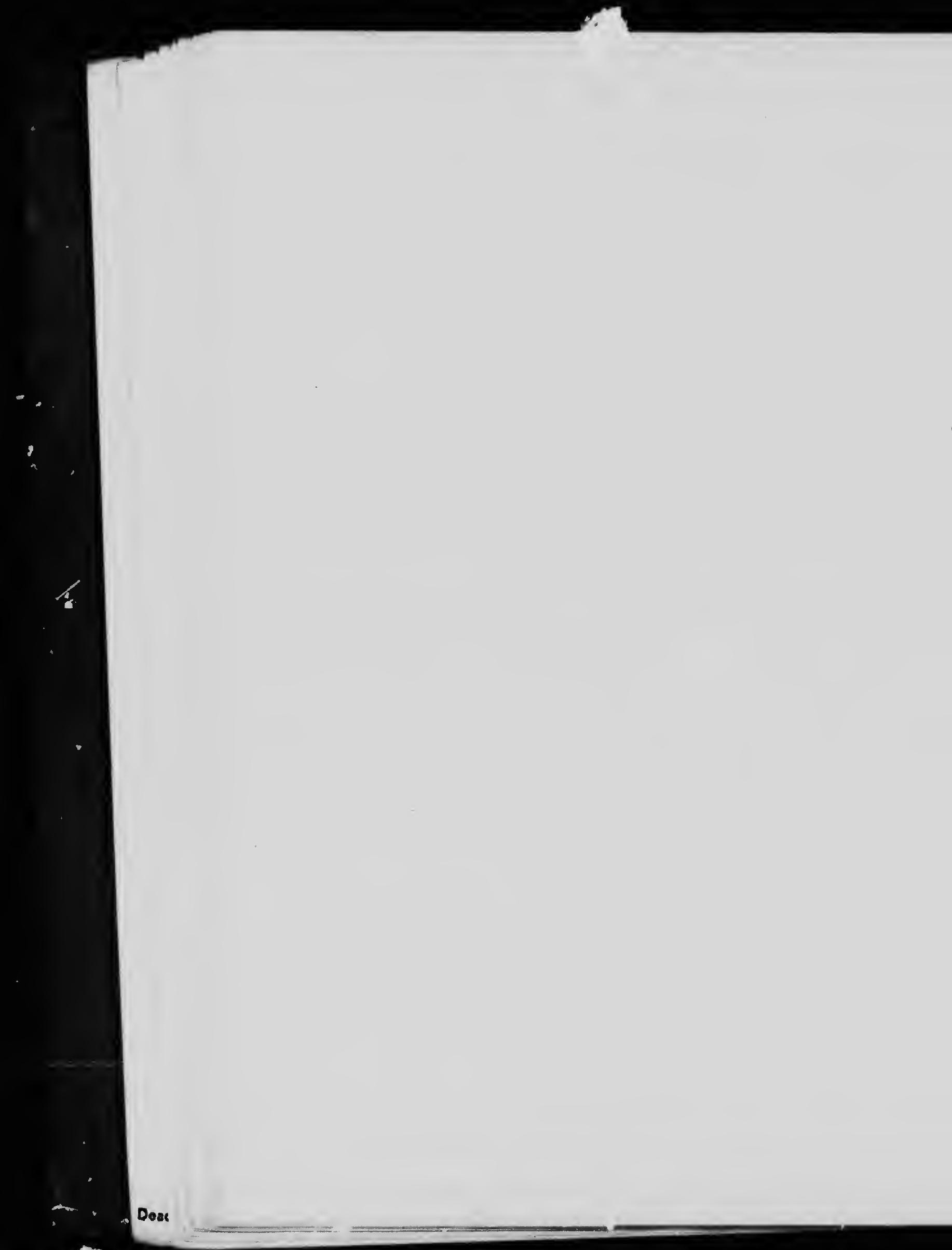



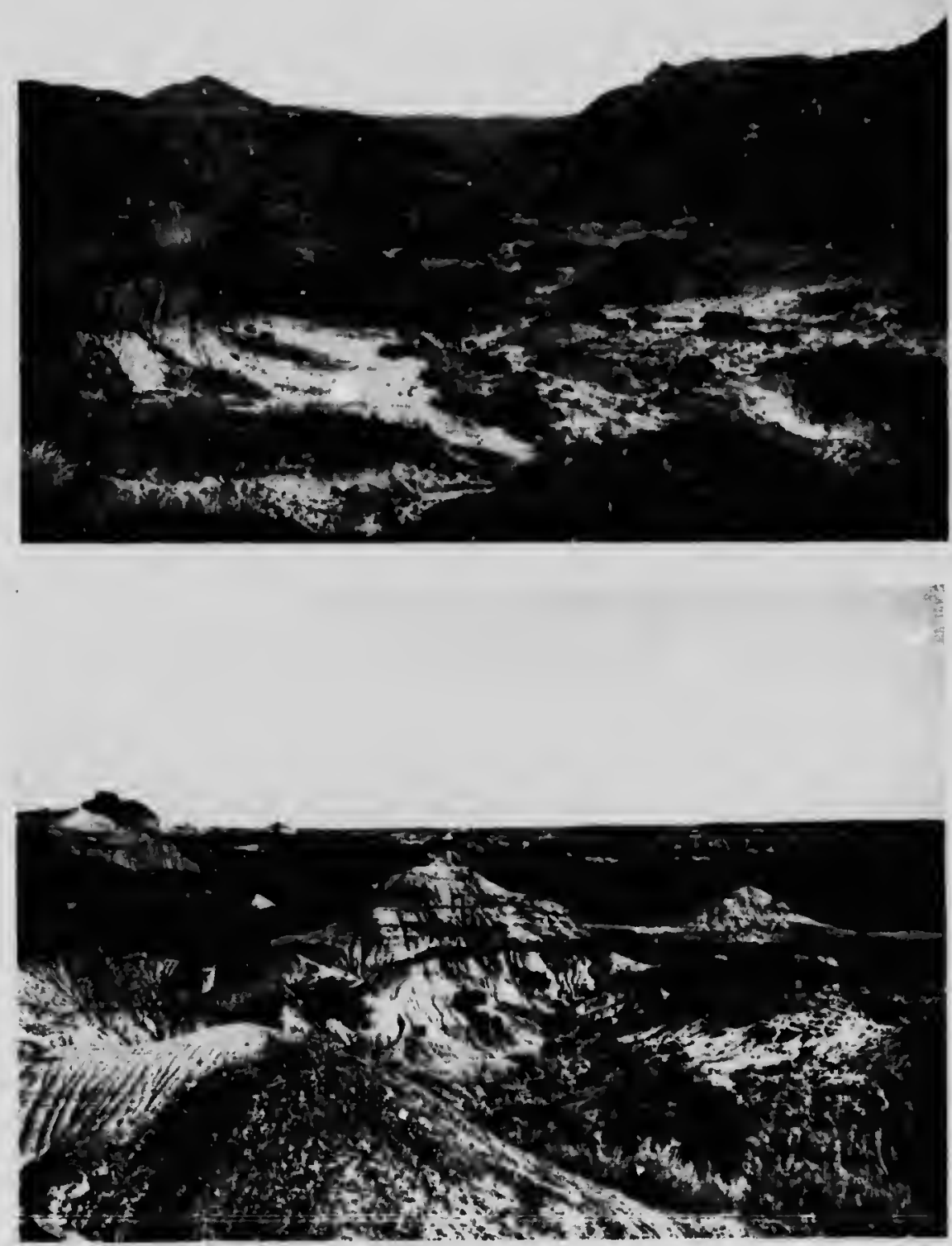

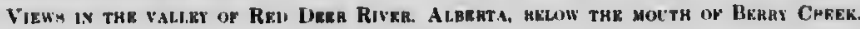




\title{
GEOLOGICAL SURVEY. OF (ANADA
}

\author{
2-NEW GENIBRA AND SHECIES FIROM TIE IIBLLY RIVlili SliRILS \\ (MID-CliETACliolis).
}

BY LaWRENCE M. LaMne.

The present report consint of descriptious or datirminations of vertobrat" remains, from the Belly River series of the Crota'sous, inlle ted by the writer during the summ.rs of 1897,1898 and 1901 in the led ber rivor district.

The species represented in these collections belong for the most part to the class Reptilis.

In 1897, the writer descended Red Denr river, starting from the village of Rind Deer, and made collections from the Edmonton subdivision of the Larumie, between Red Deer village and Willow creek, and from the Belly River series between Bull Ponnd creek and Dead Lodge caîion.

The results of this expedition fully realized the belief of Dr. George M. Dawson, Director of the Geological Survey, that a systrmatic collection of the dinosaurian and other reptilian remains, that were known to nccnr sbundantly and in an excellent state of preservation in the rocks of the Edmonton and Billy River series in the ricinity of Red Deer river would prove to be of scientific ralue and interest.

In this year, however, it was found that the best resnlts were obtained in the Belly River series, in the vicinity of Berry creek. Accordingly this locality was revisited in 1398, and again in 1901, and collections made from the Belly River suries only, in an extensive area of "bad lands" on either side of led Deer river between Berry creek and Dead Iodge caňon.

To Dr.G. M. Dnwson, Mr. li. G. McConnell and Mr.J. B. Tyrrell principally, belongs the credit of having elucidated the geology of the Cretaceons and Laramie rocks in the region extending from Milk river on the south to north of Red Neer rirer, in which region the Belly River series has an extensive development, its bonndary haring been traced for over 150 miles in underlying contact with the Pierre-Fox Hills group, with abundant and - elusive proof of the subordinate position of the former to the latter.

Mr. J. B. Tyrrell, in his report on the geology of northern Alberta,* dirided the rocks of Laramie age, overlying the marine Pierre-Fox Hills group, into a lower and a

- (ieological and Natural History Survey of C'mada, Anmunl Report, new series, vol. II., part K. I

4 
higher sublirision, which he callod ropertirely the Filmonton nul the Paskapon acriew

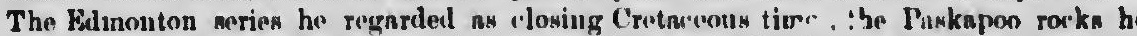
consilered as the reprementativen of the beginuing of the "ertiary "porh. The l'anknpo serion in a fresh-water deposit, the Edinonton merios is of i ruckinh water origin.

(Of the Belly River neries J)r. Dawnon writes :- " in the revion of the How and Boll riverw, the Piorro is mulirlnid by an extonsive frenh and brackish-water serios, consistin of sandy argillites and and the low'r generally darker and yellowish or brownish. This has been callod tho Brll River mories, and aplwarn to correspond previsely to that oncupying $n$ similnr stratigra phical position on the Peace river, and there designated the Dnnrogan series. Ther indiante tho existence of a prolonged interval in the westirn Cretaceoun aren, durin which the son was inore or less cxcluded from the spion, and its plnew occnpiod for lont periods by lagoons or fresh-water lakes. Below thene, both in tho region of the Bow an belly and on tho ['ence rivers, is a wownl series of dark shaloy which may probabl repreant the Benton gronl of the Missouri sections."

The approximate maximum assertained thickures ol the seri:n, acording to $D$ Dawan, $t$ is 1110 fort.

The sane authority, in describing these rooks, remarks, that "the separation of th lower, or yellowish and banded portion of the Belly Rirur nicrice," from the npper o pale part, "is made merely lor convenin'nce of duscription, and is prohably un wnrranted in nay other sense. The distiuctire characters of the two portions of th series are indoed so inlefinite that though little hositation might be felt in relegating giren large exposnre to one or other, the points of difference ranish when any attemp to drnw a precise line is madi.".

The following section, as seen on Fossil coulé, in tho Milk rirer district is regarde by Dr. Dawson $\|$ as a reprosentative one of the upper or lalo part of the serios; the bed in descendingrorder are :-

\begin{tabular}{|c|c|c|}
\hline & Fert. & Inches. \\
\hline Dark gray, soft, aandy clay. & i & 0 \\
\hline Yellowish sand or soft sandstone. & 4 & 0 \\
\hline Gray, soft sands, with some Inndels of cluy $\ldots \ldots \ldots \ldots \ldots \ldots$. & 15 & (1) \\
\hline 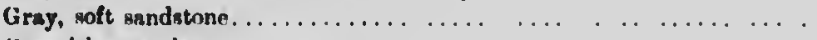 & 1 & () \\
\hline 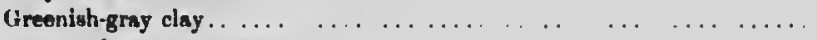 & i & 0 \\
\hline Gray, soft, shaly sundutiulie. $\ldots \ldots \ldots \ldots \ldots \ldots \ldots \ldots$ & 1 & 0 \\
\hline Gray, soft, sand and sandy clay $\ldots \ldots \ldots \ldots \ldots \ldots$ & 4 & 0 \\
\hline (ireenish-gray elay........... & 5 & 0 \\
\hline Nodular layer of impuse calcureous imontone & 1 & 6 \\
\hline Yellowish, fine sand, or soft sandstone..... & 4 & 6 \\
\hline Dark gray, sandy clay $\ldots \ldots \ldots, \ldots \ldots \ldots \ldots \ldots \ldots \ldots$ & 3 & 6 \\
\hline 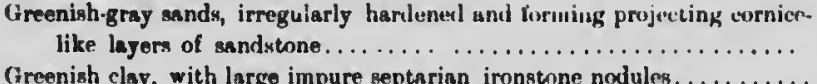 & $\begin{array}{l}8 \\
8\end{array}$ & $\begin{array}{l}6 \\
0\end{array}$ \\
\hline
\end{tabular}

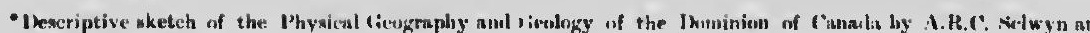

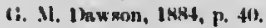

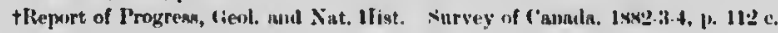

$\div$ Ilisl, p. $117 \mathrm{e}$.

1hill, p. no c. 
pon antips. rorks he l'askapon

and Bolly consinting In in tint, tho Brlly - stratigraes. Theso en, luring d for lonk Bow and y probably

ne to Dr.

tion of the npper or hably not ons of the legnting a ny attempt

regarded the beds

Inches.

0

0

(1)

(1)

c

1

0

0

(

6

6

6

C. Niwynanil

\begin{tabular}{|c|c|c|}
\hline (Irveluial'.kray, sandy clay" an! clayw. & Five. & Inclu's. \\
\hline Yollowinh-umy, nanily ciny, with layer full of muall ciny joldblen ut wip) .. & 111 & "1 \\
\hline Yellowinh-gray, fine, noft mamil $\ldots \ldots \ldots \ldots \ldots \ldots \ldots \ldots$ & ; & () \\
\hline 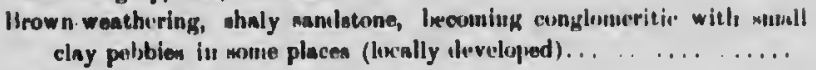 & l & ii \\
\hline 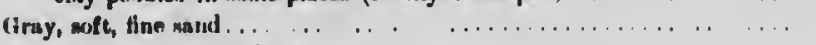 & 3 & 0 \\
\hline$\ldots \quad \ldots \ldots \ldots \ldots \ldots \ldots \ldots$ & 1 & $u$ \\
\hline 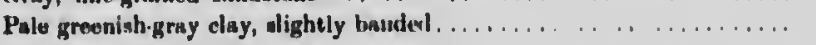 & $\therefore$ & "1 \\
\hline 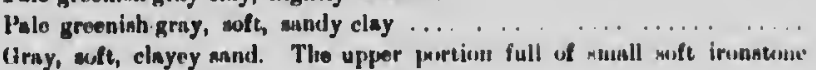 & 4 & i \\
\hline concretions..... $\quad \ldots, \ldots \ldots, \quad \ldots \quad \ldots \ldots, \ldots \ldots \ldots$ & 3 & 0 \\
\hline 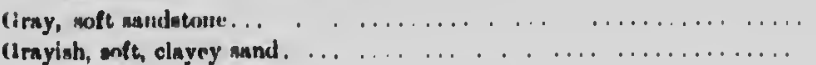 & 0 & 2 \\
\hline & IT & 2 \\
\hline
\end{tabular}

In the Red Dewr rirer district the upper bels of the siries are represented, with frobably the npper part of the lower beds. They ionsist inainly uf, tron ahout 200 to 400 feet of alteruating soft, light gray, ilayey sumlstones und grayixh aud dark 'liys with thin beds of ironstun. and layers of ironstone nodules. "hick beds of yellowish sandstone also oceur near the base. These yellowish sandstones uppear to be at about the dividing line botween the npper aud lower portions ol the surion.

The Belly River series is correlated hy Dr. Dawsoll with the Jnditl IRiver series of the Missonri.

One of the tirst reports, if not the first, to appenr on reptilian remains from western Canada, was tbat of l'rofessor F. IJ. Cojw" which took the form of un appindix to lir (F. M. Dawson's " Re'port on the (ronlogy and liesour.es of the' forty-ninth parallel " issued in 187i. Profeseor Cope here den:ribnd certain dinosuarian, chelonian and lish remains from the " Fort Uniou group" of Milk river.

Since theu, refirence has bern minde, from time to time in the ruports of the Geologinal Survey, to the discovery of reptilian remuius in the larance and thelly River serien, at varions localities in the north-wost. Unfortmuatoly, the collectinc ol aneh romains has not been systematieally nndertaken and, exiept in one instunce, no detuiled report has appeared on the oecusional remains of reptiles brought from the west, that exiepition leing the deseription giren by l'rofessor ('upe, + in 18!12, of two skulls of Lalaps iurrnssntus, obtained in $1.88+$ and $1 \times \times 9$, hy Mr. J. I. Tyrroll and Mr. T. C. Wiston, resprectively, on Ked Deer river, from row ol the Edmonton series.

On' of th" ehief dillionlties, encount'red in stndying the remains of the dinosaurs and other reptiles from the Red beer river district, arisi's from the linet that the bonew are generally very much srattered, separate bones of different spu'ies oce urring toguther, the finding of a number of bones, of one individual, in thrir nutural relative position to each other heing raro.

As a rule the boneg arc weli preserved but very lraurile, so that the greatest care is requisite, and sperial precautions nuessary, before their renornl can be attempted.

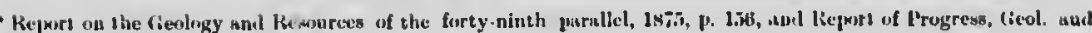
Wat. Hist. Survey of Canaila, 18\$2.3.4. p. 119 c.

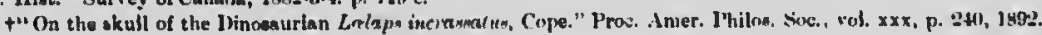


The writer wishen to asknow lodere the asalstance rondered to him, by J)r. t). I'. Hs of tho Amorlean Mlumun of Natural Jlislory, who by the "xprewsion of his vfows regat

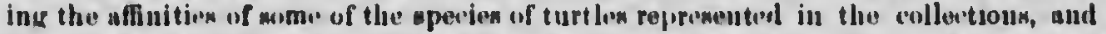
other courtekien, arrestly fim ilitated the work connentod with the determlnutlon dewcription of these interonting roptiliew.

In 1801, Mr. L. Hober Cole, of Montrual, atted as aswistant in the felel, and contrilont materially to the su. coms of the ixpedition of that yoar.

The writer is parti'ularly indibtenl to l'rofeneor Itenry Fairfleld Ostorn, Curator tho Department of Vertebrate l'uliroutology ol the Anerican Museun of Natural Himo New York, for his eo-operaiou in the stuly of the mtrueture, eyetematio relation a

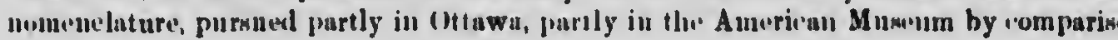
will the extensive Cope collertion.

\section{PISCES.}

Mrteibalilun, Cojm.

Mitedalies mipartitus, Cope.

llate XIX. figs. 1 and 2.

Myderhyphus bipartitus. Coppe. INiti. Proc. Acml. Nat. Shi. Philatut., p. 260.

This speries is reprexentel by inany tuth fonnd marato in all ran'k. Their var tion in size is ronsiderable, the sunallest umasuring about $2.5 \mathrm{~mm}$. on the long dianeter of the crown, whilst the largint collected has a diameter of $9 \mathrm{~mm}$. in tho war direction. The proportions of the majority of the nperimens are nearly constant. Menull

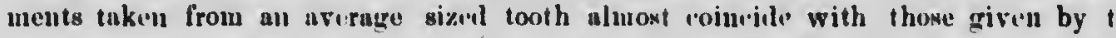
inthor of the xprios in his original descrijetion. In the majority of the sperimens erown is irregularly striated in a direction at right angles to nud on botla kiles of 1 line dividing it into halves alihough geuerally one lialf has fewer striations than 1 other. The 'rowus of some of the terth are smootleer thati those of others, a dillieres Iue probably to age.

Mearnementa of an ureragr: wised tonth.

Length of uneth........ . . . . . . . . .

the timeter of ruwn ....

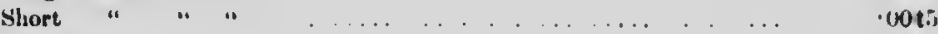

Length of rovt.... . . . . . . . . . . . . . . . . . 10030

Long diameter of root. . . . . . . . . . . . . . . . . . . . . . . .

Short "

Belly River series, Red Derer river, $189 \%$ and 1401.

1)r. G. M. Dawson rollected a number of specinems on B.lly river. N.W.T. (Non. and 41), ili 1881, and Mr. Wexton sperioneus in Irviur ('oulér, urar Irvine station the line of the C.P.R., in 1888. 
(1). I'. Hay, tew regrard. oum, and by ination and

contributiol

\section{Cinrator of} iral Ilime ory, Intionn und tomparinu!

Their variathe longer in the man" t. Measuri" ven by thi maimens the miders of the mo than the a diflierene's

I.

Urisin

Our:

vos:

1030

0042

0030

T. (Nos. 40 station on

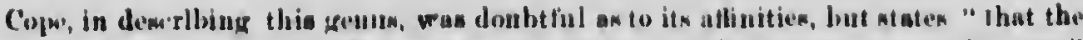

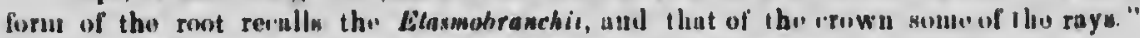
The type be revordid an from the Fort Union breln of Monians.

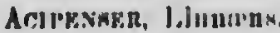

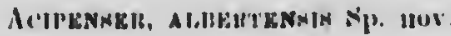

l'ate XXI, fig. !!.

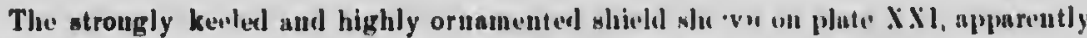
repreants an anciest stnrgeon, for $w$ hich the alnve mune is oprosed. The ornumenta. tlon consiste of ronuded, conleseent ridges and nodes in high retivf, and qulte smooth, not very unlike the sculptured anrface of the shell of some spreies of turtles.

This genus han not hitherto been known lrou rovks lower than the 'Tertiary.

lally Liver series, lied Deter river, District of Alberta, 1:101.

\section{lokipipurris, Aganкiz.}

\section{LEMDTTE OCOIENTAI, laU,}

l'ute XIX, lig. 8.

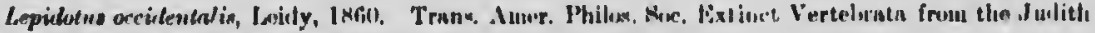
Hiver and Grent Lignite formations of Nihrowk al, pl. 11, tig4. 20.23.

Numerons acales, from the "bad lands" of Rud llew river, uri" mpparently not distingnishable from those dencribed by leidy nuder the nasac lopilotes orridentelis.

The acale figured is fairly repress ntative of those in the rolle tions, as regurels form and wize. The lozenge-shap'd, s'numelled outer surfare is sunooth and whing, with generally a few sunall, phucture or pit-like defrensions nenterenl townel the centre; at few growth liues are geuerally ubserved parall.l to its edge. Idingth of mpee imin figured is:i mm., greatest thickuess $3.0 \mathrm{imm}$.

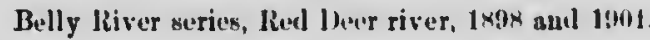

Similar seales were collected by lir. (i. Ml. Dawson on liclly river. N.W.T. (Now. 40) and +1$)$, in 1881, and by Mr. T'. ('. Weston, at liosm conlex, near Irvinte on the line of the C.l'.1R., in 1884.

\section{RHiNeastes, Cope.}

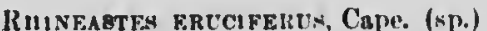

Cerntorlus enceiform, Cupe, t87ti. Proc. Acal. Nat. N.i. Philadel., p. Lits.

A number of fragments of eranial bones are referred to this species after comparison with the type from the "Fort Union" beds of Montana. The sculpture consiats of strong 


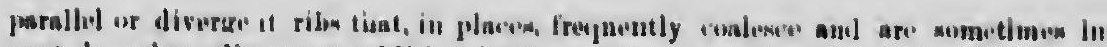

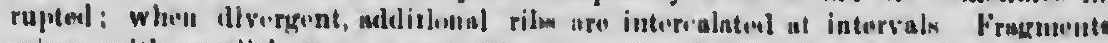

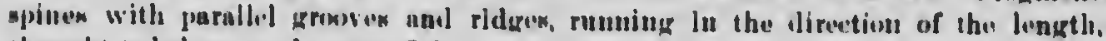
thonght to belong to the sume finli.

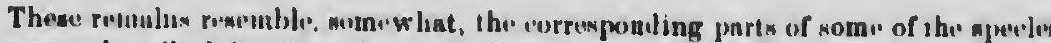

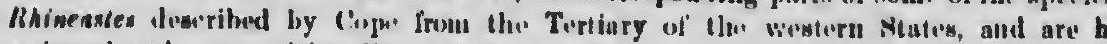

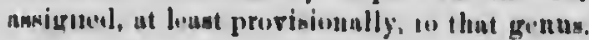

Belly liverer mories, lint there river, lonl.

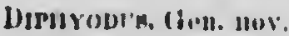

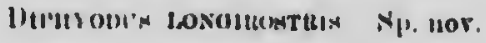

Plul, XV., ligm, 18 and 1:1.

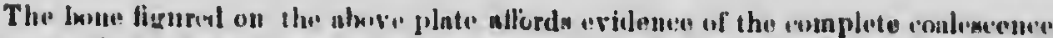

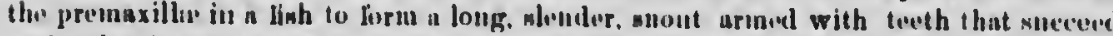

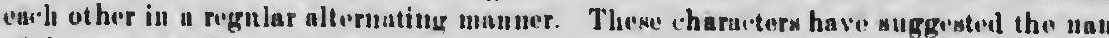
of the genun and sperites proposed.

Tho sperionen in in the liorm of comparatively thick plate hent, on itself, so as to U.shaped In transverme sention ; it is imperfee't at both ends, is $23 \mathrm{~mm}$. Iong, tapers aligh towarcl the front, and is $4 \mathrm{~mm}$. broad posteriorly und $8: 5 \mathrm{~mm}$. brond at its unterior There is uo evidenc" of a modiun longritudinal nuture. The sides of the hollow semincyl

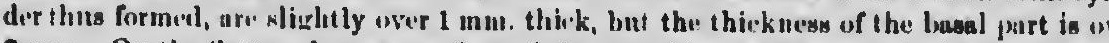

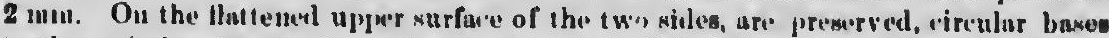

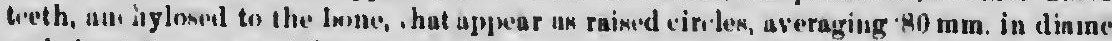
und alont a um. upurt from centre to centre. (1) the right side there are nine teeth rep

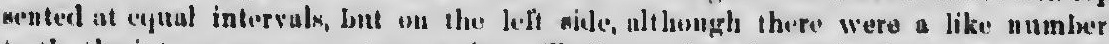

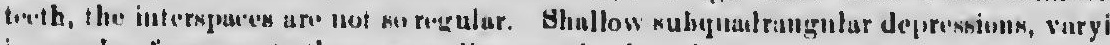

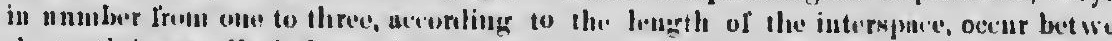

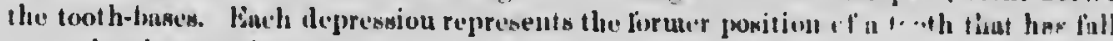
ont or hus beecu broken oil:

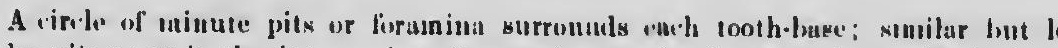

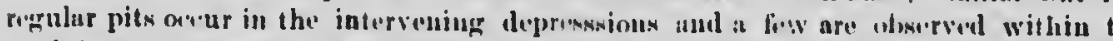

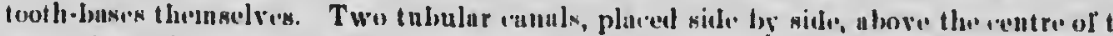
bass, pierre the bone lengitadinally throughout its length. The bot tom of the medi groove between the i wo row of lenth has an undulating surfuee. The sides and round bast: of the bone ure smonth and show irregular longitudinal lines of small pit.li nuarkings. One of the tooth-bases at the posterior end is deridenlly suhquadrangular oral in shape with its larger diameter transperas.

Two or three frogunents prewent the same "hara'teristics of structure.

llelly liver serien, Korl Deer rive:, 1!m1. 
"t]mon Inter. rmaruivite of " longtli, are thi' sperellew of anil are hero

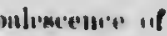
al xilcerimlint if the wane:

Il, no ase tolue jwrs slightly uterior mul. v semi-cyliin. part is iverer Ini baves if" in dinmetur teetli repro. a minber of ans, vinying ellir betwenll ut has fullou

lar lint lons within the ent ro of the the Inealim aud ronuther nall pit-like trangulnr or

\section{Ii.l'Ti.IUHI.}

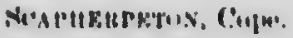

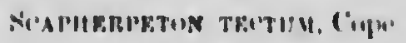

Phit, II! fign. 4-x.

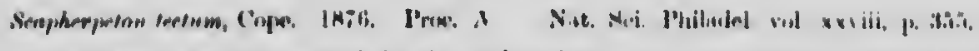

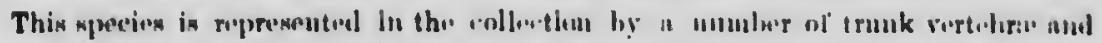

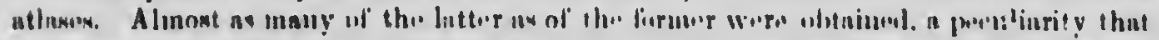

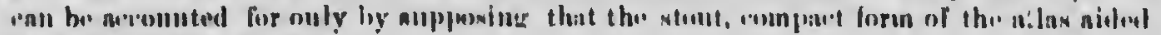
III maving it from lirenknge.

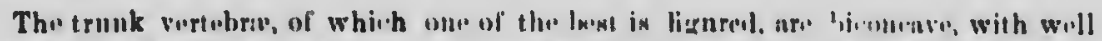

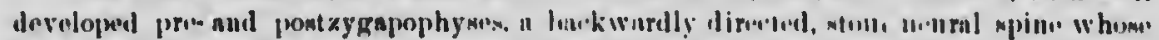

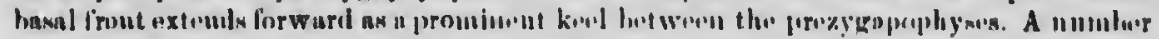

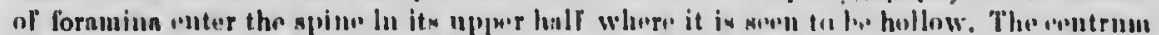

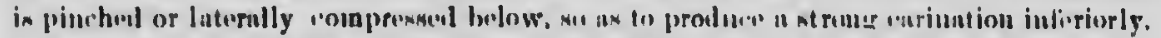

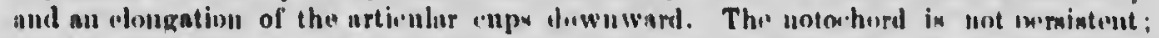

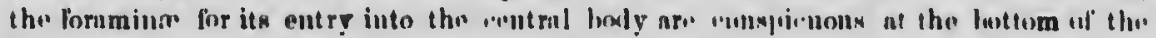

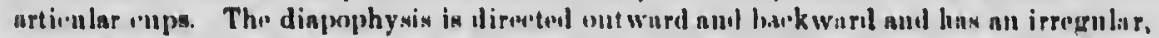

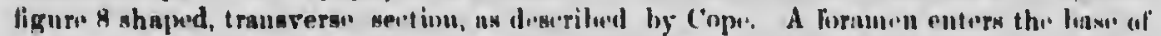
the diapophysis from in l'rout, anotleer from lwhiml aul, on the right side of the vortolorn

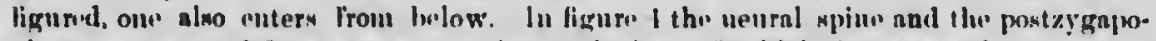

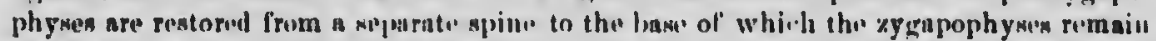

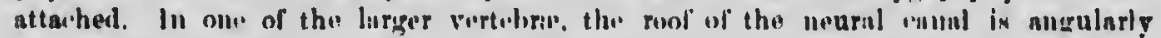

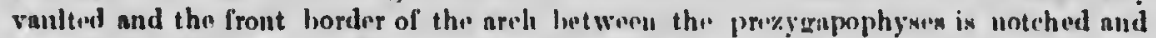
turned aliehtly upward. Numiruas small lorumiun ociur iu ull parte of tlw vertiobre.

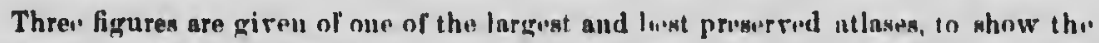

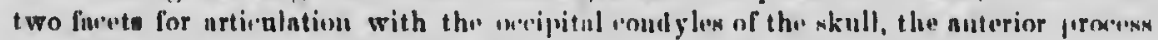

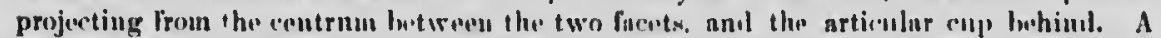

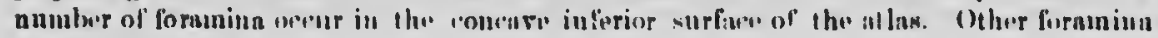
ocene the depiotinl.

\begin{tabular}{|c|c|}
\hline \multicolumn{2}{|l|}{ (1) trunk vertebra: } \\
\hline ()f trunk vertebra: & .11. \\
\hline Iengtli of centruin & $\cdot \cos$ \\
\hline Hright of articular cups... . & $\cdot 00 \%$ \\
\hline 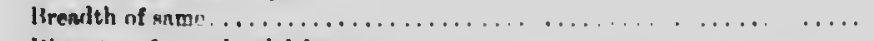 & $\cdot 100.1$ \\
\hline chorilal fornineur $\ldots \ldots \ldots \ldots \ldots \ldots \ldots \ldots \ldots$ & $\cdot$ nol \\
\hline \multicolumn{2}{|l|}{ 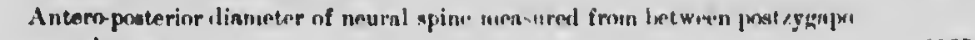 } \\
\hline 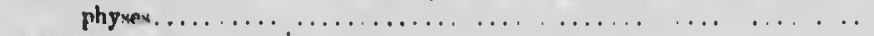 & .0035 \\
\hline \multicolumn{2}{|l|}{ Of ntlas: } \\
\hline Fxtreme length..... & $.00 \overline{-}$ \\
\hline Fxtreme hreaultlı, $\ldots \ldots \ldots \ldots, \ldots \ldots \ldots \ldots \ldots$ & 0095 \\
\hline Height of tacets for articulation with mondylm of akull $\ldots \ldots \ldots \ldots \ldots$ & $\cdot 1003$ \\
\hline Itrendih of saute $\ldots \ldots, \ldots \ldots, \quad \ldots \quad \ldots \ldots \ldots \ldots \ldots \ldots$ & $\cdot 004$ \\
\hline Height of arlicular cup $\ldots \ldots \ldots \ldots \ldots \ldots \ldots$ & $.003 i$ \\
\hline$\ldots \ldots \ldots, \ldots \ldots, \ldots, \ldots, \quad, \quad \ldots$ & 003 \\
\hline
\end{tabular}

Belly River sioring, Rond llwer rivor, 1 ! 111. 
Thr position of this gems was unt delinitoly defermined, hnt its author consid that the structure of a proximal limb houe, and the form ol the diapophyses ol the v bri' refer" \& "ith umch probability to the Urolela, and that the biconenre ce

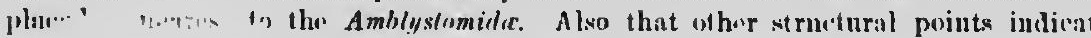
lian is it lliamol is a any of those now living.

A

¿n. maxilly of whi.h, two virws are giron (plate XV. ligs. 1i and 17) intorest. It is almost perlient ulferiurly. Its upper borler "omes to a sharp ielge, which posteriorly a small frarment has ben broken oll, as indiented in the liguro ridge extends the length of the hone on thr inner side at about mill-hright at the "e hut curving downwaris to near the lower ningin in front. Pusturiorly two sutural

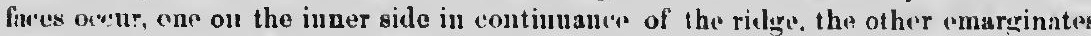
upper horder. Betwen theso two surfaces the bon is shallowly exiavated. Six formmina o'cur in a line at about onid-height in tho anterior half ol the outer sur Th. lower borlor of the inaxilla is broal and he:ers eight subcuadratoly olliptical to hases with their greater diametors transwerse to the longth of the jaw. Small formu openings occur encireling the outer surface of the tooth-bises. Treeth have been lost the jinw leaving shallowly depressed interspares.

The relationship of this Inur is not rlearly understool, but it is for thr prenent riatid with Srapherpeton tectum. It incurrol with and is of the simme roulour amel tux as the vertohrae of that speries.

\section{REPTIT」A.}

\section{SAURUPIERYGIA.}

\section{PLINIONALUIDA.}

C'motianaturs, Leidy.

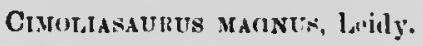

Cimolinasurua mngmus, Jeilly 1852. Proc. Acml. Nat. Sci. l'tilmkl., vol, v, p. 32., and ilid, wh. vii, p. 72, pl. 11, figs. $1-6$.

Cimolinanurus magnus, Leidy. 1865. Cretaceous lieptiles of the United statev, p. 15, pl. v 13-19 and pl. v1, (Ámithsoninn Contr. to knowledg", vol, xiv).

Fourten corrival vertohre, lonnd withiu a limitol spane and prohably luelongin one individnal, are referred to this speeins; they lorm a toleribly complete sorios wi gradual increası in size from frout to back.

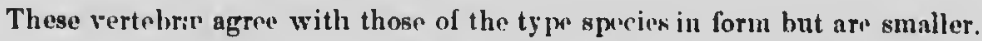

The centra may be lescrihed as shorter than broal, with concaves siles and I

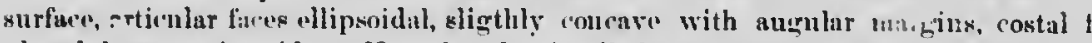
placed low on the sides. Neural arrhess in all the sperimens, broken off, "xinpt in apparently a hate 'orrical, in which the basal part on one sicle is preserved, showiug 
hor "onsidered st if the vertisonense rentra its indivinded al

(1) and 17) is of arp relge, from the tignre. A $t$ at the reutri o situral surnaririnates tho ad. Nix largo outer surface. lliptical toothaall foramina! been lost from ur and texture

, and iluit, INist p. $25,0,1, x, f i g s$ Imlonging to serises with a

inller.

des and lower 2. rostal fincet exi'rept in olle, , show:ing the height of the neural rallal. The bases of the ribs still remain in a fiw oases. In the silpposed late cervienl, the costal furet extends upward on to the b.tse of the uenral areh. Two large foramina, placed one on either side of the median line of the lower surfine and scparated by a low ridge, are connected with a pissigere that opeles into the llenril "anal by two separati apertures. The nenral ranal is alwht is high is it is wide.

\section{Meuxurrmeu/s.}

A sinall vertebra from anterior en ' of series :

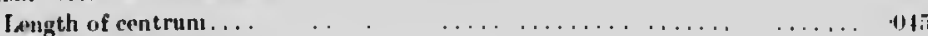

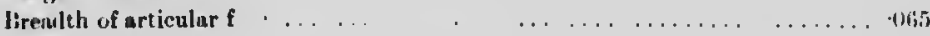

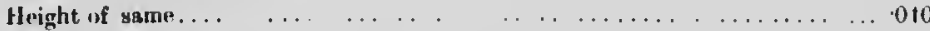

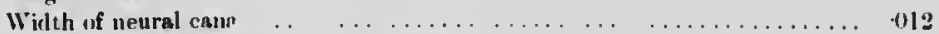

A larger vertebra froin pos "i in ind of serats:

Length of centrum ... $\ldots \quad \ldots \ldots, \ldots \ldots \ldots \ldots \ldots \ldots \ldots, 0.11$

lirendth of articular fue. $\ldots \ldots \ldots \ldots \ldots \ldots \ldots \ldots$

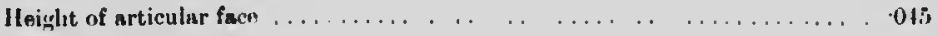

Wiulth of neural cartal . . . . . . . . . . . . . . . . . . . . . . 01:

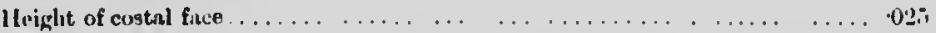

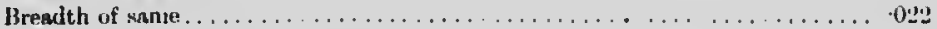

According to Cope, Discosaurus is sperifically identical with this genus, Whilst under the generie nane Cimoliasaurus, Lydekhor* his included Brimosaurus, Leidy, and Elusmesaurus and Polycolylus of Copes.

Belly River sarios, lind Jeer river, below Burry croek, $18 ! 1 k$ and 1901.

\section{CHELONIA.}

THIONYCHII) A.

Trionyx, icotliroy:

TrIONYX Foreatus, Leidy.

Mate l, ligs. 1 and 2.

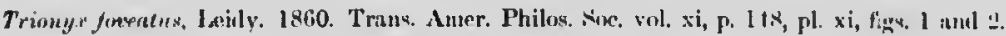

" "Iaulle. 190\%. (ímol. Survey of Canidia, Sumuary lieport for 1901, p. R1, pls. anil 11 .

Trimny: foneatws was originally diss'ribed by Lidy from small fragments of costal and stermal bones from the Judith liver beds of Nebraska.

A carapace, from the Belly liver series of the Red Deer rirer distriet, lacks only the unchal plate, which unfort unately was missing.

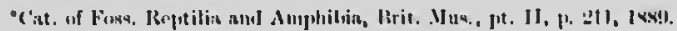

- 
This arapace (tig. 1 ) is a littl. broader than long, and is only slightly mo

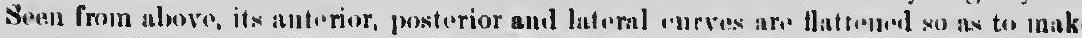

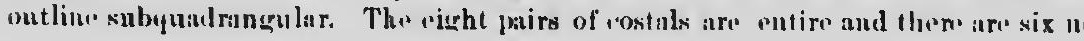

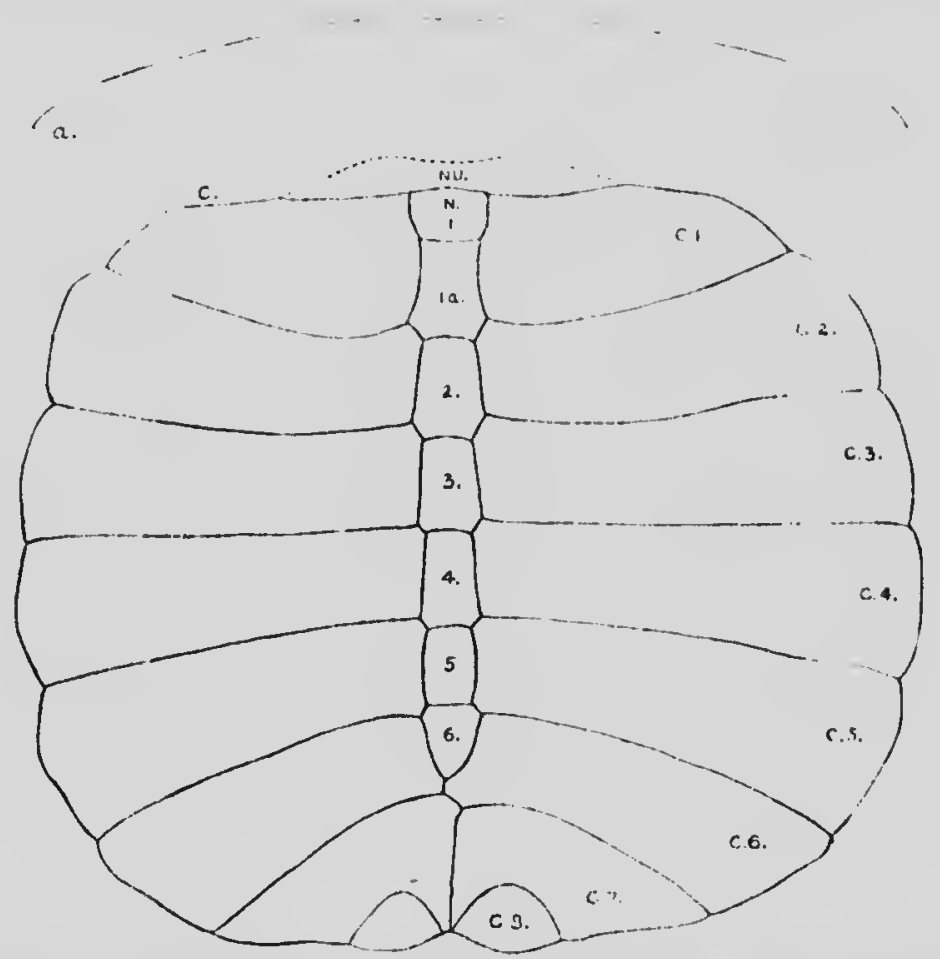

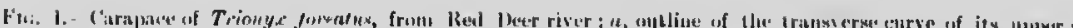

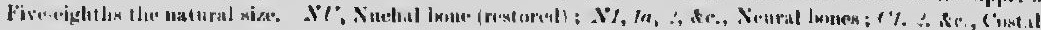

bones of whirh thr anterior one is divided. Neural 1 is broaler than lone with "o sides, neural 1a is longer than hroad, broadest mour its posterior and and has ion nides. Neurals 2, 3 and 4 are six-sided, nenral it is oblong, and ueural 6 , lying for most part betwe'en the sixth custals, is shield-shaped, narrowing to a point behind. seventh costals are suturally united at their inner ands, where they develop a bri sufficient to separate the eighth "ostals from ea.h other. Thesi last are subtriaugul shape, with three convex sides. The nuihal plate was revidently small, as the la tornination of the suture ( 9 , in ligure 1) botween it and the first costal "ates a side "xtension not far past a point in alvance ol the mid-lenget h ol' the first "c its lateral ends lie benleath the front border of the first costals and are not seen alove. 
ightly monvix. an to inikit that :Iri six nouril

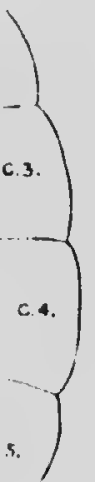

it* "ipker surficer.

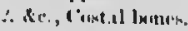

with ronvex id has conl'nve lying for the t brhind. The alop a britadth ibtrianerular in as the lateral costal indihe first rostal ; - not sien tron
Simall, shallow, rounded deprossions mark the surfure of the mourals and the imer "uls of the instils. In the lutter, as the distunen from the uenrals increases, the depressions gralually grow harger and mere decided, benning often renitorm or ovil, anel frepuently roaleseing, nutil in the distal ends of the rostals a few anore or lessis rontimous furrows ar lormed parillel to the outer unirgius of the plates. These furrows are a collspicuous feiture in the seulpture; they are not no well Intrked on the posterior

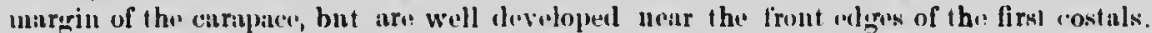

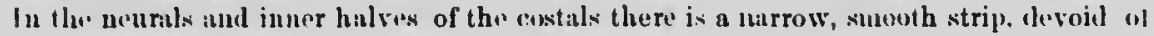

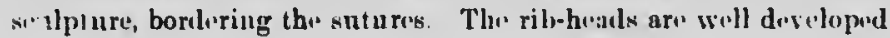

\section{Mrosurmments.}

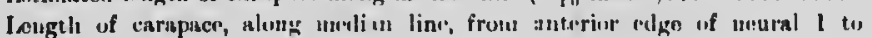

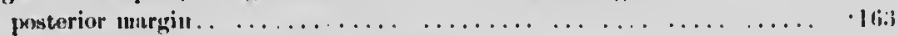

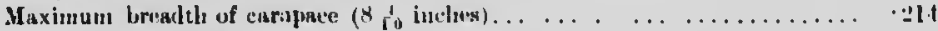

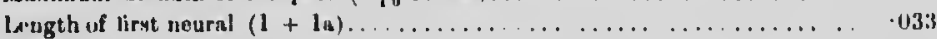

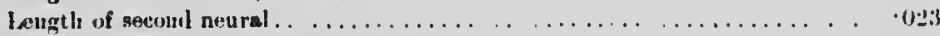

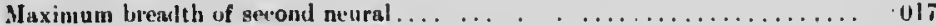

Thickness of fourth costal at centre nenr imer emul. . . . . . . . . . . Wh

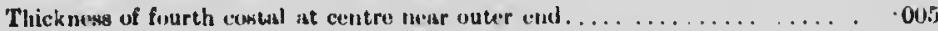

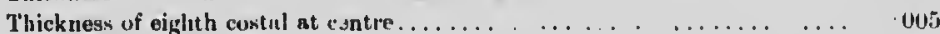

The hyosternal and hyposternal holles of this species, shown in fir. :2, page 3t, belong to individuals of larger size than the one represented by the carapare. The missing parts in lig. 2 are restored from a number ol other sperimens in the iollection, of which no two are exactly alike. The sculpture differs ansiderably from that of the "arapine: and is shown on plate 1 , fig. :-

lielly hiver series, lied Deer river, 1901; also uunerous rostal lones and fraginents of the eirupace with separate nearal bones as well as hyoplastra and hypoplastra and bones of the undeskeleton, 18:17. Is!18 ind 1!01)

Dr. G. M. Dawson eolle'ted fraguents of the carapate on linlly hiver, S. W. T. (Nos. 40 and +1 ) in 10

Triomyx plenew,**.

1) bell, a liritish Lower borene sinedies, deserilned from the

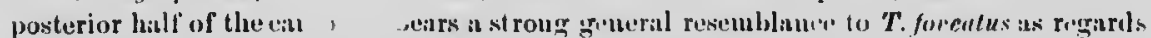
lhe sempture, and also in tho abseuce of the seveath and eighth neurals, anemupaniod by a similar curtailnent of the sixth neural.

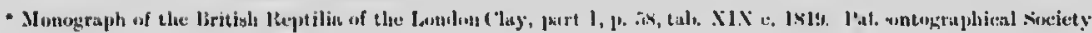


The strong development of the seventh costals, found in the Red leer rive- a resulting in a reduction of the eighth pair of costals, is probably au irregularity of : of no specilic in portance.

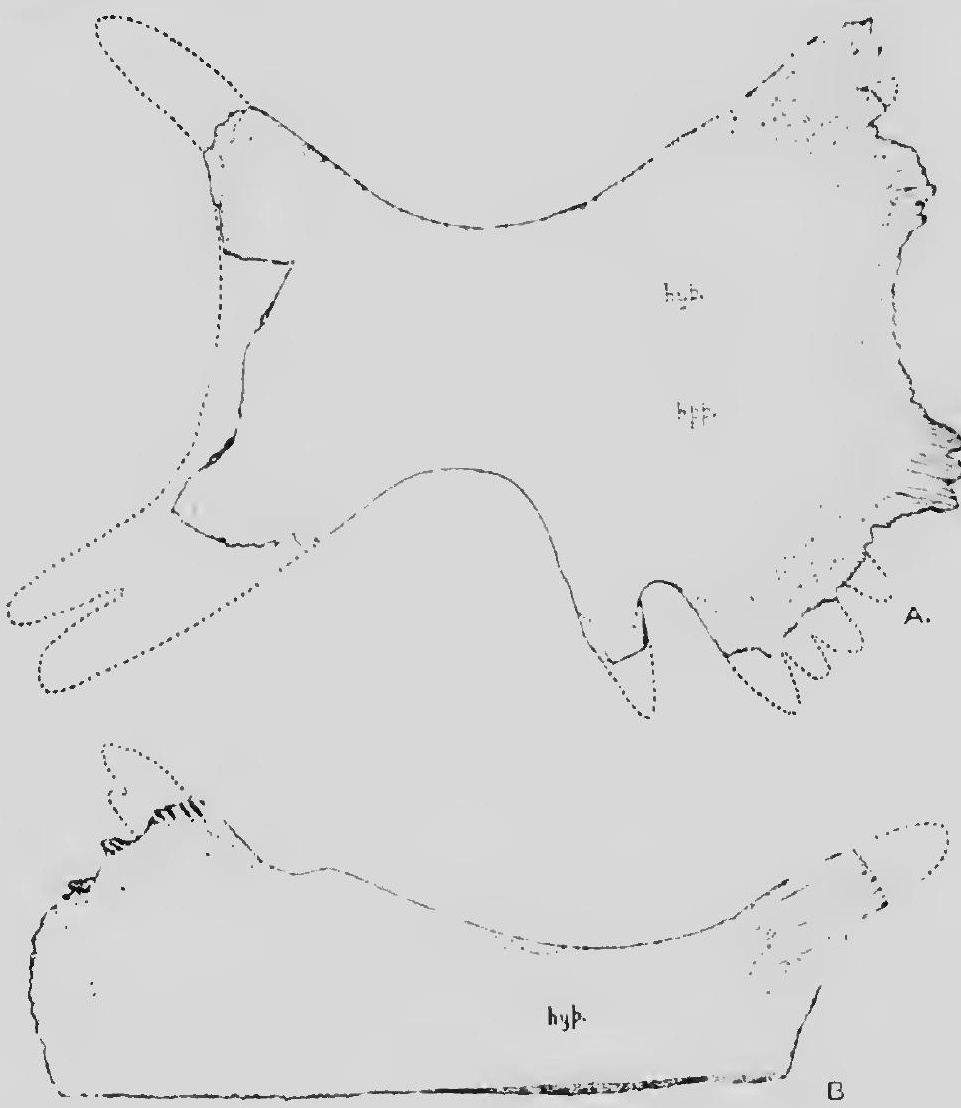

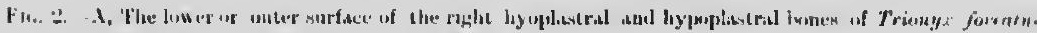

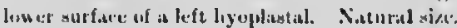

Trionyt vacine, Copre

Plate I, figs. 3 and 4.

Triung.r vngun, Cupe. 1sit. liull, U. S. (ieol. Surv. Terrs, No. 2, p. 27 ; and $1875, V_{4}$. of Cretacous Formations of the West, p. $96, \mathrm{pl}$. vi, tigs. 13 and 14.

Triony, ragan, lambe. 1902. (ieol. Nurrey of Canar, summary kejort for 1901, p. iii nnd is. 
broudest at the sides of the earrupin and uarrowest in front, extends along the whole of the peripheral edge.

A. -egards a divided first neural in spunes of this genus, it is interesting to note that lydekker, in desuribing $T$. sititensis, from the Miorene of Malta, iu 18!11 (Quarterly Journal ef the (ieological Nociety, rol. :svr, p. :7, fig. 1), mentions the owcurrence in the Mincene species of a divided tirst netural, and remarks (p. 37) that "all the fosil speciess hitherto deseriled, of which the entir, ara!nace is kuown, agree witl the normal typo in baving but a wingle long nenral butween tho first pair of eostuls."

\section{Nenaurements.}

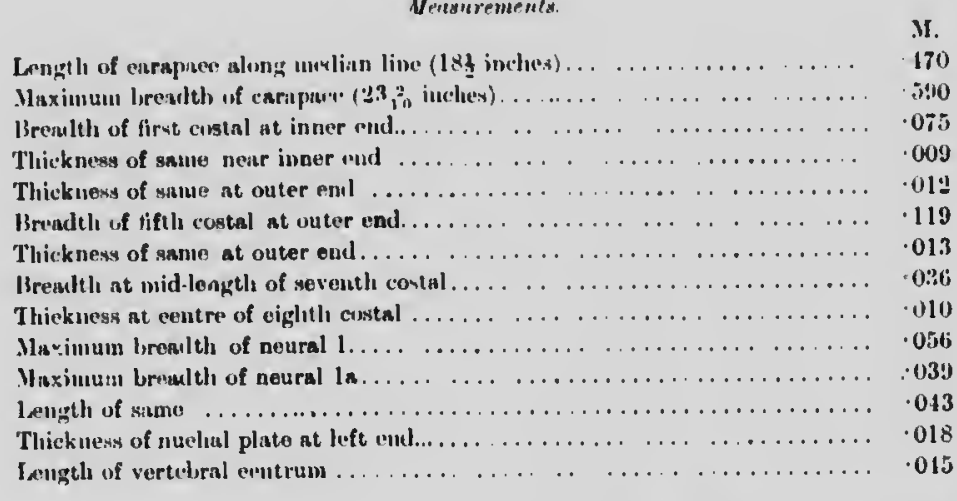

B.lly lives series, lied Deer liver, 18!17, $18 ! 18$ and 1901 ; hesides the carapace above desizibed, separate costals and neturals, and parts of the endoskeleton.

Also in 18s0, l'rofinnor John Mac(nun, neurals and fragrnents of 'osta!s, from Mackuy

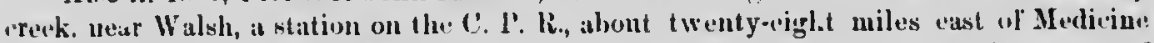

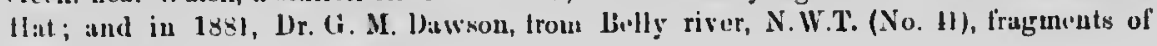
costal bones.

\section{ADre'tul.}

Anoces, Cope.

A Docus (?) tiseolatis, Cope,

Adocus (?) linealatus, Cope. 1875. Report U. S. Geol. Survey Term, vol. ii. Vertehrata of Cretaceous Forumtions of th. Wist, p. 9?, pl. vi, figs. 11 and 12.

This specios, readily recognized by its neat and characteristic sculpture, is repre. sented by two well preserved tragments, one, part of the right hyoplastral, the other, from the margin of the carapace in adrase of the right arillary noteh. The sculptare has the "tppearance of that of Adocus vuriolosus, in miniature, with the roughness worn dowu.

belly River series, led Decr river, 1901. 


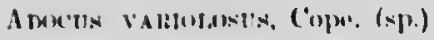

Plato 11, figs. 1, :2 and :3.

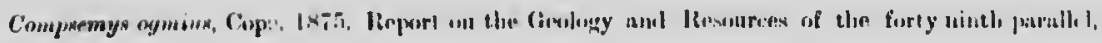
sipentix 13.

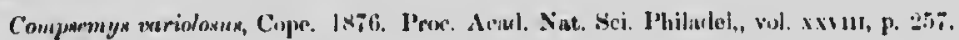

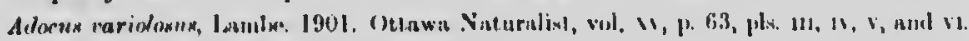

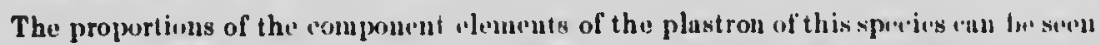
by roferring to figures 4 and 5 , where restored outlines are given, bitsed nn two fragmente of the same shell, which are represented in the figure by the shated I - rioms. The sutures hetwon the bones are shown by the sinuous lines and the boundarie's af" the shields hy the heavy ones. Th" dotted liues represent the supposed shape of the ruel

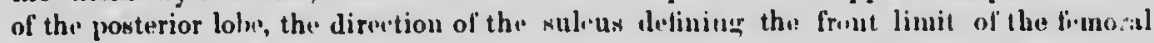
shields, und the position of the sule his ihat probibly eross el the xiphiplastrals, whilst the exteut of the hypoplustrals is conjetetural.

aboven

lackay

dieius: uts of

rats of

repre. $\mathrm{r}$, from has the dowu.

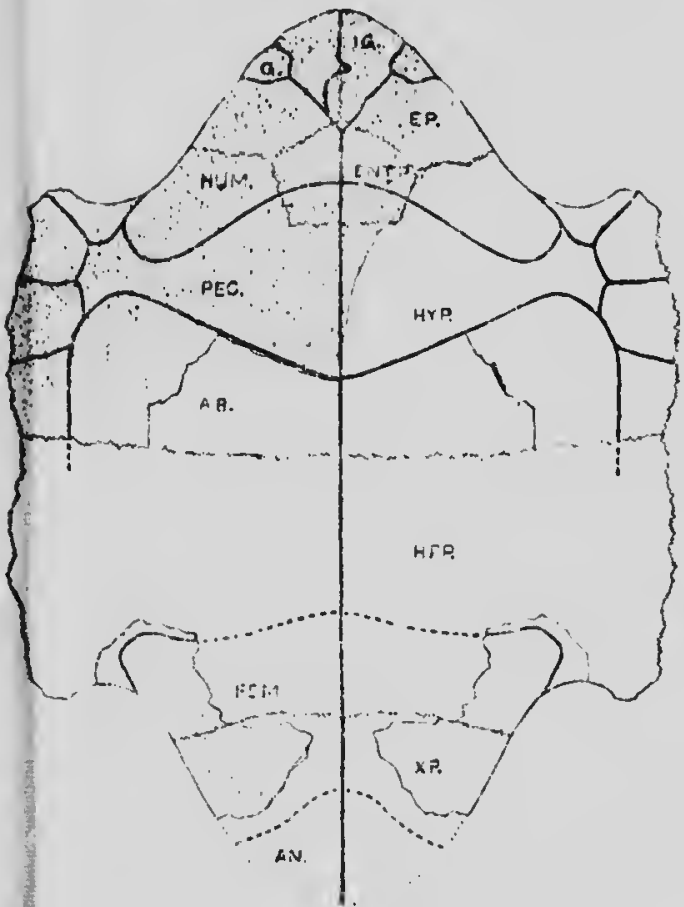

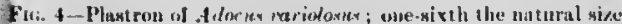

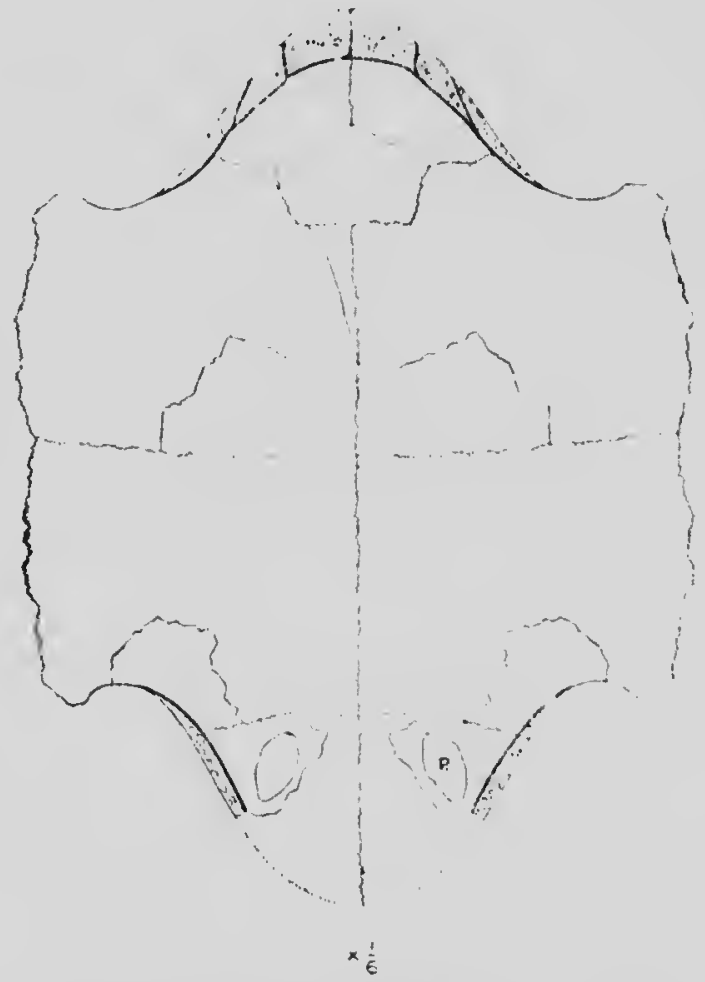

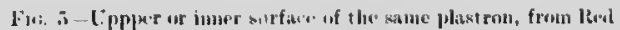
Ihene' river, Allurtel.

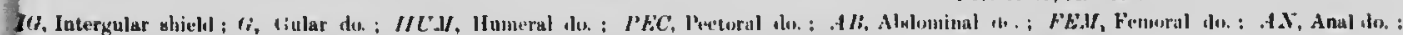

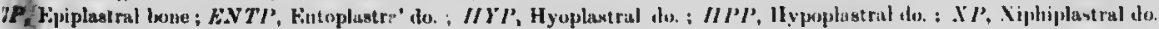




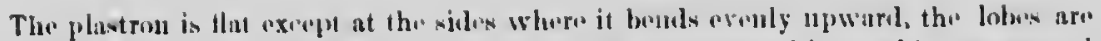

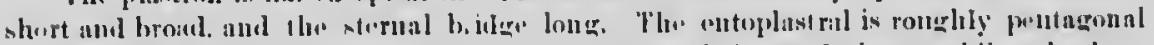

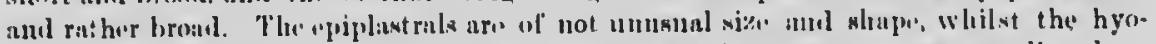

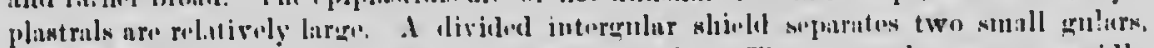
luhind whith aro woll developmel numeral shiolds. The puetorals narrow rapidly

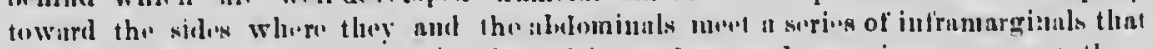

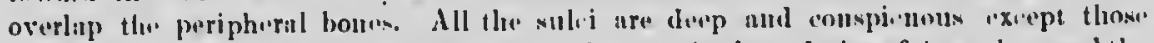

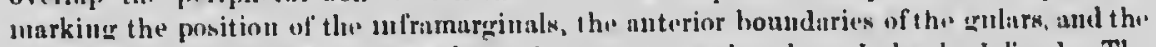
division of the interenlar. These linter, however, are sharply and elearly dielind. The suti:aral line between the lypop!astrals and the xiphiplastrals is showa in the smaller of the two lirierments.

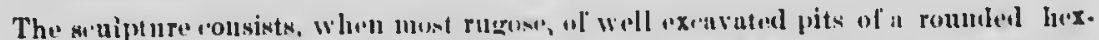

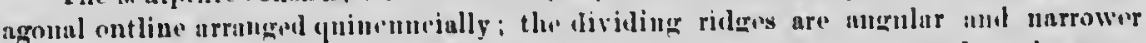

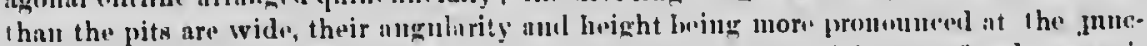

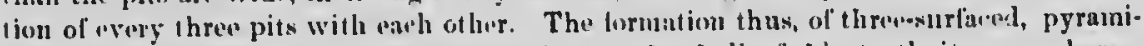
lal projections between tho exivations, grives to the shell of this turtle its very chirac.

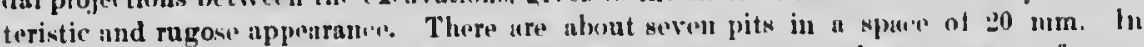

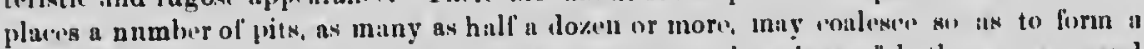

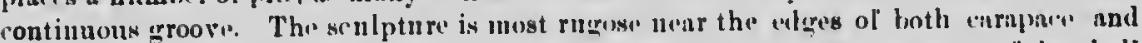

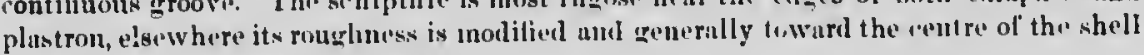
the wurlace is comparatively wmoth

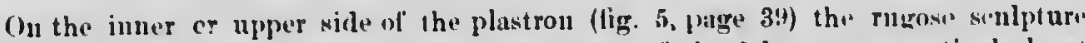

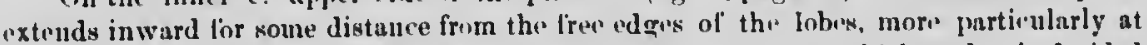
the extreme anterior end, where sloo the bone is vory unuh thick ned A dirided thickening also oceurs in the axillary rewion. The oval outlines on the xiphiplastruls $(l$ '. tig. i) show the position of smooth. slightly raised, llat surfares that are appiareutly lin"'ts for the articulation of the pubic bolles.

Iarge fragments of the carapare show that the costals are thill and ari mited to the

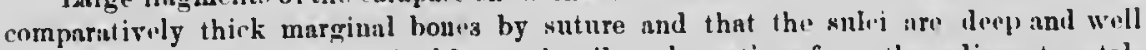
dofined. In some of the marginal bones the rib-prolongations from the adjuent costals are presirred. The rih-heads of the enstals aro apparently will divelopenl.

In 1901, the anterior half of a plastron (fier. A, pige 41 ), with the liront border of the carapane intact, was obtained below the mouth oi lierry ereek. This spevimell, rep " sontiug an indivadual, with a plistrou about $940 \mathrm{mun}$. in length, grive the relr ive position of the plastron to thr carapis'e anteriorly and also shows an eulitrgement of the right pectoral shield to the left of the unedian line of the plastron resniting in a dociled lininution in the size of the left purctoral shirhl.

Additional material ineludes two or three nemral bollos, solne of the bouns ol the

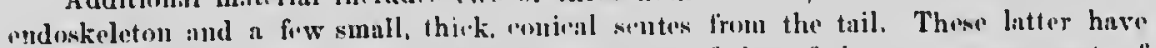

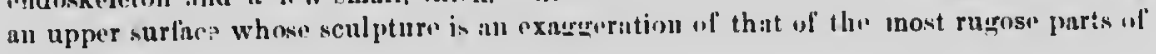
the sholl.

The types of Compsemys ogmius. Cop", from th" "lort Union group" of Milk river, consistiner of two small, poorly presersod fragments of costal bones, show solpture maskiness so similar to those charmeteristie of $A$. veriolesws, that the writor is of tho opinion 


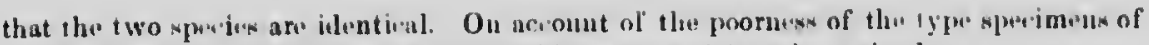

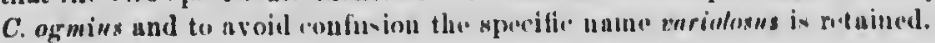

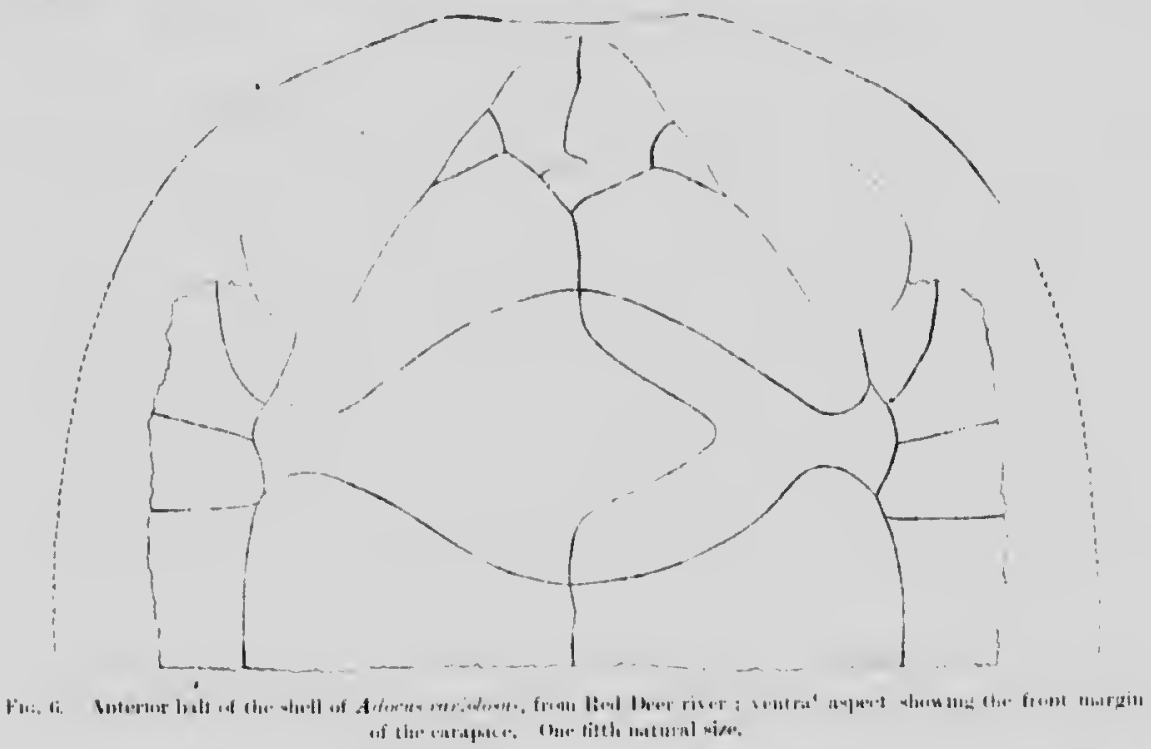

Tho foregoing "laranters indiente a ('loelonian that cannot low rotuined in the senus Compsemys, which is rlosily allial to Plourosfernen aud possuseses a mesoplantral relement. The prese'de' of two small grular shields separated by a divided* or double intergular

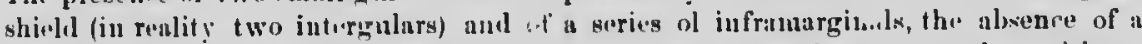
mesoplastral and ol a sutural nuion of the pulvis with the plastron, toguther with an abbreviation of the lobes and a decieled lenethening of the sternal bridge are characters that suggest swih rlose aflinities to the u'nus Allorus of Copt", that this species has be+n refirred to thint genns.

\section{Mensurement}

II.

Fistimaterl lengtls of plastron ( $2:-1$ inclies)

..... 70

Jangth nloug medisn line front anteriur ent in puwtoriur lourter of pectoral shivll. ...

$$
\text { ... . . . . . }
$$

of plastron).

lirealth from melian lian to hateral suturn ( - lasli of brewlth of platerom).

$\begin{array}{llllllll}\text { Length of entoplastral } \ldots & \ldots & \ldots & \ldots & \ldots & \ldots & \ldots & \ldots\end{array}$

Thickness millwany hetween gralisrs. $\quad \ldots \ldots \ldots \ldots \ldots$. . . . . . . . . .

Thickness at centre of gular whic.lds..

Theknegs on meelian line nt posterior loorder of pectural whiehl... . . .

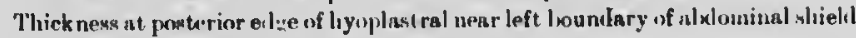

Thicknesy in axillary rugion uear laterial suture........ . . . . . .

Thick ness mic! way between entiplastral anil the axillary notch. . . . . . .
$.2 ! 15$

.280

.0 .5

$1 \div 3$

.035

.0 .33

.013

.007

- 0332

$\cdot 0.25$

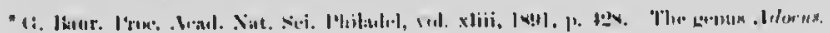

6, 


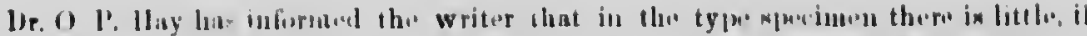

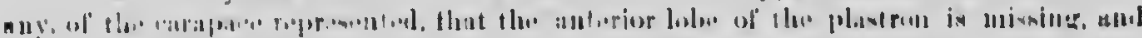

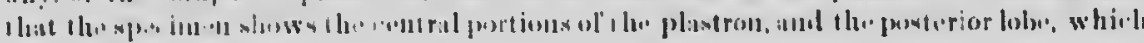
lattor is linotlly roumblat.

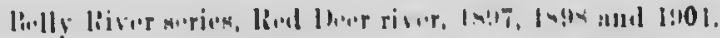

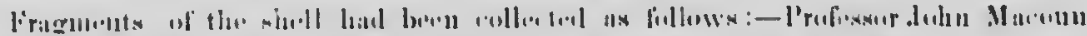

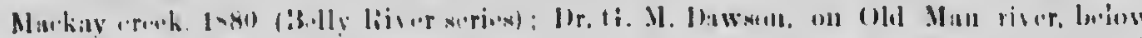

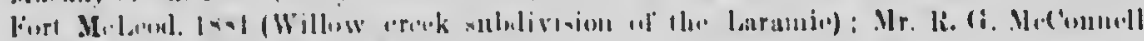

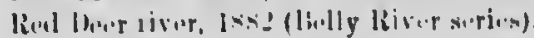

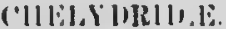

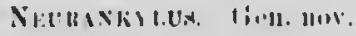

Nitelixh)

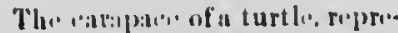

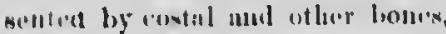
whow in lier. T, is romirkalilu for "rertain pereuliaritios of strutture.

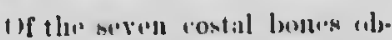
tainel, from the midlle and fust an

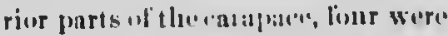
foumd as slowne, unitid to a lareqt nouril anul an moraperal bon". The other three instials, vig il. thiral pair and the right lonrth of with the postoriur astals lua unt in plane. The lift h patir ol costalis was missiner. Th" suldi indionting th, junction of the rostal shichls seren to be normal in their pusition on the thi, bith and 8th rostal loones. What

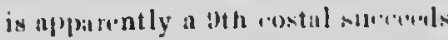

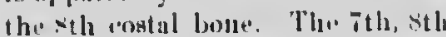
aud at hairs ol"rostals do not rear.h

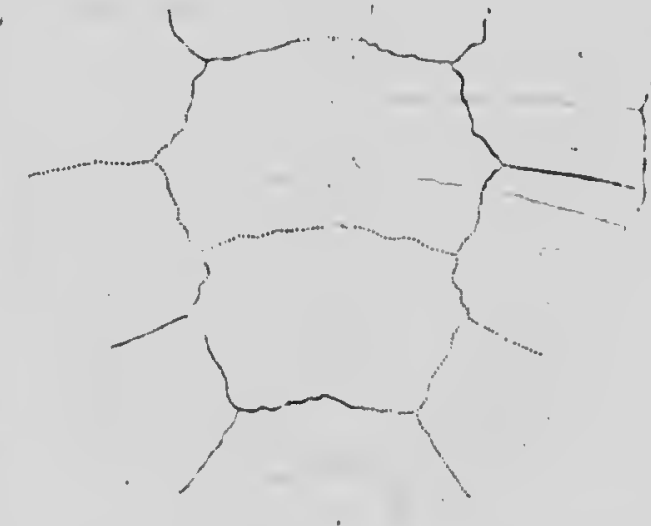

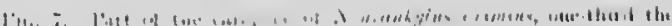

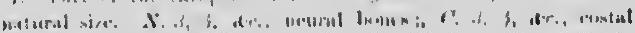

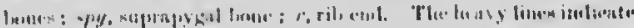

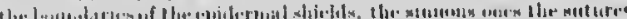

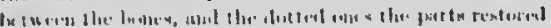

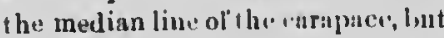

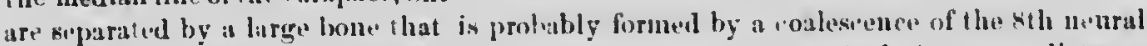
with a suprupyeal. This enlargeal sth venral is suturally uniteol, for some distanea with the vertebral "ads of the ith rostal homes, for the whole of their breadth to the

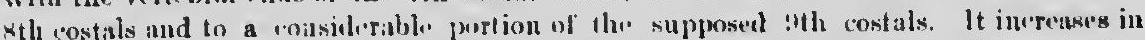

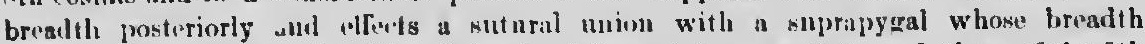
greatly "xemuls its length. Th" rib-heids of the "ontals ure well lormed, those of the 9th rostals buing as fully disuloperl as the others. No maryiual bones wore found with the remains of the curapue. Anterior to the point "a" ou the outer edge of" thi" 9th costal, vacuitios sieen to his" ne'urred betwenll the costals and the margiuals, judgiug

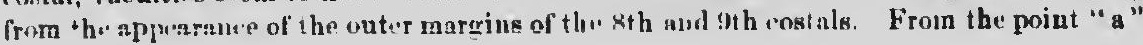


limlin, if jux, alla! $\therefore$ whivls

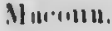
r, lweliow

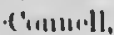

ai1. Iturit the , (ro., risulisl

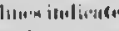
w thr muthitea arol.

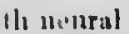
distince th to the arentisis in - breadth of the : ith with the the 9 th , judging ooint " a"

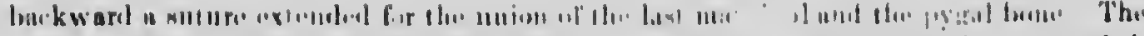

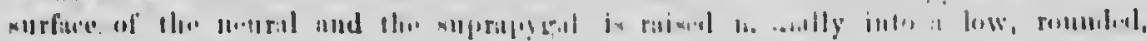
lolluitudiual ridgu.

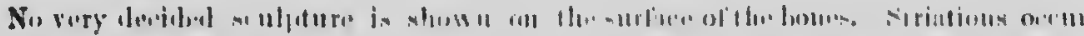

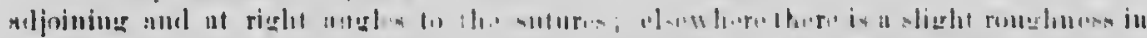

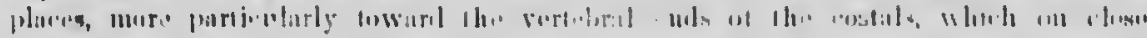

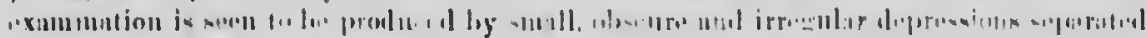

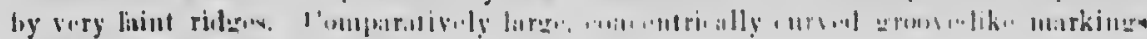

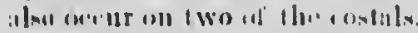

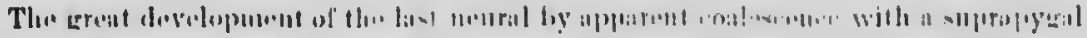

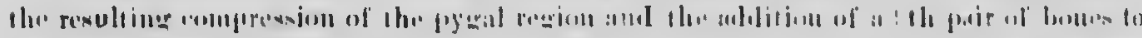

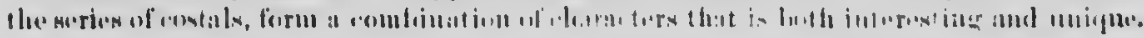

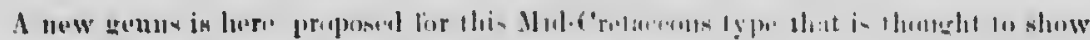

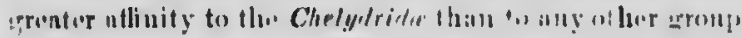

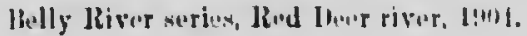

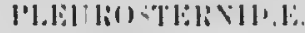 \\ litrise, lublu. \\ Hïive H.T. Hr.H. Hay.}

Barmu hefritari, Ilay 190)1. Inmals

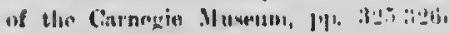

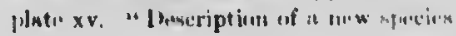

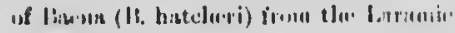
lnols of Wyominge."

This mparion is represindulal

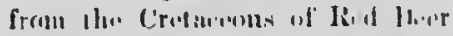
river hy a sperimell, lieg, $\$$, il whith the whole of the plastrou is probersel with the allerior hat l'a!

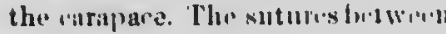

- bolles are well dedimel and the :

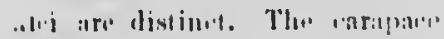
ham anflierol slierhtly from disortion, lum the platirom is achurally

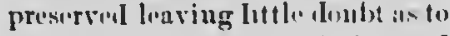
the squatic ilontity af the lind Dear river turth with tha Wyomille 15 pe.

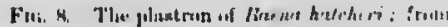

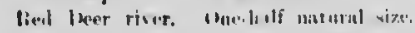

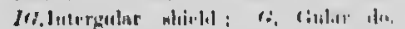

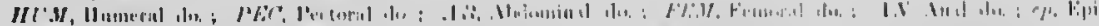

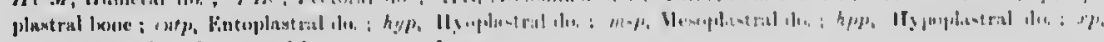

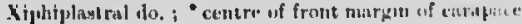




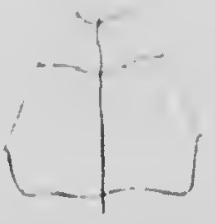

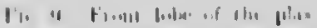

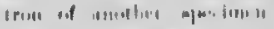

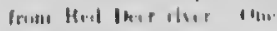

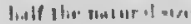

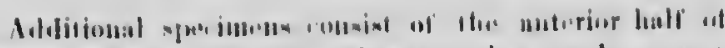

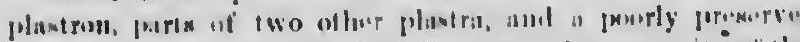

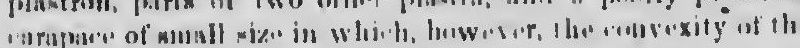
hult of the shell is woll whw

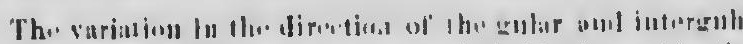

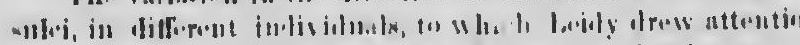

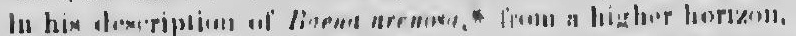

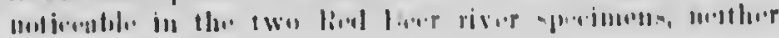
which ogree wxin tly with the ty po.

Holly Risur arian, lind Dine river, 1!101.

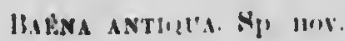

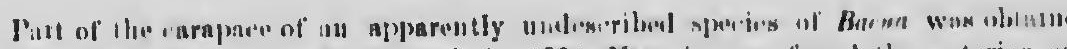

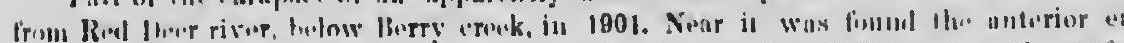

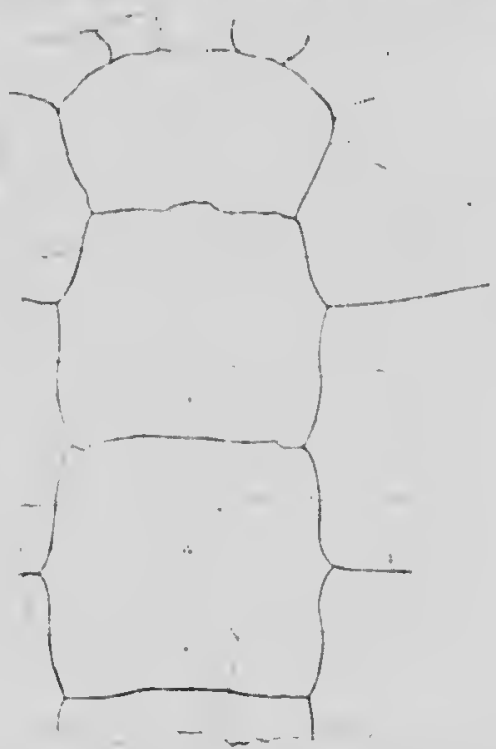

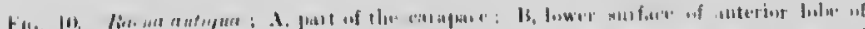

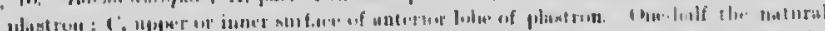

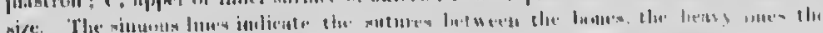

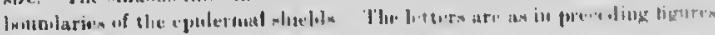
inclividual. of a plastron that, fmlginge from the surfu

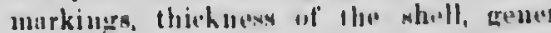

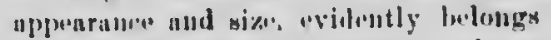

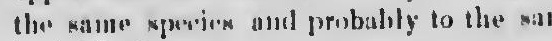

What is presersec of the carapt

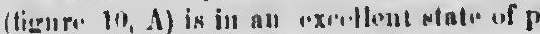

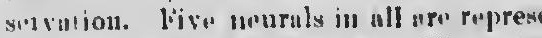
tol with live pairs of rostals. The sutu ar. silluous und fin. lut eall be traced w enso". The sulei very distin.t.

The neurisls rathir irnigul:ır shopi" and of n'a "qual size. Thi.c. als purtuke of same irrecrularit? outliue. Th, ov surlia." is alu smnoth, the 0 murvenuses bo due to a fow $\mathrm{kt}$ tions and dipgrus routrhenind $m$

inges irratically disposid. Striations also oceur at right anglis to the sutures, forming

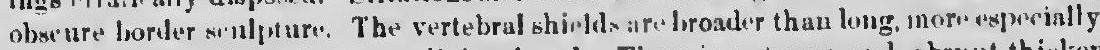
first one. The rib-lunds are well dureloped. Thore is a strong und abrupt thicken

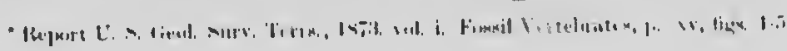


liulf ol forioxicriont xity ul thin

infırrutur w nttoution horinom, in in.lther of

ins oblationed nterior cul thes nurfare . 11, gesucral lo.louge to to the s:tin.

1" carapace alatio of priitriprenellTho: sutures tracel with Tho sulei uro stin.t.

an neuralsare irrigular in and of utarly ixe. Thi insttuke of the rempularity of Thi' outir is almost , the only all'sk being a fow striand dipuressted. ned marks, lorming an ("sperially the ot thickening

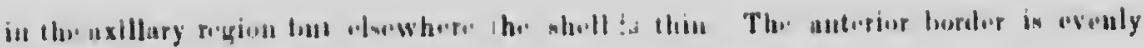
ruindinl.

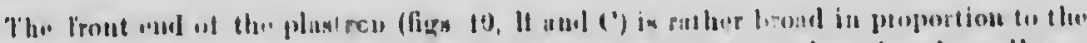

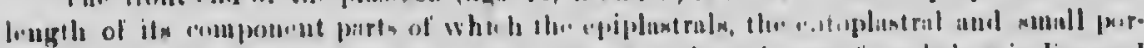

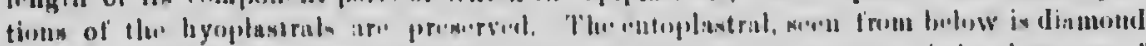

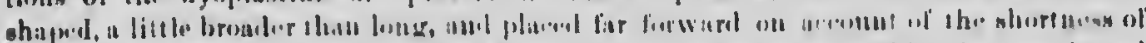

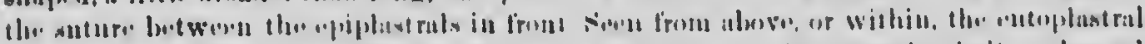

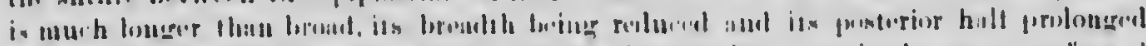

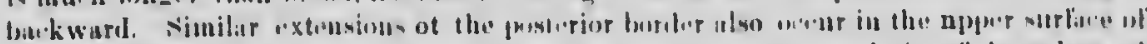

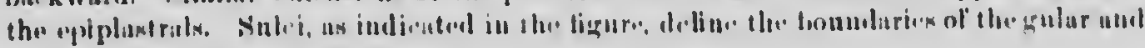
ititrerular whiolils.

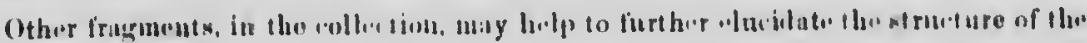
shell of this mperiew.

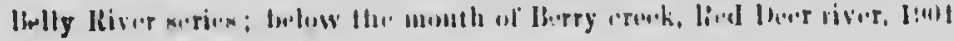

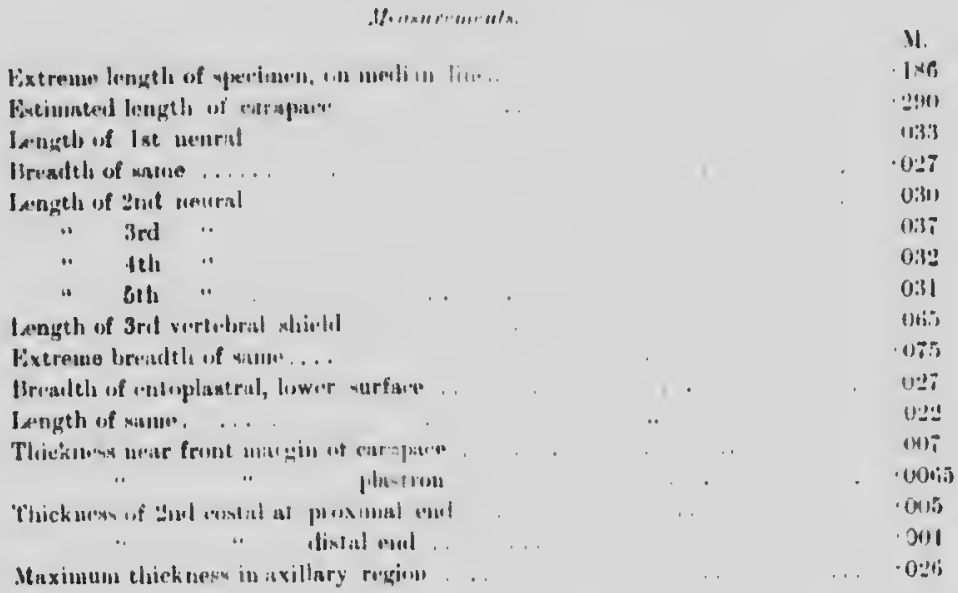

lanlly River series, Red leerer river, lonl.

\section{RHF SCHU 'HPHALI}

\section{CIIA.MUSONALIIIIIE}

Cimamponative, Copm.

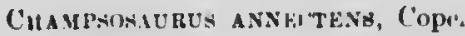

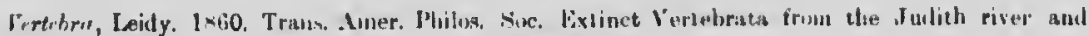

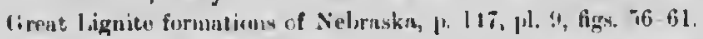

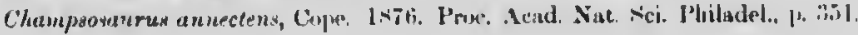




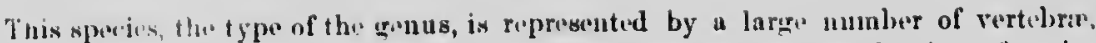
none of which wor. findel together in their proper relative positions, but in $n$ lew in. stances, a wumber, colla'ted within limited areas, may represent incounplete series.

The vertebre consist of cervicals, dorsals, caudals und some from the sicral region The anterior dorsuls are kinled halow, in the dirsal series the angularity grives wny In a rounderl lower surface, the sacrals are depressed and the eatdals, early in their serios, herome laterally compressed. The posterior. infirior ends of the rendal centra presenl finets for ehevron bones; in ont anterior andal. in particular, they are conspicuous with a prononnced eulargement of the e'ntrum in their vicinity. In most of the rlorsal verti-

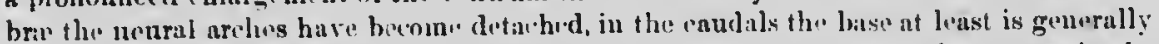
intat. The zygupophyses are well developed. Th" articular lates of the centra in the caudals are slightly concuve, those of the dorsals are plaus. There is " considerablu variation in the size of the rurtehrin.

It is altogether probable that more than one speries is represented.

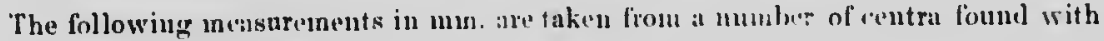
others within a linitıd urea:-

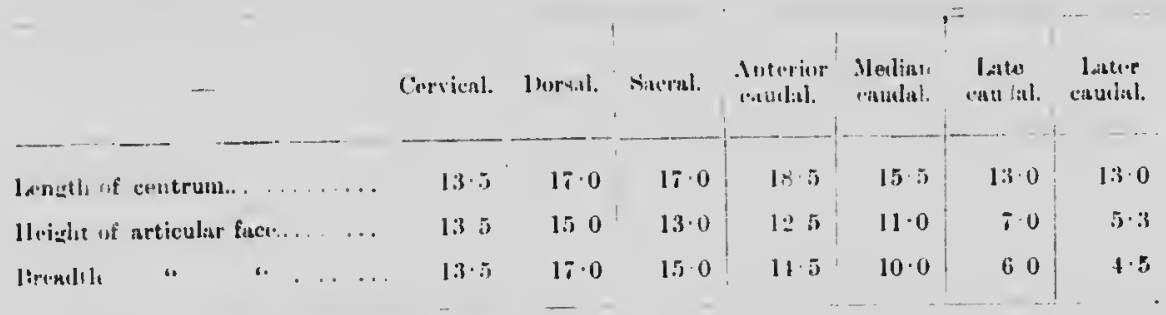

A large dorsal from Markay ireck has the followiug dimensions:- leurth of "entrum, $270 \mathrm{~min}$., height of articular face, $220 \mathrm{~mm}$., breadih of articular face, $2 \% 0 \mathrm{~mm}$.

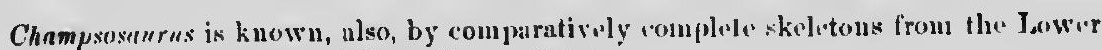
Eo'eno of liheims, lirance, and Erquelinnes, litlginm.

Belly Hiver series, liul Deer rivir, $18: 17,18: 18$ and $1: 101$.

Vertehre were collected at Manky areak,near Walsh stution wit the line of the ('. I'. R., in 1850, hy Professur John Murouu; on li.lly river, N. W. T. (Nos 40 ind 41 ), iu

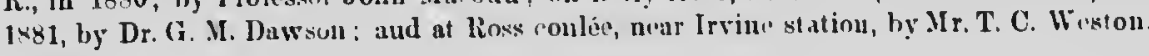
in 1884 . 
certchrat few in. les.

l region way to il ir sericy, I prose'ul ous with al vertr.generully $\mathrm{ra}$ in th" siderablo.

Ind with

I atte.

caulisl.
SUUA.I.IY.

Troül)us, Laid!̣.

Troobun Folimosus, loily

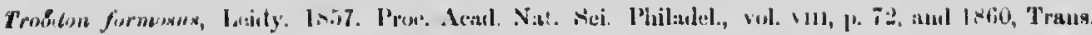
Amer. Phitos. Soc. lixtinct Vertoinat: from the J unith river and dirent l,ignite furmations of Neloruska, p. 147, pl. 9, ligs. 53,54 und 55.

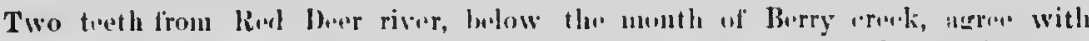

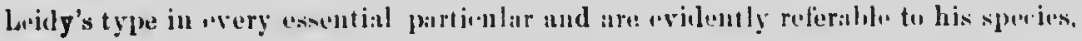

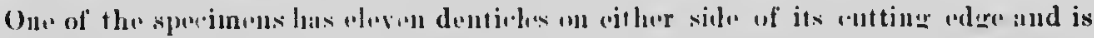

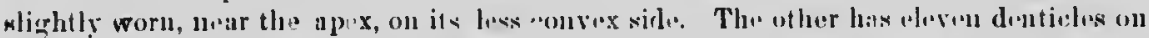

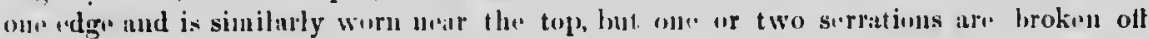

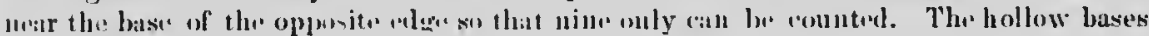
of both towth are ingerliat. luluw.

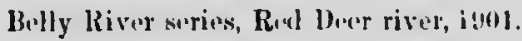

This sperien is plated provisionstly with the: Laterliliu.

\section{CRUCUIMLIA.}

rerocontits IIUMHits, laily.

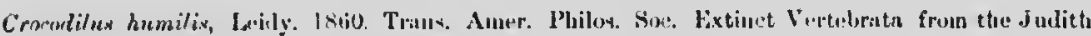

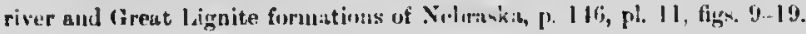

Treth of this spories ar: finul abmulantly in the ronks of the lbolly River sarios.

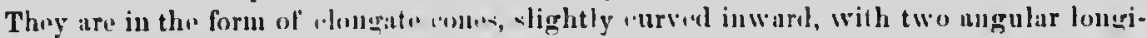
tulinal ridges dotining the sliphtly Hattened inner side. They are gemerally quitu.

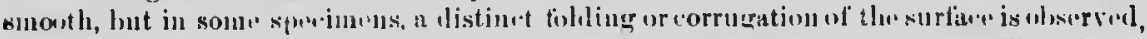

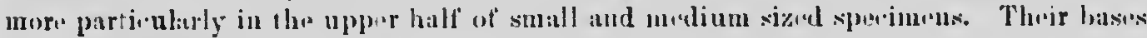
are slightly excillated. Thu apions anderally shuw signs of war.

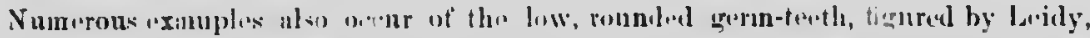

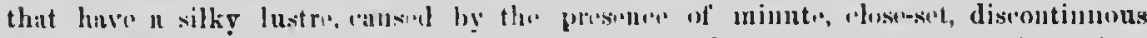

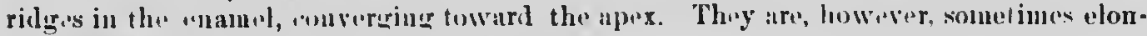

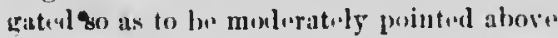

Bully liver suries, Rud Done river, $1 \times 97,18 ! 98$ and $1 ! 101$.

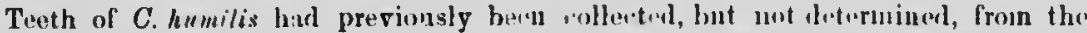

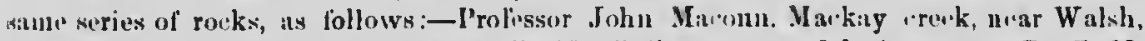

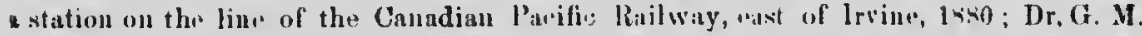

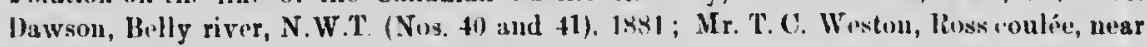
Irvino, 1884, and Irvine coulé, also near Irvine, 1888. 


\section{Buttogaurun perhugosoz, Cope.}

Bottonaurus perruyosiz, (ope. 1875. 12uport U.S. Geol. Survey Terrs, vol. 11. Vertebrata of Cratit cenus Formations of the West, p. 68, pl. vi, figs. 5-4.

A left mandibular ramus, from which the posterior euds of the dentary and splenial bones and the artienlar and coronoid elements are missing.

The snpra-angular shows, ou its iuner posterior surface, the facet for the articular bone, and also in its lower border the posterior end of the external mindibnlar foramen. The lower margin of the interual mandibular loranen is sen in the auterior half of the angnlar. The external snrface of the deutary shows small, deep pits directed forwarl and inward, from each of which a shallow groove passes backward for a short distance; the pits are arranged in somewhat obseure longitudinal rows. The lower outer surface of the augular is rugose, troin the presence of deep grooves running in a longitndinal direction. This outer semlptnre chaugos, in the supra-angular, into an irregular and bold network of ridges 'n'losing deep, suuken area. Altogether the surface markings are as shown by Cope iu his figures.

There are sixteren sockets for teeth, the secoud, third and fourth of which, counting from the front, still retain a hollow root. The symphysis is will shown. The front end of the splenial euters into the formation of uearly one-fourth of the symphysis. A foramen passes throngh the splenial immediately behind the symphyseal snrface.

The species is still further represented, in the collections, ly the ociput of nother individual, obtained in 1901, and requiring further study. Numerons vertebre und bony seutes of Crocodilia have also been obtained, some of which will probably be found to belong to this species

\section{Measurements.}

Frtimated length of ranus ....

....... .

Heiglat is line with posterior napriu of extrernal uumblibular f rum $11 \ldots \ldots .053$

Width of Inwer border where the last umeasurement was toiken . . . . . . . 016

Height of symphysis.......... . . . ... . . . . . ... . 018

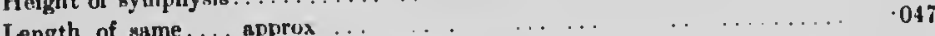

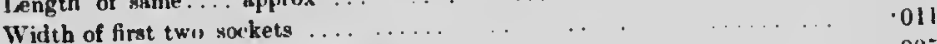

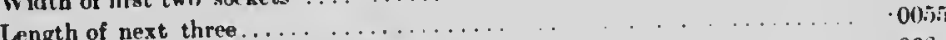

length of tentli and eleventh rocket, ......

Iength of fifternth socket ... . . . . . . . . . . . . . . . . .

Jistanue between onter edges of quidrutes, punteriurly . . . . . . . . .

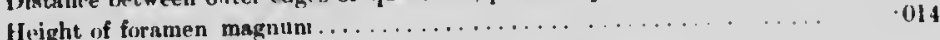

Helly River sories, Red Dier river, 1897, 1898 and 1901. 


\section{IM.NOSAURIA.}

DRY PTOSAULIHA.

1):INopus, Luidy.

DEINODON ILRRIDU, Leidy

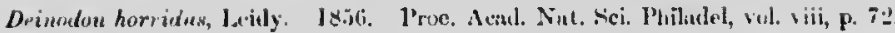

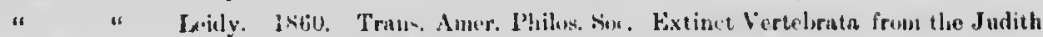
liver and Great Lignite formatious oỉ Niblonska, p. 113, pl. 9.

A number ol megalosanroid teetli, the largest ol which measnres $90 \mathrm{~mm}$. c io convex curve, are rulierred to this speries. The general shape of the toeth and wo serrations agrec closely with some of Leidy's figured types, viz., those slown in figures 21 to 32 of plate 9 ol the abore quoted work.

1 danges (incluting torminal onts) and a motatarsal with fragments of orobably also reforable to this speries.

Bolly River series, Red Deer rivor, 1897, 1848, 1!n!.

That Inidy was correct, in supposing that the teeth to which he gave the name Deinolon, bulongenl to a single aninal, is most probshlı, in view ol our present knowlinge of the teeth of cirnivorous dinositurs. The toeth of : inalon were evidently

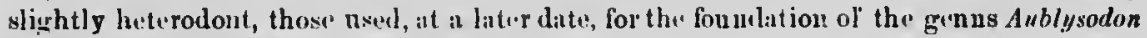
being prolsibly the anterior teeth of Deinoslon.

Dr. O.P. Ilay has reerntly pointed out (Ameriean (ieologist, 1899, vol. xxir, p. 346) that the nume Detnofon, as originally spelt, is ant prow'upierl. This name, as a generic term is here retained and the nimn. Anblysodom is reugurded as a nomen nudum.

\section{DETNODON FXMANATUN, ("opt. (sp.)}

Plate $\mathrm{XV}$, figs. 11 and 12.

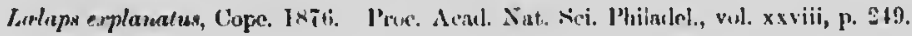

A sull tooth agreceing with Cope's deseription. The posterior roncave edge is minutely clentirulated throughont its longth. The convex rodge, in its apical half, is still more minutely sirrate. (1ne sirle is almest llat, the other gently couver.

\section{Mectsirentients.}

Length frous entre of base to apex $\ldots \ldots \ldots \ldots \ldots \ldots \ldots \ldots \ldots \ldots$. $01 \pm \ldots \ldots$

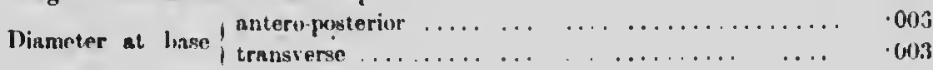


Belly River series, Red Dcer river, 1901.

Many small teeth of the Megalosauroid type have been collected from these hed Probably somi of them will be found to belong to other speries of this genus deseribe by Copr.

\section{ORNITHOMIMIDE.}

\section{Ornitilomimud, Marsh}

ORNITHOMIMUN altus. Sp. nov.

Plates XIIl and XIV, and plate XV, figs. 1-8.

A hitherto undescribed species of dinosaur, belonging to the Ornithumimila ar relierable to the genus Ornithomimus of Mursh, is represented by a complete right hit limb (including the foot), the phalanges of the leit foot in place, an pubic bone, and ischium, of one individual.

With these, as probably belonging to the same speries, are included a posteri dorsal vertebra, eaudul vertebrix of reinarkable form, phalunges of the manus and number of teeth of puruliar shape.

The firmur, tibia, metatarkals and phalanges of the pes, exeept the terminal on are hollow.

The femur is shorter than the tibia. The astragalus is closely applied to but de not coalesce with the distal end of the tibia; it has a well developed ascending proc apposed to the front face of the tibia. The fibnla is slender and the tibia has a promine cuemial erest. The calcanenm and the tarsal bones were found iu place. Metatarsal I as in Ornuthomimus velox,* Marsh, fits closely against metatarsals II and IV, and is, a sh distance above its distal end, triangular in sertion with its flat fate foremost. It becon attenuated above and passes behind the other two metatarsals. Metatarsal V, rep a.nted by a short, laterally compressed, slightly curved bone, lies close to the proxin end of metatarsal IV.

The phalangeal formula is $3,4,5$; digit 111 is the longest and digits II and IV oi about equal length. The terninal phalanges are sharply pointed in frout, rat ktruight, llatteued below and deeply grooved on the sides. The grooves are earr forward to the extreme point and indieate the preseuce, during life, of a long but sharply curved or pointed claw. The other phalanges have derp pits, one on earh of their distal extremities. The shape of the terminal phalunges anggests a foot, suituble for grasping but adapted rather for speed in running, an idea carried out by slenderness and lightness of all the bones of the leg.

The posterior dorsal vertebra, plate XIV, fig. 1, is decidedly amphiccelous, the concar in the anterior face of the centrum being more marked than in the posterior one. 
these beds. 3 dentribud

nimida and right hind one, and au

a posterior anus and a

rminal ones,

to but does ling process a prominent etatarsal III, ad is, s short It become's sal V, reprethe proximal

I and IV are front, rather 8 are carried ong but not on earh side is a foot, not d out by the or one. The

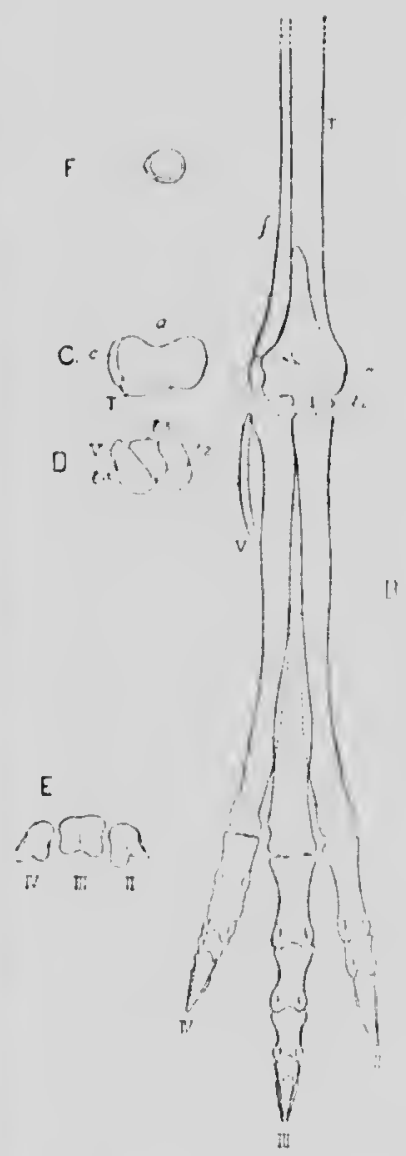

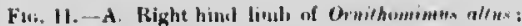
right lateral anpect. $B$, fint of the wane: frust view. C, diatal end of thisia 11, proximal eml of metatamais. F, ilistal enil of salue, F, tranavirese action of tibis. Figures one-sixth the natural size. $I_{n}$, ischium : $\boldsymbol{F}$, tentur ; $\boldsymbol{r}$, pubsis ; $T$, tilin ; $\boldsymbol{F}$, tibula; a. estragalus; $a$, ascending process of antragalus: r, calcancuu ; 1 , taral tone: II V. digita. The inchium and pulbis are inilicuted in the pration, relative to the femur, in which they wre found.
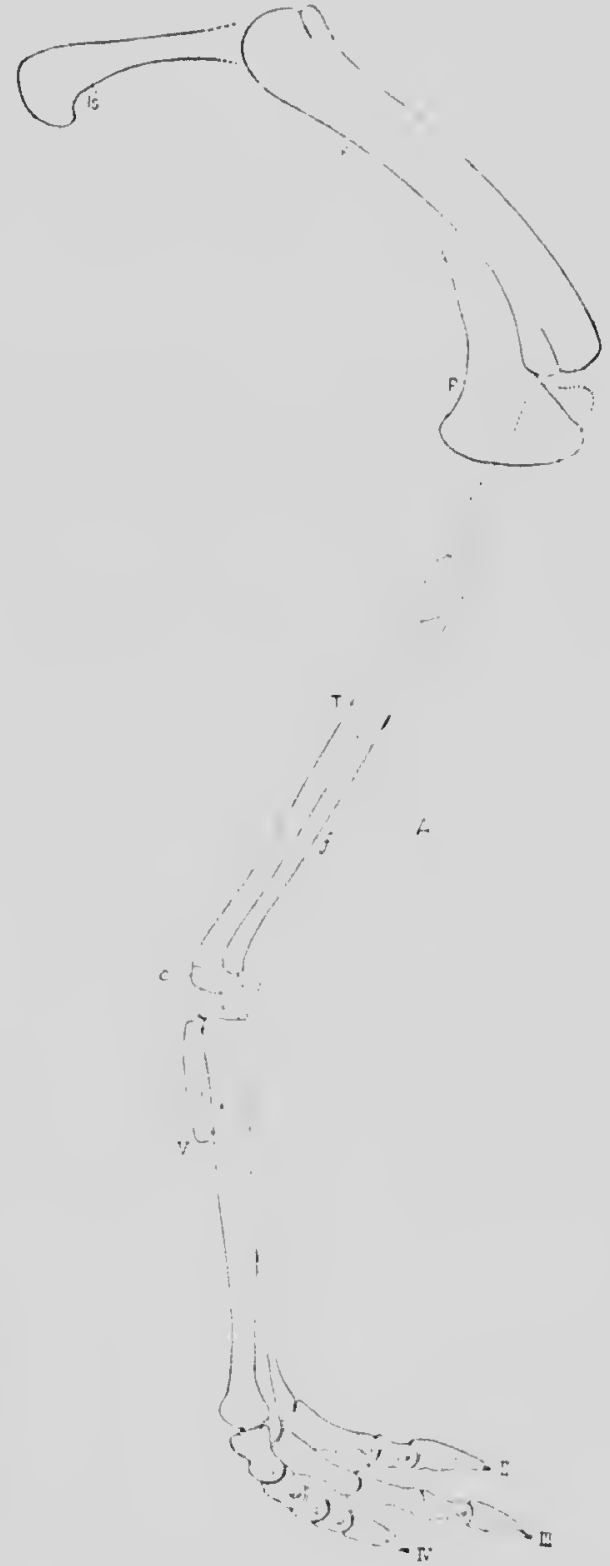
cuntrum is constricted at mid-length so as to have vontave sides and low'r surface, theres being at either end of the latter a brond median groore. The neural arr'h does not reach liar below the top of the entrum. The diapopliyses (imperfect in the specimen) have stout hases, relatively brond in their antero-posterior dianuters. The faces of the preaygapophyses are directed obliquly inward. The neural spine is well developed, short, deep from back to front, shallowly convive un its sides, with rugose, slightly excavated, anterior and posterior surlia'es. The centrum is hollow, its walls dense and about $2 \cdot 5 \mathrm{~mm}$. thick at mid-length, the inuer space extending 10 within abont $6 \mathrm{~mm}$. of either end.

The caudal virtebrie, plate XIV., figrs. 2-5, and plate XV., figs. 1-5, supposed to belong to this species, are remarkable for the suppression ol the nenral spinc and the forward horizontal extension of the prezygnophyses to a distumce in advance of the anterion end of the centrum nearly equal to the length of the centrum itself. The postaygapophyses are represented by a barkwarlly directed, laterally comprissed, unarly horizontal procese that fitted betwecu the prolonged prexygapophysial proeesses of the snceeding vertebra The centrum is long compared with its height, slightly coucare on its sides and lowes sarface, with a strong median groore helow. In different specimens its interior may he moderately hollow or instend a number of varuitios of ruriable sizo may be present Sinall facets, for the atta.hment of the cherron boues, are present at the lower, posterio ends of the eentra; thest" are not recognized at the anterior ends. The neural spine sometimes represented by a narrow, rounded ridue /shown at "w" in the specimer fig:. d on plate $X V$., fig. 2). 'l'he prezygapophysial pro''sses are broadly expanded lacer ally, contracting and thinning gradually anteriorly, their outer edges orerhanging th sidis of the anterior end of the centrmin and extınding lower than the median uppe surface of tho same; their luwer surfaces are slightly striated lougitulinally. Th neral t'anal is small, its ontlet, anteriorly, is wider than high and is roofed over to point above the anterior end of the entrum. These caudal vertebrie indicate a tail o considerable length but their manner of articnlation would scarcely admit of mucl lateral motion.

A number of phalunges of the supposed manus of this species are also hollow bo present a differcue in the shape of the terminal phalanges whilh are curred an laterally compressed with a gruove on earli side extendiue from the apex back $x$ ard an dividing into two branches toward the proximal end. Judring from the size of then phalanges the manus was smaller than the pes, and thir shipe snggests a graspin eapacity; the terminal phalangres were probably encased in shurp, hooked claws givin their possessor the power of traring its proy.

Two bones, probably the distal ('nds of the lirst metatarsal* and the first metacarpe were lound with, the phalanges of the manus above referred to, phalanges of the pes, separate ustragilus and a ealcanemm.

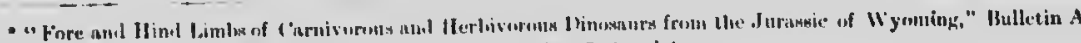

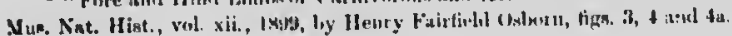


ace, there not ruach pecim(in) ces of the a veloped. $\therefore$ slightly lense and if $\mathrm{mm}$. ol

ploosed to did the fore anterior apophyses al process vertebra. and lower or may be e present. , posterior al spine is spocimell aded lacernging the ian npper ally. The over to a te a tail of of much

hollow but urred and kward alld ge of there a grasping aws giving

metacarpal, $f$ the pes, a

Bulletin Am
Jenaniminents

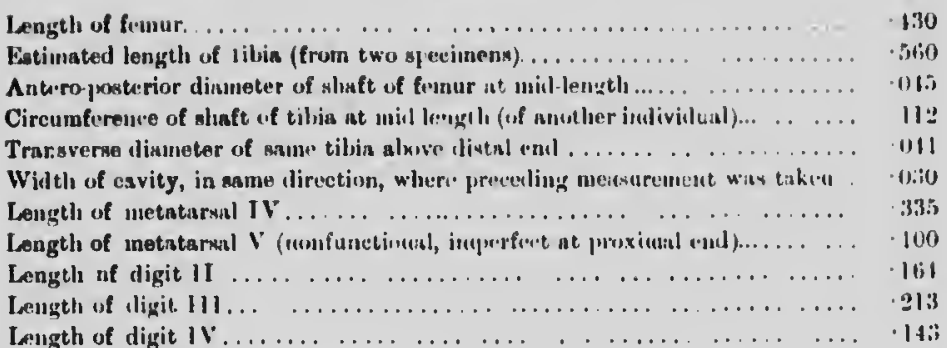

The tooth represented in figs. 12 und 13 of plut. $\mathrm{I} / \mathrm{V}$ is provisionally assoninted with this species and is regarded as being from the anterior portion of the jaw. A similar tooth, figured by Leidy, in his memoir on the Judith river vertebrata (Traus. Aner. Philos. Foc. 1859 ) is referred to in his description of the teeth of Deinulun horrilus as all aberrantly formed specimen. Leidy suspected the tooth to be an illeisor.

In the tooth figured on plate XIV, one only of the posterior keels is denticnlated and that only for a short distance at the centre of its length; the other is smonth. Another specimen is apparently without dentivulations.

A number of teeth of this shape, with others intermediate in lorn between them and the orthodox Megalosauroil tooth, were collectinl in the Red Deer river district. They are referred to the present speries on account of their frequent occurreace with and near the remaius of $O$. allus.

The estimated length of Ornillomimus altus is 22 fiet.

Belly River series, Rud Deer river, 18!17, 1 s:8 ant 1!101. The right himl limb with the phalanges of the left foot, were fonnd in 1901, below Berry creek.

The following remains ol this species besides those alrealy montioned haro beell collected; hy l'rofiessor Johu Ma.onn, in 1s80, on Miwkay ereek, u'ar Walsh on thu lint of the C.P.R. phalanx of pes (Belly Rir.r series); hy Mr. T. C. Weston, in 18.54, at hoss conlex, near Irvine, abont eighteen miles cast of Medivine Ilat, parl of a raulal rertebra, phalanges ol the P's and il phalaux of thi m:anus (Belly River series) ; by Mr. Weston, in 1889, part of a randal vertebra and phalanges of fres, labelled, lied Iteer river, rauge xxi, tp. 32 west of 4 th I'.M. (Eilmonton suris's).

\section{STEGOS URIILE}

Pad foscincus, Leidy.

I'AJ,zoscini'us' costatus, Leidy.

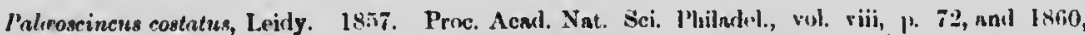
arans. Amer. Philow. Soc. Bxtinct Vertelirata from the Julitl river and (ireat Lignite formations of Nebraskan p. 146, pl. 9, fign, 49-52. 
In the eollections are a few terth that cannot be diatingnished from the one tignre liy Jeidy in the latter of the above two publications. Of thee, an average specimen is the same size as the type and has the same number of serrations. As the crowns of som are worn the exact number of serrations that the tooth hal originally cannot always ancertained. Their sides are smooth. They seem to vary little in form but are proporti nately thicker, near the base of the erown, than the type.

Bully liver suries, Red Deer river below. Berry creek, 1901.

PATARGCINCTE AAPER. Sis. nov.

Plate XVII, lig. 5.

The tooth for which the ubove name is proposed is in the form of a laterally ton presed colle, with a serrate "dg' and ruguse sides. Tho root was evidently cylindrio bnt has Ine'll broken off elese to the hase of the erown.

One side of the crown is more rugosely striated and flatter than the other which devidelly ronrex. The trenchant edgo has eightenn serrations, fifteen only of whith sev $n$ in a side rie'w, as the last three on the right (as ligured) are paired with thror oth of eqnally small size. The groove separating these three prairs is deen and decided. T other end of the tooth is Ilattened in an almost vertival direction; sore the serratic enrve towarl the side of the greater ragosity. The broad apioal denticle is the one th shows the most wear. The base of the crown is evenly rounded below to meet fang.

This touth differs materially from others of the genus descrilwed by Jaidy and Mar The sirrations are more numerous, the sides more conspicuonsly ridiged, whilst the dou row of tenticles at one "ml of the cutting edg", besides b.ing novel, is most interest and instructive, in that it is suggestive of a progressive strp towari the developm of a donble row of tubereles such as is found in tho molars of the Multituberculates.

The speritioname here snggrested has refierence to the rough sides of the crown the tootl.

Mrtesuriments.

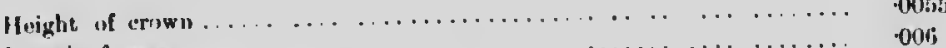

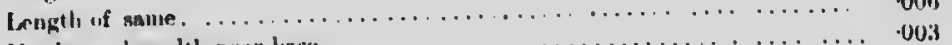

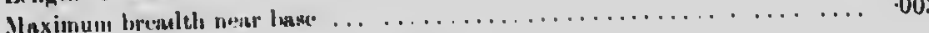

Belly River series, below Berry creek, 1901. 
one tigured wimen is of vns of some alway" be proportio-

terally com- eylindrieal

ur which is of which are throw others eided. Tho a serrations tho one that to meet the

and Marsh. st the clouble interesting devolopunent reulates.

he erown of

\section{NTEREockplialid. Goll. nov.}

STEREochplial,Us TUTUA, Stp. nov.

Plate XI, plat, XII, tigs. $1,2,3,4$ and 5 , and plato X.XI, ligs. 6,7 and $*$.

The specimen of which views from above, from the side mul from haluw are given on plates XI and XII, ropresents part of th" plateprotectod eranium of a herbivorous dinosanr, that is, apparintly, quite distillet from any hitherto desi-ribud.

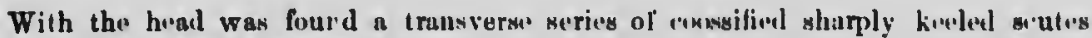
which will bo descrihid farther ou.

The part of the head presirved is st rongly anvex transversoly, but only underatesly so froin frout to buk. ('oossitied plates nover th. whol, of the upper surfare und are contiuund down on the vertical sidis. They aro arranget with a certain amonnt of lilateral symmetry, are quite small at the "entre and toward the baek, but arw larger in front and rery mach mor" so on the sides. They are lor the inost part irrigularly live or six sided, with rather undulatory surfar.s that aro narked by an irrogular, raised, si rin. tural cross-hatching, feebly suggestive of tlı. surfure markings of the platen of Nislosunrus textilis, Marsh. Small vasinlur openings and grooves ure also unuterums on the nurface. The edges of the plates are as a rule angular and sunotimes raixed. liarh plat, has its limit defined by a deeprein'umaribing lurrow, no that althongh they are ronssifind and forn a continuous surface "overiug to th" head, they do not lose their indiriluality. A rounded node, or an incipient kinl is noticed on soine of the plintes.

The removal of sandstome from the lower surface of the specimin revealed thio bones of the palatal region (plate XII, lig. 2). The interpretution of these elemints are as indiented by the letters. The back ends, only, of the palatincs (p.) arc secen, mentiug the pteryguids in a suture indieated at "s." From lere the lattır bonex (pit.) extond binck. ward on either side of interpterygoid varuitios (v.). Th. ridge (ph.) reprexints the presphenoid and basisphenoid : lements; it is bent posteriorly to one sile "I the spreciunen, which has been subjeeted to consilerahlo pressuro from above and is somewhat erished behind.

From this interpretation of th. bones of the pialate it would appear that the part of the armature preserved eovers the upper part of the head mar the union ol the nasals with the frontals. No indication ol the orbits an bu detceterl and it is probuble that they were placed far forward in the h" $2 \mathrm{~d}$.

Part of a rih, having a T-shaped transverse section (Plat, XtI, fig. 5), such as is characteristic of the heavily armourid Stegosnuria, was found sepurately but in the sane locality, and is prorisionally assoviated with $S$. lutus. The finding of such a rib is suffi-

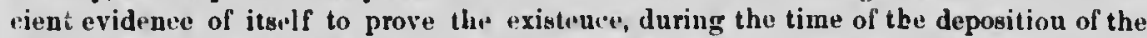
Belly River series, of a large dinosaur having a heavy protective covering of bony plates 
.950

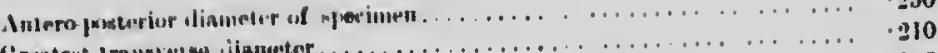

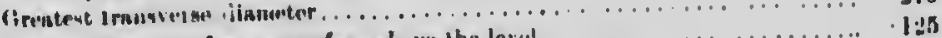

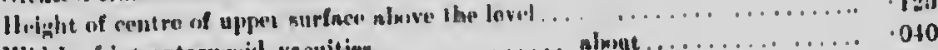

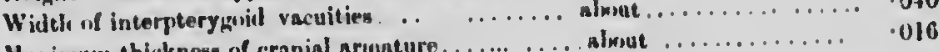

With the head, just deacrilied, were five kinled, bouy seutes or plates that have sin been found to fit together in the furm of an arrh (plate XlI, fige. 3 and 4), whowe sid

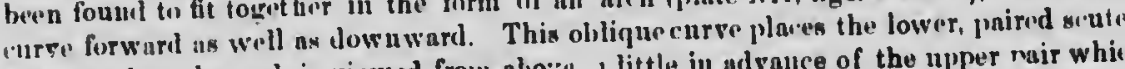
an sec'll whell the ar'h is riewed frou nhore . little in adrance of the upper rair whi is again alightly in advaine of the median plute

The orates rest on and are ossilied to a thickuess of boun that constitutes the inm

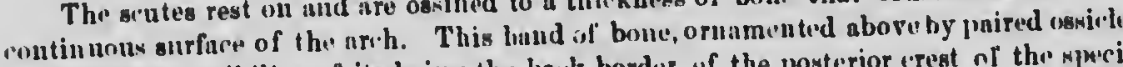

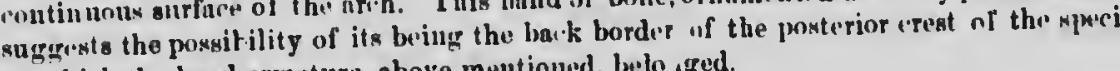
to which the head armature, above mentioned, belo gged.

This suggestion is given credence from the fart that the "oncile edge of the hand bone on which the sentes rest is fructured, whilst the conver alge appears to be intm:

Numbering the ensicles from the right, the junetion between Nos. 1 and 2 was $p$ fort, as were ntso those hetween Nos. 3,4 and 5 , but in the cuse of Now. 2 and 3 the fr tured edgew did uot fit with sullicient exantnews to remove all doubt as to their hei plaend sido hy side, although the continuity and symmetry of the curve of the une surface seemed complete. It is possible that one or two se utes are missing from het we Vos. "2 aud 3, especially as fragineuts ol sinnilarly shaped scutes wire found it the sa spot. If an ndditional scute completed the suries it probalily would bave been the $m$ "IT the present median one, or if two were required to fill the gap (if such a gap exi on. would be on the median line, the other would correspond with No. 3 to form anot piair. The adulition of one or two scutes to the series would result only in extent and possibly llat teuing the eurre"

Tho median s'nte is upparently symmetricul, the others nre asymmetrical, form pairs with reversed lateral proportions.

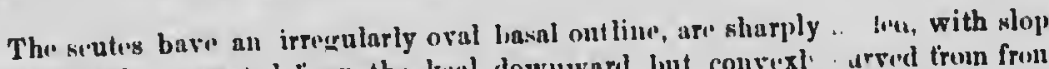
sides shallowly axcavated fron the keel dowuwnel but convexl. arred tremn fron hack, their bisal edeng are defined by an engirdling furrow bolow which, nt n lo losel, they arr luternlly "rgmuded to ment ench other in a plane surfare. A vory wr

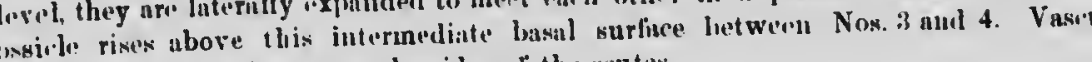
markings are couspicnous on the sithes of the scutes.

From the appearaner of the outer, hassal edgrs of acutes Now. 1 and 5, it kerms $p$

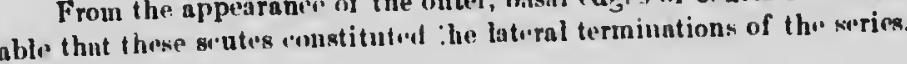




$$
1 .
$$$$
50
$$$$
210
$$

$1: 5$

010

016

have sinue whown nidies irod si'utres, ruir which

the inuer, [red oswin'] isk, th. Njworites

the band of o be intart.

1) 2 was perd 8 the fractheir being of the undirr coin lowt wreu at the same (') the mate a gap exists) form another in extendiug

iral, forming

with sloping liroun frout to l, at a lowיr A viry ninall

4. Vusinular

it ser'ms prob-
Height of apex of merlian keel alvervo then lovil. . . . . .

M.

$\operatorname{lin}$

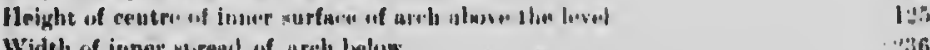

Width of inner mirent of arch below.

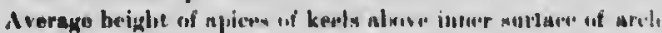

$10 \div:)$

MT:1

11:1

(1)

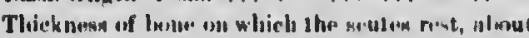

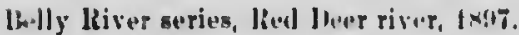

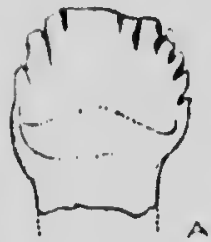

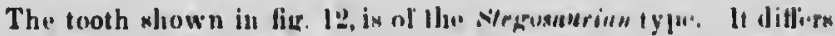

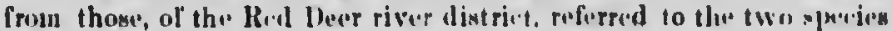

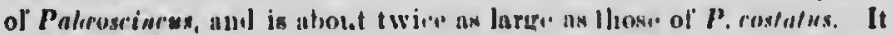
is ligured her" with the id.a tlut it may "seutually pros" (n) lnlong to s. tutux. It was collented below lbirry arenk, on lied buen river, in 1901 .

A mpinous derınal plate of ınaskivi proportions, fig. 13, A and

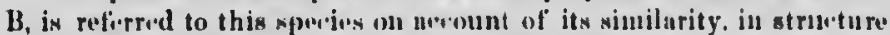
and surfan morkings, to the pontreranial ked.l.d soutes dess.ribed ahos'. This nperimen was rol. lewted in 18:17. Anollu'r larga" plato similar in general proportions to the nhove and menrly as

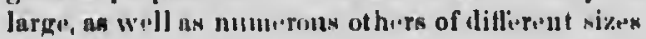
and of a varioty of slaphes, werv collonted in 1961.

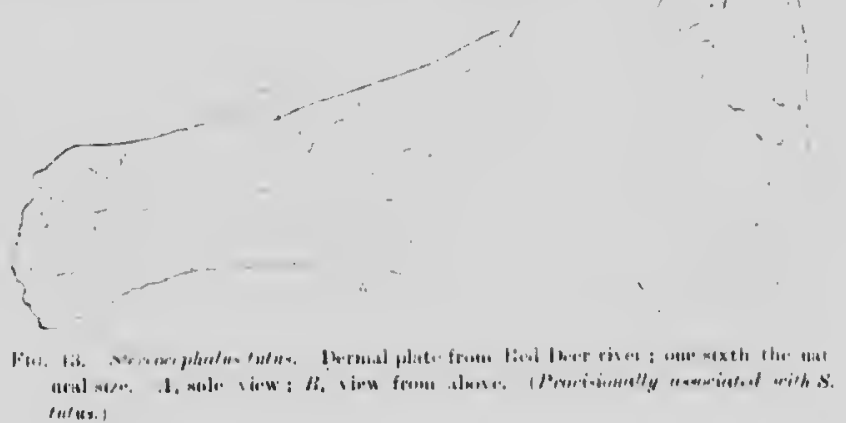

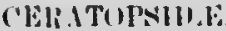

Munochanten, Cunn.

Munichonite Diwsont. Sp. hov.

l'late XVI, platu XIX, figs. 4-t, and plate XX, tign. 3 and 4 .

Th" romains of an appurnutly undescribed species of this genus, ronsisting of the skull of one indiridual and the postorior erent of anothor, are ol peperial interest. Th" 


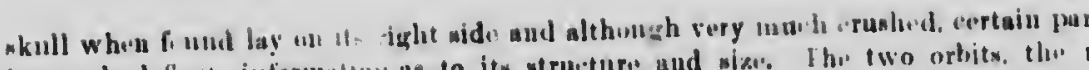

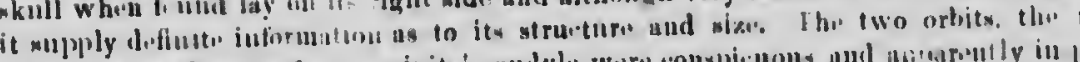

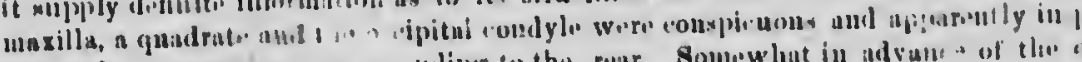

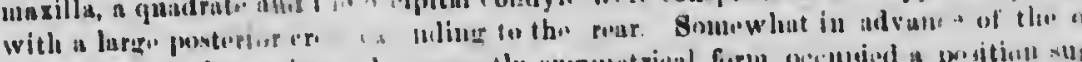

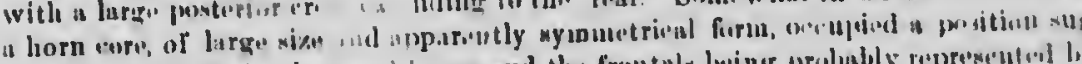

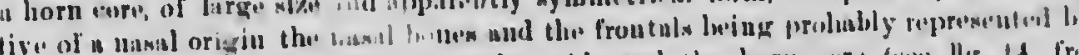

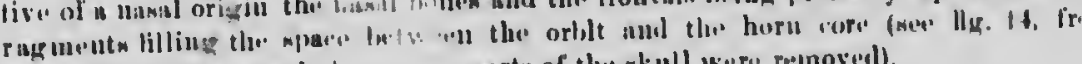

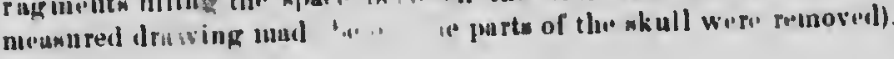

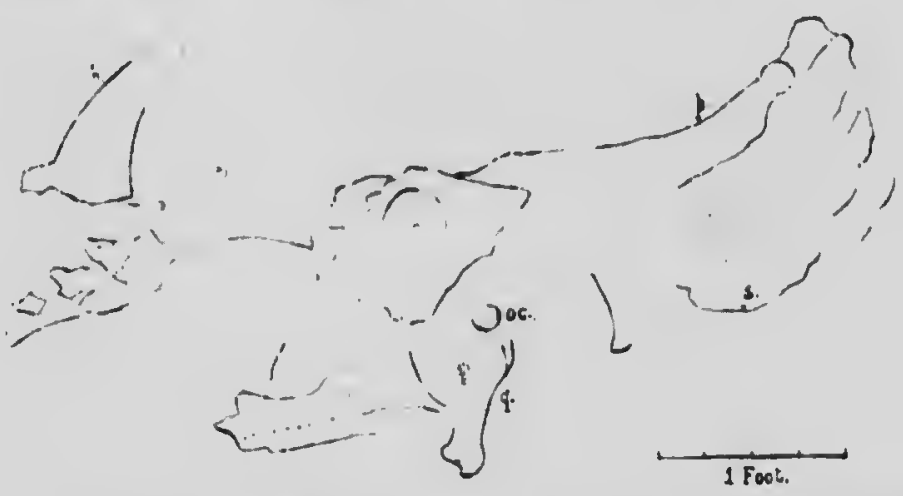

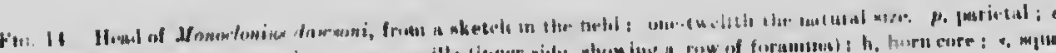

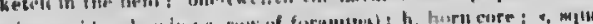

The lurgu [xesterior arent forms the bick part of the skull above; itn axact st fortanately supplied ly the admirably jurserved speciun whown in outline. from be in lig. 15. Tha anrlace of the bone, ahove the orblt and from there inward for distunce tuw arel the median line of the skull, is moderately month and shows un a horu vore.

With the soparute pusterior cremt was fond a horn 'ure, similar in shape 10 , al not as well preserved as, the our bulonging to the skull.

The prosterior erest is composed of the pariefals and squamosals coulesied. The are representud by a llat, thil, smooth median portion that "xpands laterally both

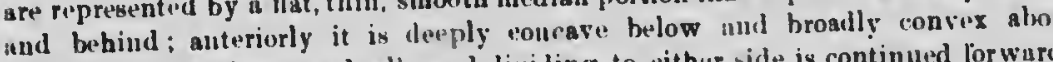
posteriorly it thiskens gradually and dividing to eithur side is continued lorwure squarasals in a broad inrve to meel the anteriur expansisu. 1) either sid. median clenent is incluled a large supratemporal varuity or fontunelle.

The posterior creat is sometwhat aaddle-shaped. Its sides are wavy, with thickening of the buue in the pontorior five of the seven correspondiug collexitie periphery, whilst a pair of inwardly directed spars of hone, with their point alighlly downwurd, are developid ou its posterior border, one ou ach side of the line. The istervaruitul element is thickened along its median leugth and a more streugthening of ibe butse ocetre along the posterior bordor, resiuhling in thi 
-rtaill parta ol its, the risht "nitly in plins. of the ortits aitionll sugar"s amenliol liy the is. 16. Ir.ill it

marictal; $m$, orloil: arre: ". mituanismal.

"zact shap" is 10. from beneath, ward for a short hows 110 tracs of

ape to, although

'ed. The former ally both in lirout avex above but d lorwurd as thi" ther sid." of th."

vy, with a slight nuveritios of th." eir pointe turued de of the median d a more decideal ng in this respert

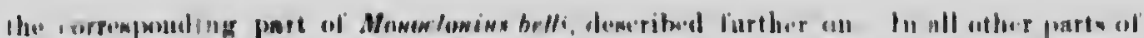

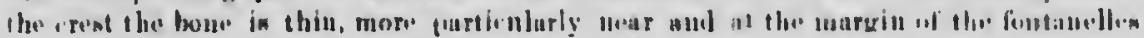

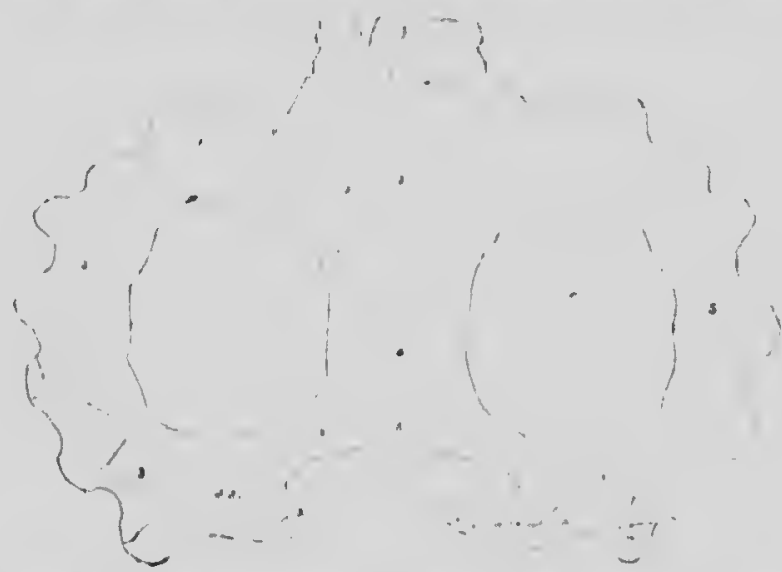

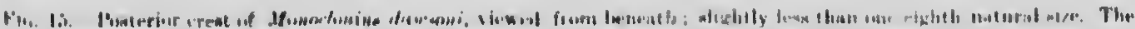

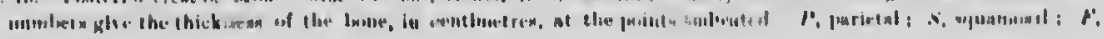

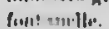

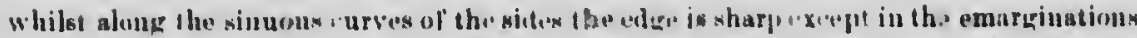

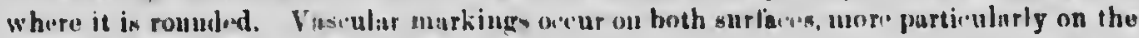
peripheral projections.

\section{Heinuremienta.}

tteight nf orbit.

u.

Width of urlit ...

.110

.045

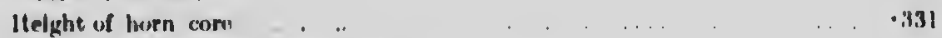

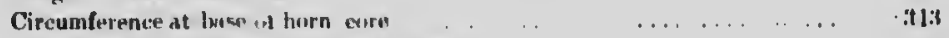

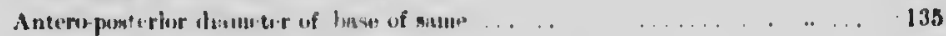

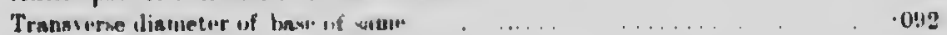

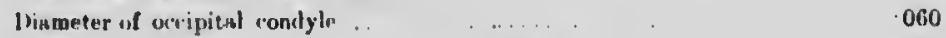

length of maxills . . .... . mprose . . ...

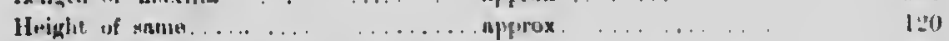

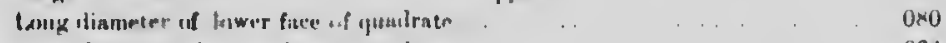

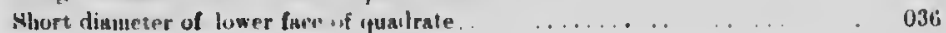

Puaterior crest

Fxtıeuse length frum anterior "mul of apecimen (imperfect), molinlly, ti tine

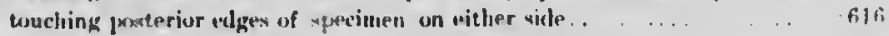

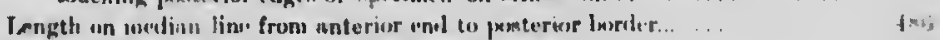

Nemi.breth uf specionen on curse of umler surfume.. . . . . . 4iv

Nemi hreath of speciuen horizontally.......... ... . . ... 439

Vertical drof. of lateral edge of ap eciuen below median line of uleder nurface

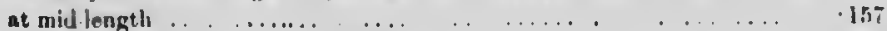

Antera-puaterior dismeter of fontanelle. $\quad \ldots \quad \ldots \quad \ldots \ldots \ldots \ldots \ldots$

Transverse dismeter of fontsnelle....... . . . . . ........ 248

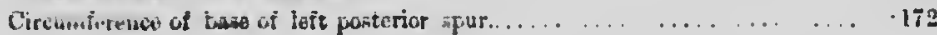


The skull and the posterior crost were pollecterl on Re+t Dior river in 1901.

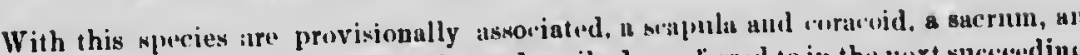

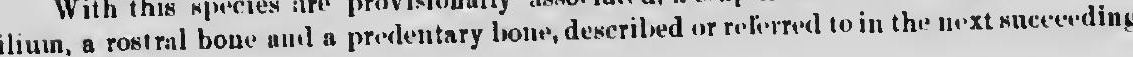
pager.

The suapula with corncoid is ligured on plale $\mathrm{XIX}$., lig. 4 , viewed from its inn side.

The scapula is lone and narrow, slightly coniave insward in the direction of it l.ngth, stout below, thimine rapidly upward. upper end terminating sefuarely, brealt dewrensing toward nid-length, slightly axpanded above, lirut margin thin, bac unargiu broad below, uarrowing to its mid-length thell continuing thin upward. rounded rilge extends noward, on the onter surlanes, diagonally across from the uppe (n)l of the glenoid cavity to the front margin continuing as a din.iled thickening of th front margin ahove.

The cormoid is hroader than high, emargrinated below the glonoid cavity an produced batkward b: low, lower border turned inward, imuer surfare dee idodly contar bu.k border at enareinition inick, border elsewlere rather thiu, rounded. Forame traversiug thickness of upper part, directed obliquely downward and outward, with enlarged outer opening. A suall formmen occurs, below the glenoid eavity, in t] inaraination of the posterior border. Glenoid carity higher than broud, its curre for inir almost a semicirele.

In the spicimen fignred, the coracoid was probahly liruly united with the seapu he sutnre betweell thein, extending from the mid-height of the grlennid aisvily lirws

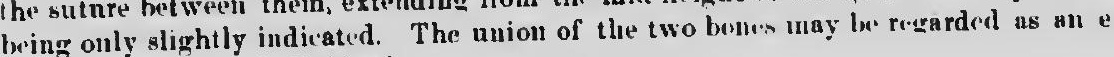
dene' of aere in the indiridual.

The left scapula and eoracoid from the Rel Dis:r river distriet, so similar, in 11 resperts, to that of Triceratops prorsws. Markh, as ligurnd iu the Sixtonenth leport of l'nitud stales Greologiınl survey, differs iu one important partiıular, riz., in having lower border of the cormend turned inward instend of outward.

Sirapula witls corncoid (lift), Cat. Nit. 506.

Extretue letugth of seapula with enracoid in line witl back edga of shaft. . .

.004

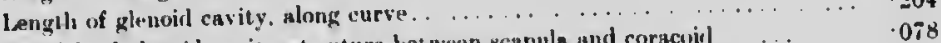

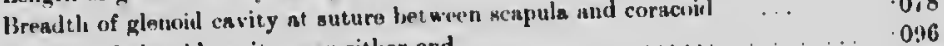

Broulth of glenoil cavity uear either end ... . . . . . . . . . . . .

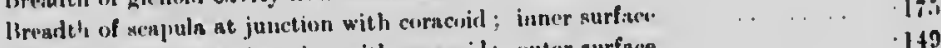

Breadtl of acajula at junction with comcoid : outer surface ... . . . . $\quad .238$

lirvalth of scapula at upper end of glenvil cavity. . . . . . . . .

Brendtl of seapuin at mid.ength $\ldots \ldots \ldots \ldots \ldots$

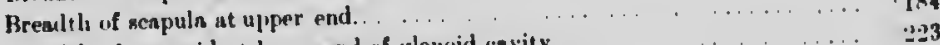

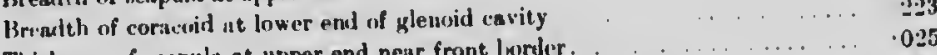

Thickn.ks of seapula at upper end near front lkorler. . . . . . . . . . . . . . . . 060 
Thickness at lower end of phlonoid envily

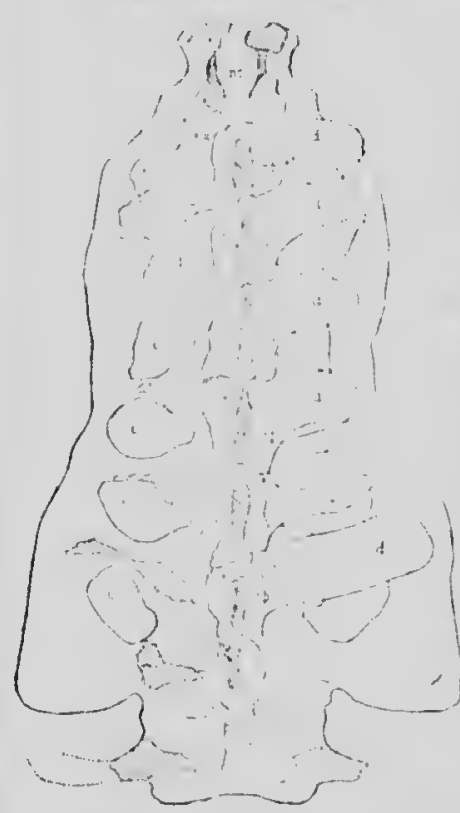

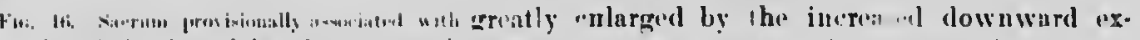

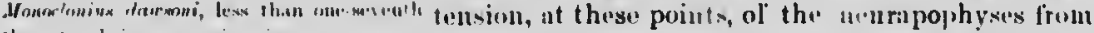

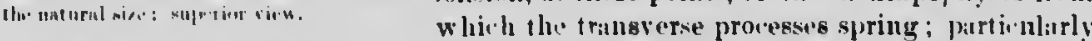
is this the "ase with the second and third "outrit. The distance of the ilial liter from the median, longitudinal line of the sil.rum, dependent on the length of the transverse frowesses and thi broidth of the c. "utra, is much errater posteriorly than in frout; in its anterio: half the fitet is dirented whliquly downward, possibly with solue exaggration due to distortion in the specion.s. The ilin. bar at its midlength bends inward but

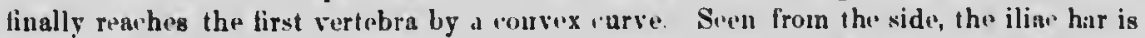
horizontal throughout its length with the exeeption of an npward bend posteriorly. Dispophyses epring from the neural arches aliore and are "onuected along the length of their lower edges with th. transvere proenses. Proximally the snperior snrfaces of the diapophyses are axpanded linterully so as to form a neural platform, the component purts of which are not "onsilied. The prozygapophyses remuin distiunt from the postzygapophysees.

Thu speeimen has been some what crushed in a verti.nl dirution. The dispopliyses have ac iel as wederes and have foreed apart the halves of the transperse processes ilear their basal origin. In figure 17, p. 62, the diapophyses are restored to their supposed 
proper positions and the neural spines, whose bases aro woll preserverl, aro indicated, $h$

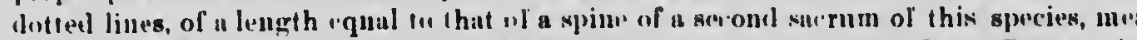
sured in the field. The diapophysin are apparently not lung* "nough to offect a unio

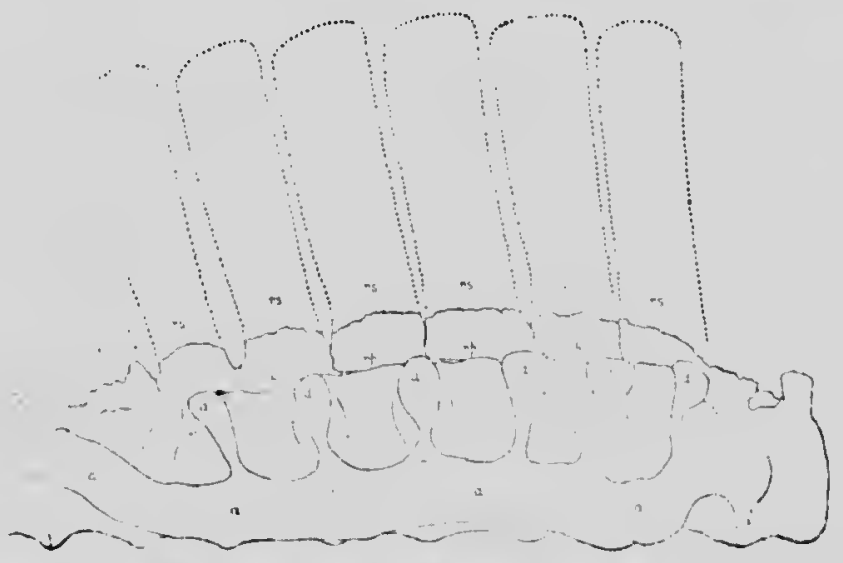

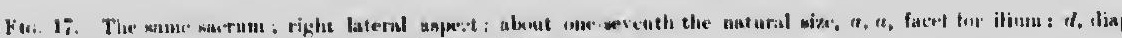

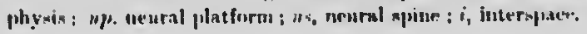

with thr ilimu. It is possible that the conear" purt ol the ilian linet entered into the form

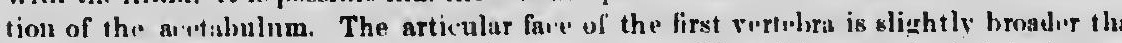
high but in the fare of the last vertebra the exinss of breadth ovir the hioight is mu mor" apparent; the anterior vertehral fan is plane, the pustorior one is llat rerticnl

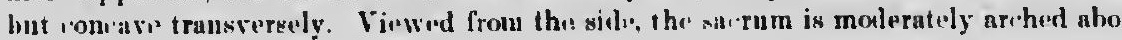
but flat bolow.

Measuraments off kucrum.

Hetreme lenght of sacrum $(: 10:$ inclies $) \ldots \ldots \ldots \ldots \ldots \ldots \ldots \ldots$ itit

Basal length of ist vertelors . . . . . . . . . . . . . . . . . . . .08t

.

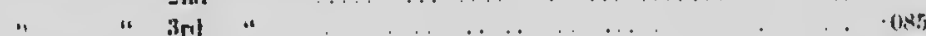

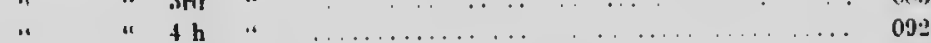

. " ith .

" $"$ fith $"$ "

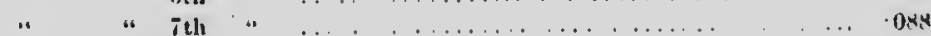

" " $"$ "

" " "ytl "

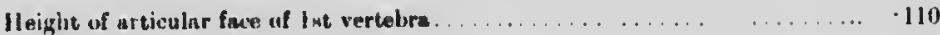

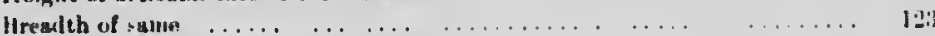

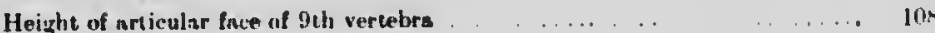

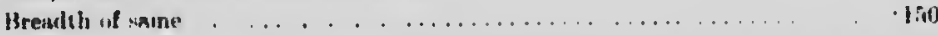

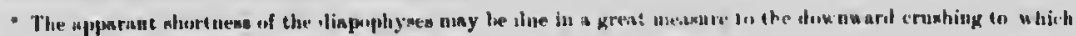
verionen has leen subjecird. 
dicated, by reciess, unus iert a nuion

lium : d. siajmo.

o the formaroadir than rht is muin at vertieully rehed above טis;

UNI

09:3

Uत:

טit

. 1150

.jox

5i:3:3

ט:⿱:

(1).36

045

$-10.3$

1):4i

1):

. $07:$

- 073

- use

150

- 187

Bresitls at juuction of stls with 9 th vertebra

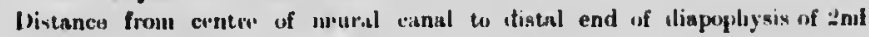
vertribra,$\ldots \ldots \ldots . \ldots \ldots \ldots \ldots \ldots \ldots \ldots \ldots$

Distance to same of ibrl vertebra... . . . . . . . . . . . . . . 115

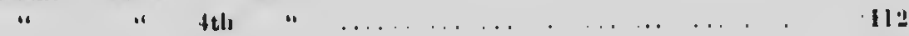

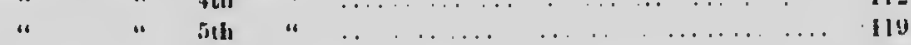

" $"$ bith $" \ldots \ldots \ldots \ldots \ldots \ldots$ 13.

" $\quad$ ith $\quad \ldots \quad \ldots \ldots \ldots$

The rostral bonw. firmrod tu plat, XX, and the small predentary bone (plate $\mathrm{X} / \mathrm{X}$, figw. i and (i) were found soparately and rasy with some probubility of correntures be reterred to this species. A large ilium is figured toward the "nd of this report.

This species is naued in honour of Dr. Gerere M. Dawson, C.M.(i., late birector of tho Geological Survey of C'atuda.

Monuclonire canadexisis. Nip. not.

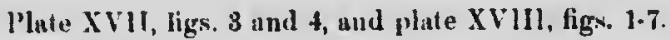

This spmeies is foundod on a supamosal, part of a parietal, a jugal, a supraorbital horn "ore, the lift ramus of th. l"wer jaw, and un anterior dorsil vertebra, with some other parts of the skull, not yot fully determined, of one iudividunl. A right ramus of moth.r individual is shown on plat, XVIIt, and a separate horu core ou plat" XVII.

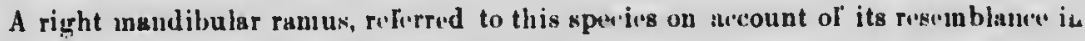
form to th" one shown above, is diesiribed farther on.

The horn rore (tig. Is, pilur (it) rises above the orbit from tho postfrontul of which it forms a part. The post frontal nuites hehind, by suture, with the squamosal and below with the jugnl. The orbit is "xal with the longer diameter vertical, ita npper "urv" lying close wnder tho base $n$ if the horn core, its unargius not ridged. 'The horn core is winull, about $21 \cdot 6$ cont. Ing from the upp'r 'dge of the orlit to its summit and $22 \cdot 8$ 'ent. in circuinference near th, base, eir'nl:ir in section and solid. 
Stpuanosul sumowhut triangular iu shųn, flat, molerat,ly thin, its outer

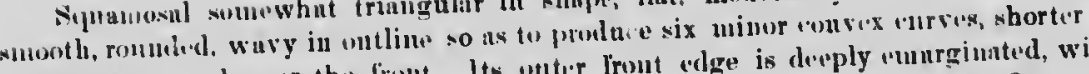

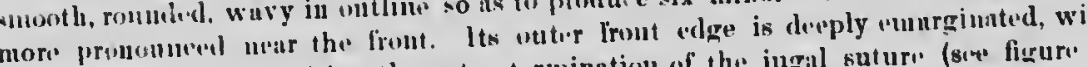

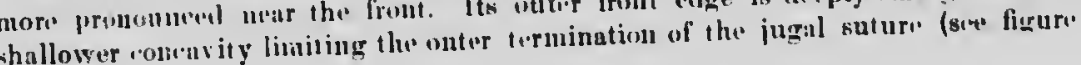<smiles>C1=CC=C1</smiles>
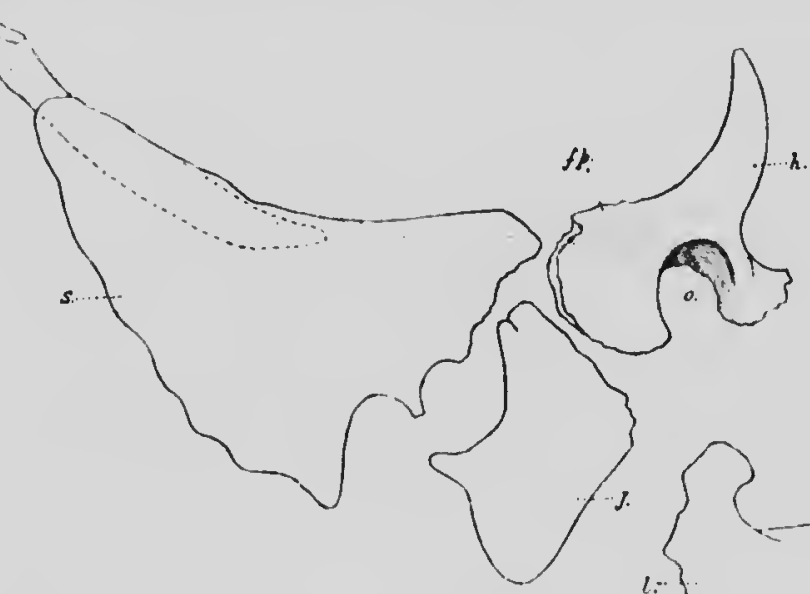

inside of which is the sutule for the union with the postlrontal. The inner bor shightly eneare. The lower surface nearand parallel to the inner posterior end is br and shallowly gronved for the reception of a line. slinder lome, triaugnlar in si that projerets backward and inward, its untor edge continuing the ror

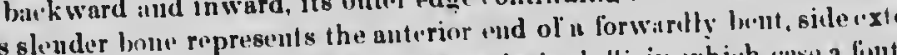

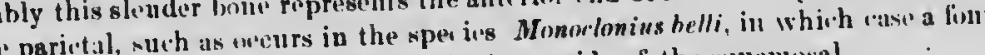
oderate nize might be expertind on the inner side of the stjuamosal

In figure 18 the underlying boun (imperfect posteriorly) is indi'uted by a

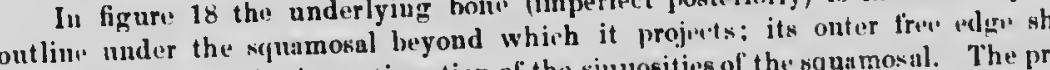
onvexity ill continuation of the sinuosities of the squamosal. "The pr inner margin of the squamosal is bent at right angles to the plawe in which the rein of the bolle lies aml its under surface is deeply exirasated in ils inner front part lo distalle back from the postfroutal suture. 
outer eder. whortur und intod, with a fierur. 1\%),

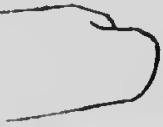

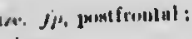
jan.

inner border is r.nd is broadly lar in siction. the sijuamosal. , siderextrusion ":see a fintumell."

ted by a dotted - adgu shows a The proxiutal h the remainder nt part lor rons"

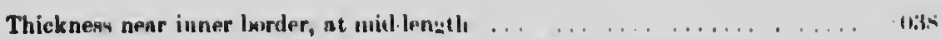

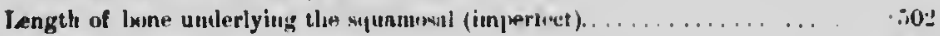

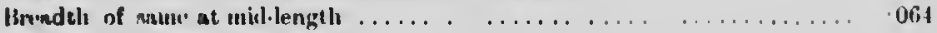

Greatent thicknesw at mill lougth. $\ldots \ldots \ldots \ldots \ldots \ldots \ldots \ldots \ldots \ldots \ldots \ldots$

With the parts of the hrad, sbown in lig. 18, was also found an anterior dorsal vertebra (fig. (!)), of rather small size. Th" lames of tho centrum of this vertebra are slightly concuver.

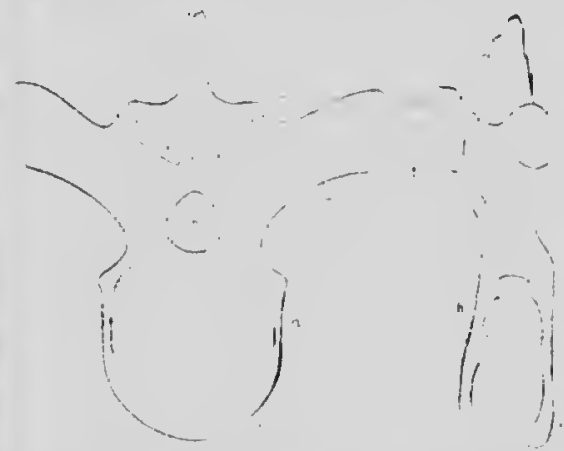

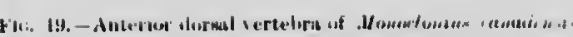

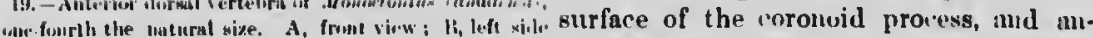

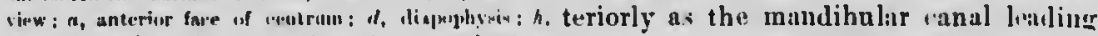

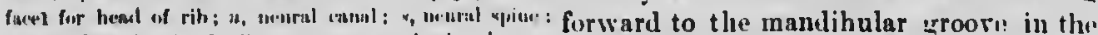

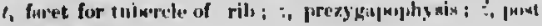

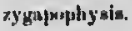
lower border. The dentary canal, betwern theouter alveolar wall and the outer surface.

enters from the upper and anterior part of the excavation by a large opening. Coronoid process stout, upright, hooked forward and flattened laterally abore, its outer, upper sulface :agosely striated. A broad, low rillar, least defin.d toward the centre, runs at ahout mid heigth, along the outer side, tb+ surline, in a general way, ahove and helow, retreating obliquely inward. The dental chamber, straight, starting at a low level behind, inclinel strongly upward and slightly outward toward the front, its lower odere making an angle of about $20^{\circ}$ with the lower horder. Alveolar irroves in onter wall ol iluntal chamber, desply impressed toward their upper enls by a second neries ol groove fermiulitions, an evidence of two roots in the teeth, belontring to this jaw, wu.h as ur, wharacteristi, of souse of the speries of the Ceralopisile (Igathumidr). Hoight of dintal chamber mush redared forward. A number of large forimina present in the outer surtiae. Front border. it viewed from theside, sinuoas, rugose for its uniou with the predentary houre. Twent throe alveolar grooves are prosent in the dental chamber (imperfiet posteriorly) of 1 li." sperionen figured. A sumall symphysoal surface is present is tho frout, liwer bordir.

\section{Measurements of ramus of lourer jurt.}

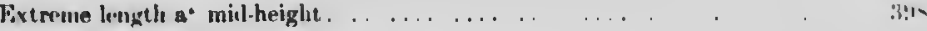

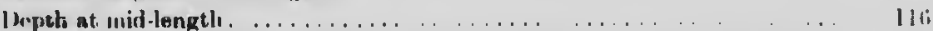

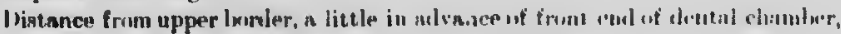

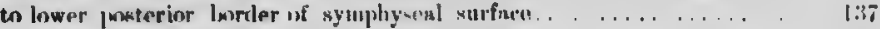

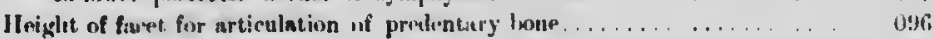

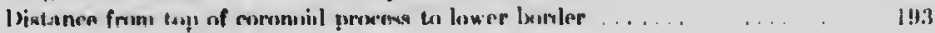




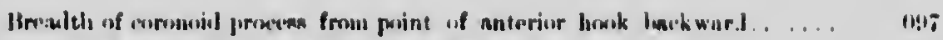

Thickuess at mentro of upper enrounidal expansion. . . . . . . . . . 11.24

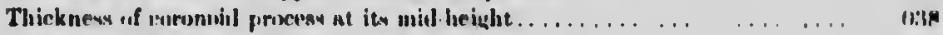

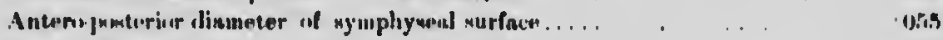

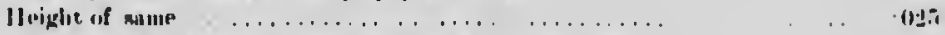

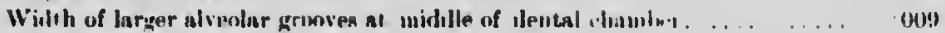

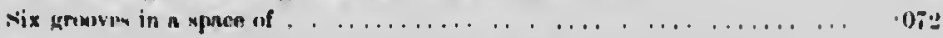

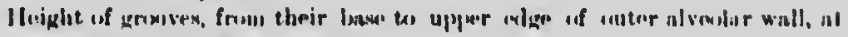

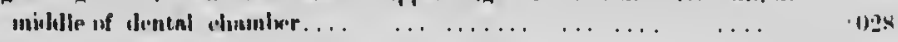

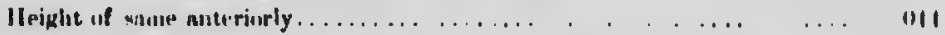

A maxillary bone (not fignred) with tweth that are donhlo fungul, is reforridl to tl spuriers. then of the terth is shown mu plate XVIll, figs. 3 and 4.

A s: purate tooth. presumably from the lower jaw, is alsa fienureal on platt! XVIII. wax fonud separatoly. but on ac'ount of its having two rosts, agrening thus with 1

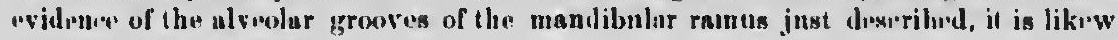
rofierriel to $\boldsymbol{M}$. cinnulensis.

MoNistontes urtar. Np. Hov.

Plate $X X$, figs. 1 and :..

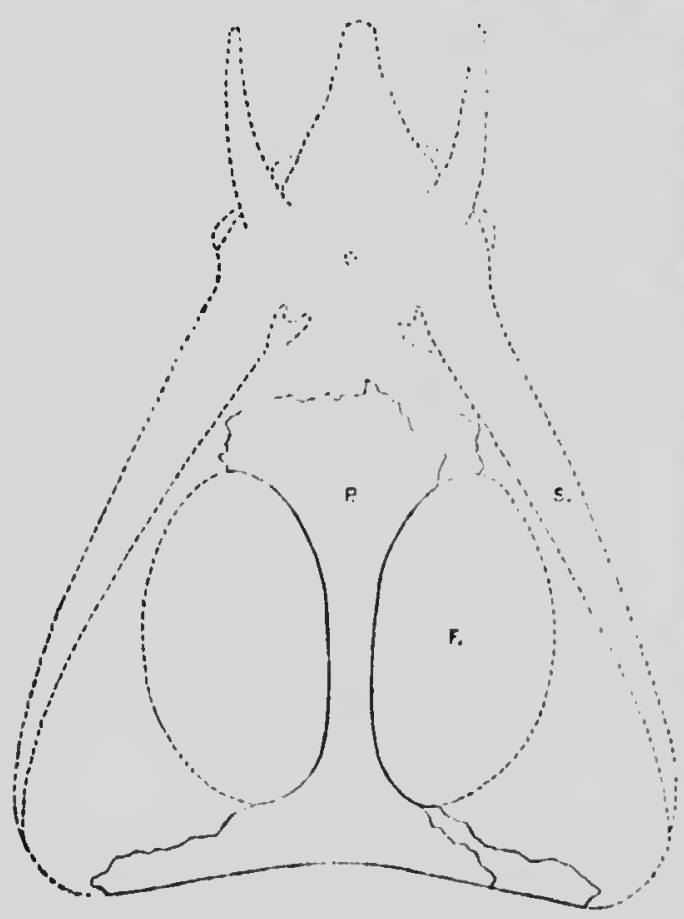

The loure, fignred on the nler plate, is interpreted as representi the coalesered parietals of the $\mathrm{n}$ Irrior erest of an nundescrit speries of Mumorlenius, prohal alu'istrul to such lat'r forms Torosururus latus and T. gladius: Marsh, from the Laramie, of $\mathbf{W}$ ming.

To farilitete an understandi of the viow held as to thr positi the parietals probably o'cup relutive to other bonis of the he a drawing of the bone, has bu applind to the fignre, slightly n dified, of the sknll of $T$. gladius givent by Marsh, in the Sixtend Allnutal Report of the l'uitud Sta (Hological Surviy.

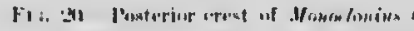

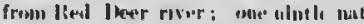

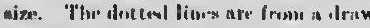

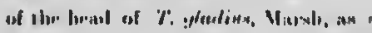

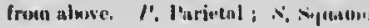
F. Fintindile. 


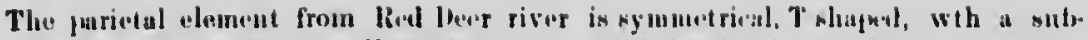

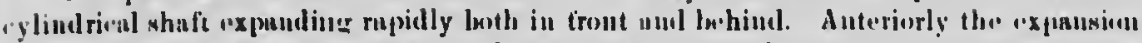

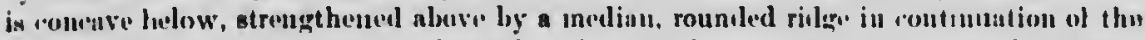
contral shatt, und thiming out luterally. I'ost.riorly tho shalt divides, warly at right

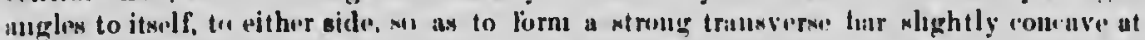

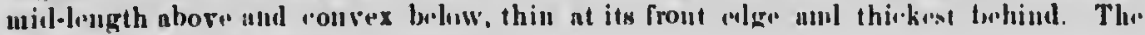
posterior border is augularly roundorl

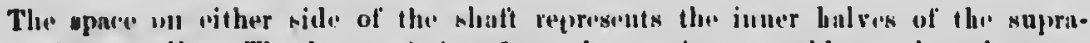

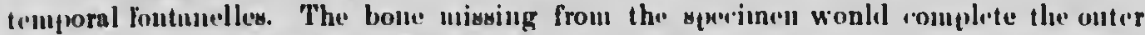

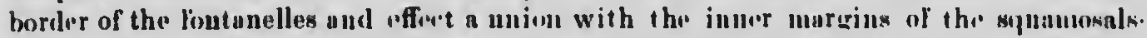
The lower fare of the anterior expunsion, on wither side of the nudian liue, is strintol by lintinct furrows that follow down the lower laterul sides of the shafi, as diep igroovis, and anre outward on to the trannversi bur. The antorior upper surlines alsu rexhilita similar grooves that do not, howiver, pass heyond the mid-longth of the shath.

The pariotal, impurfect at its anterior end, is wout whethird the visu of that uf $T$. shludius and would prohably raprosent " proportionatoly smiller animal, an earlier and

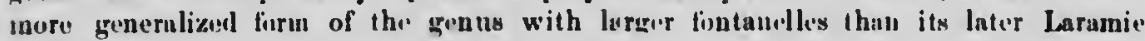
sllceresers.

$$
\text { Hosurements of perientel bouse. }
$$

II.

I.K4

.173

$\cdot 305$

( I)

- Ori.:

. 0.53

.041

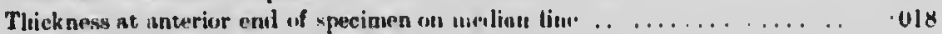

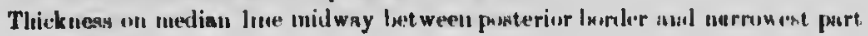

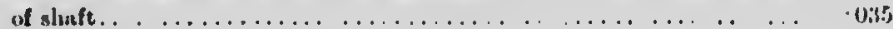

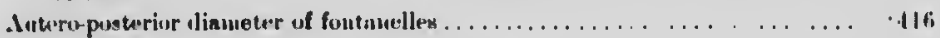

Belly liiver stries, Rod Doer river, 18!k.

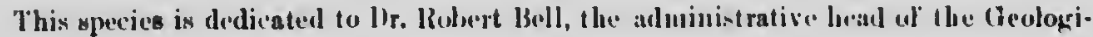
ial Survey. 


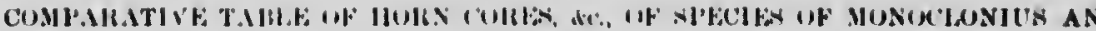
[MIIIIUNAX.

\begin{tabular}{|c|c|c|c|c|c|c|c|}
\hline & 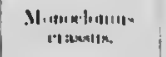 & 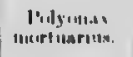 & 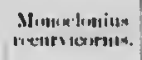 & 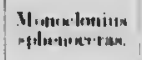 & 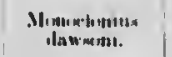 & 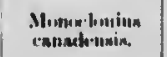 & 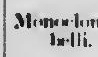 \\
\hline $\begin{array}{l}\text { Nanal } \\
\text { lourir. }\end{array}$ & & & 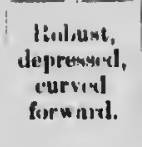 & $\begin{array}{c}\text { Iange, } \\
\text { strwiglit } \\
\text { latorally } \\
\text { coni promerel, } \\
\text { upriglit. }\end{array}$ & $\begin{array}{c}\text { Mlonder, } \\
\text { himis very } \\
\text { ulightly } \\
\text { curvel luick- } \\
\text { warl. }\end{array}$ & & \\
\hline $\begin{array}{l}\text { Urbital } \\
\text { hurn. }\end{array}$ & 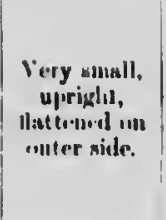 & $\left\{\begin{array}{c}\text { sulprixmed } \\
\text { horrux hiung } \\
\text { nuul } \\
\text { sleniler. }\end{array}\right.$ & $\begin{array}{l}\text { liolsust, } \\
\text { short Hat } \\
\text { telled ont } \\
\text { uuter side, } \\
\text { upriglit. }\end{array}$ & & None: & $\begin{array}{l}\text { Mudernte size, } \\
\text { alender, } \\
\text { curved } \\
\text { clilipuely } \\
\text { inward and } \\
\text { beckwart: } \\
\text { lawo over. } \\
\text { hangn orbit. }\end{array}$ & \\
\hline 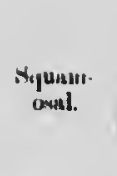 & 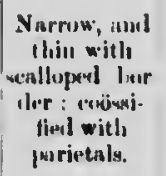 & & & & $\begin{array}{l}\text { Thin, with } \\
\text { wealluned } \\
\text { Inomler ; fewcr } \\
\text { rmarginations } \\
\text { than in } M . \\
\text { cranaus. }\end{array}$ & $\begin{array}{c}\text { Plato like; } \\
\text { lower jumber. } \\
\text { ior lorder } \\
\text { mlightily } \\
\text { scalloped. }\end{array}$ & \\
\hline Hurit tals. & 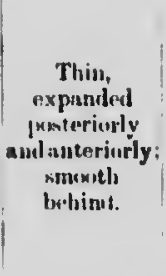 & & • & & $\begin{array}{l}\text { Thickened } \\
\text { posteriorly; } \\
\text { with two } \\
\text { incurved } \\
\text { lonks on back } \\
\text { border. }\end{array}$ & $\begin{array}{l}\text { Known only } \\
\text { trom the pou- } \\
\text { cerior right } \\
\text { lateral exten- } \\
\text { sion partly } \\
\text { undorly. } \\
\text { ing aquanmomal. }\end{array}$ & $\begin{array}{c}\text { Reveray } \\
\text { nhriper } \\
\text { haft nu } \\
\text { lindric } \\
\text { anterior } \\
\text { paninio } \\
\text { thin, p } \\
\text { cerior } \\
\text { panuion } \\
\text { like. }\end{array}$ \\
\hline Twet h. & $\begin{array}{l}\text { I Niuselo } \\
\text { fandedl. }\end{array}$ & & & & $\begin{array}{l}\text { iSingle } \\
\text { fungesl. }\end{array}$ & $\begin{array}{l}\text { Duulile } \\
\text { Pangel. }\end{array}$ & \\
\hline
\end{tabular}

Nringceras. Gen. nor.

Stroncelias VautDUN. Sp. hov.

Plate X.XI, hig\%, I-.).

The two syminetrical, compa't bones, represcated on plate XXI, were found separat Thr lowir portious of their sifles, as well as their ends, consist of sutural surfaces, in "ating that other hones wire firmly united to them and completely surronnded th A trausverse suture divides 'ach almost equally into an unterior and a posterior half. the lower surlace there is evidence of a line of coalescence in a longitudinal 1 , tion extending from end to end. The upper snrface of each sperimen is dome sb: ., . 
In the larger apeerimen the anterior "and is provluced lorward and is alightly elovated

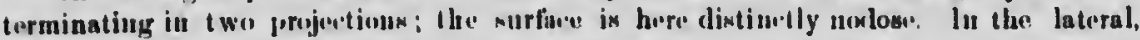

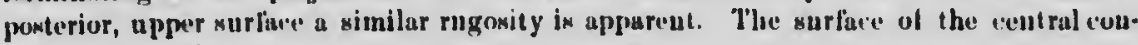
vexity is smooth.

In the smaller speriment the upper surlia.e is amooth und pitted throughout. It is trilohed posteriorly and is not prodned forward in lrout where, however, two suall nodes oxeur, one on ench side ol the inedian linn.

The structure of the lowir surfane is marked by a unuther of smooth, comave ureak,

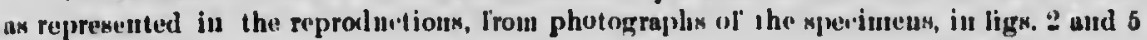
of plate XX1.

It is probable that these bene's were nituated in the median line of the head, in adrance of the nasals. The'g may have belunged to a speejes of dinosanr not otherwine repremented in the collections from lied lwer river and, julgring from the ditfirente in shape

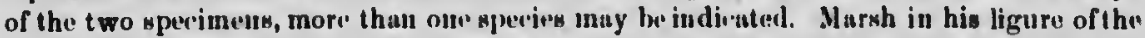
head of Triceratops serrules* whowix a nawal horn core jdirided Isth trankversely and lougitudinally by untures) that inay correspond to the aperiments from lied Deer river.

A third sperimen, similar to the anterior half of the larger of the two hones was colleeted in $1: 101$. It has separated from its posterior half uloug the liue of the transverso suture.

For them bones the name Stegoreras ralidus is proposed with the hope that linture discoreries :n.ty aid in a clearer understanding of their affinitiex.

Belly River seriew, Rud Deer riv'r. 18!8, 1!101.

\section{TRACHODONTID A.}

Trachudon, Leidy.

Trachodin (Ptemutetox) aetowya. No. not.

Plate 11I, figs. 2 and 3.

This species is established principally on the urideure of teeth, of which a uumber from the lower jaw are shown on plate lil. The teeth follow ewh other, quincnucially in the unual Trachodon mamer, three or four occurring in the vertiral series, but seven or cight can be countel obliquely. They replare each other from the inside and appear in the grinding surface in two or three functional rows. When three teeth belonging to the sann vertical row are in nse in the grinding surlane at the same time (see fig. 3 of plate III), the nutcr one is generally sorn dow to thi. root and the stump is ready to fall out, the middle one is abont half worn down, whilst the inner one is either just coming into use or in only slightly worn.

Th $\rightarrow$ teeth of this species differ from those of T. mirahilis, Leidy, in heing rounded oval above, instead of terminating in a point. They are smooth in both apecies. A fow

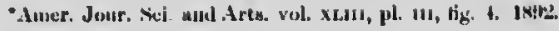




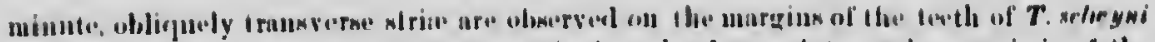

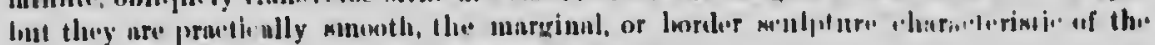
toull of the wpecies dem rilued in the next lollowing panes lwing aloment.

A fow, very large mundiloular rani withollt

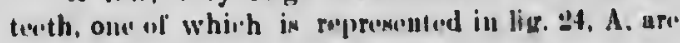
wuppomed to lweling to this mperios.

A fionnr, proviaionally assm.infied with $r$, xplengni,

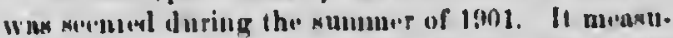

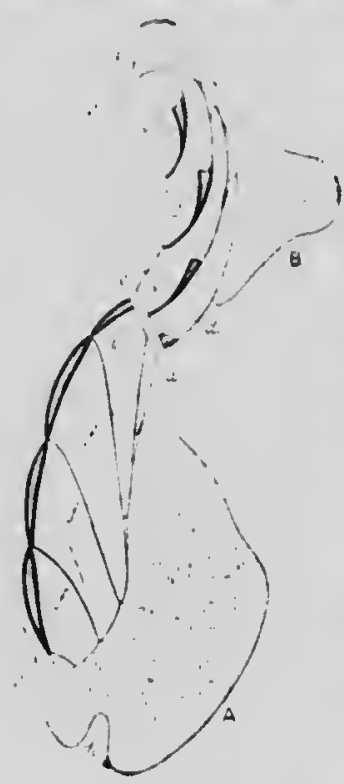

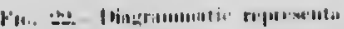
(ime of the grom the of tecth in

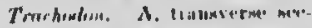
limo of (lio manlifular ramus : lb trimsserse mentioul of the llats.

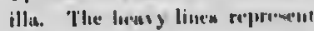

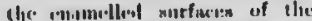
prom un uf the tee (l), re grintling murfacise i d, numell witn lavel : $r$.

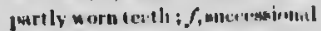

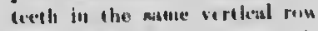
with $d$ ant e: $: /$ forallen: $h$ inantinlular grewene: $i$, inver $w$ ul of fleutal chauller roul ahout 1.4:5 . II. (ivi iundins) in lingth when perlinel it is and $\operatorname{sins}$ M. in .ireum. forenere alsore and Ine low the third ireshanter respretively, and indi. 'ater the sime attuinied by some of the herbivo. rous dinosaurs during Mid-Cretacious timew. For th. purpose of com. parison a reduced higuro of this innenese lone in qivell with a similarly reduced ilrawine of the limenr of Iewemelun manlelli, ("will, from the

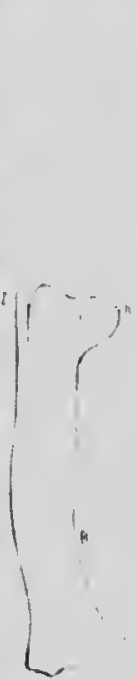

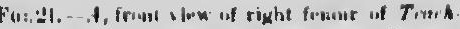

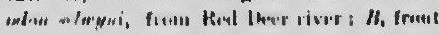

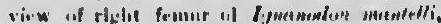

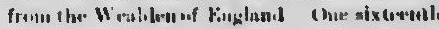

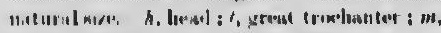

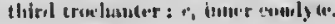
Wealden of Filgnte. Forest, Sussex, Euglanel (seve fin. :I).

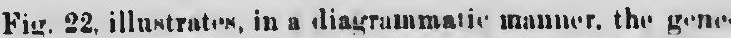
ral mode of suceressiou of terlh in the grenus Trachedon. The lieth ure represented as they appear in trankrerse sintions c. the jaws, the heary lines indionting the kereled enamellen 'rowus of the trell. Thus although in loth the "1pure nue lower juw the leeth replane wah other lirom the inner side. yet the "llamelled surface ol the irown of the lieth are of the inner side in the lower jaw but on the onter side in the maxilla.

Witl this spereies is connected the umne of Dr. Alfrec R. C. Nalwyu, C.M.(r., for many years, prior to 18 ! 4 , Directo of the Grologieal survey. 


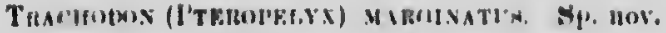

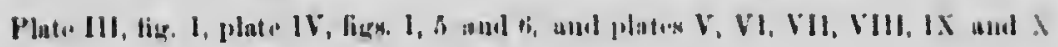

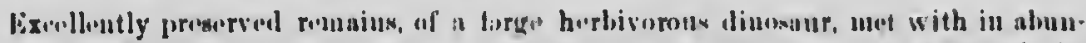

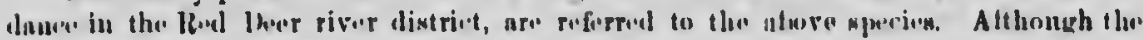

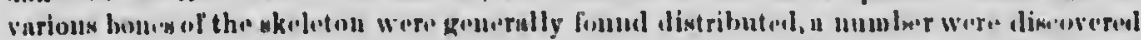

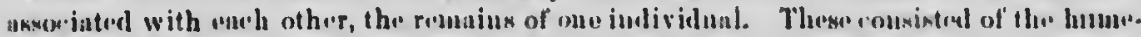

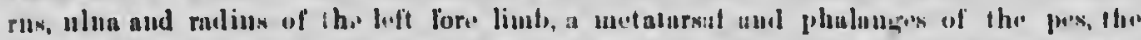

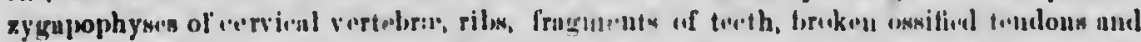

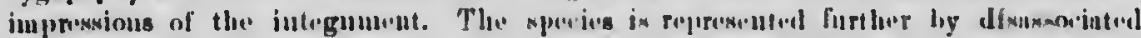

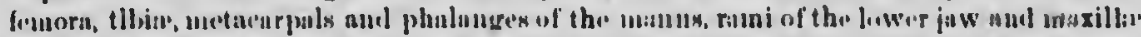

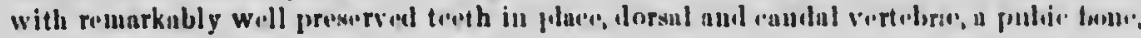

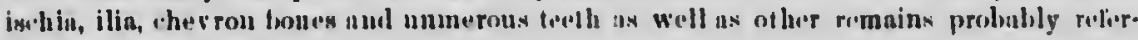
ablo to the same s[recics.

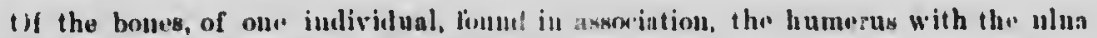
and rudins are figured on plater VI alli VIl.

The humerns, figs. I and 2 , has i prominent radial irent that exfonds, from the exforual taberosity above to slightly nore thou hull wuy down tho shaft extermally and is roughly

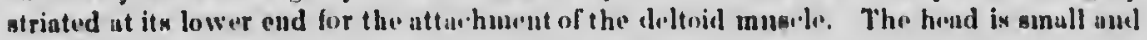
is supportod below by a strong romuled ridge. The proximal eud, seru from alove, is

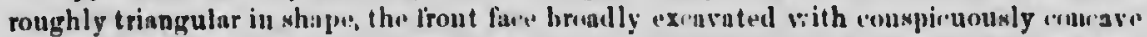

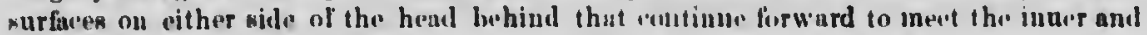

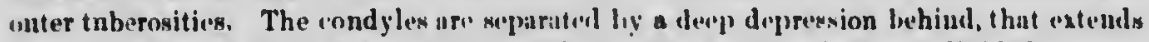

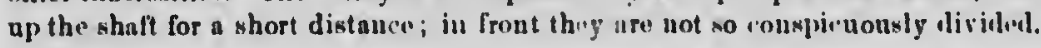

An arehaic fiature is cxprewsel in the grout downward extencion and ronspirnons nugularity of the radial irest. In rompariug this humerus with that of J/adrosnurws fowlkii, Leidy, from the ('rretureous of the east, n form allied to this speries, a unrkil diffrence is noticeable in their proportions.

\section{Mensurenents: rof humerus.}

M.

Hixtreme length (di inchus) $\ldots \ldots \ldots \ldots \ldots \ldots \ldots \ldots \ldots \ldots$ fis:3

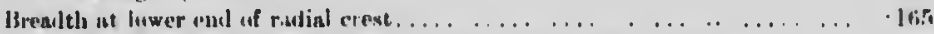

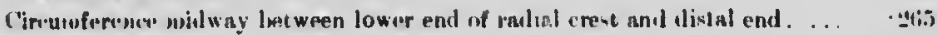

limaltli across heoul ind outer tuleresity.................. 110

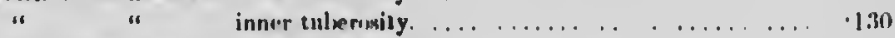

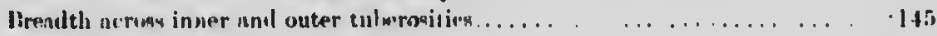

lirealth of outur conslyle . . . . . . . . . . . . . . . . . . . . 100

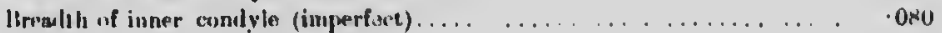

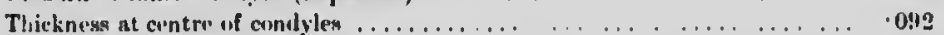

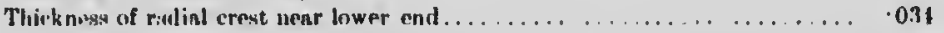

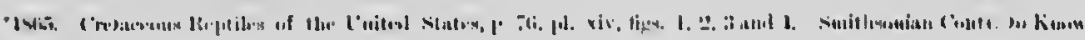
levlye, vith. xiv. 


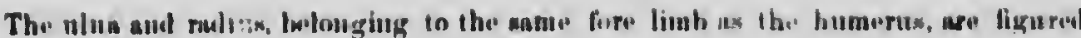
an they wore funnd.

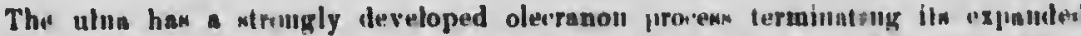

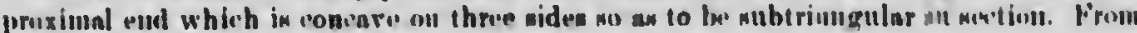

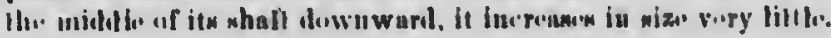

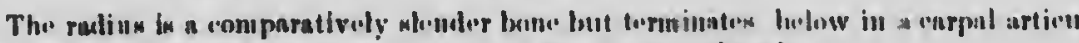

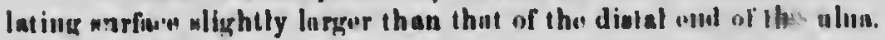

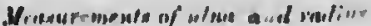

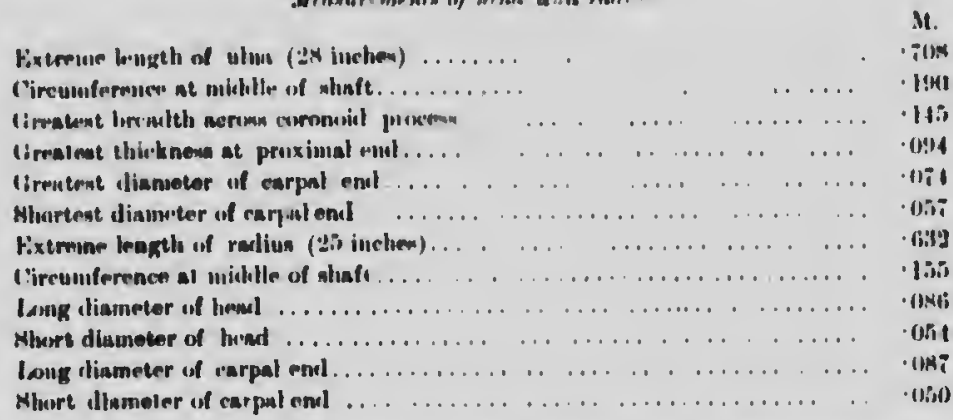

The right femur, plat, VIII, provivionalty ansorinted with $T$. marginatus, in interegtin in many particulars, notably, its slendernese, the prominonco of the head, the harkware extensiun of the condylem insl the inarked desolopiment al the third trochanter. Th

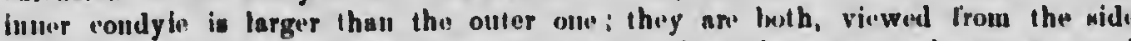

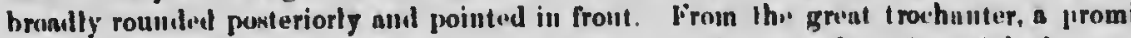
nent ridge exteuds dowisward, for sone dimtause oll the outer front tare of the bois".

\section{Mecururemende of fomur.}

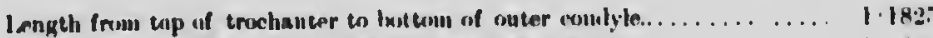

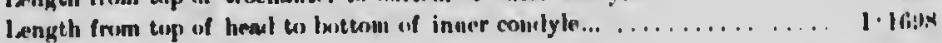

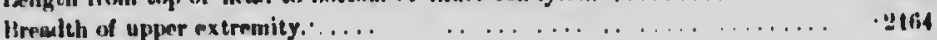

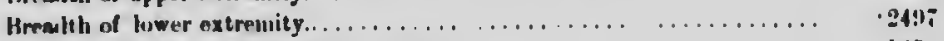

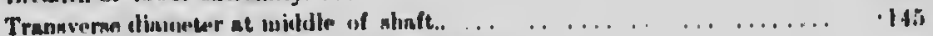

Antorn-ponterien dimuetar at midtlle of whait. . . ........... 131

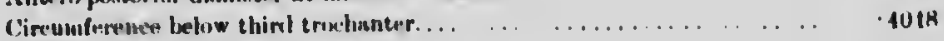

Circumference above thimd trochanter.................. $447 i 4$

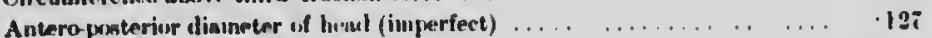

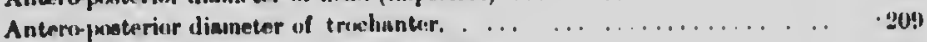

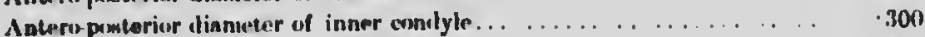

longth of thirl trochanter ...................... 378

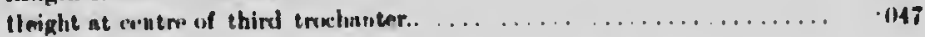

A comparison of this femur with that of Indrosanrws fow'hii, foidy revents a cron similarity in their general proportions. If anything, the Rad Derer river specineu is mor slunder bnt otherwis. there are 110 very markied dilferences. 


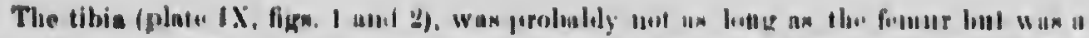

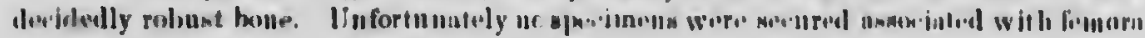
that miglit be suptomel to belong to tle' ma une individunl.

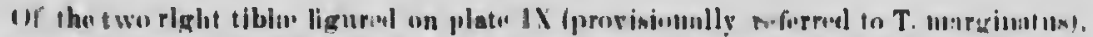

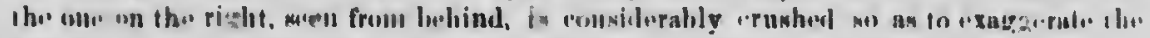

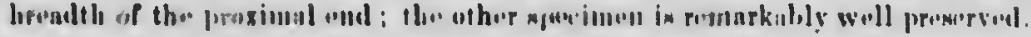

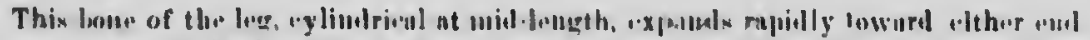

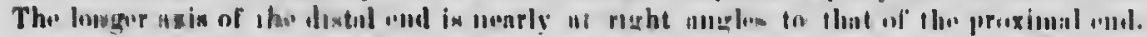

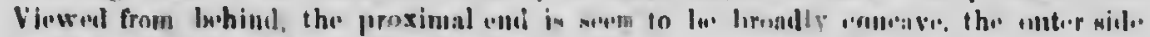

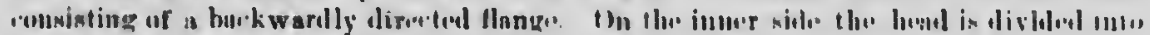
Iwo gurt by a devep firrow.

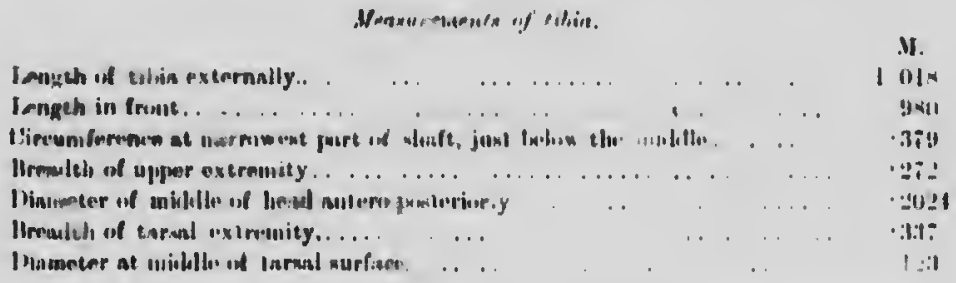

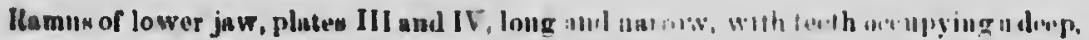

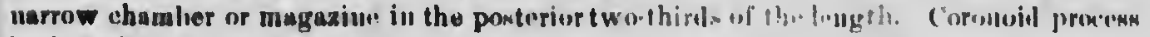

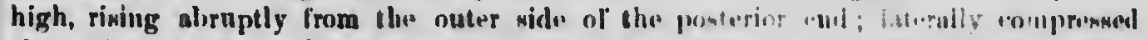

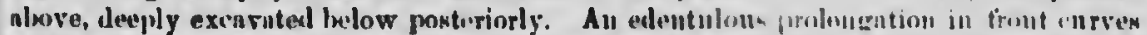
obliquely downward und inward with a wymphymal nurfuce ut the inıer for evar! "mul.

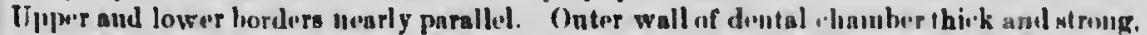

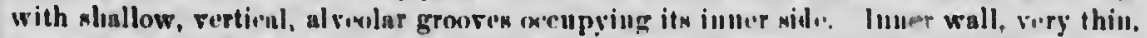

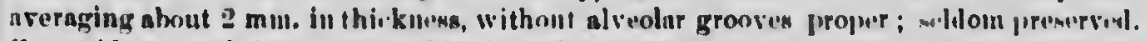
Coronoid proses below, produenl haverarl externally as a thin plate of lone contiunous with the onter surfare of the jaw : on its inner sid. it unites with the outer alvewlat wall in alvance of the pusterior end of the dental thamber. Dentary anal learling from the upjer part ol the posterior cavity forward hetween the outer surfare of the juw nnol the dental chamber. Mandiloular groov" passing forward undier the Inwer lorder of tho

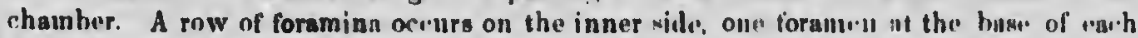

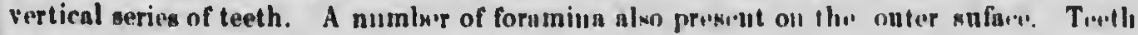

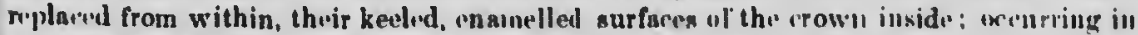
a vertical series of three or lowr near the mildle of the juw with iwo or thro of a sirite

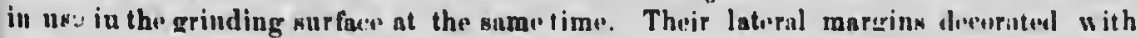
small, rounded projections from uear the apex downorurd to whore the torown berius to narrow agaill.

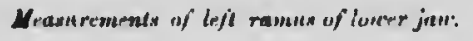

II.

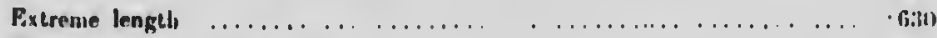

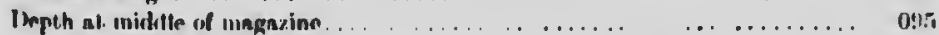

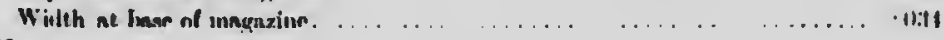




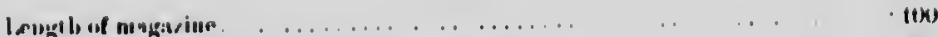

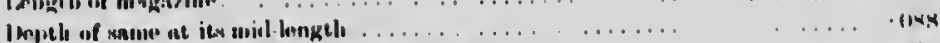

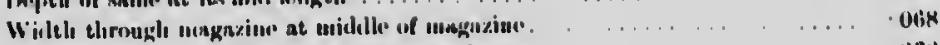

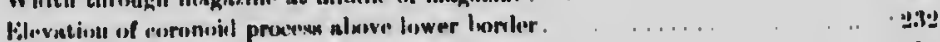

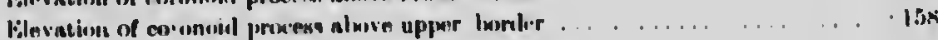

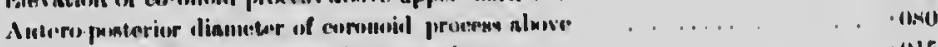

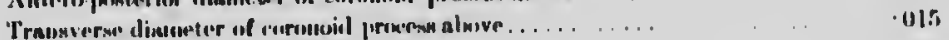

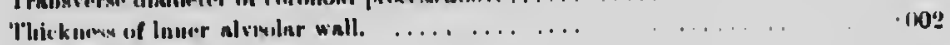

Forign-aix alvemilne gruwere.

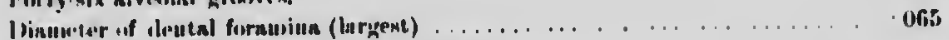

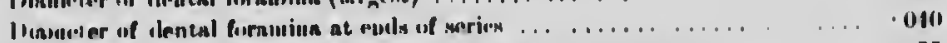

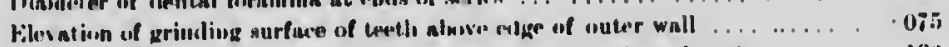

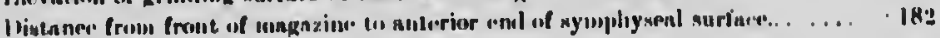

Marillu, plule V, rohust, high at tho rentre, sloping dowuwned rows reither in

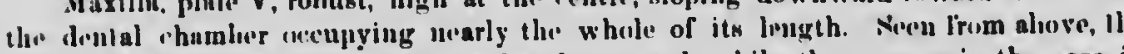
posterior half slopes obliquely forward and out ward, while tho roverge is the rase Iront; at the axtrome nuterior end there is a limited stope ineliumd ubliquely ontunr A lao, riewiol Irom aloove, the posterior half is straight and broadier than the front hi which narrowe to a rounded, ontwurbly turmed point. Inner nurfare rnther flat. Ont anrluc" with a roumlind ridge rauning horizontally from the posterior and lo ineet t] facet for the arlinenlation of the anterior end of the jugal. (On llee innor, upper niale bibit mid-lenglh, a farit, probably for the palatie, is present. Trell roplacing each other fro the inner side, npparintly not more than two ol sories in use in the grinding anrfan

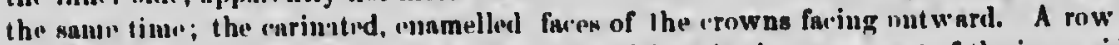
lorumius, similur to that of the lower jaw, conspicious in the upper part af the julur sie Niverul large foranina on'ur in the allorior half of the outer side.

\section{Meauremente of vigh marilla}

.I.

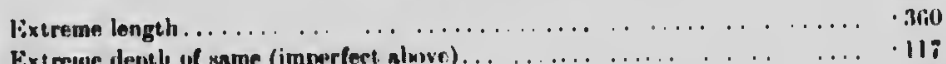

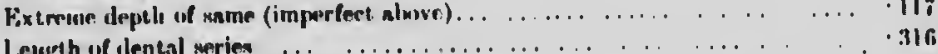

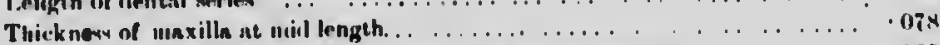

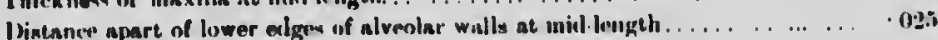

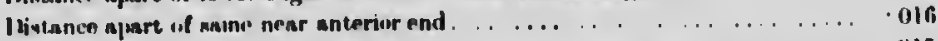

Distance apart of nasue neatr powteriur end ................ . 015

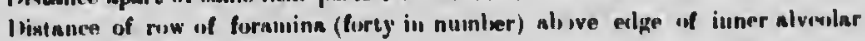

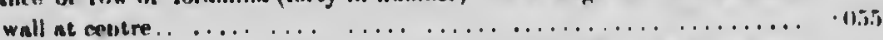

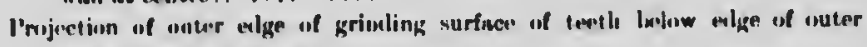

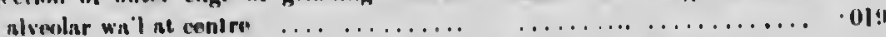

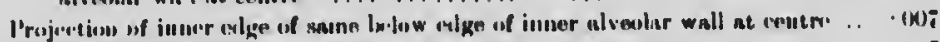

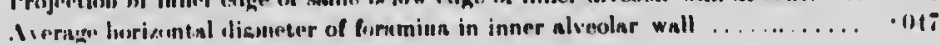

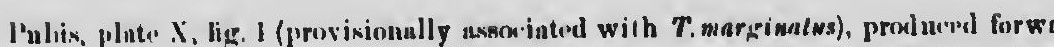

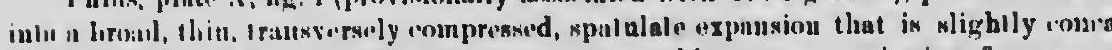

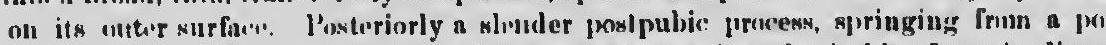

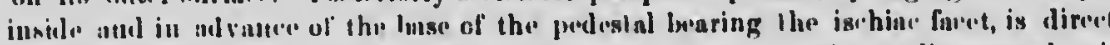

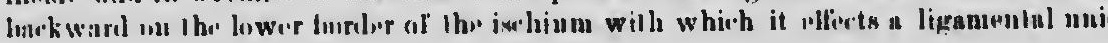


rither ond. 1 aloove, the he rase ill ly outward. c frout half Mat. Onter to ineret the sile brhind other from surfane at

A row of "inumer side.

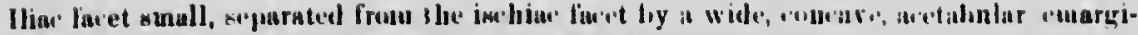

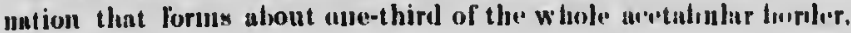

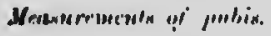

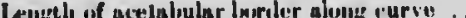

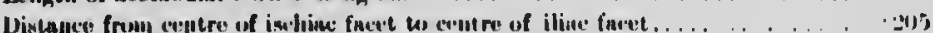

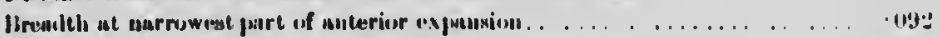

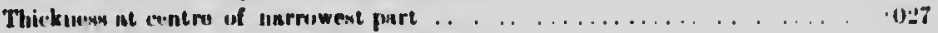

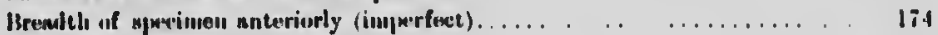

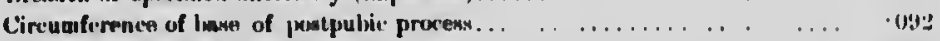

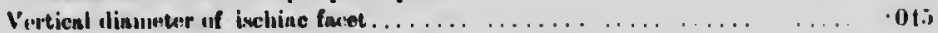

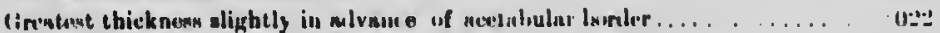

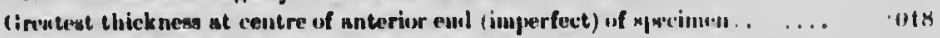

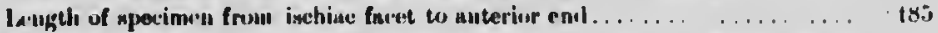

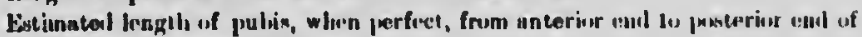

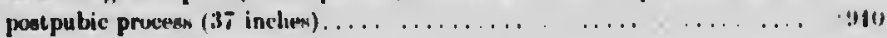

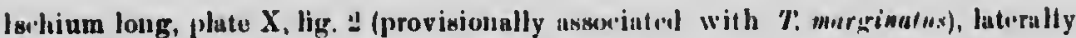
coupresesed, broally expanded proximally and anding distully in a lemet-shajuel extresuity pointing dowuward. Shaft almust straight, its upper algo e'urviug ancurely und broadly upward to meet the iliae fanet l'puer expauded pirt viry thin, plate--like, thickened abruptly, on either sidn of the thili, colware edge of the aredabular torder, to

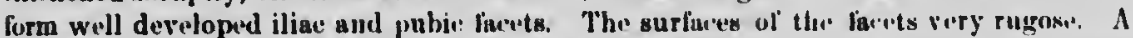

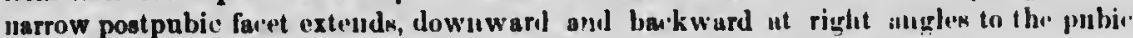

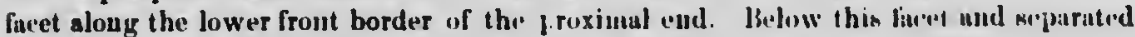

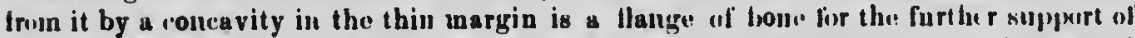
the postpnbis. Inner surface of distal half, slrinted longitudinally lor a ligumutal uuion with its unte of the "pposite side.

\section{Yeasurements uf ischinm.}

II.

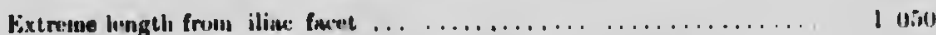

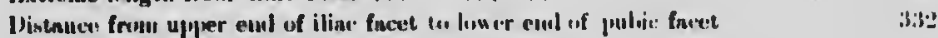

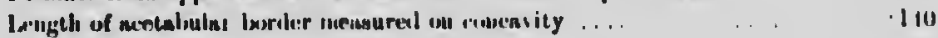

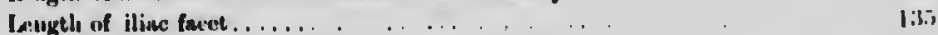

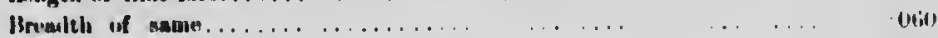

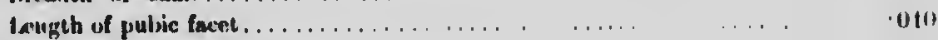

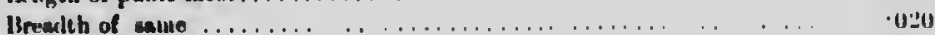

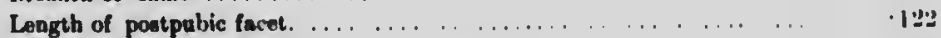

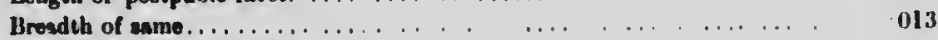

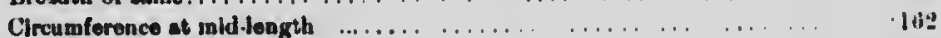

Brendth of expended distal end. ....... . . . . . . 0:17

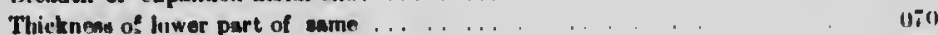

Thicknes of upper part of same ..... . . . . . .

Thicknews of proximul expansion nt cerntre ... . . . . . .

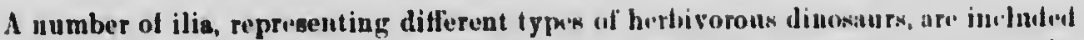
in the collections. In fig. 23, three of these are shuwu. The "ypur alu, $A$, is of the

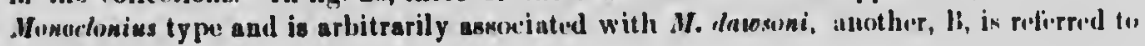




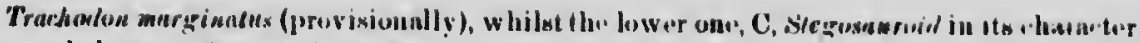
may belong to Nerrurphalus intws.
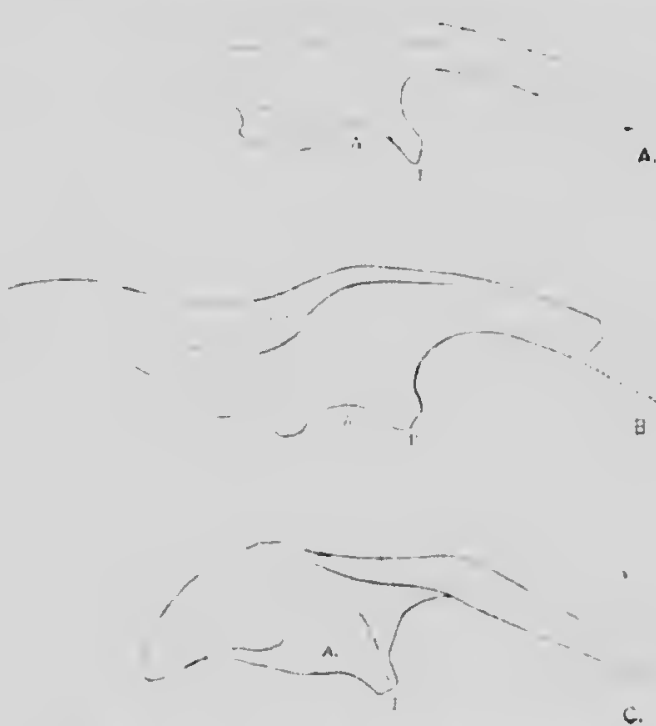

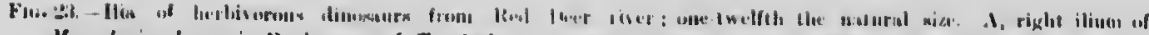

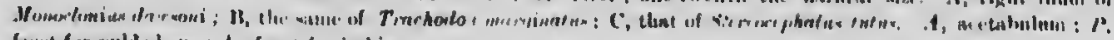

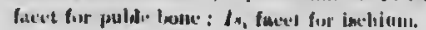

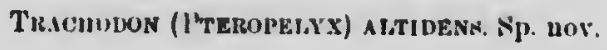

Pate IV, figs. 2, 3 und 4.

I loft maxilla, with the toreth proservind, reveals a hitherto undeseriber sperejes of Trucholun. Tl, tenth arre distinctly unrow in propertion to their length and are leanti-

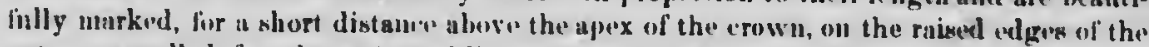
outer "namelled face by a fiew, obliquely plinerl, trankversely elongated emboksmente, which dererase in size gralually, from the apex of the tooth upward until they bereme"

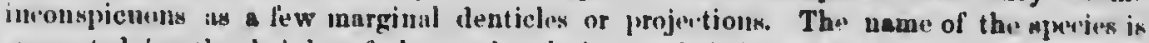

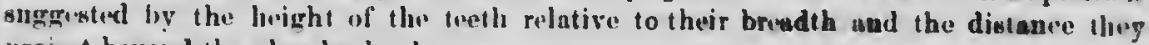
project heyond the ulvolar lorelir.

The maxilla iudiontos an animal of tompuratively sinall wizo and slender proportions. Thre" rows of teeth, more generally two, wre in use in the grindiux nurfuce of th" sane time, with at least two or three surios of sncessional teeth following, to replare those in use from the inside, the stunps of the old terth falling ont on the outside of the jaw.

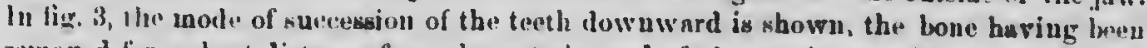
remosed for a short distauce from the anterior end of the specimen. About oue-lifth of 
the maxilla is unissing anteriorly, as well as it consideruble part of the suproing loorder

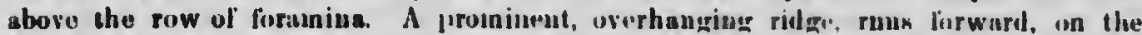
onter side, from the powterior end, forming the onter and lower borter of the lisen lor the

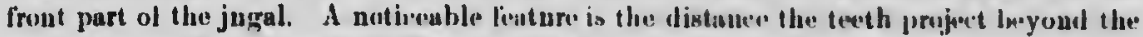
borders of the al reolar walls. Four nenro-vasenlar lormnina are conspir-nous in the outer wall in frout of the ridge just mentioned. The enamellyl surface of the erown of ench tooth bears a strong inedian ecarination. The teeth lirus which the apires have berll removed by use are gnite suooth and do not show the characteristic horder inarkings

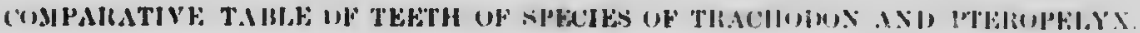

Prochedune inerobalie, levily.

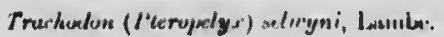

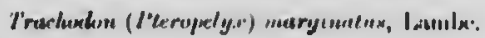

I'teropelyr gralligex, Cisjes.

Truchenkm (I'bropelyr) alliknx, Lambe.

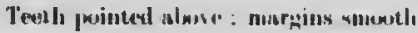

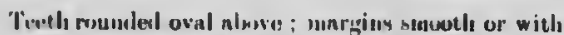
tlie fuinteat indientions of oblipue trausvorse stria. ling. :- plaw III.

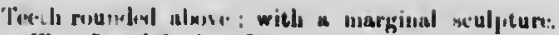
Pigs. 5 and 6, plate IV.

Teeth ruonded alase, with a Iximler siulpture. Fige. 7, plate IV.

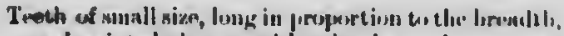

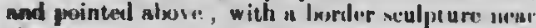
the apex: Fin. 1, jlate IV'. spercice "il re beantigi's of thi' ansinents, y beroun: nin'viss ix ne'c thory

portiouk. the sanne - thow in the juw. ing lneen e-lifth of 


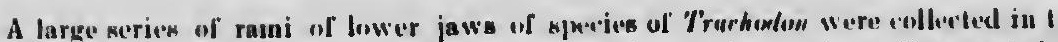

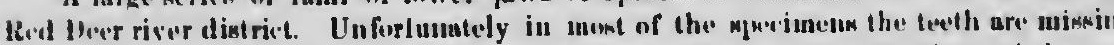

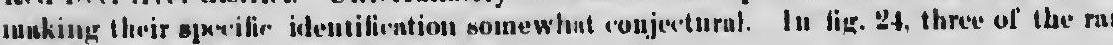
are ligured to show siza and form.
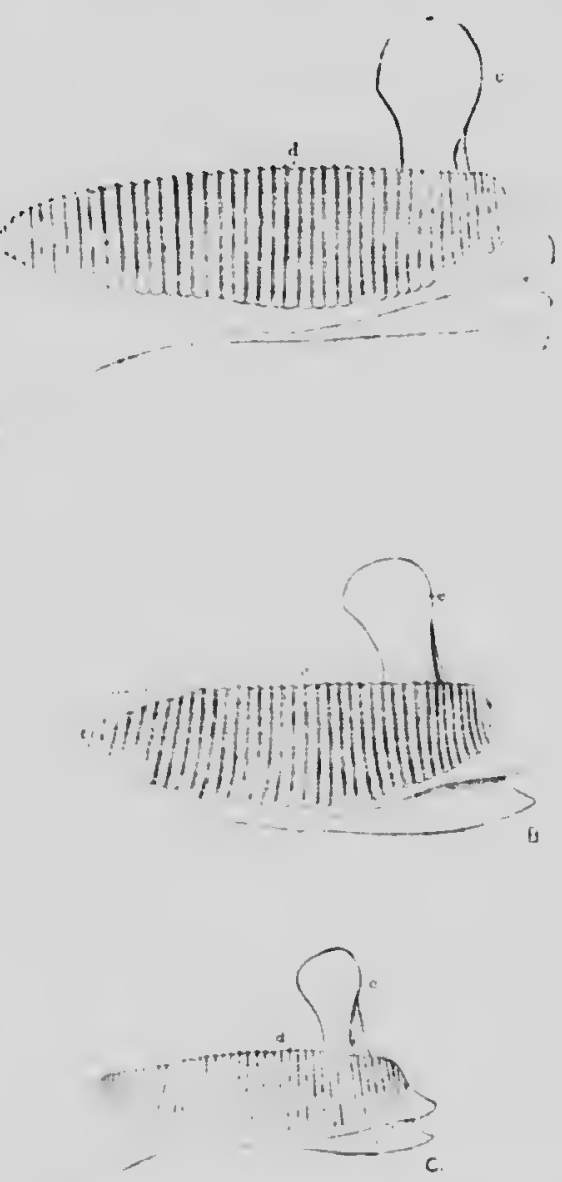

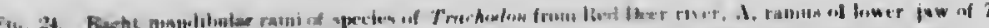

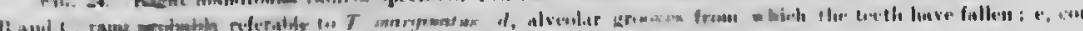

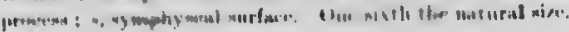


"reted in tho aro iniasiug, of' the rami

\section{M.MMALA. MULTITULFACULATA.}

\section{I'LAIIIATILACII)AS}

P'thand's Cop'.

I'TILOHU: IrRIM.EVU. Sip. nov.

Platı XV, fign. 13 and 1\%.

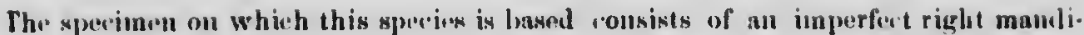
loular ranus in which the fourth promoliar and tloc lirst nolar ase preserved. "The fracture

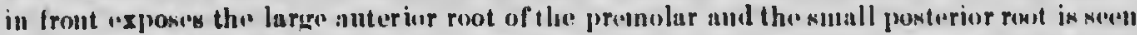
from the sutor side. The lower lront lisrder of tlis: arown w' the promolar is slightly

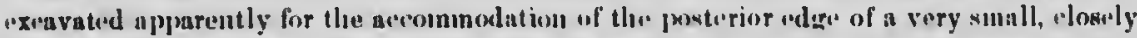

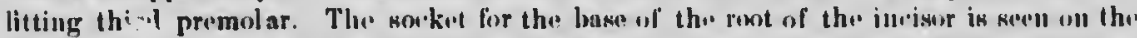

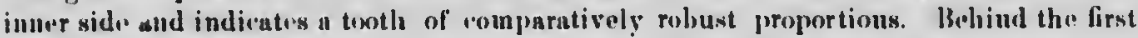

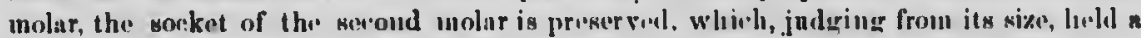
tooll rousidorably sanaller than the first unolar.

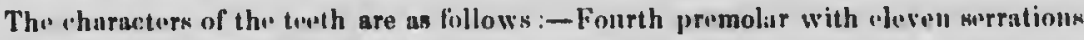

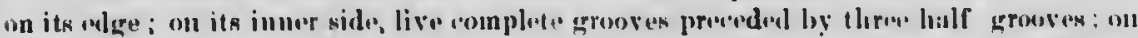

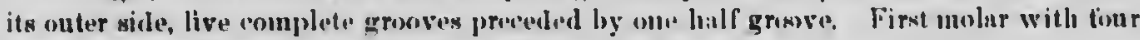

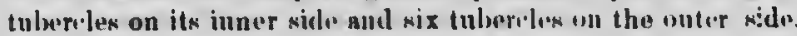

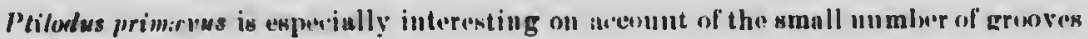
oll the large cutting fourth promolar (appren'hing the goums Menisrowssus in this renpert) and the slightly backwarl "urv" ol" the tulsorelok on the onter sid" ol the lirat molar, also suggestivo of Meniscoinsus.

In the figurew of the type of the spereins, the towtl wre whow an thry appenr in the

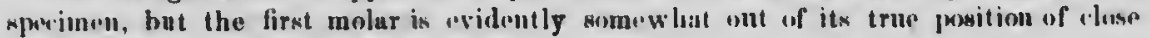
proximity to the fourth premolar.

Bally Riror keries, lled lear rivor, 1901.

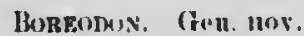

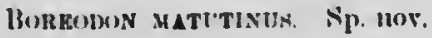

Phate XV., fig. 15.

This carly iypo of mammal is represented by a wingle tooth, a promolar, having two. alightly dirergent roots. The arown is in the firm of in latorally compersenl cone, sounewhat romuled ahove, angular in front, evenly roundinl belind, with a well defined.

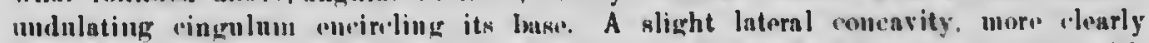

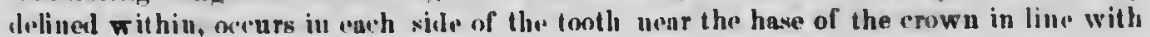


the cleft betwern the mols. The cingulum in angular and prominent at eithor on beroming roundod and broader on the vides. The crown in ronniderably worn on t iutuer xido of its apmex. One root only remaine and it is imporfert bulow.

Neramurements.

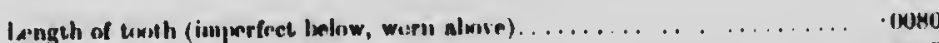

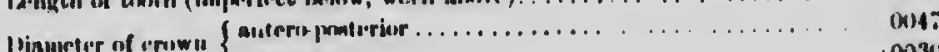

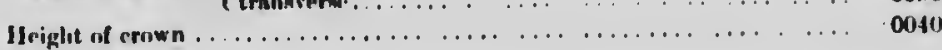

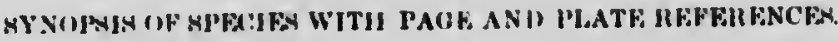

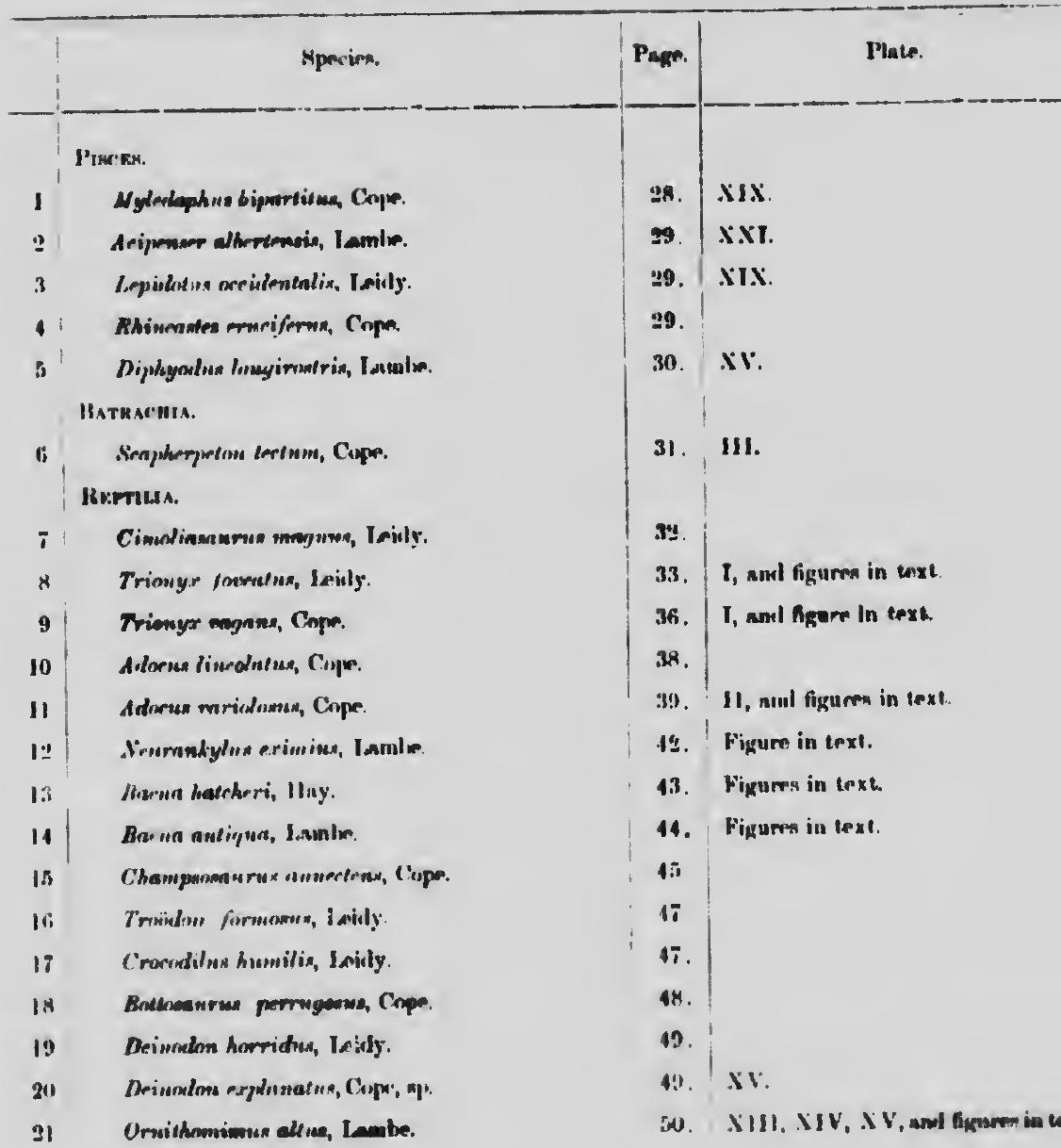



Plativi.

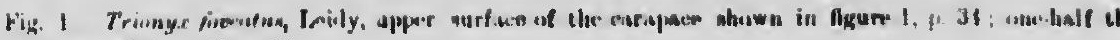
uretural size. Vage 33.

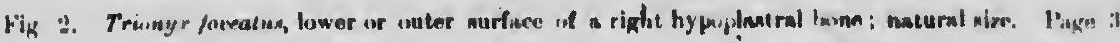

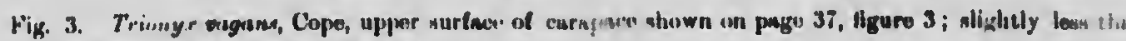
ine fuurth natural nixs. Pugge 36.

Fig. 1. Porttun of the ulper surfnes of the same cmrapese, uatural nize; wo show the sculpture. 

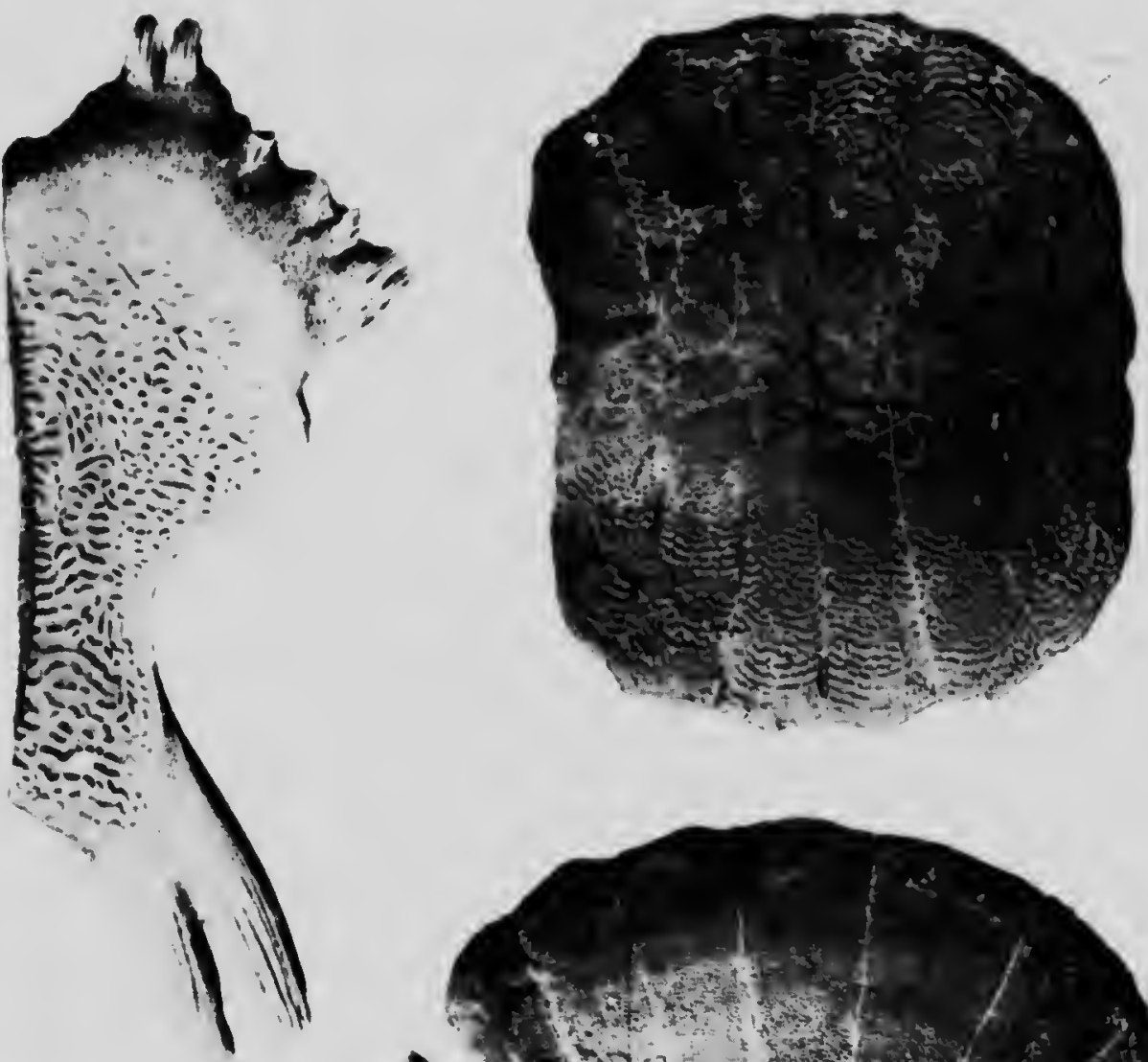

er. lasm: 15.

my lews than
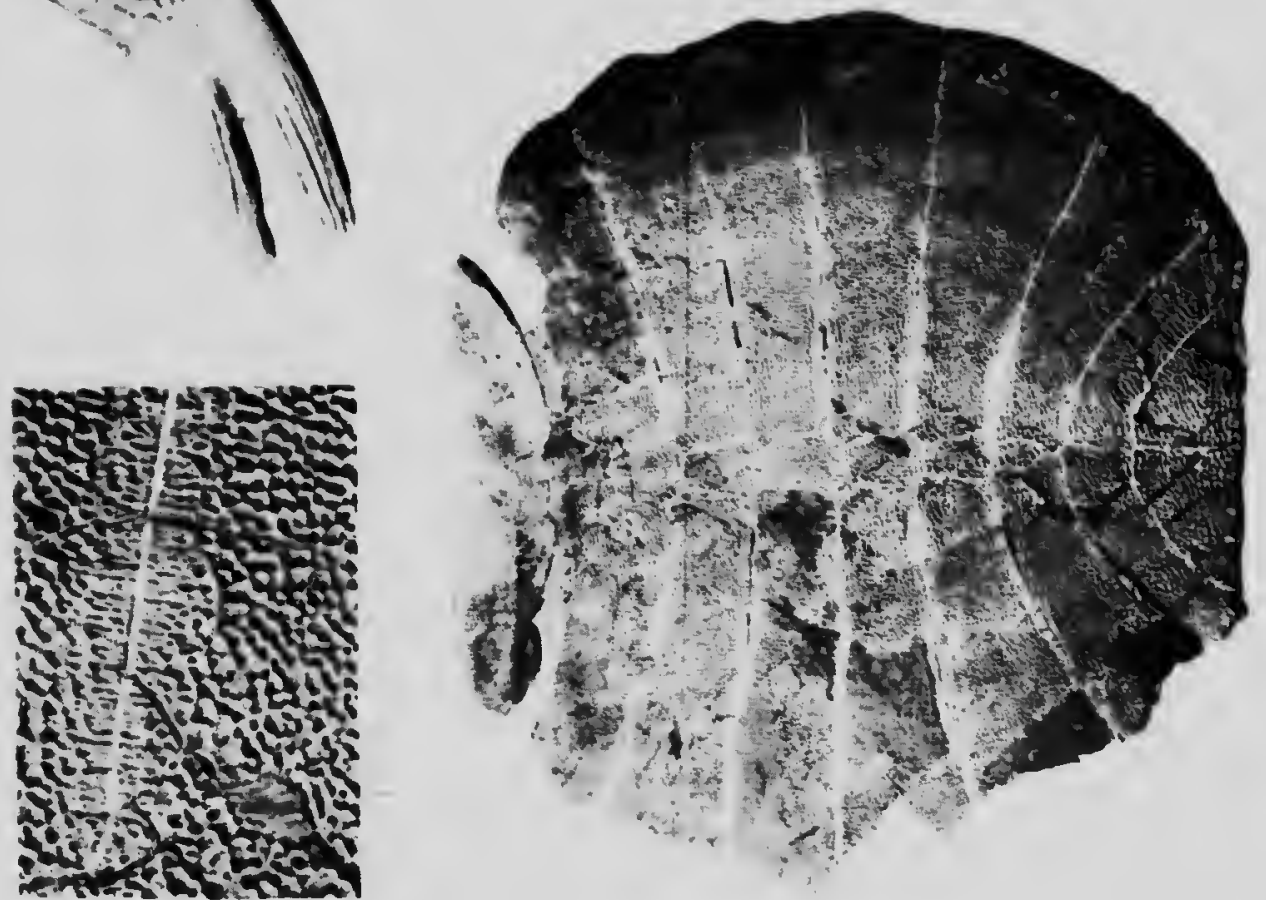


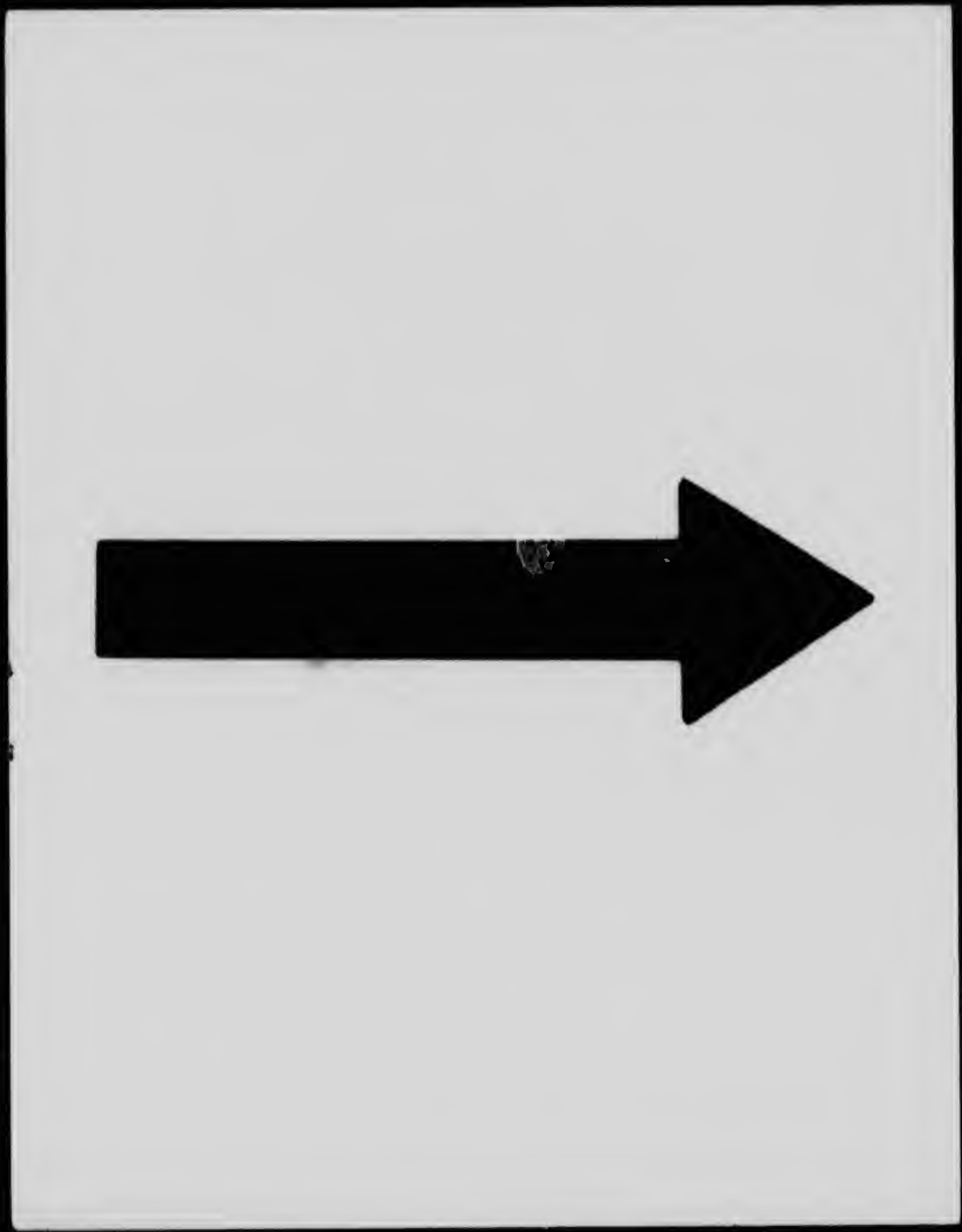




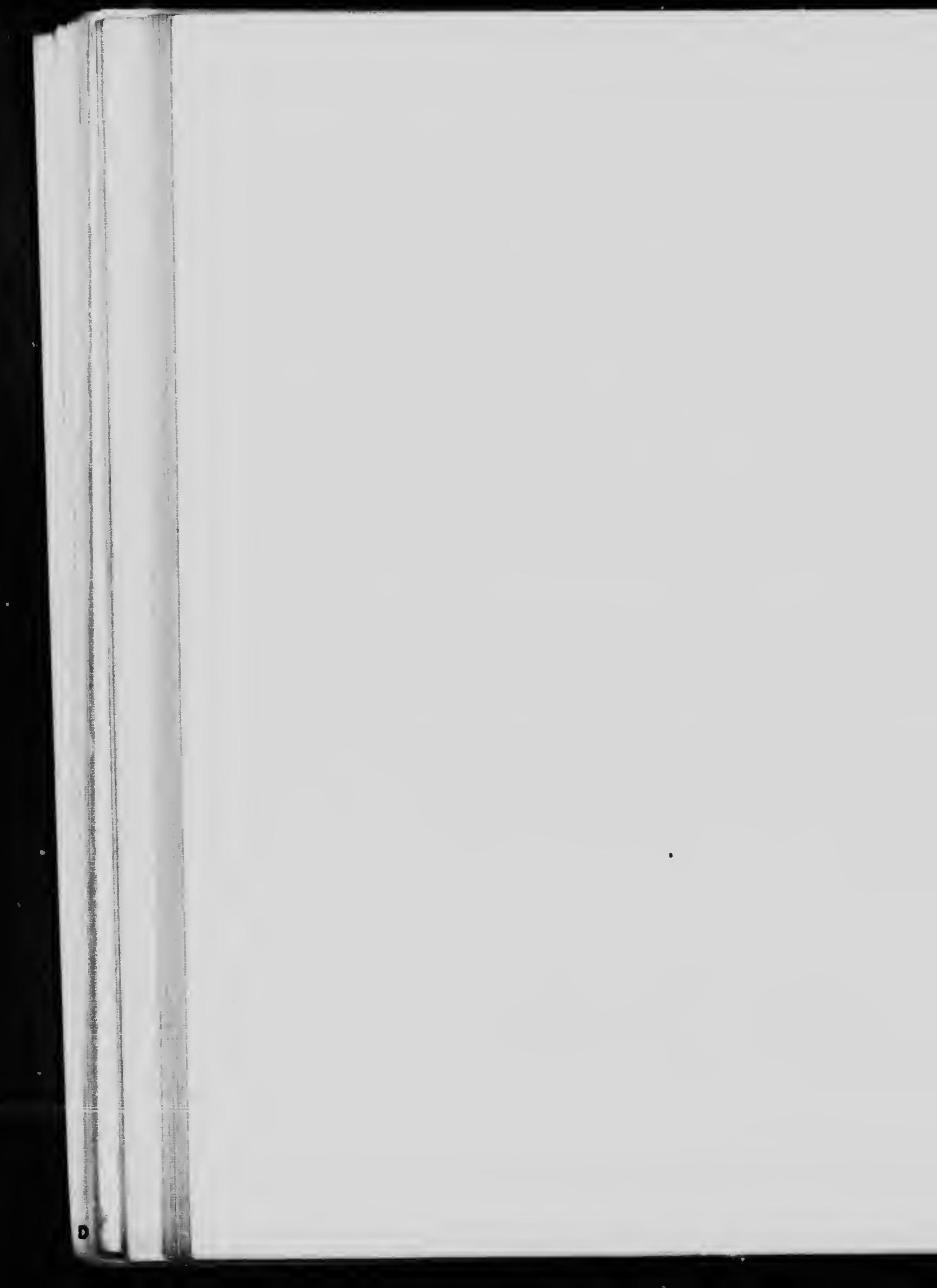



PLATE II.

Adocus crarioloous, Cope. (sp.)

Vig. I. Plastron, lower or outer surface of sprecimen represented in tigures 4 and 5 , page 39 ; one-thi natural size. Page 39.

Fig. 2. The same, upper or inner surface.

Fig. 3. The lower surface at the snterior end of the sawe plastrun, natural size; to show the charact of the sculpture. 
İIR.ITA.

Contributions to Canadian Pal.kuntoloay, Volume III. (Quarto), Part 11.

Page 7, 18th line--The original description of the Judith River beds by Meek and Hayden* is as follows: "They appenr, as near as conld be ascertained, to orcupy a local basin in a series of marine deposits, consisting of beds of sandstone and impnre liruite, which we have regarded provisionally as of the are of No. 1 of onr ganeral section Lower down the Missouri, near the mouth of Little Rocky Mountain creek, this last-mentioned series of rocks apon which the fresh-water deposits repose at the mouth of the Judith is clearly seen to pass beneath No.t (the I'ierre shales) of the general section."

This original description leaves the question, whether the typiral Judith River beds are above or below the Fort Pierre, undetermined. It appears that the latter authorities cited on pp. 7-8 may have confused the typical Judith River beds with the Laramie. Mr. J. B. Hatcher believes there is little doubt that the typical Judith River underlies the Fort Pierre. He observes: "I remember, howerer, to have noticed some 800 or 400 feet of shales very similar to the Pierre, overlying the Judith River beds along the old Fort Benton and Cow Island trail between the Bear Paw Momntains and Cuw Creek, and I have little donbt but that these are the representatives of the Pierre shales in this region." If this observation be confirmed, the typical Judith River beds would be placed in the Mid-Cretaceons, or nearly contemporaneous with the Belly River as held by Dr. G. M. Dawsos.

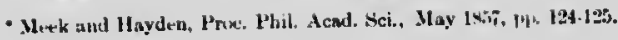




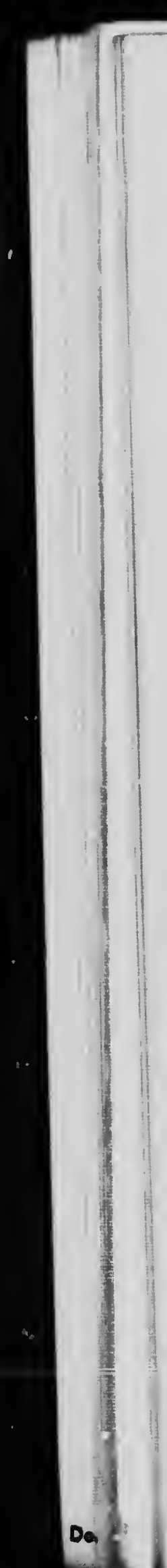




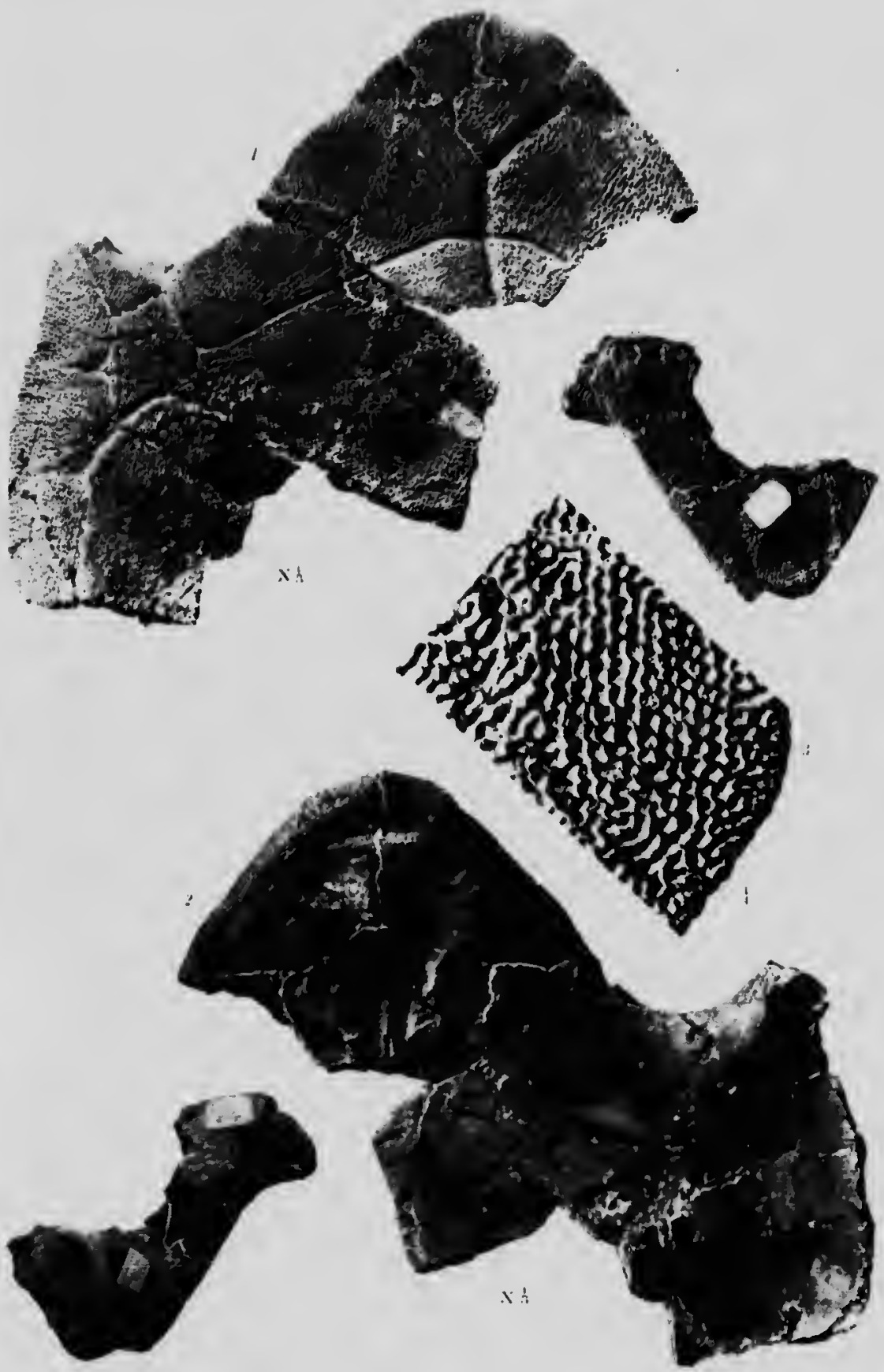




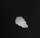



Pl.ate. III.

Fig. 1. Trockodinn ('lempalyr) marginatue, lamle, inner wide of left ranus of lower jnw, show teeth; one-half the naturai aizn. Paye 73.

e, coronoid proocan; a, symphywai surface; b, inner wail of riontai chamber ; $e$ mal groove; $\alpha$, foramon.

Vig. 2. Trachodon (Ptoropolyx) wiwyni, Iamhe, Inner nurfece of tenth of lower jav, wh show wur natural nizo. Page 69.

Fig. 3. Orinding worluce of weth of sanuf apecimon; naturai size.

Fig. 4. Scapherpeton ketum, Cope, dornal vertelura, frore the left side; twice wen maturai nize.

Fig. 5. View from tho tronth same specimen.

Fig. 6. Scapherpolon tectum, atian, front view; twice the natural nizo.

Fig. 7. The rame, viewed from bohind.

Fig. 8. The acme, side view trom the left.

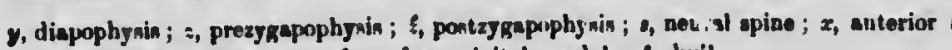
cup ; $u$, neurai canal; , fecet for occipital condyle of skuil. 
jaw, showing the er ; e, mencliluular w ahnw surcemion sural size. Pege 31. anterior articurnl

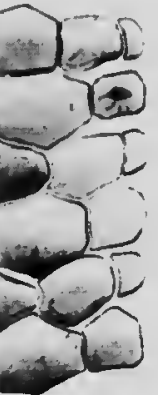
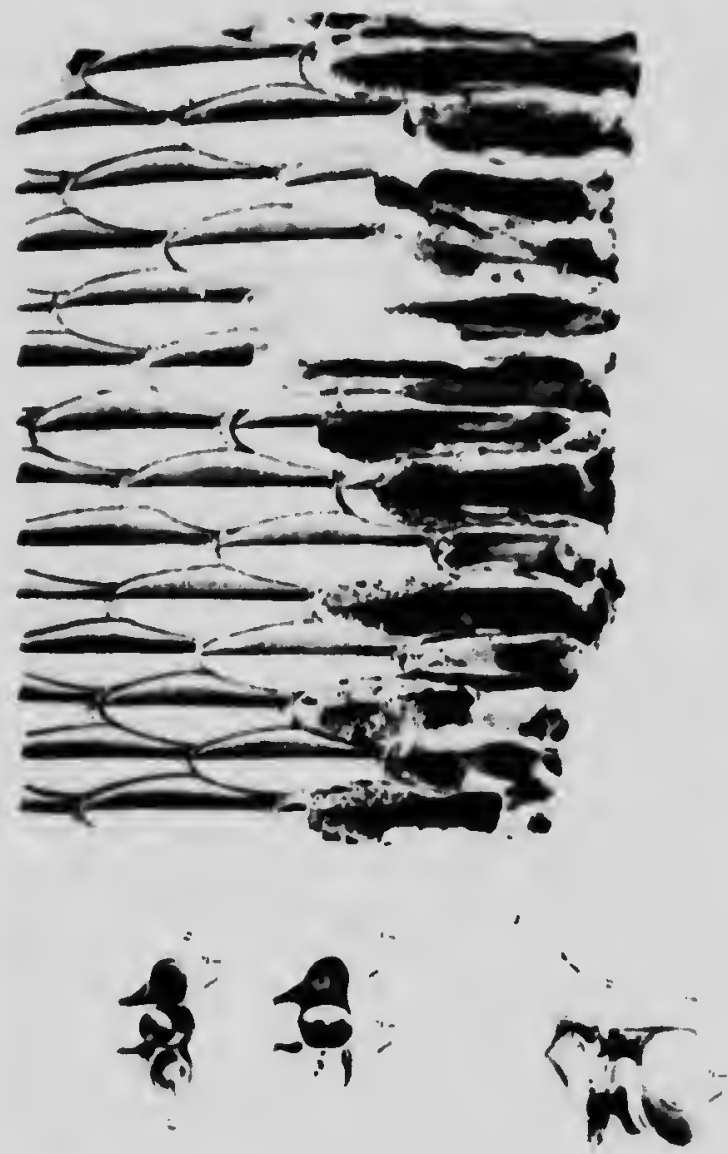

0

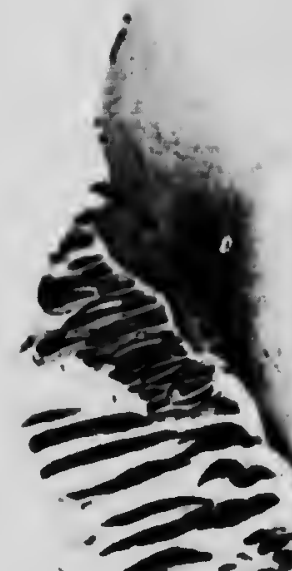

s?
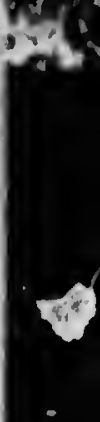


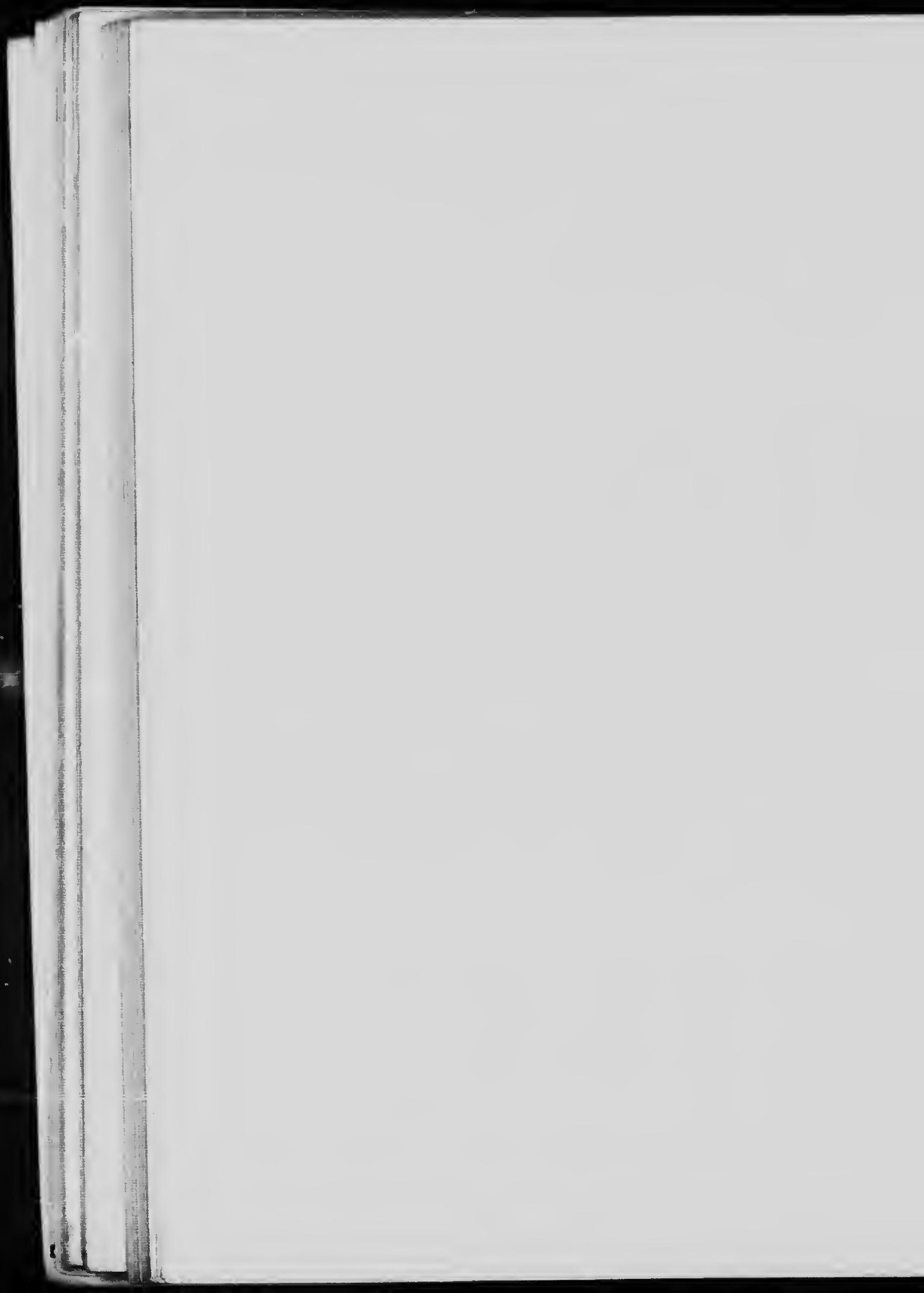



PLATE IV.

Fig. 1. Trarhodon (Pteropelyx) marginatur, Lambe, outer side of tlie same mandihular ramus figured on plate III : one halt the natural size. Page 73.

Fig. 2. Truchodon (Pteropelyx) altidens, Lambe, outer side view of left maxilla, one-half natural size. Tho speciman was drawn upside down so as to have a better light on the teeth. Page 76.

Fig. 3. Inner view of the same specinen, with part of the inner wall removed to show successional teeth; one-half naturnl size.

Fig. 4. Two teeth trom the same specimen, showing the characteristic horler sculpture, with the cmwn of the worn tooth restored, in dotted outline, to show the propurtion of length to breadth; twice the natural size.

Fig. 5. Trachodon (l'teropely.r) marginalus, Iamle, outer view of apical part of , mwn of tonth from the maxilla represented on plate $V$, for comparison with fig. 4 ; twice the natural sizc. Pago 74 .

Fig. 6. Trachodon (Pleropely.r) marginatun, crown of one of the teeth of the ramus shown in fig. 1 of this plate and fig. 1 of the preceding plate; twice the natural size. Page 73.

Fig. 7. Pteropelyr grallipes, Cope, crown of tooth of lower jaw, th show horcler seulpture: twice the natural size. Introducod for comparison. Page $i 7$.

$f$, grinding surface of teeth; $a$, tacet fur jugal. 
Ins figured

atural size

\section{6.}

innal teeth ;

h the crown dth ; twice

th from the o 74.

in fig. 1 of ; twice the

$\geq$
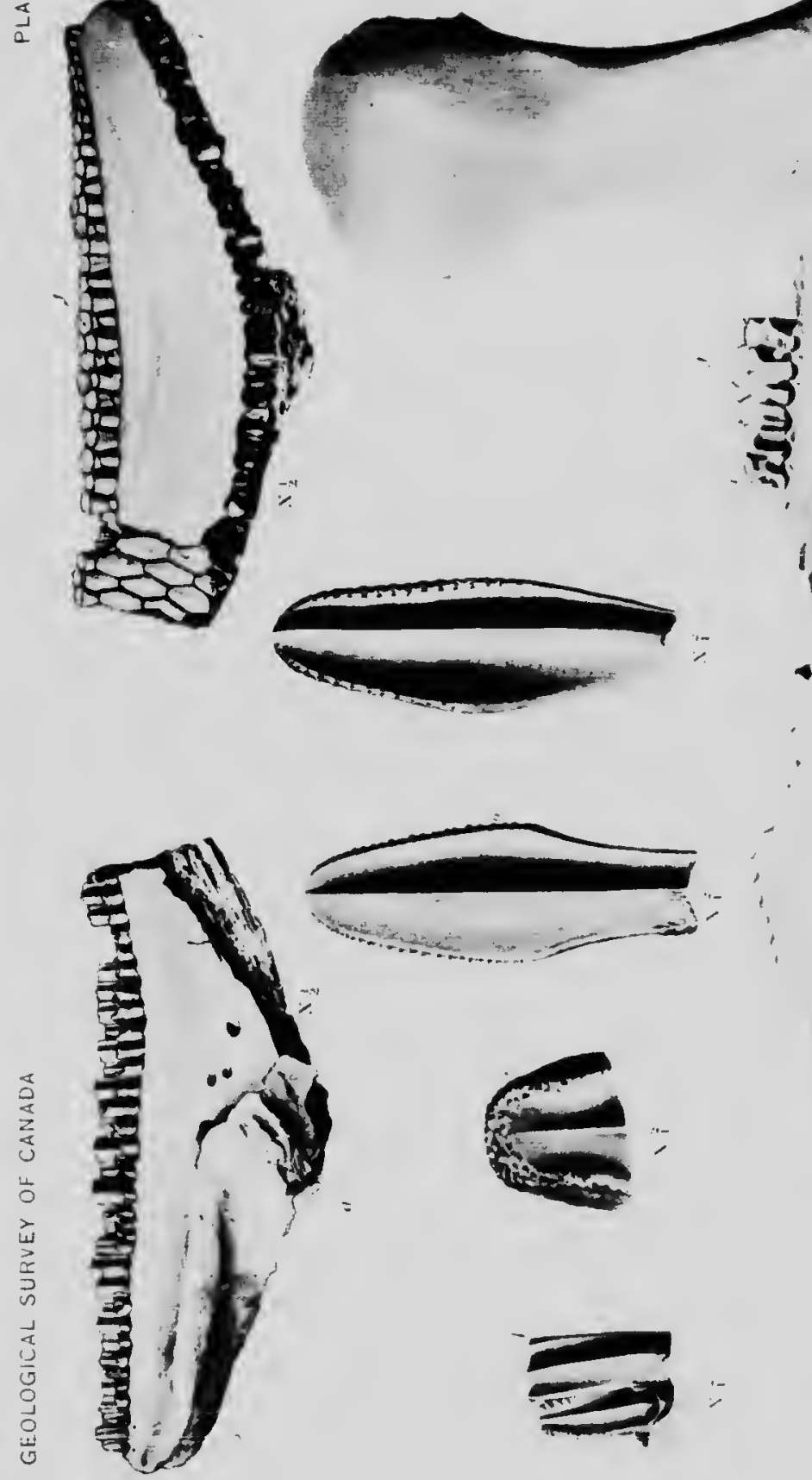

I
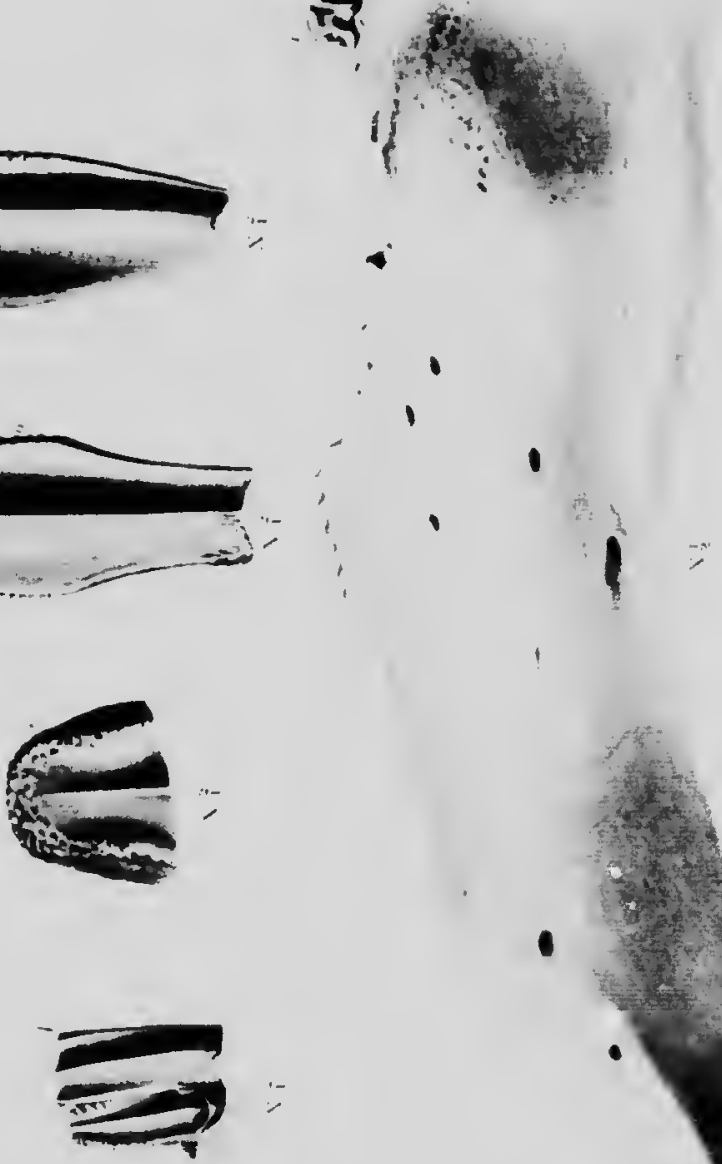

0

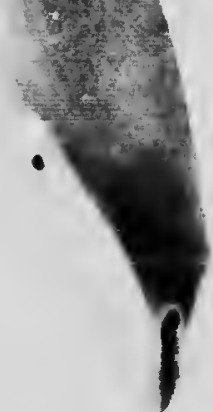




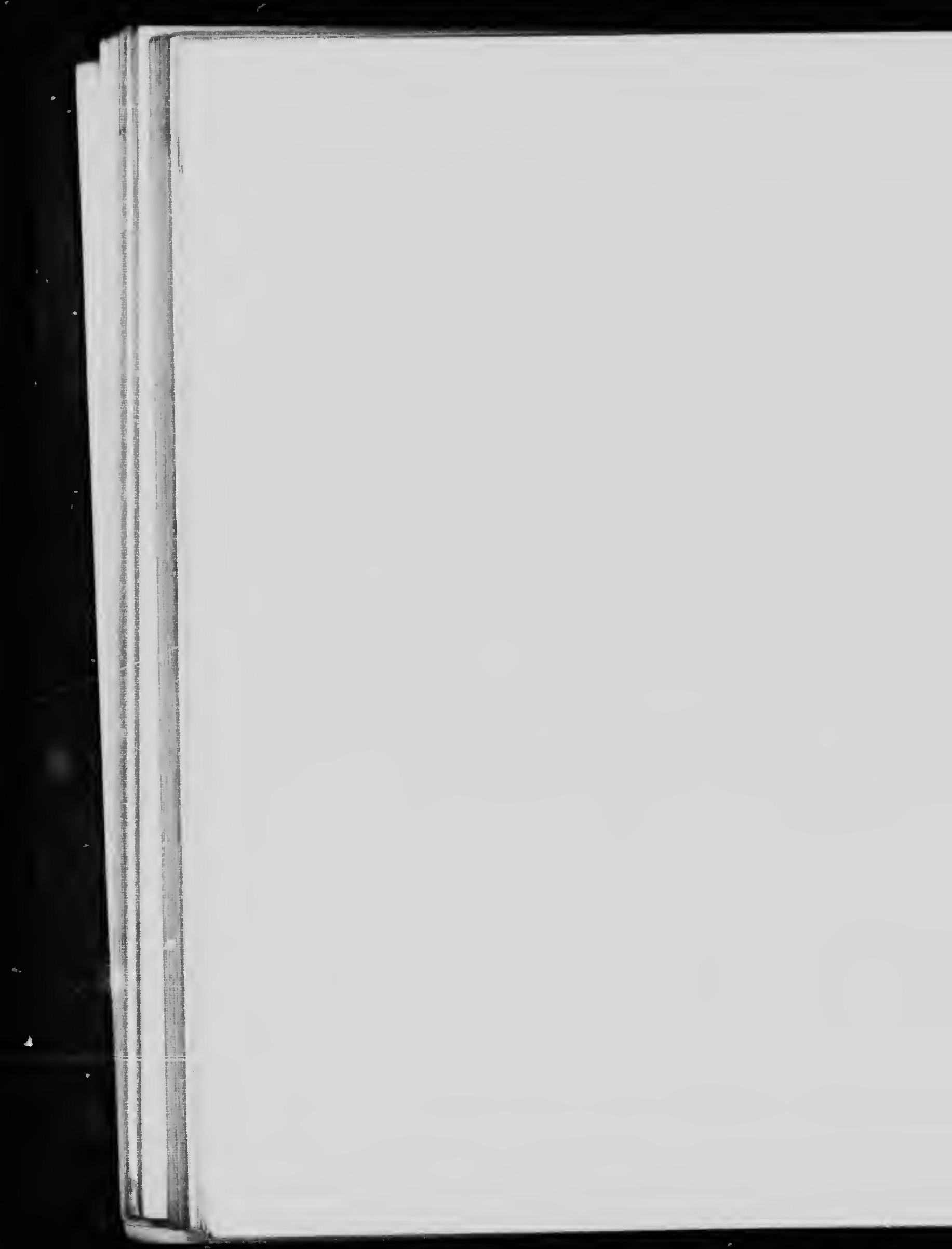


PLATE V. 
PLATL V.

Fig. 1. Trachodon ("teropely.c) murginutun, Lausbe, right unaxillary bone, external viuw ; redue half. Page 74.

Fig. 2. The sanne, internal view.

Fig. 3. Th. sant, superior view.

$a$, facet for jugal ; $b$, facot for palatiuc. 


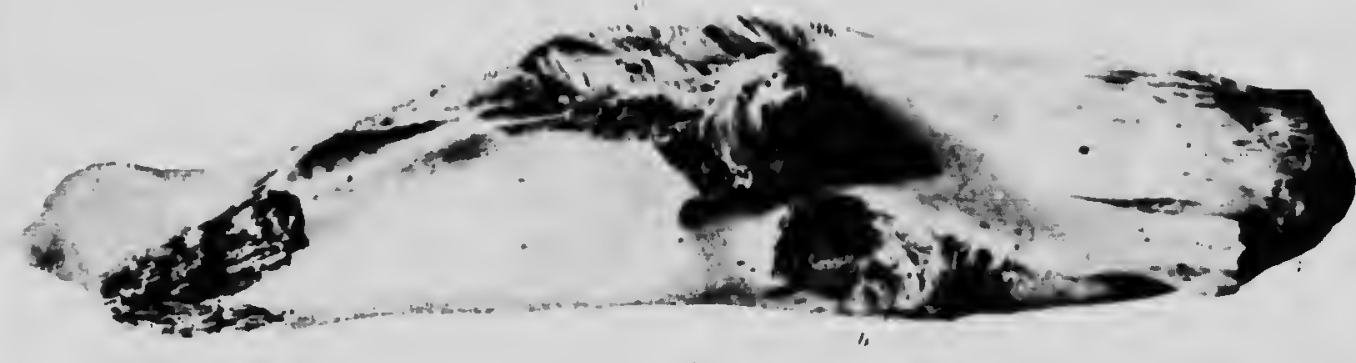

$1 !$

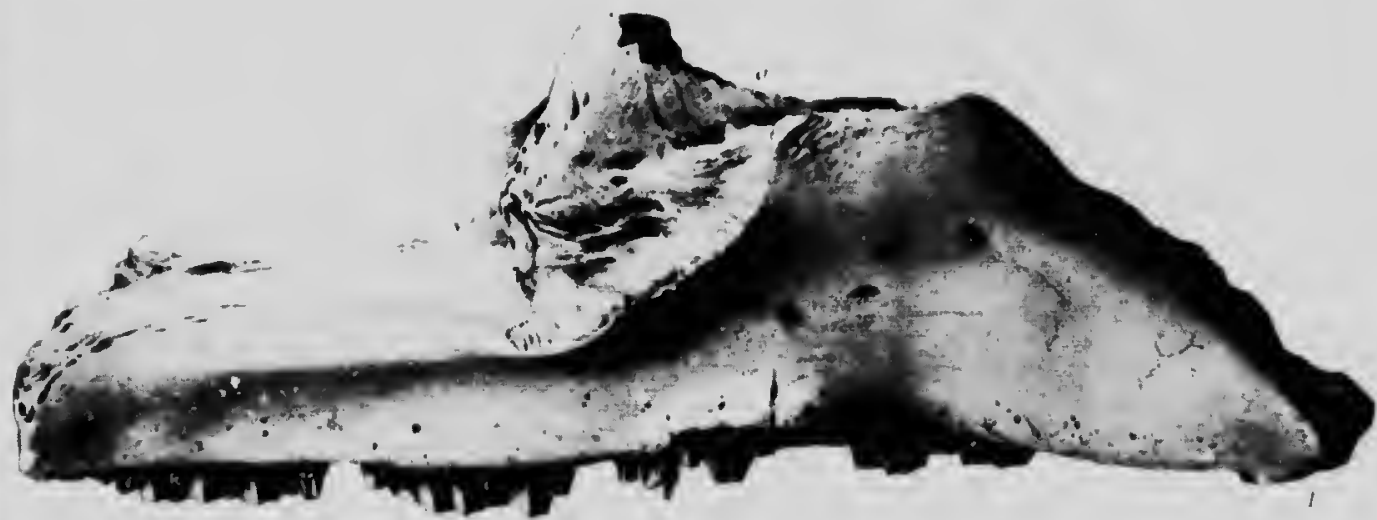

X!

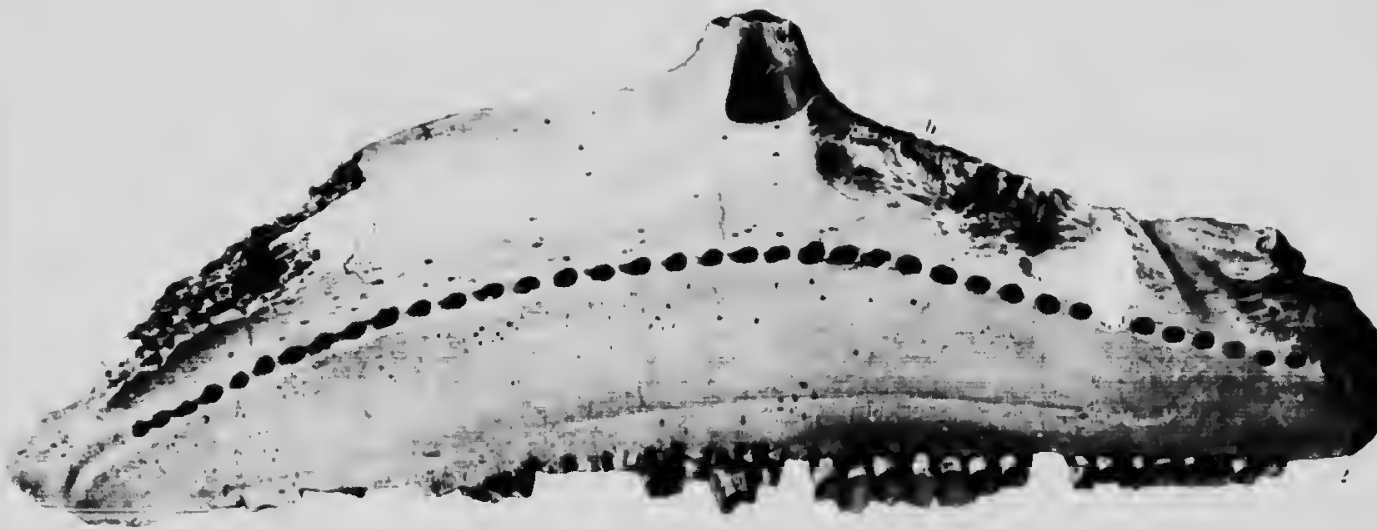

I: 


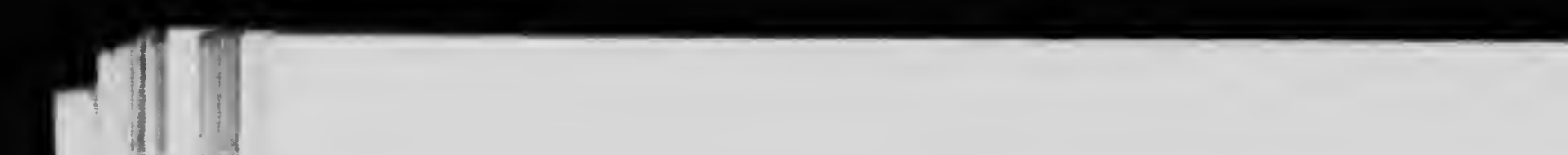




$$
\text { PLATE VI. }
$$




\section{Hostr: VI.}

Fig. 1. Trachedun (I'teropelyx) maryinatu, Lambe, left humerus, viowed ubliquely frow inuer fro one third uatural wize. Puge 71

Kig. 2. The sane, frutu unler rear.

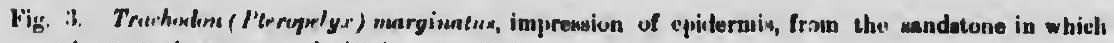
alsove speciuen was eculuethled; natural vize.

r, ralial crust; $h$, heal ; i, inner tuberumity ; u, outer tuberusity ; $c$, unter condyle. 
GEOLOGICAL SUR EV OF SANADA

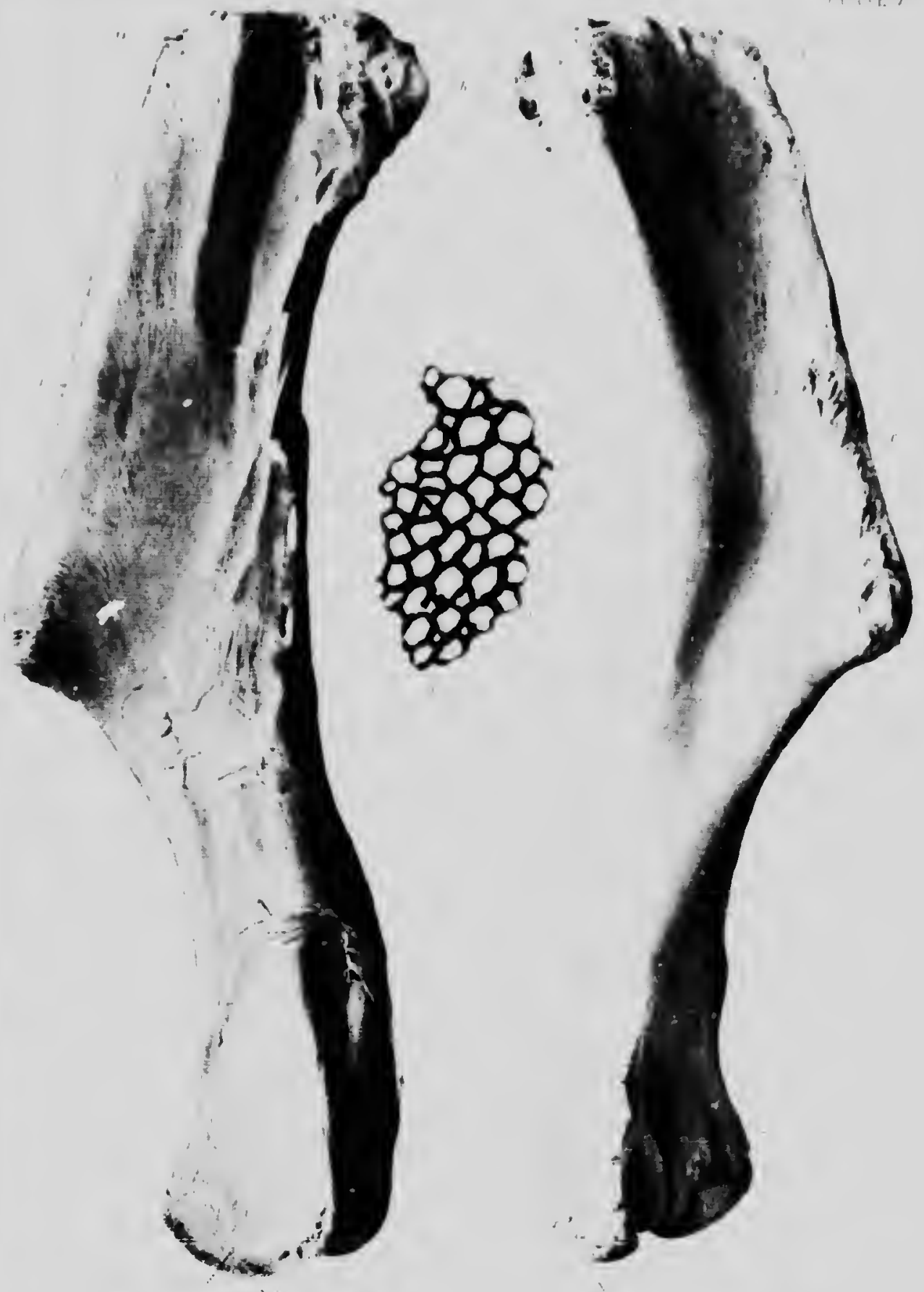




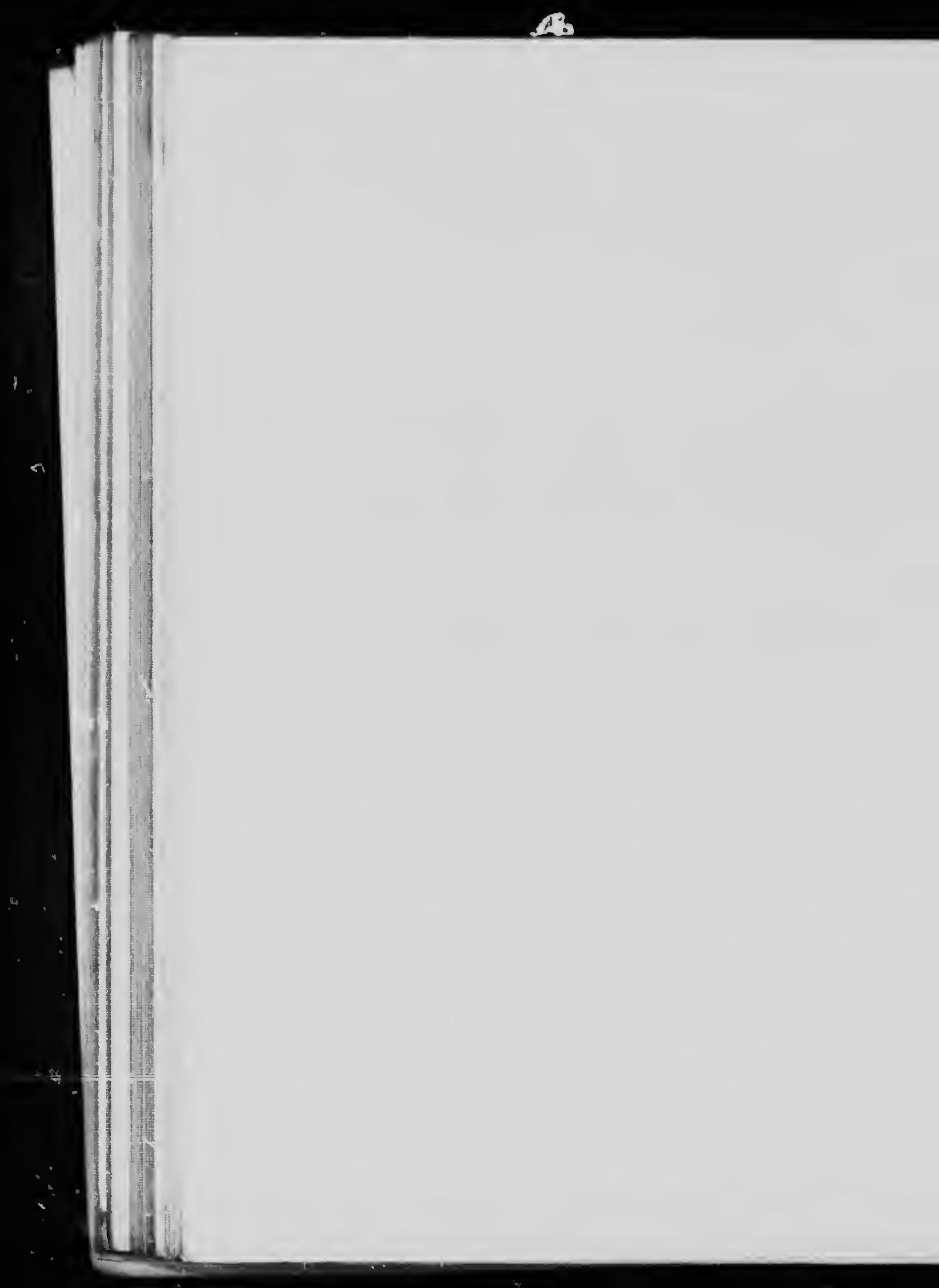



PI.ATE: VIJ.

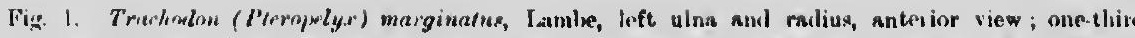

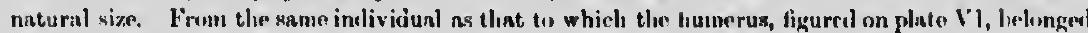
Prge 72.

Fig. 2. The sanie, prosterior view.

$n$, ulna ; r, rulins : o, olecrannn proeress. 
GEOLOGICAL SURVEY OF CANADA

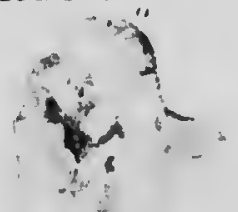

; one third i, lirliongerd.

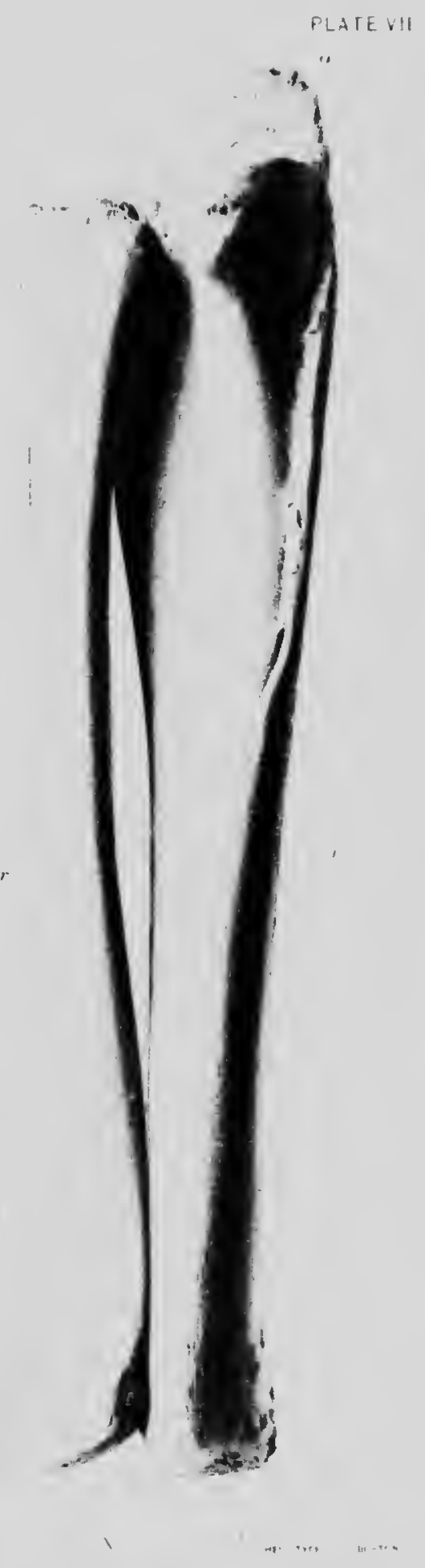




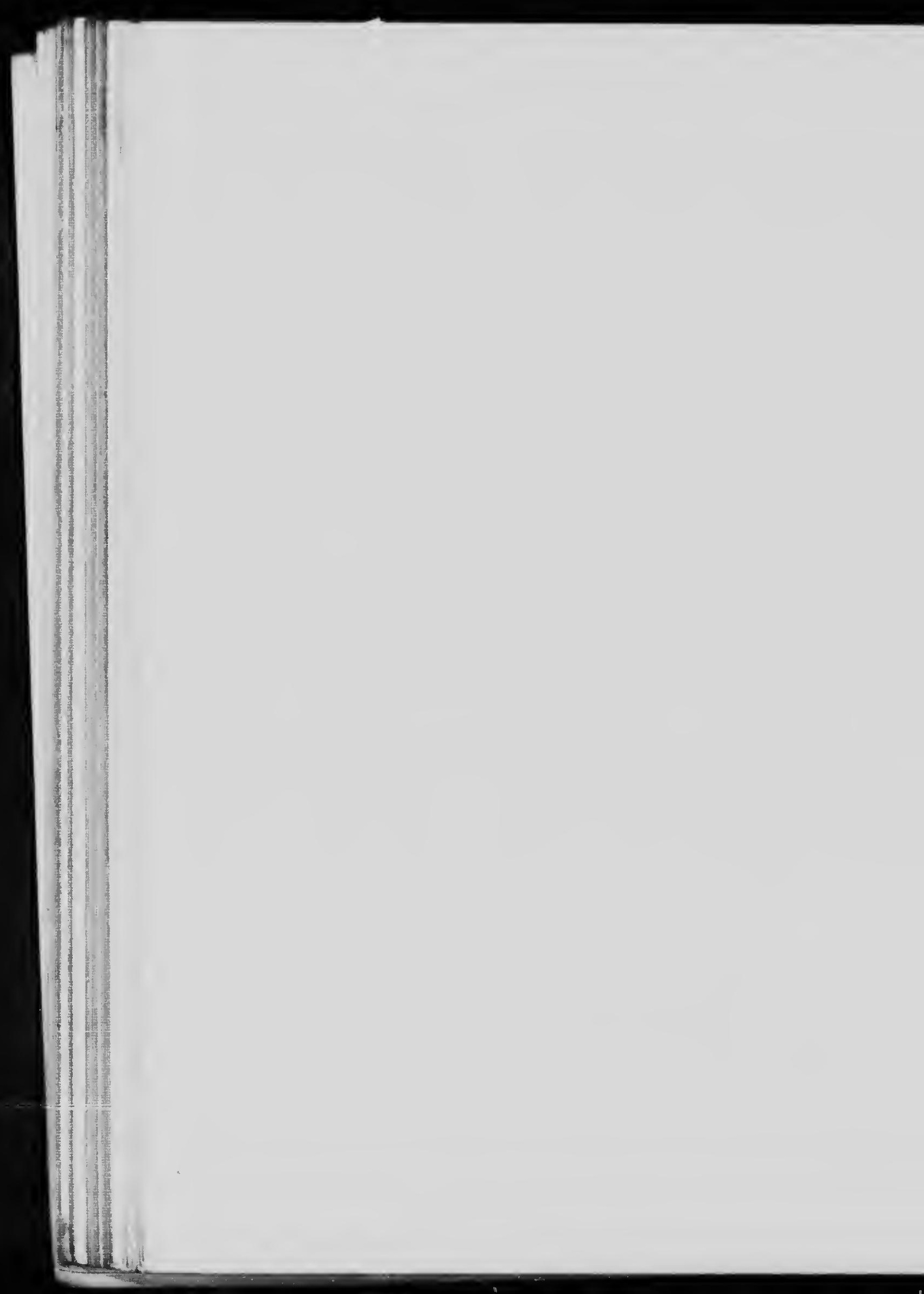


PLATE VIIT.

13 
PLATE VIII.

Fig. 1. Trashorkn (Iteropely. maryinatus, Ismle, right follur, anterine virw; one-fifth thon size. (Provisionslly ausociated with 7 . marginufus). Page 72.

Fig. 2. The same, internal view.

Fig. 3. The same, posterior view.

$h$, head ; $t$, great trochanter ; $m$, third tmochanter : $c$, inner condlyle 

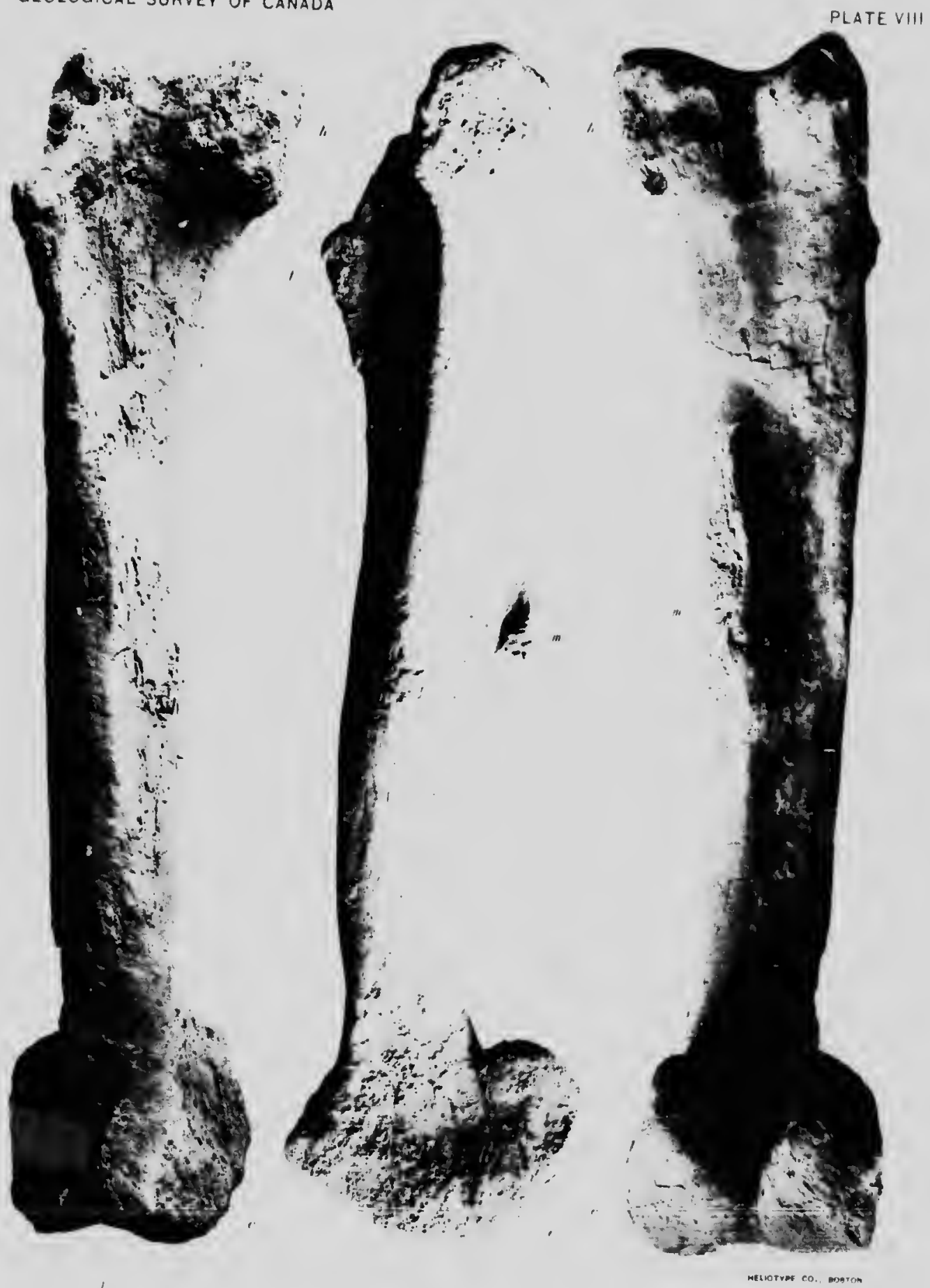


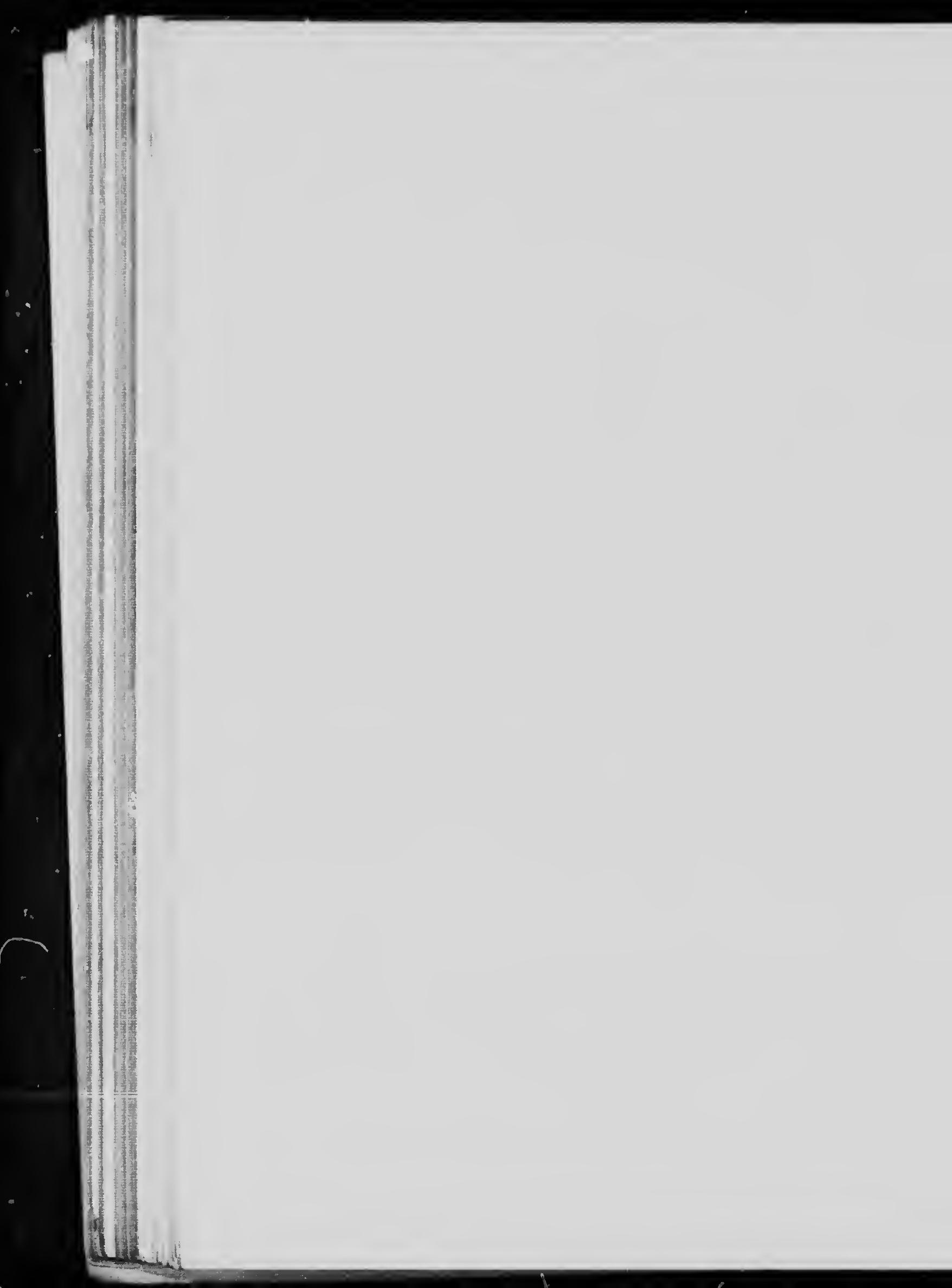


PLATE IX. 
ULATE IX

Fig. 1. Trachedon (Pteropely.r) marginatu, Ismbe, right tibit, externnl viow ; five twenty thirts the natural size. (Provisionally associated with $T$. murginutus). Page 73

Fig. 2. Another tibia of the snme species, posturior view ; similarly reluctd. (Provisionally ansociatuml with $T$. marginutus) 

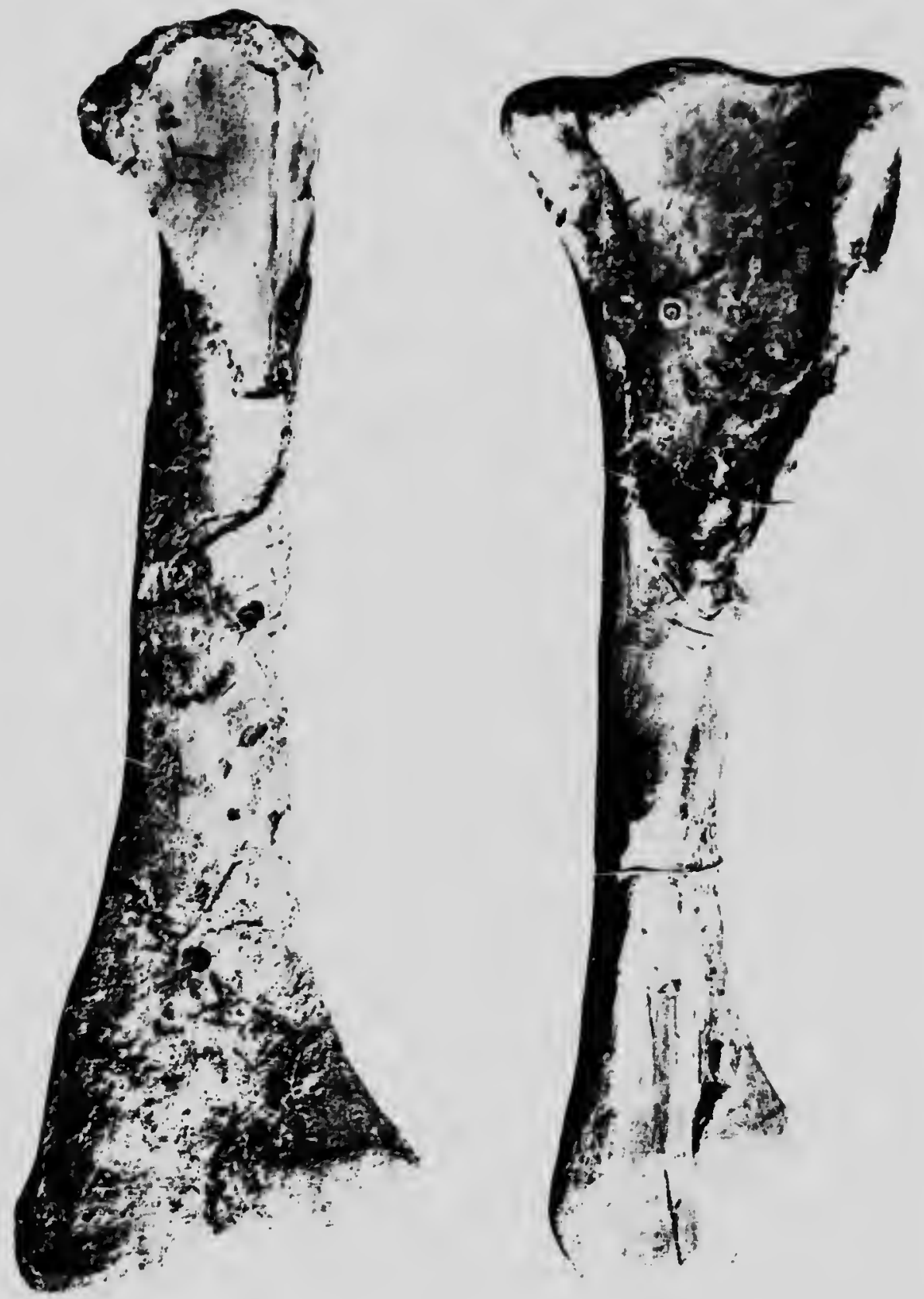


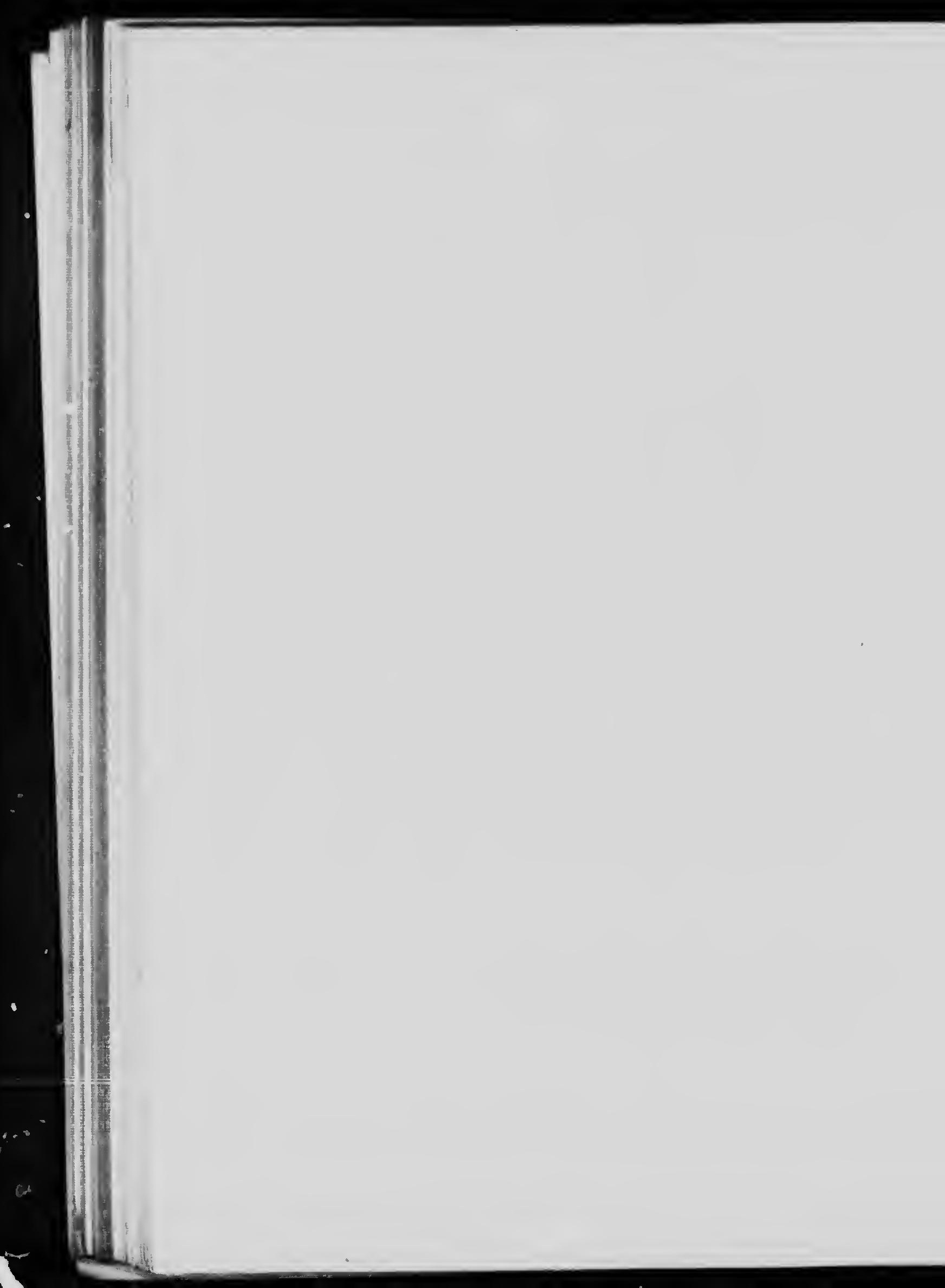



H.ATE $X$.

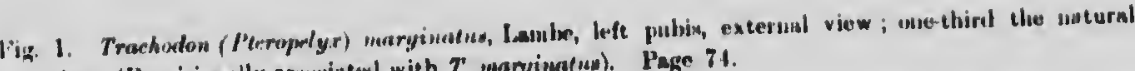
sixs. (Pruvisionally aumeintesl with 7 . maryimatus). Page 74.

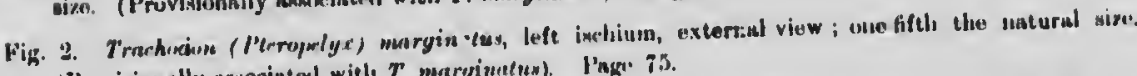

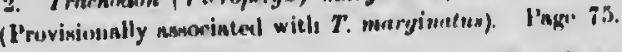

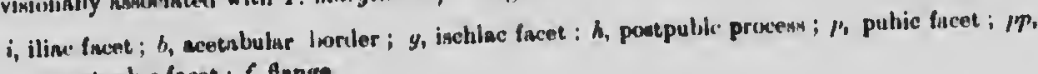
postpubic facet; $f$, Anngo. 


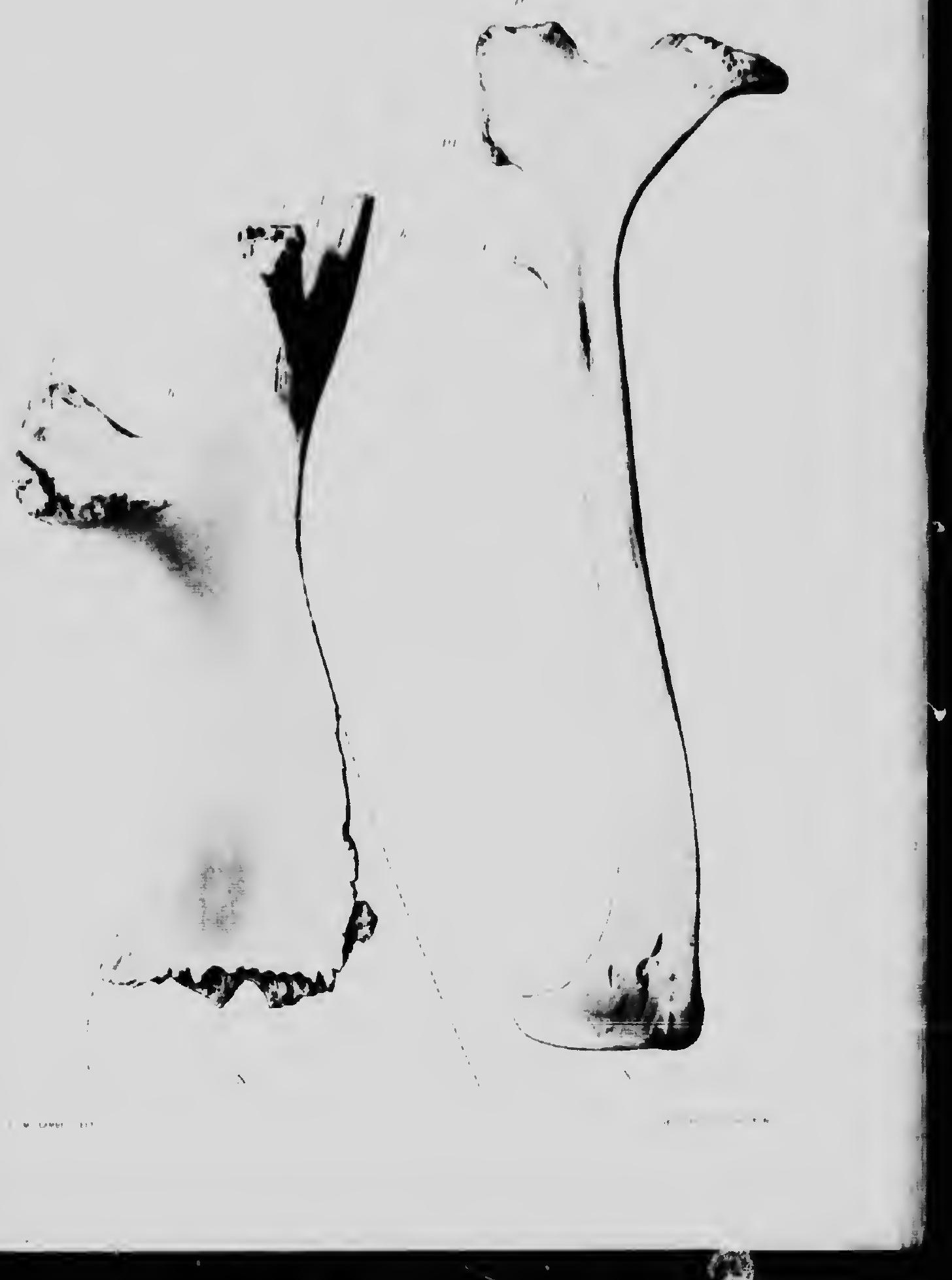




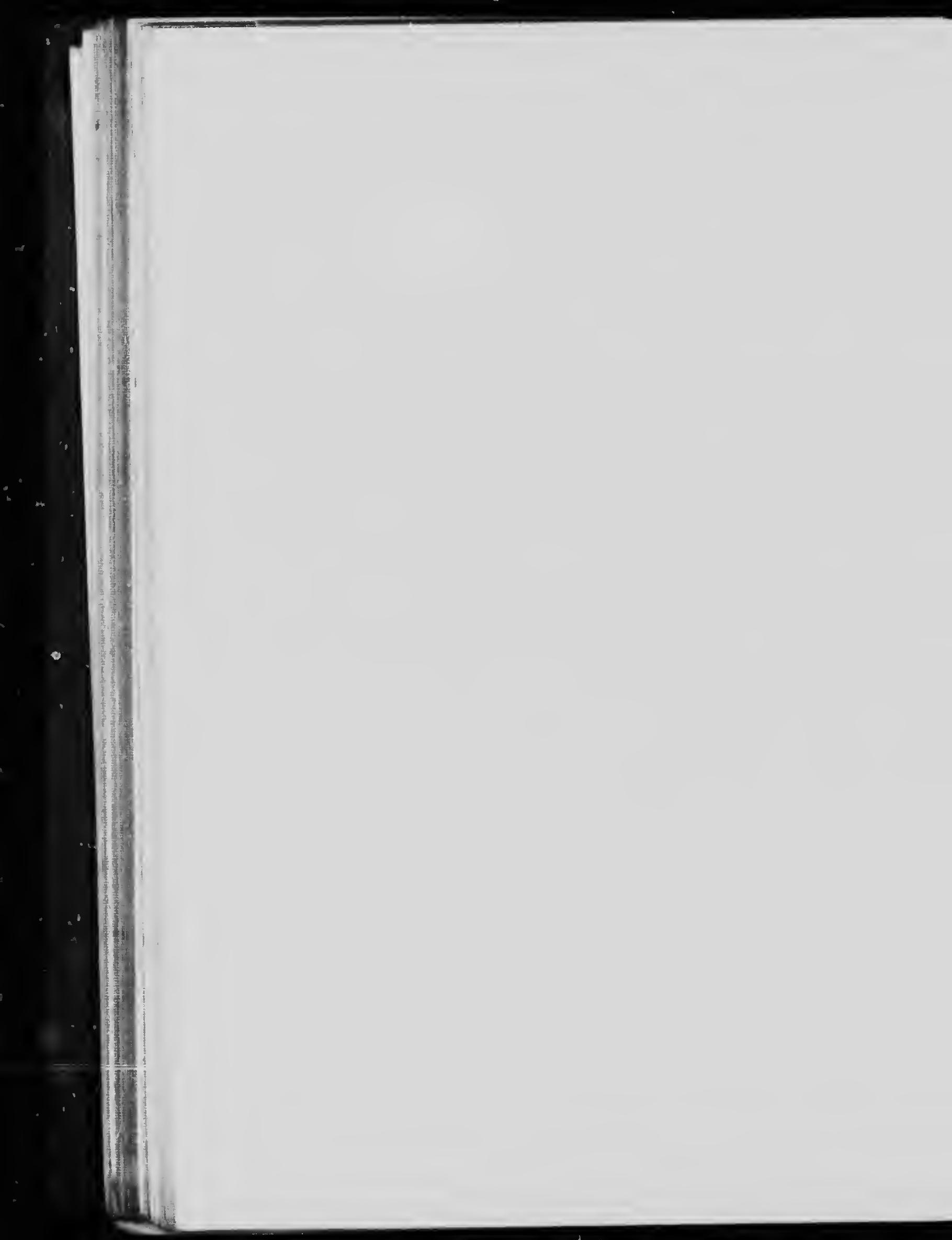






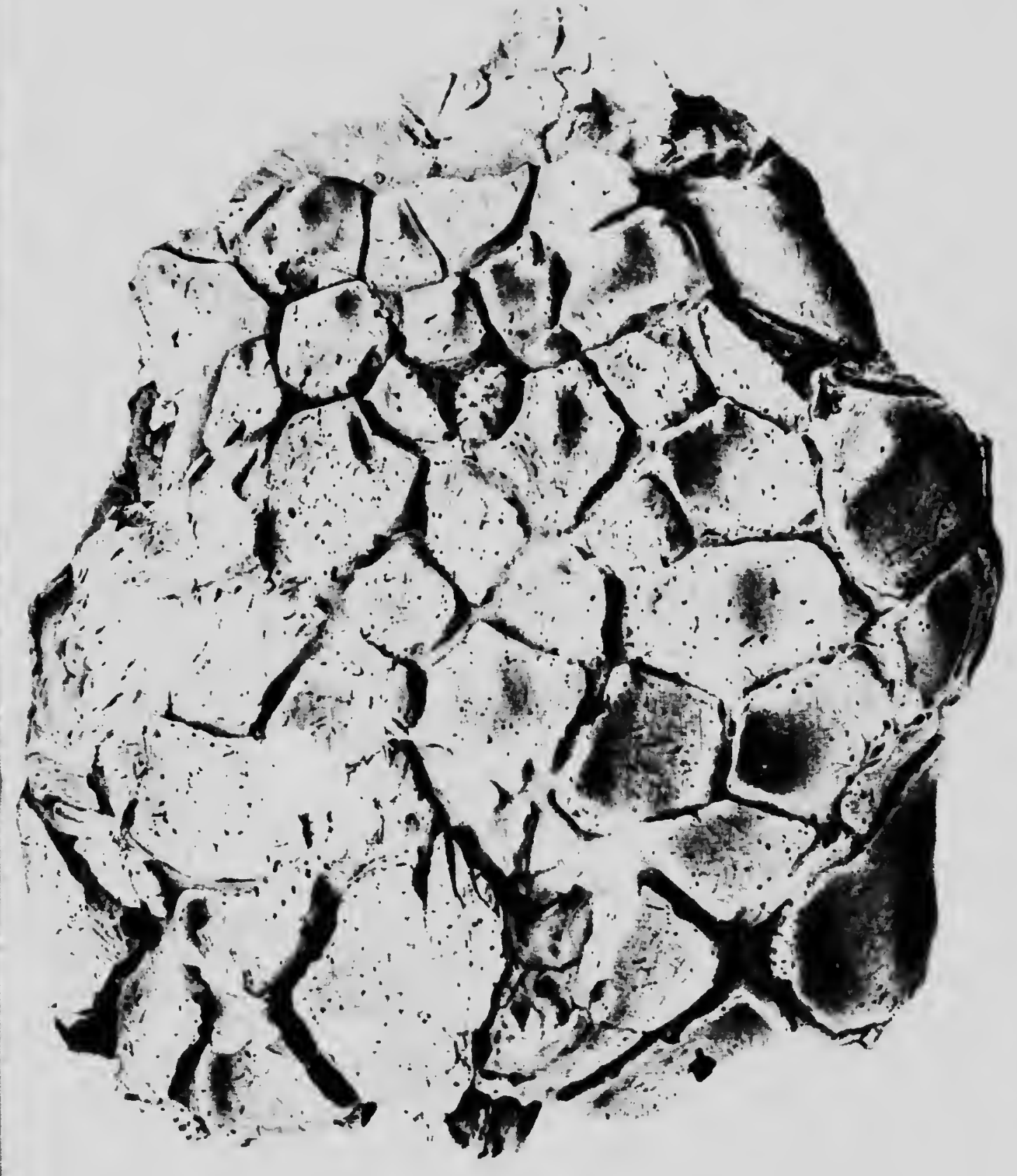


$d$

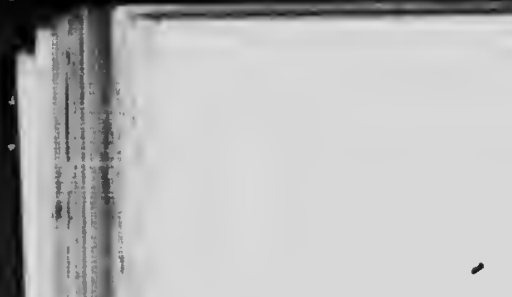



PLATF: XII.

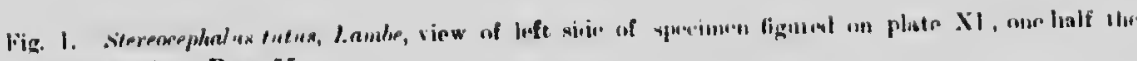
nalural sizo. Pngo th.

Fig. 2. Paintal view of the kane: one half the natural vige.

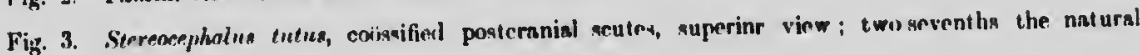
size. Page 56.

Fig. 4. The anine, nnterior view.

Fig. 5. Tranaverse section of rib (provivionally associatnl with S. Mtun): one-hnlf the natural size. Page 5.).

$p$, palatine ; $s$ suture ; $p t$, pterygoid ; $r$, interpterygnid vac uity ; $\gamma^{h}$, presphenoid and lasisphennir element; $a$, anterios ; $b$, posterior. 

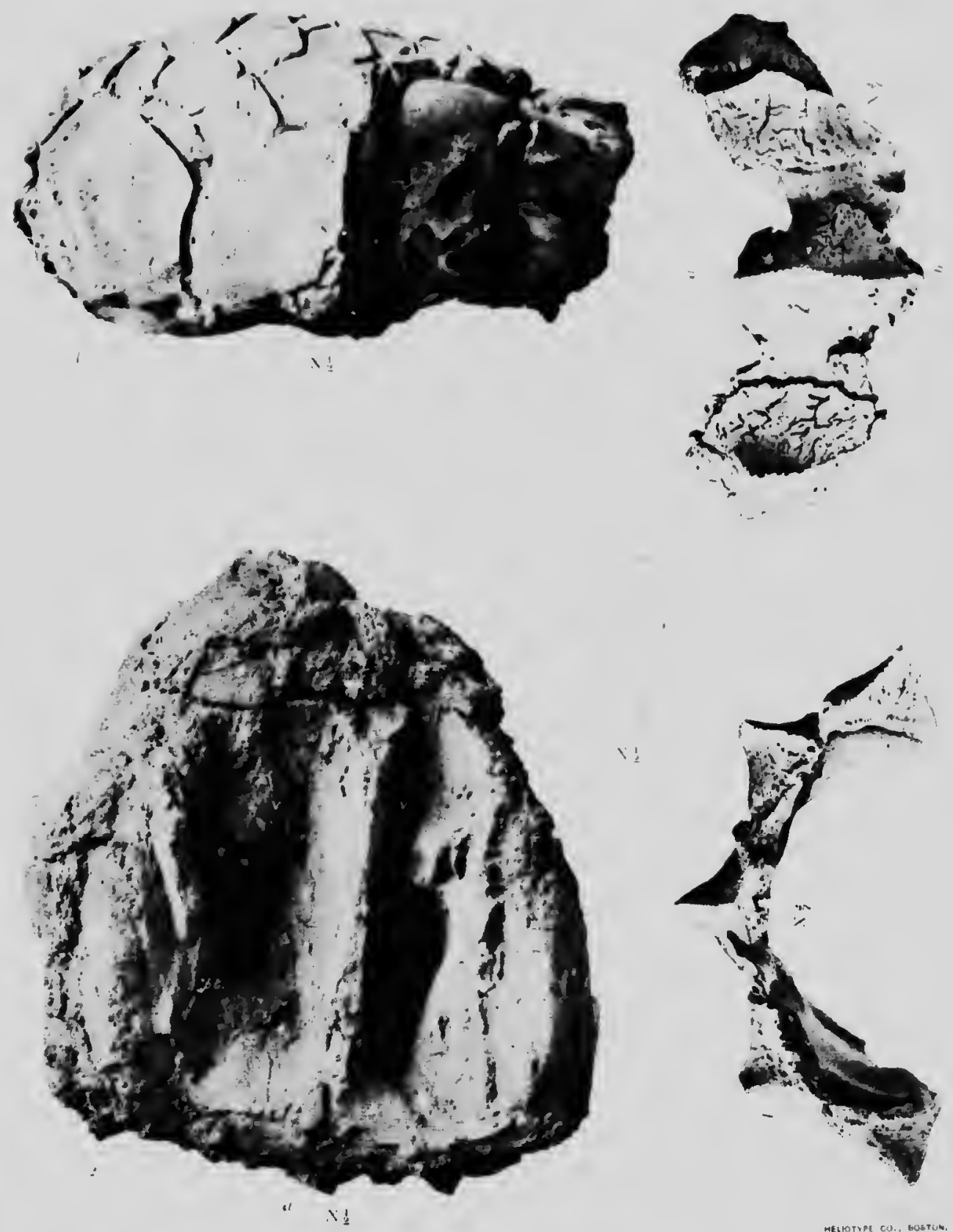


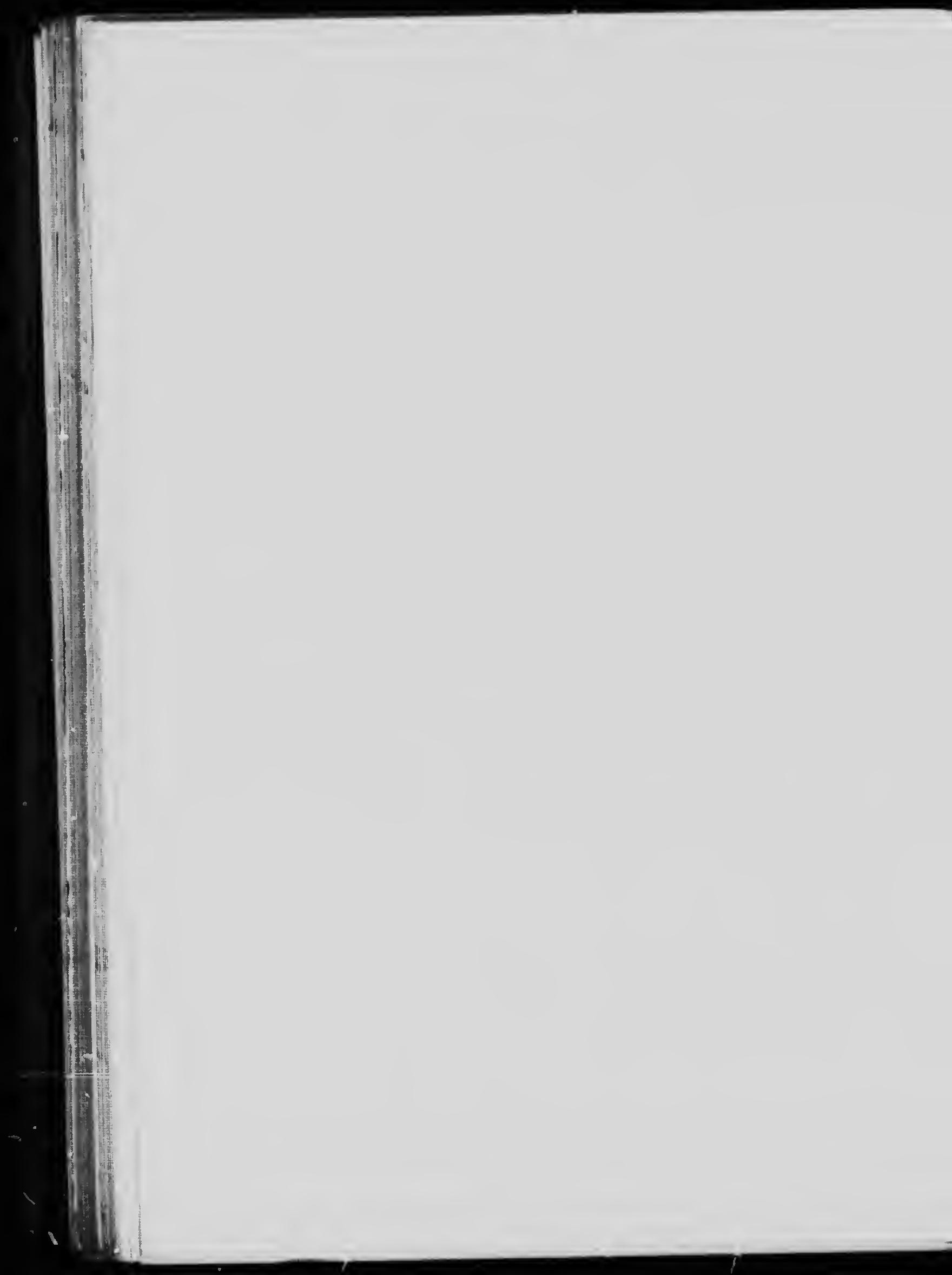



PL.ITE XIIL. 

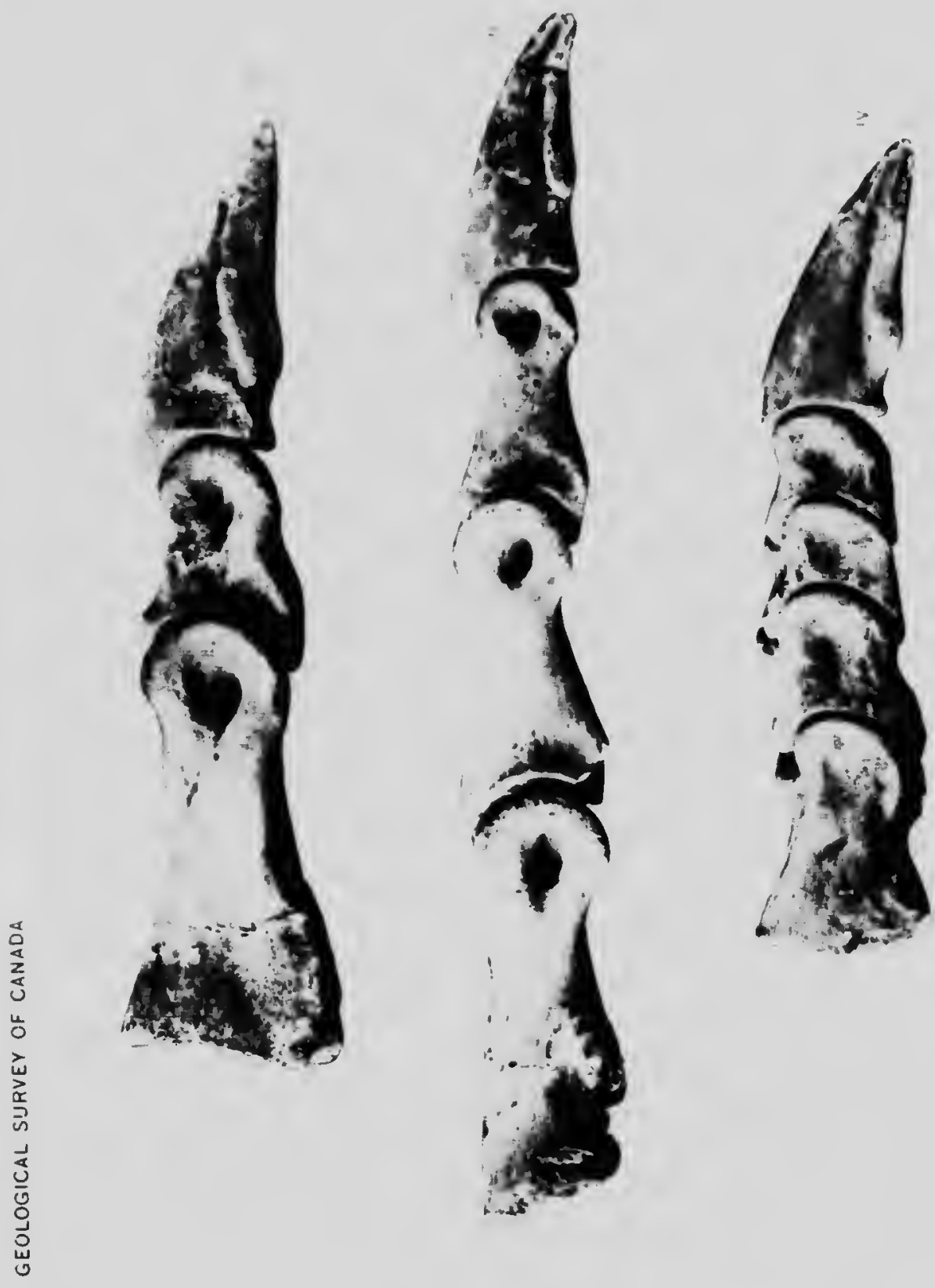


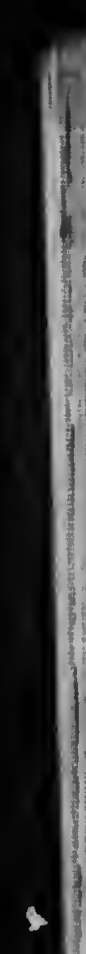


H'ATH XTV. 
PLATE: XIV

Ornithumimts d'tus, lamks.

Fig. 1. Pusterior dorsul vertedsan, viewsil frem the luft; natural sice. Pagw 50

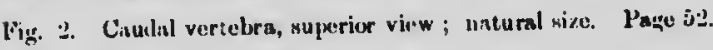

Fig. 3. The same, inferior view.

Fig. 4. The same, left lateral view.

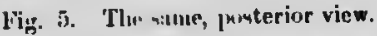

Fig. 6. I Histh end of metatarsal 11I. of left pes, viewed fruin the frunt; natural size. Page 50.

Fig. 7. Tlu: salue, posterior view.

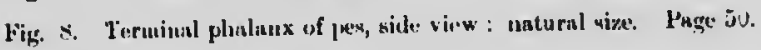

Fig. 9. The salle, pusterior view.

lig. IU. Tenuinal plualanx of manus, sido view : untural size. Page 53.

ligs. I1. The s:me. pmsterior view.

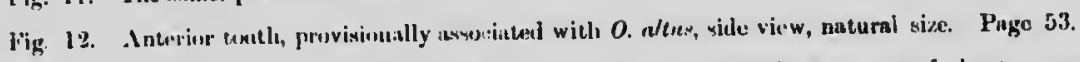

Fig. 13. l'usterior view of the sone, stowing tlu: minute denticulations on one of the two posterior curina:

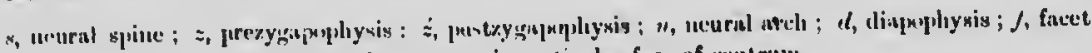

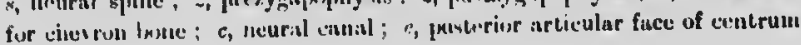


GEOLOGICAL SURVEY OF CANADA
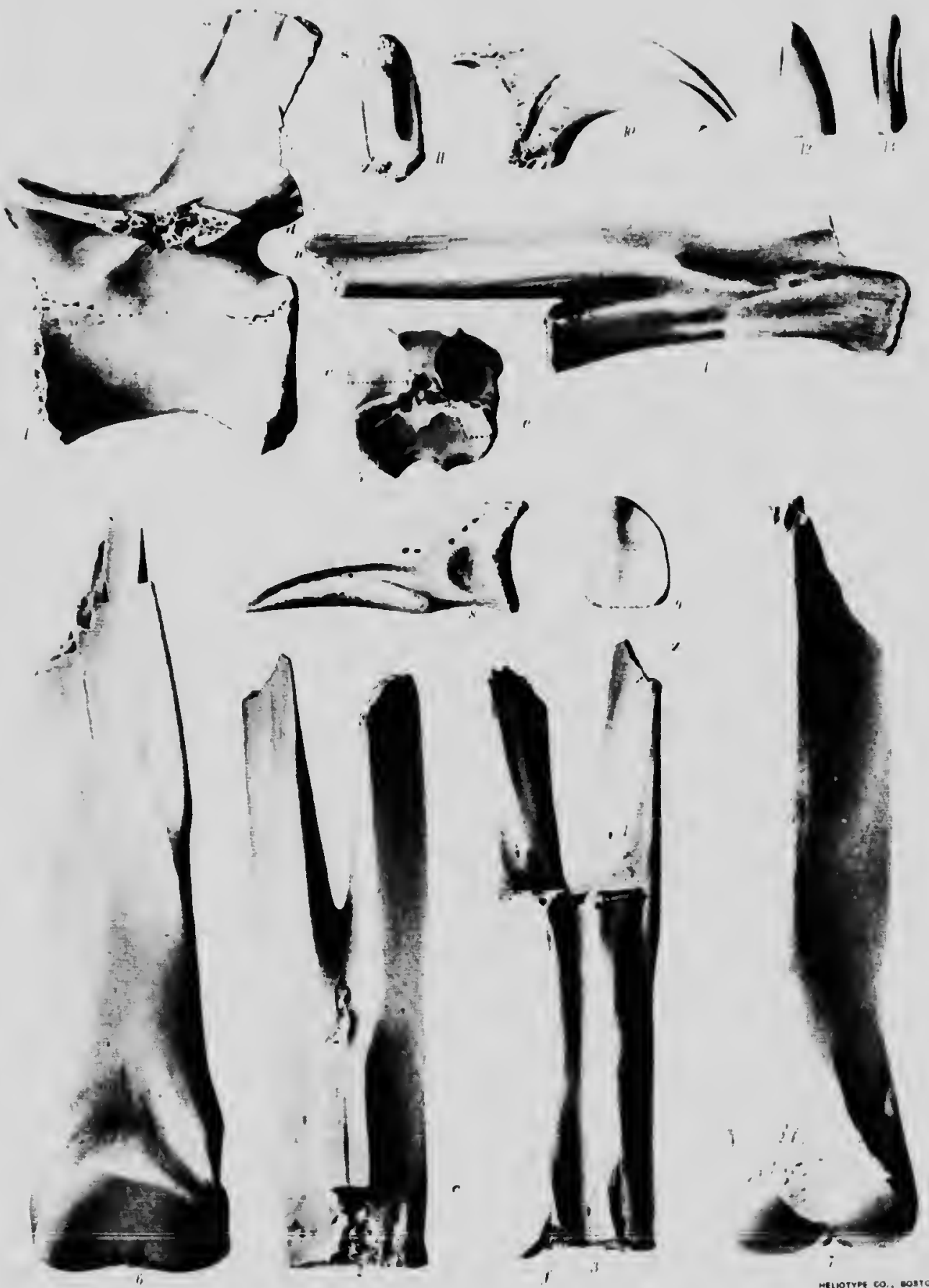


l'..ITH: . IV.

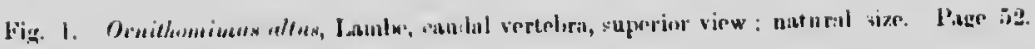

Fig. :. Vicw of right side of kanne.

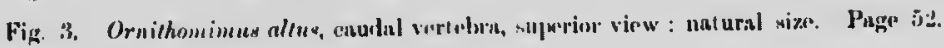

Fig. 1. The sunte, inforior view.

Fig. 3. The sane, right sille.

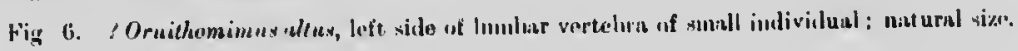

fig. 7 . The sanne, superior vien.

Fig. 8. The sane, unterior view.

Fig. 9. Termiual plalınx of meghiusnunid dinusiur, latornl view ; naturn! size.

Fig. 10. The simu, pruxiunal view.

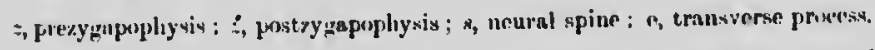

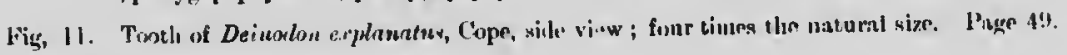

Fig. 12. In: 11sverse section of the same.

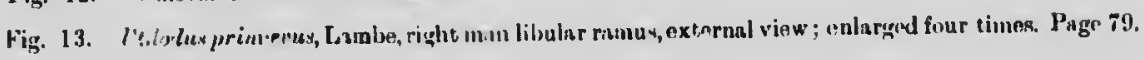

Fig. 14. The sume, internal vien.

$p I V$, fourth premolar; $m I$, first molitr; $i$, socket for incisor ; $u$, socket for seond molar.

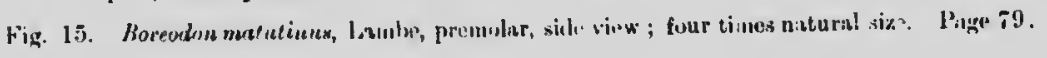

$r$, cinguluiı.

Fig. 16. lightit maxillary lxune, (provisionully associated with singherpeton trefum), externul view; four tiunes the natuinal sizc.

Fig. 17. Infrrior view of the snme, similanly enlargenl. Pnge 3!.

Fig. 18. Premaxillary bone of Diphyolus limgiroatris, Lunhe, inferior view; enlarged four times. 1". ge 30.

Fig. 19. Transverse section of snme, similnrly malargerl.

t, tonth.hase; nt, interspace. 


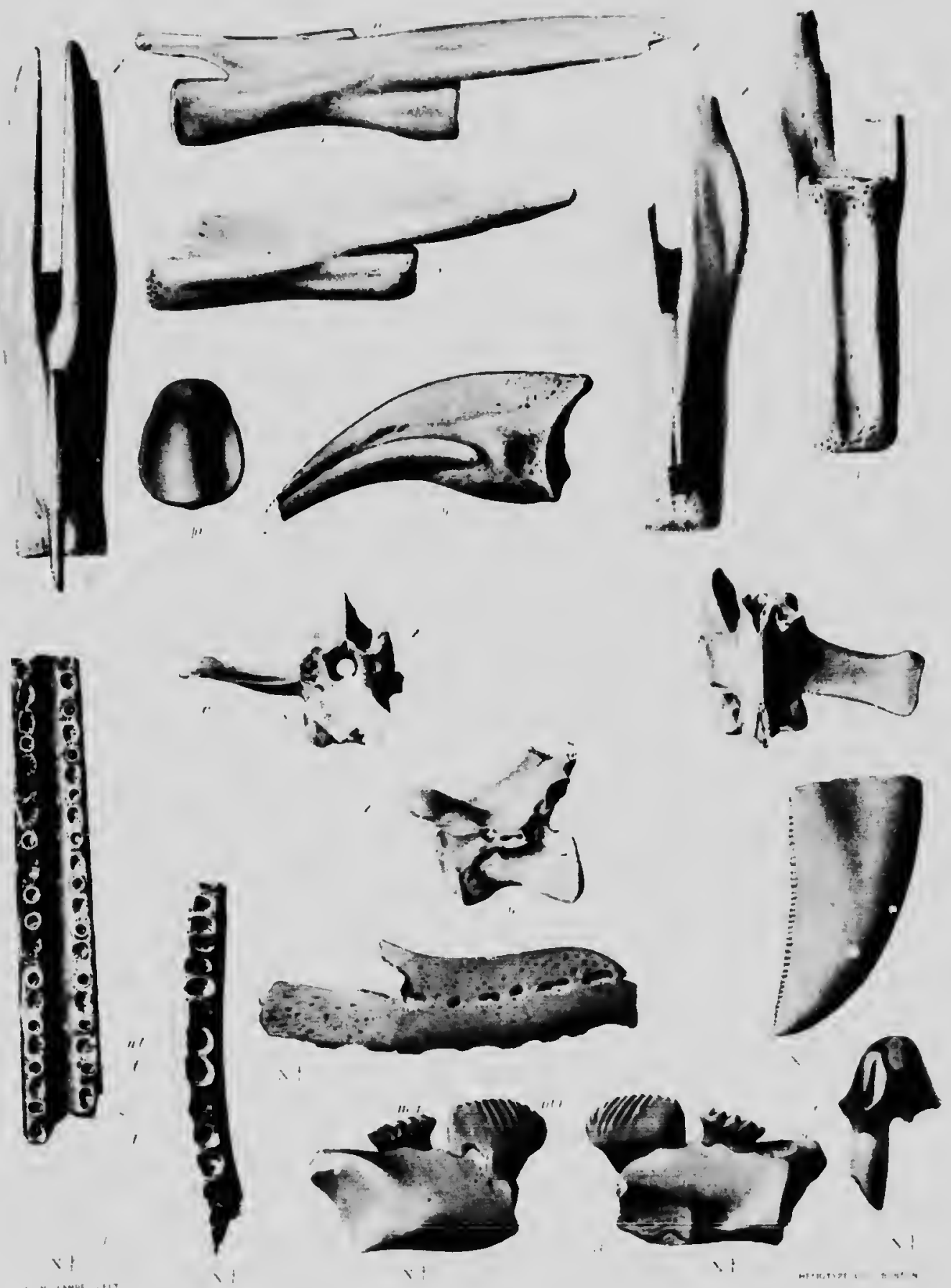




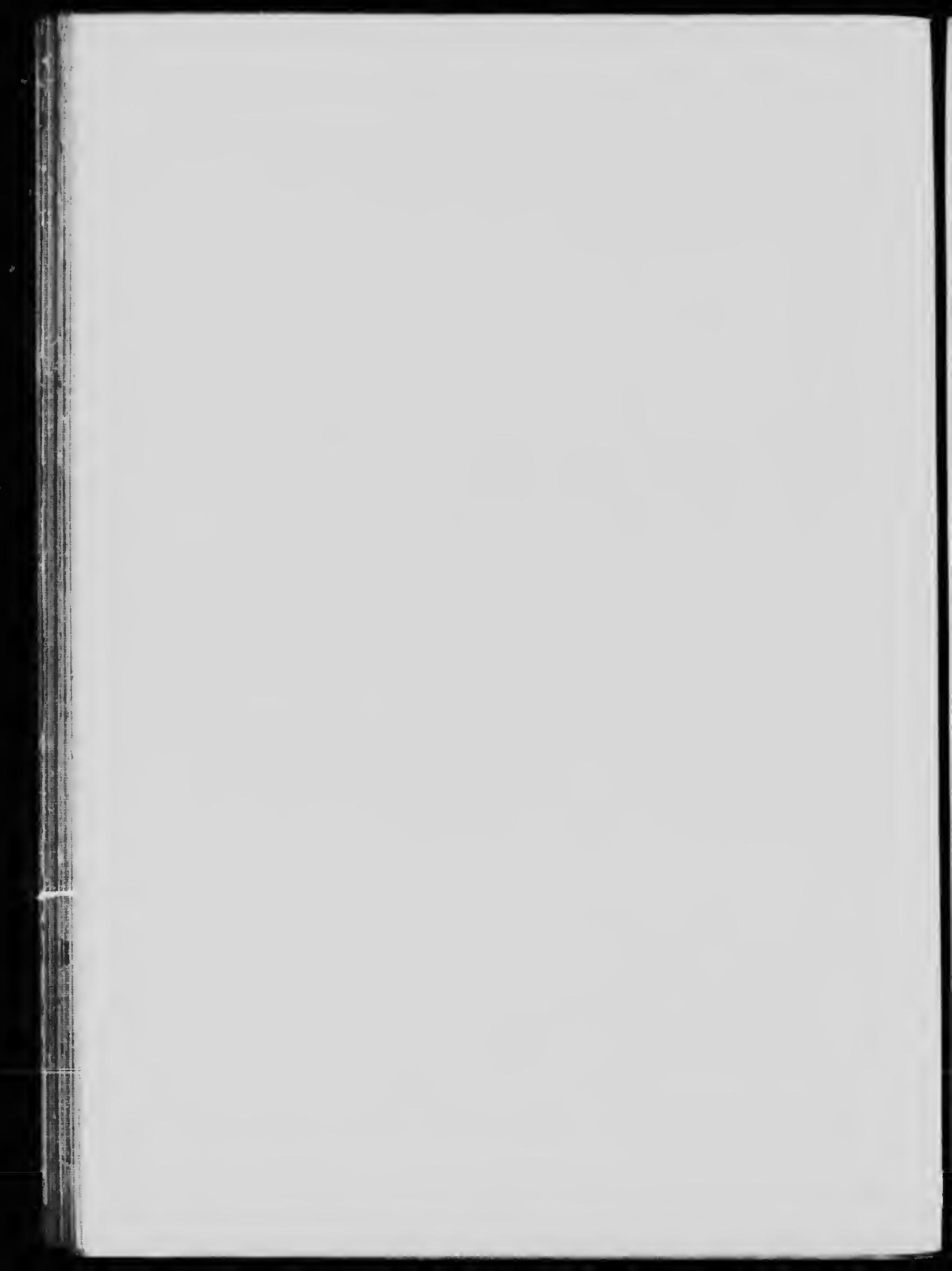



PI.ATE XVI.

Fig. I. Sacrum, provisionally associnted with Wonnclonius dawaoni, Labbe, superior view, two-sevenths the nat ural size. Paye 61 .

Fig. 2. The same, viewel from the right. 

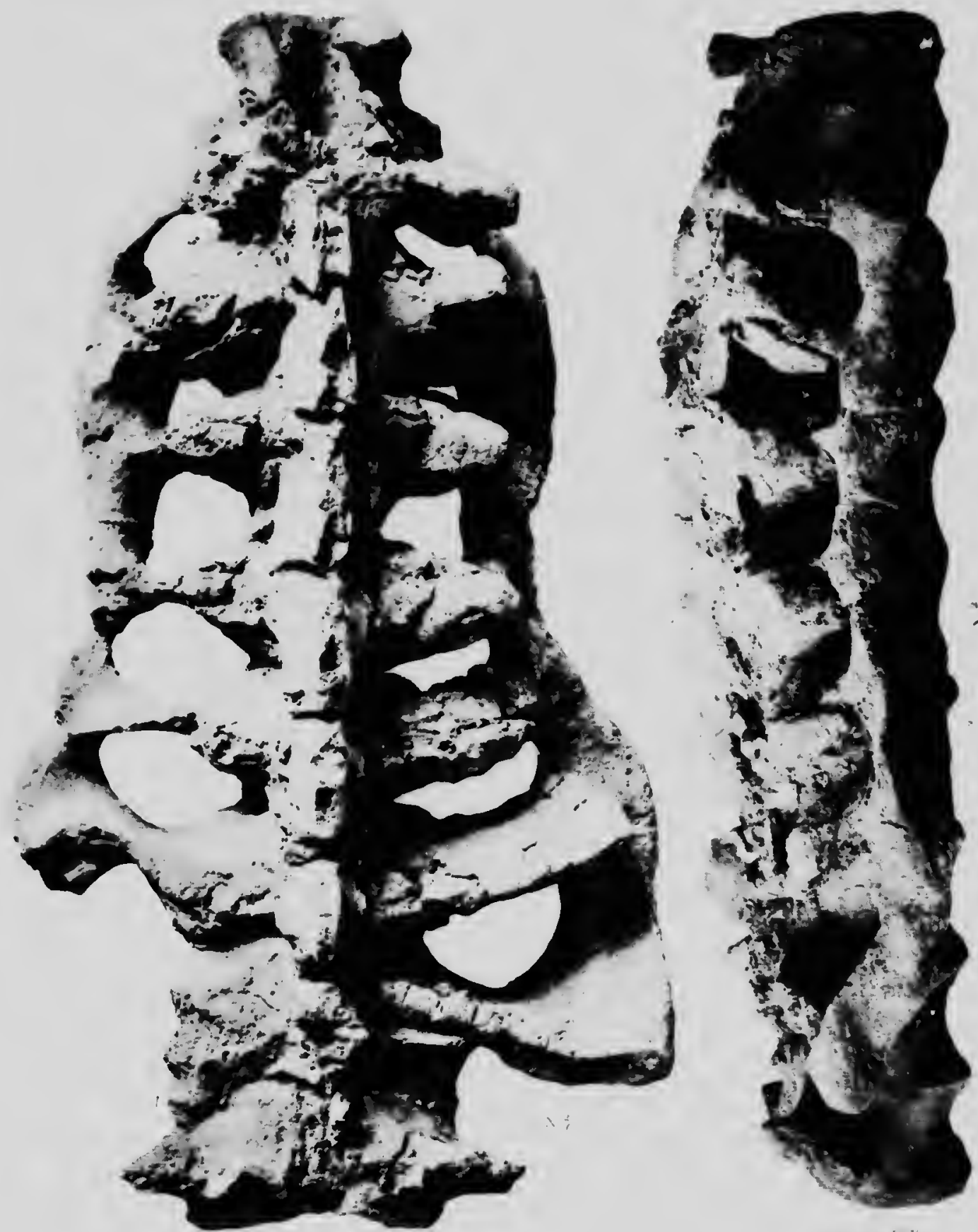
1

PLATE XVII. 


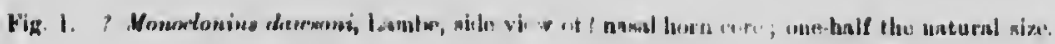

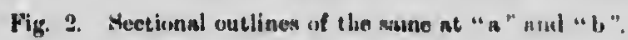

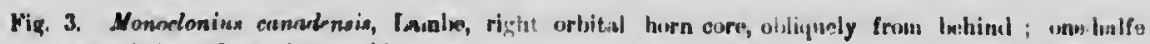
natural aize. Page 6is, o, orbit.

Fig. 4. The minn, murtional outline nt " $a$ ".

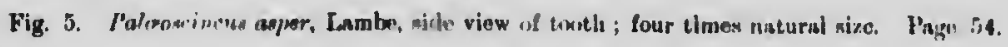




$$
8
$$




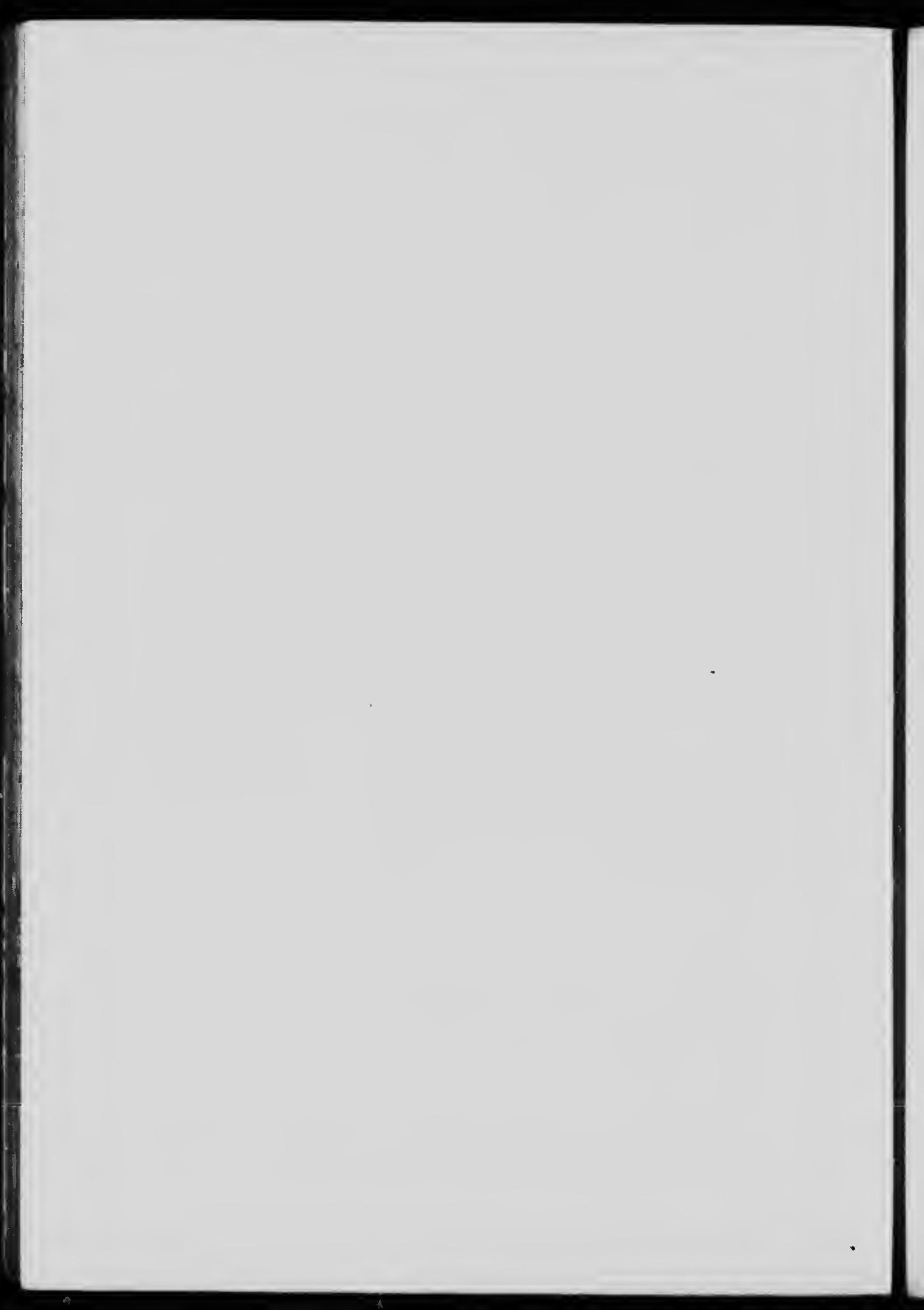





\section{PLATE IVIII.}

Fig. 1. Honoclonius canadnas, Lambe, right mandibular ramus, externul view ; one half the natural sizx. Page 6.5.

Fig. 2. The same, internal view.

Fig. 3. Monuslonin ennadensin, muxillary unth, oxternal view; untural size. (Provisioually mosciated with $M$. cunadnsis.) Page 66.

Fig. 4. Internal view nt the sume.

lig. 5. Tonth fmon lower jaw, (provisionally assa-iated with $\mathcal{V}$. canadensis), internal view ; natural size.

Fig. 6. The snmo, laterul view showing the two roots.

Fig. 7. The snine, exlernnal view.

e, comonoid procens ; $n$, hlveolar grouve; $b$, nyinphyseal surfawe; $c$, mandihular growe ; $f$ facet for prodentary bone. 

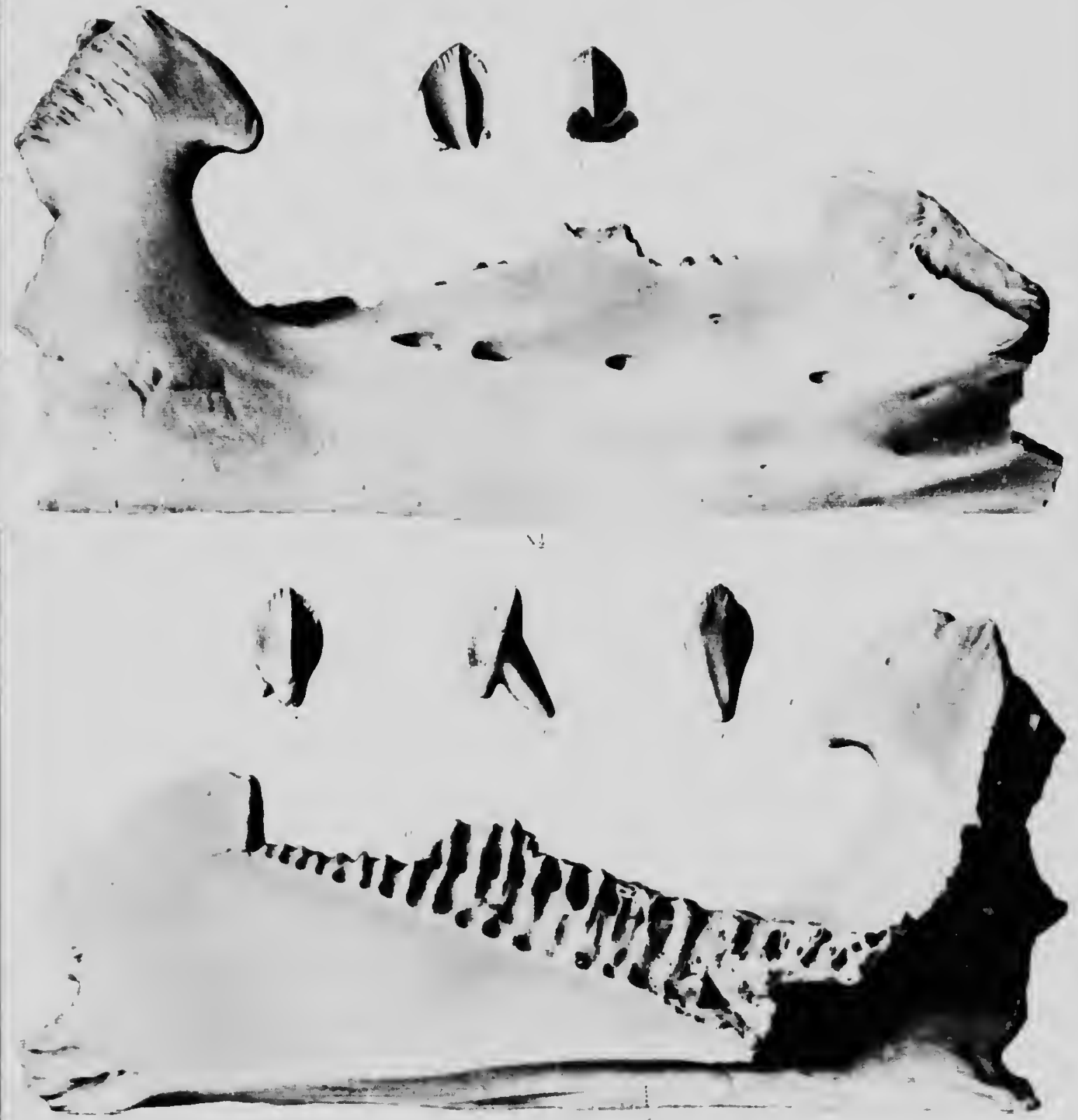
3
4 

PI.ATH: IIX.

Fig. 1. Myledhphus bigartitus, Cope, pavement tootl, face of crowu; enlarged four times. Page 2x.

Fig. 3. Side virw of anme tooth.

$g$, crown ; $f$, face of crown ; $r$, mot

Fig. 3. Lopialotus merilentalin, Laily, outer surface of menle; nntural size. L'age 29.

Fig. 4. Nomorloniud darmoni, Lambe, left scapula and corncoid, inturnal view. (P'rovisionally nsnociater) with $\boldsymbol{U}$. dewroni); one-fourth natural sive. Page 60

Fig. 5. Monoclonius dismoni, predentury bone, lateral view. (Provisionally axsociatel with $\boldsymbol{X}$. dauraoni); natural size. Page 63.

Fig. 6. The sanie, viewed from above.

4. scapula ; $e$, coracoid ; $a$, suture letween scapula and coracoid; $g$, glenoid cavity; $b$, upper borler; $d$, anterior end ; e, groove fur dentary. 


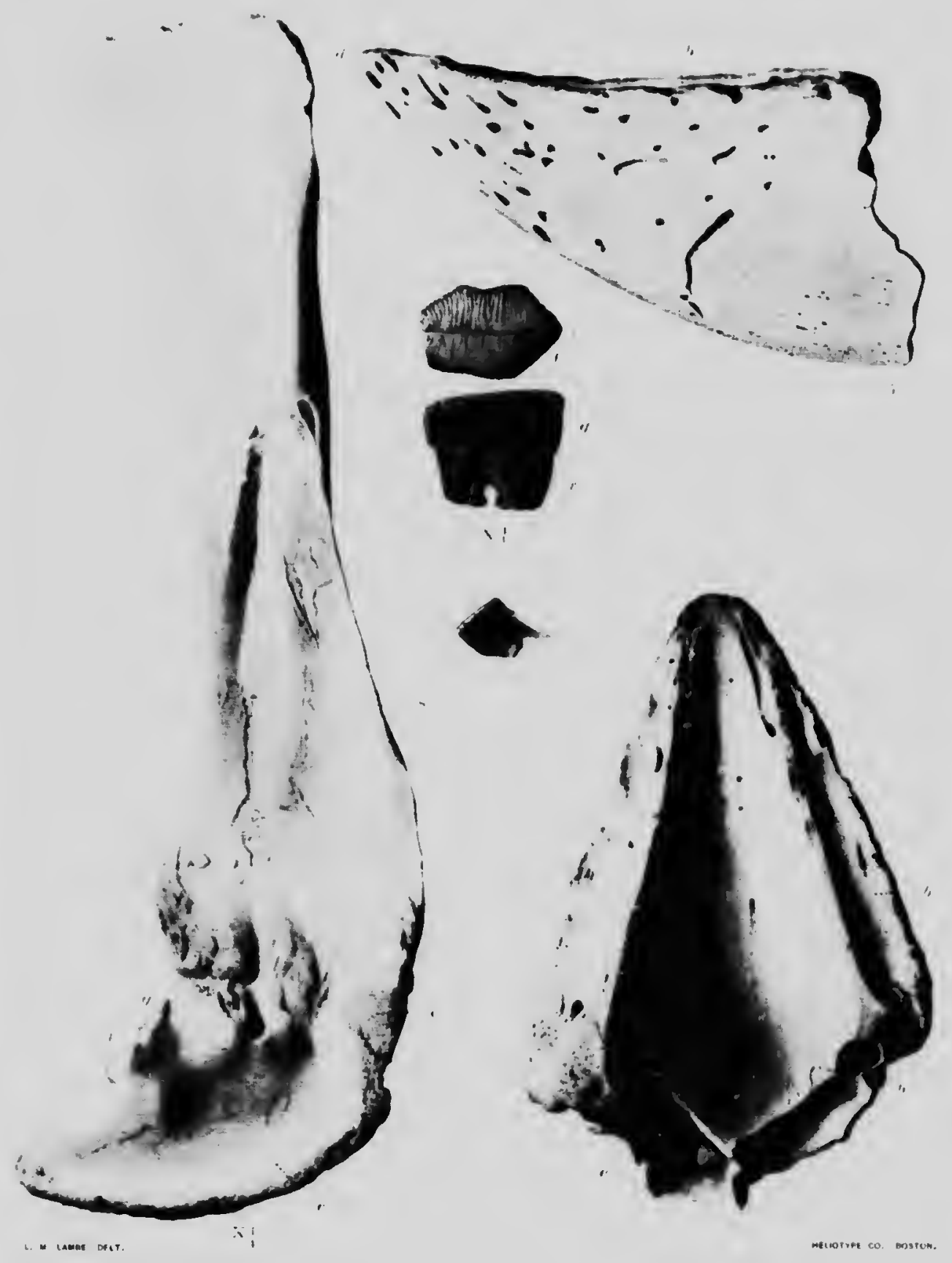



Pl.ATE $\mathrm{Xx}$.

Fig. 1. Sonodonima bolli, Lambe, pariotal elenuent of postericr creat, superior view; one-thinl th, natural sizo. Page 66.

Fig. 2. The sume, inferior view.

Fig. 3. Xonndoniun damoni, Lambe, rostrel bone, side view; ono-hall the natural wize. (Provision dly ansociated with 3 . daw'somi). Page 63.

Pig. 4. Outiine of rection of ame at "c."

Fig. 5. Horn core with an asymmetrical bane. Nut xpecificaliy dotermincrl.

Fig. 6. Sectional outlines of same at "a" and "L."

g. groove fur premaxilin 


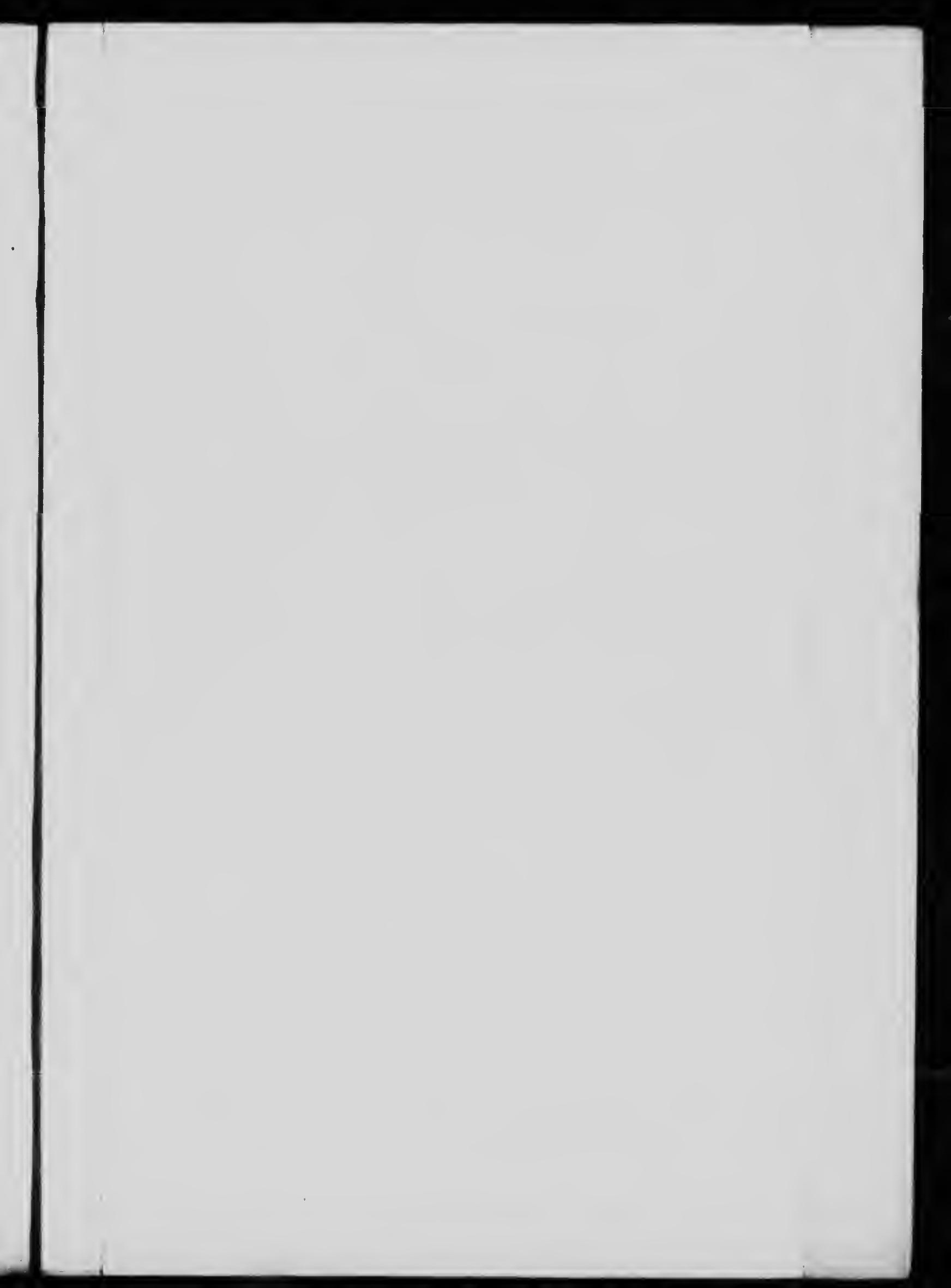




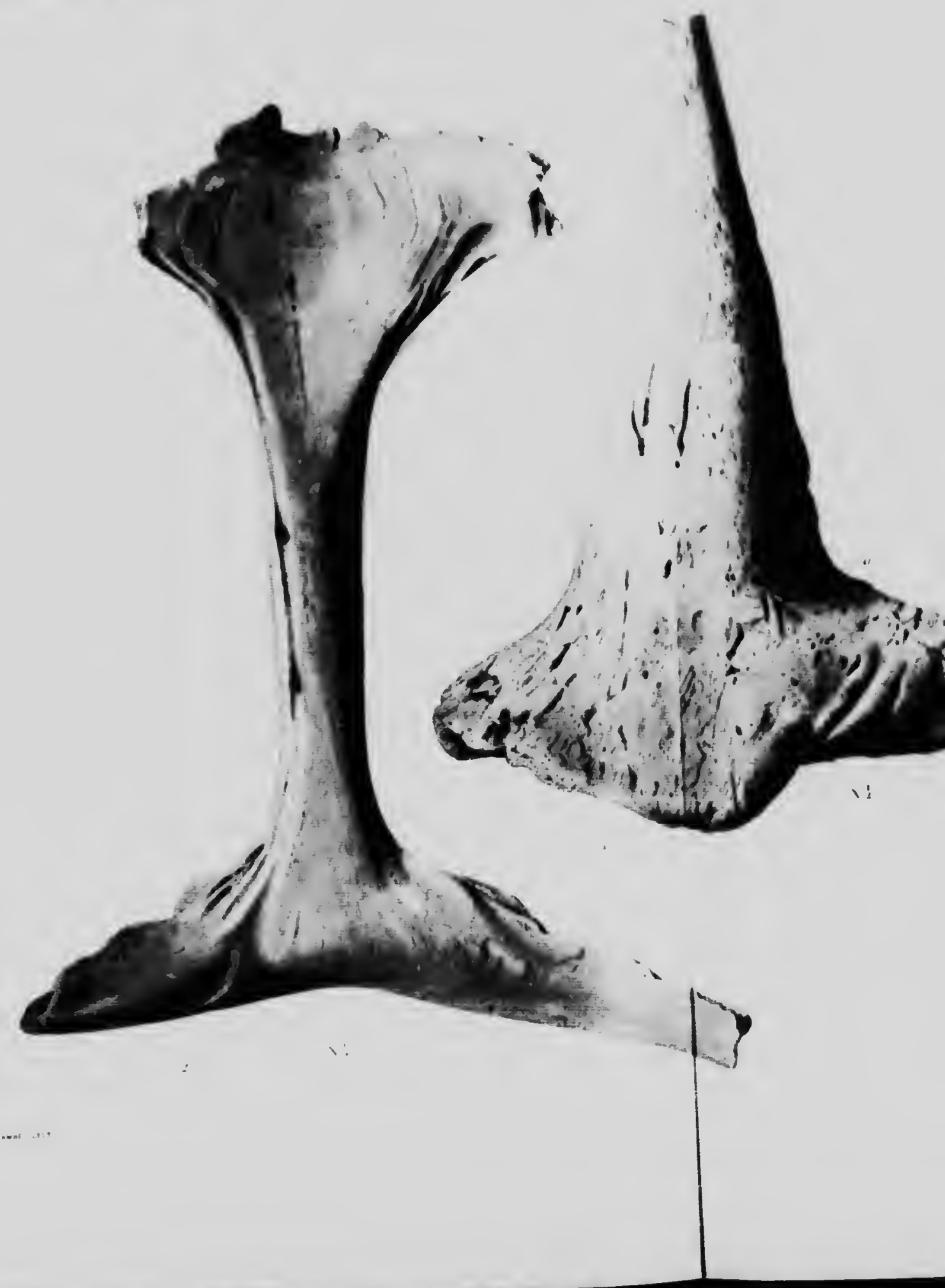




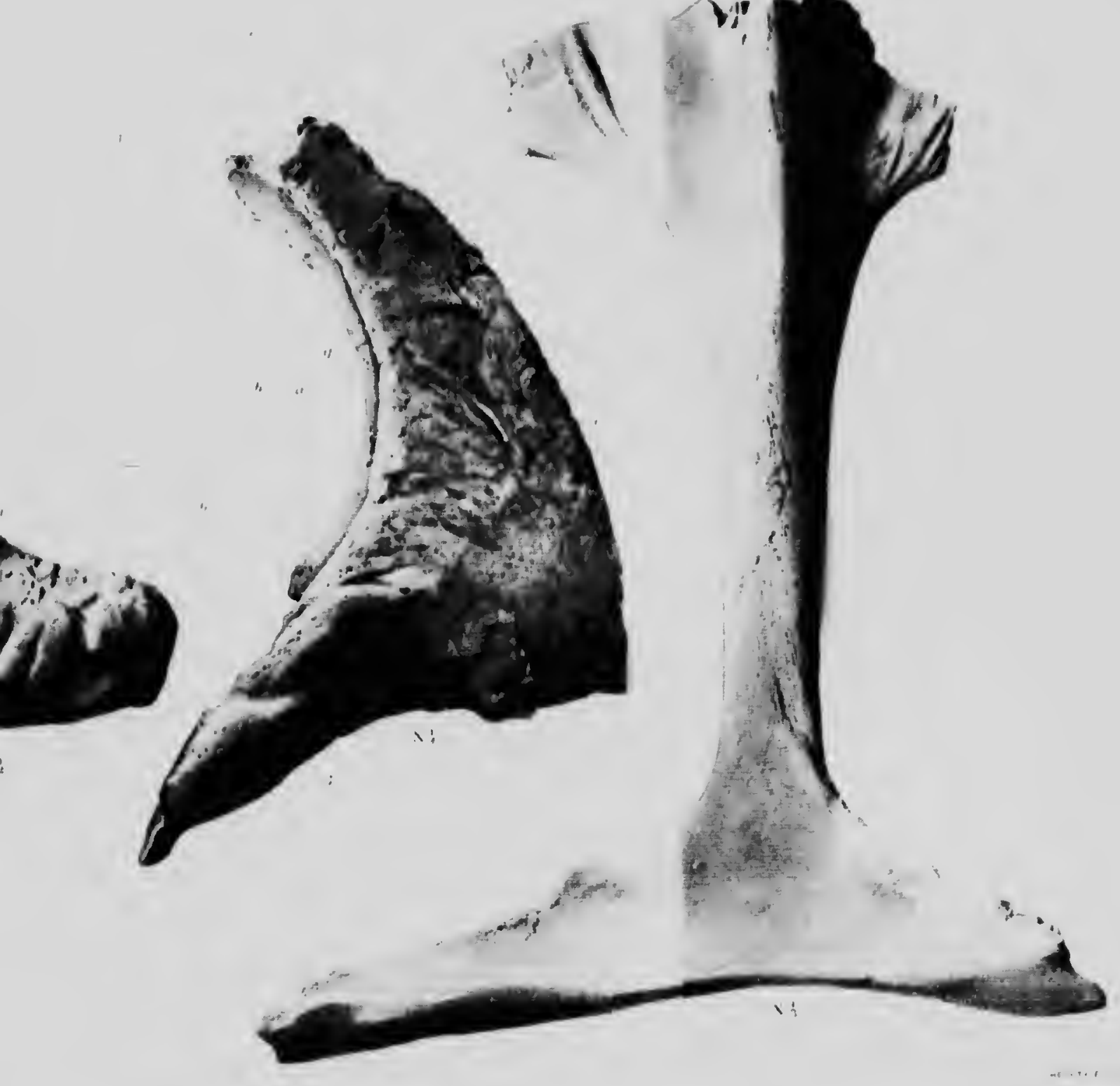




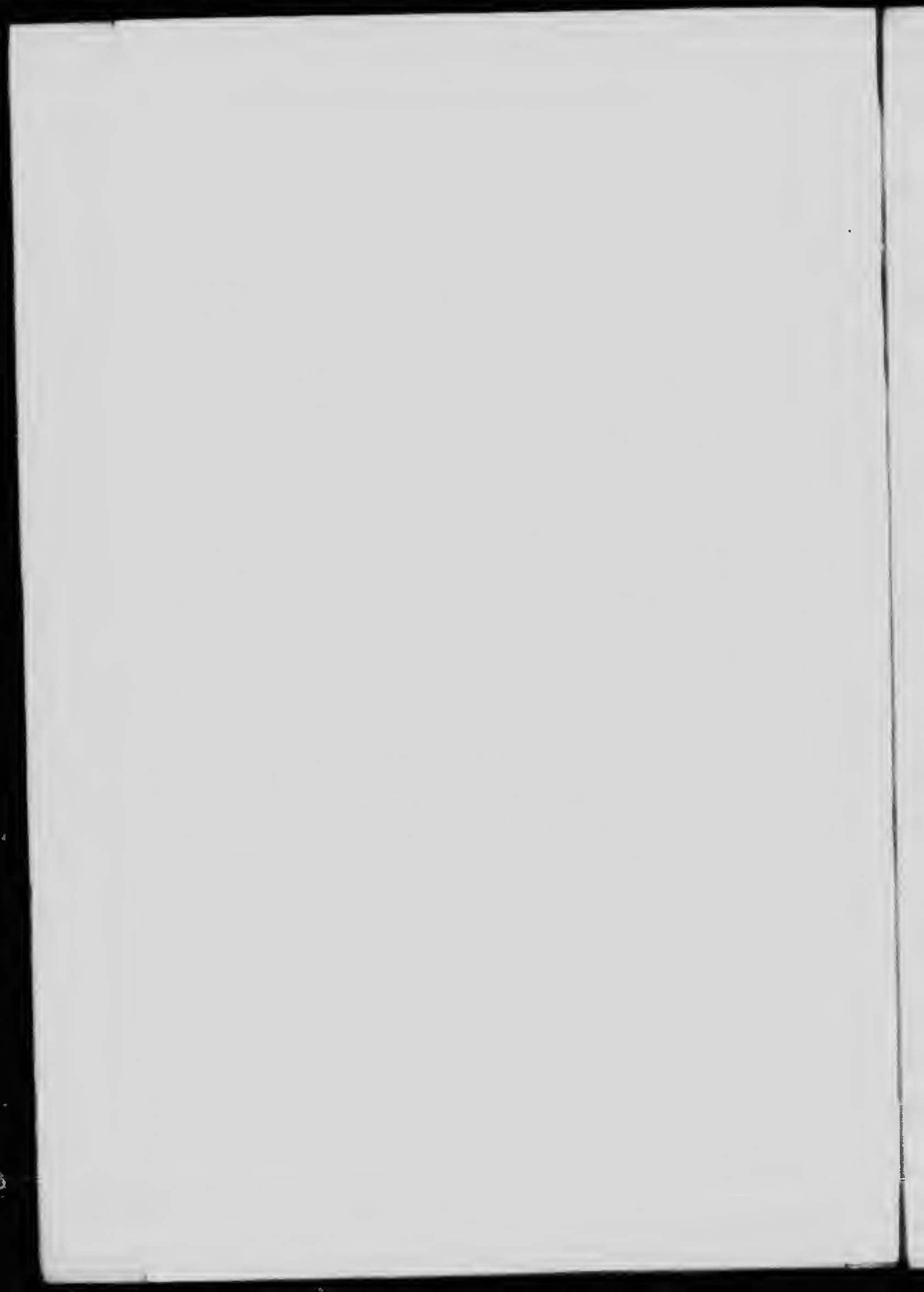


PLA'TE XXI. 
PLATE: INE.

Fig. 1. Stegrcerns colidus, Lambe, preanal bone ; side view. Natural vize. Puge 6*

Fig. 2. The same, inferior aspoct.

Fig. 3. Superior view of snother epecimen; natural size.

Fig. 4. The same; side view.

Fig. 3. The same; inferior view.

Fig. 6. Stereocephalua tutus, Lambe, symmetrical plate, superior mpect; ono-half the nat ural sise. (Pro. visionally anociated with $S$. Intuta).

Figa 7 and 8 . Similar keeled platas; one-hulf the natural size.

Fig. 9. Shield of Acipenser alberlenvia, Lambe, viewerl fnom alyve. Natural size. Page 29. 

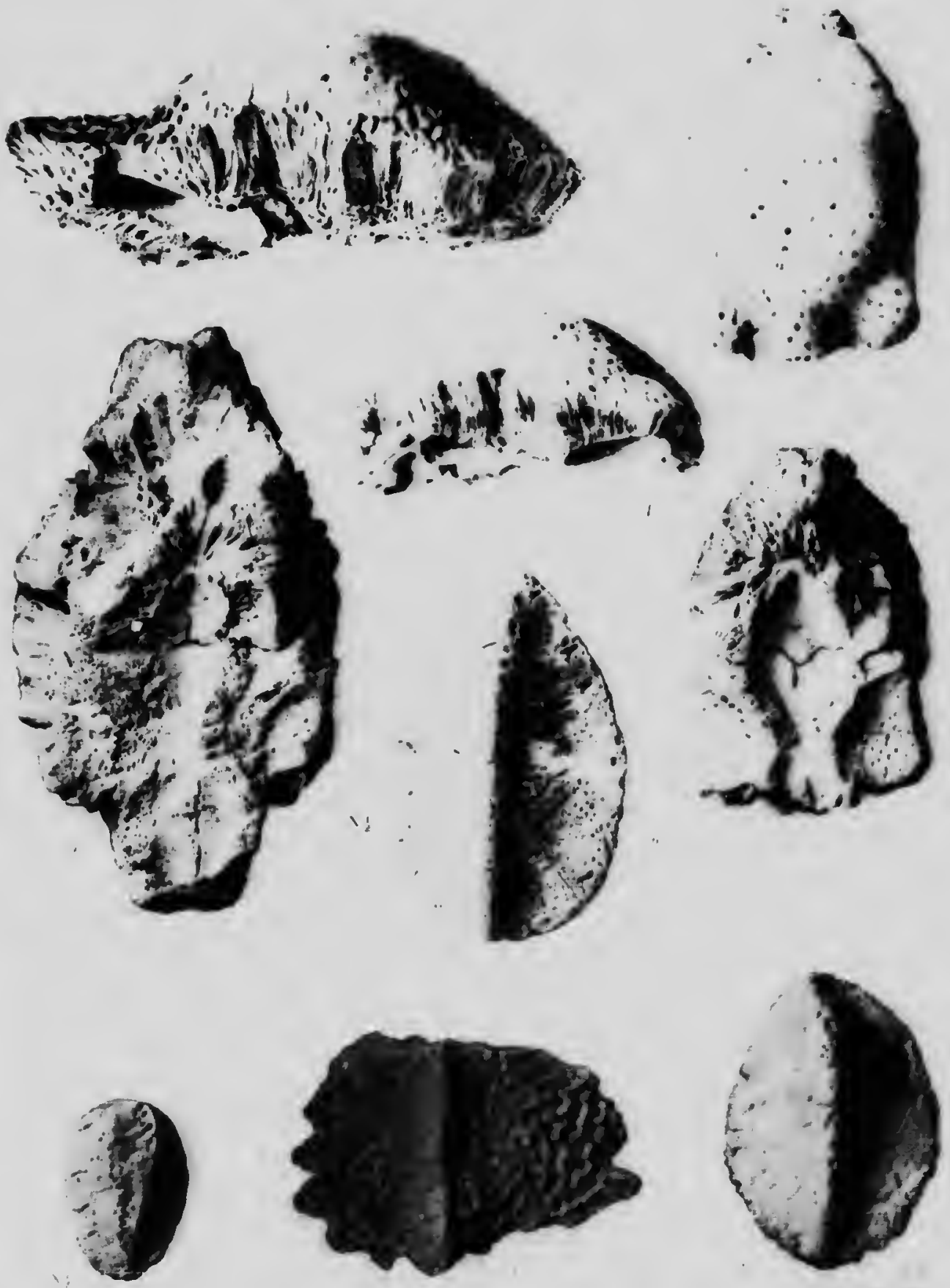
